\title{
BASELINE RISK ASSESSMENT OF Ground Water Contamination at the URANIUM MiLl TaILINGS Sites Near Rifle, Colorado
}

May 1995 


\section{INTENDED FOR PUBLIC RELEASE}

This report has been reproduced from the best available copy. Available in paper copy and microfiche.

Number of pages in this report: 256

DOE and DOE contractors can obtain copies of this report from:

Office of Scientific and Technical Information

P.O. Box 62

Oak Ridge, TN 37831

(615) $576-8401$

This report is publicly available from:

National Technical Information Service

Department of Commerce

5285 Port Royal Road

Springfield, VA 22161 .-

(703) $487-4650$

\section{DISCLAIMER}

This report was prepared as an account of work sponsored by an agency of the United States Government. Neither the United States Government nor any agency thereof, nor any of their employees, makes any warranty, express or implied, or assumes any legal liability or responsibility for the accuracy, completeness, or usefulness of any information, apparatus, product, or process disclosed, or represents that its use would not infringe privately owned rights. Reference herein to any specific commercial product, process, or service by trade name, trademark, manufacturer, or otherwise does not necessarily constitute or imply its endorsement, recommendation, or favoring by the United States Government or any agency thereof. The views and opinions of authors expressed berein do not necessarily state or reflect those of the United States Government or any agency thereof. 


\section{DISCLAIMER}

Portions of this document may be illegible in electronic image products. Images are produced from the best available original document. 
May 1995

Prepared for

U.S. Department of Energy UMTRA Project

Albuquerque, New Mexico

Prepared by

Jacobs Engineering Group Inc.

Albuquerque, New Mexico 


\section{CITIZENS' SUMMARY}

Human health risk may result from exposure to ground water contaminated from uranium ore processing. Exposure could occur from drinking water pumped out of a hypothetical well drilled in the areas of contamination. Environmental risk may result from plant or animal exposure to surface water and sediment that have received an inflow of contaminated ground water.

A risk assessment describes a source of contamination, how that contamination reaches people and the environment, the amount of contamination to which people or the environment may be exposed, and the health or environmental effects that could result from that exposure. This report is a site-specific document that will be used to evaluate current and future impacts to the public and the environment from exposure to contaminated ground water. The results of this evaluation and further site characterization will determine whether any action is needed to protect human health or the environment.

The U.S. Department of Energy (DOE) Uranium Mill Tailings Remedial Action (UMTRA) Project consists of the Surface Project (Phase I) and the Ground Water Project (Phase II). Under the UMTRA Surface Project, tailings, radioactive contaminated soil, equipment, and materials associated with the former processing of uranium ore at UMTRA sites are placed into disposal cells. The cells are designed to reduce radon and other radiation emissions and to prevent further contamination of ground water. Two UMTRA Project sites are near Rifle, Colorado: the Old Rifle site and the New Rifle site. Surface cleanup at these two sites is under way and is scheduled for completion in 1995. The Ground Water Project evaluates the nature and extent of ground water contamination resulting from the uranium ore processing activities.

\section{RISK SUMMARY}

Currently, no one is using the ground water to drink or bathe in at or adjacent to either Rifle site. Therefore, no risk is associated with exposure from these pathways. This situation will continue if land and water use near the sites does not change (e.g., a residential drinking water source is constructed in the contaminant plume). Additionally, the concentration of contaminants to which people could be exposed due to potential current exposure pathways (skin contact with surface water and sediment, and fish ingestion) is not expected to cause adverse health effects. Current evaluation of limited environmental data suggests that the Old Rifle pond environment potentially could adversely affect aquatic organisms.

Because the land at and downgradient of the Old and New Rifle sites probably will be developed, this risk assessment examines the future possibility of people drinking the contaminated ground water and evaluates potential health problems. Certain health jroblems could occur if a drinking water well is placed in the contaminated ground water at either the Old or the New Rifle site; therefore, people should not drink the contaminated ground water in the future.

If the concentrations of contaminants from other exposure pathways (skin contact with ground water, surface water, and sediment, and fish ingestion) are added to the drinking 
water pathway, the exposure concentrations will not substantially increase the potential for adverse health effects. Evaluation of the ecological conditions for the planned mitigation wetlands at the New Rifle site indicates a potential for adverse effects to occur to aquatic life and to terrestrial wildlife and plants.

\section{GROUND WATER QUALITY AND USES}

\section{Background ground water quality}

Background ground water quality is the natural quality of water in the area, not affected by uranium milling activities. There are two water-producing units, or aquifers, in the immediate vicinity of the Rifle sites: a shallow aquifer (the alluvium) and a deeper aquifer (Wasatch Formation).

In the Rifle area, ground water from the alluvium and the Wasatch Formation is naturally poor tasting and considered undrinkable due to its high content of sulfates and total dissolved solids. Neither aquifer supplies municipal water because the ground water would need extensive treatment before it could be consumed. Water for the Rifle residents comes from the Colorado River and Bear Creek, away from any contamination associated with the UMTRA sites. People outside the city of Rifle use ground water for purposes other than drinking, such as bathing and irrigating. Private well users drink bottled water or use Rifle's municipal water supply system.

\section{Site-related ground water quality}

When uranium mill tailings were in place at the two sites (from 1924 to 1995 for Old Rifle and from 1958 to 1995 for New Rifle), rainwater and the overland flow of surface water moved through the tailings, picking up contaminants as the water moved downward toward the ground water. As a result, part of the shallow and deep aquifers beneath the Rifle sites became contaminated. Ground water at New Rifle flows back and forth between the two aquifers, mixing the ground water. The contamination also appears to extend west, some distance off the site; however, the full extent of contamination has not been determined. Intermixing of the two aquifers at Old Rifle has not been studied extensively enough to draw any definite conclusions; based on what is known, however, a large downward movement of contaminants is not expected. The contaminated alluvial ground water at Old Rifle has not moved very far from the site.

One private industrial well is almost 3 miles from the New Rifle site in the direction in which the contaminated ground water moves. The source of the chemicals detected in this well has not been determined and needs further study. Employees at this industrial site are not exposed to the chemicals in the ground water; they drink bottled water because the ground water tastes bad. Due to the manner in which the ground water flows at the Old and New Rifle sites, the former uranium mill activities affect none of the other existing private wells in the area.

Contaminants detected in the ground water that could cause adverse human health effects if taken into the body are called contaminants of potential concern. Ammonium, antimony, arsenic, cadmium, chloride, fluoride, iron, lead, manganese, molybdenum, selenium, 
sodium, sulfate, vanadium, uranium, lead-210, polonium-210, radium-226, and thorium-230 are the contaminants of potential concern detected in the shallow aquifer at New Rifle. Except for cadmium, lead, and nitrate, the contaminants of potential concern detected in the Wasatch Formation at New Rifle are the same as those in the alluvium at New Rifle.

Arsenic, fluoride, iron, manganese, molybdenum, selenium, sulfate, vanadium, uranium, lead-210, polonium-210, radium-226, and thorium-230 are the contaminants of potential concern in the shallow aquifer at Old Rifle.

Ground water beneath the Rifle sites flows into several surface water bodies. When contaminated ground water feeds a surface water body, the contaminated ground water can contaminate the surface water. Likewise, the surface water can come into contact with the sediment and contaminate it. Therefore, this report also evaluates the possible effects of contaminated ground water on the surface water bodies at the Rifle sites. The contaminants of potential concern for human health for surface water and sediment were assumed to be the same as those for ground water.

\section{HUMAN HEALTH RISK ASSESSMENT}

\section{Methods}

The risk assessment first identifies ground water contaminants resulting from uranium ore processing. This is done by comparing water quality data from wells drilled on the site and from background wells. This ground water analysis probably will overestimate the potential risk because the comparison uses ground water from the most contaminated part of the alluvial aquifers. The next step examines possible human health problems from exposure to contaminated ground water. A person in the Rifle sites area could be exposed to contaminated ground water by drinking ground water; accidentally drinking surface water while swimming; contacting his/her skin with ground water, surface water, and sediment; eating fish caught from the Old Rifle pond; and accidentally eating sediment (e.g., a child eating sediment while playing at a pond). Of all potential exposures evaluated, drinking the contaminated ground water was determined to be the greatest concern. Therefore, this exposure route is evaluated in detail.

This risk assessment considers possible current and future ground water uses. Based on a water use survey in the Rifle sites area, no one currently uses the contaminated ground water. However, ground water could be used for drinking water in the future. To evaluate future risks, it was assumed that people get all their drinking water from a residential drinking water well constructed in the most contaminated area under the site.

Health risks are evaluated for the age group most likely to experience health problems from the contamination. Children (aged 1 to 10 years) are the most likely to be affected by drinking contaminated ground water because their bodies are small and they tend to drink a lot of water. Infants (aged 0 to 1 year) are especially sensitive to contaminants like sulfate. Cancer is one health problem that takes a long time to develop; therefore, cancer risks are evaluated for adults $(11+$ years). 
The seriousness of health effects varies for several reasons. The levels of contaminants in ground water vary from one well sampling round to the next. People vary in their body weight, the amount of water they drink each day, and their bodies' reaction to chemical exposures. This risk assessment consiclers these differences whenever possible.

The risk assessment provides graphs showing the various exposure levels that might occur and the most current scientific information on the health effects that could result from the hypothetical exposure.

\section{Results}

Possible future health risks are associated with drinking the ground water at the Old and New Rifle sites. Table CS-1 summarizes the nature of these health problems. Note that only people who drink all their water from the hypothetical well will experience the health problems listed in Table CS-1. Therefore, the table presents the upper limit of possible risks; real risks probably would be lower.

\section{New Rifle}

Several contaminants of potential concern detected in ground water at New Rifle could cause adverse health effects if taken into the body. Severe health effects could develop due to the water's ammonia, arsenic, iron, manganese, nitrate, and sulfate content. Nitrate and sulfate would affect infants in particular. Sulfate exposure could cause severe diarrhea, quickly leading to dehydration. Nitrate exposure could cause a condition called methemoglobinemia, where the oxygen availability in the blood stream decreases, eventually causing unconsciousness. Ammonium exposure could cause mild to severe digestive tract and kidney problems. Manganese exposure could cause memory loss, irritability, and muscle rigidity. Arsenic exposure could cause liver, artery, and skin adverse effects. Long-term iron exposure could lead to cirrhosis of the liver. Uranium and arsenic exposures could increase the incidence of cancer.

The remaining contaminants of potential concern at New Rifle also could pose health problems. Fluoride exposure could result in dental damage (mottling) in children. Exposure to molybdenum could result in copper deficiency leading to anemia, and the sodium chloride levels could lead to high blood pressure. Vanadium exposure could cause sudden drops in cholesterol levels. A distinguishing feature of vanadium exposure is the development of a green tongue. Adverse selenium effects could result in brittleness and loss of nails and hair.

\section{Old Rifle}

The most significant adverse health effects that contaminants of potential concern could cause at Old Rifle are severe diarrhea, leading to dehydration in infants, from sulfate exposure. Uranium and arsenic exposures could increase the incidence of cancer. Milder effects could be seen from fluoride, manganese, and molybdenum. Manganese exposure could cause neurological symptoms such as memory loss, irritability, and muscle rigidity. Fluoride exposure could result in dental damage (mottling) in children, and molybdenum exposure could result in a copper deficiency, leading to anemia. 
Table CS-1 Potential adverse human health effects of drinking contaminated ground water, Rifle, Colorado, sites

\begin{tabular}{|c|c|}
\hline $\begin{array}{l}\text { Contaminant of } \\
\text { potential } \\
\text { concern }\end{array}$ & Potential health problems \\
\hline Arsenic & $\begin{array}{l}\text { Mild to severe toxicity including neurological effects, cirrhosis of the } \\
\text { liver, thickening of the arteries, and skin discoloration. Individual excess } \\
\text { lifetime cancer risk above the acceptable EPA risk range (skin cancer). }\end{array}$ \\
\hline Ammonium & Mild to severe toxicity to the digestive tract and kidneys. \\
\hline Antimony & Adverse effects not expected to occur. \\
\hline Cadmium & Adverse toxic effects not expected to occur. \\
\hline Fluoride & Mild effects following long-term exposure: dental damage (mottling). \\
\hline Iron & $\begin{array}{l}\text { Mild to severe effects following long-term exposure: ranging from iron } \\
\text { buildup in body organs and skin discoloration to cirrhosis of the liver. }\end{array}$ \\
\hline Lead & $\begin{array}{l}\text { Neurobehavorial toxicity and effects on the blood are known to occur } \\
\text { with lead exposure, but no safe level has been demonstrated. }\end{array}$ \\
\hline Manganese & $\begin{array}{l}\text { Mild to severe effects following long-term exposure: neurological } \\
\text { symptoms such as memory loss, irritability, and muscle rigidity. }\end{array}$ \\
\hline Molybdenum & $\begin{array}{l}\text { Mild to severe effects following long-term exposure: copper deficiency } \\
\text { anemia. }\end{array}$ \\
\hline Nitrate & $\begin{array}{l}\text { Short-term effects ranging from mild to severe: weakness, rapid pulse } \\
\text { and breathing, and methemoglobinemia. }\end{array}$ \\
\hline Selenium & Mild toxic effects: nail and hair brittleness and loss. \\
\hline $\begin{array}{l}\text { Sodium and } \\
\text { Chloride }\end{array}$ & Hypertension following long-term exposure. \\
\hline Sulfate & Short-term mild to severe effects: diarrhea leading to dehydration. \\
\hline Uranium & $\begin{array}{l}\text { Health problems not predictable from chemical toxicity; individual } \\
\text { excess lifetime cancer risk above the acceptable EPA risk range. }\end{array}$ \\
\hline Vanadium & $\begin{array}{l}\text { Mild effects: sudden drops of cholesterol levels, loosened stools and } \\
\text { cramps, and green tongue. }\end{array}$ \\
\hline $\begin{array}{l}\text { Lead-210, } \\
\text { polonium-210, } \\
\text { radium-226, } \\
\text { thorium-230 }\end{array}$ & $\begin{array}{l}\text { Individual excess lifetime cancer risk within or below the acceptable EPA } \\
\text { risk range. }\end{array}$ \\
\hline
\end{tabular}

EPA - U.S. Environmental Protection Agency

Note: These effects could vary from person to person depending on the amount of water a person drinks, his/her body weight and dietary habits, and individual sensitivities such as preexisting kidney or heart diseases. 
For both sites, the concentrations from the other exposure pathways (skin contact with ground water, surface water, and sediment, and fish ingestion) are not expected to cause adverse health effects if they are the only source of exposure. Furthermore, if the additional exposure concentrations are added to the drinking water pathway, the exposure concentrations will not substantially increase the potential for adverse health effects to occur.

\section{ECOLOGICAL ASSESSMENT}

\section{Methods}

The ecological risk assessment presented in this document is a screening level study that relies almost completely on existing site data. This assessment identifies habitats, aquatic life, terrestrial wildlife, and vegetation resources that do not appear to be affected by contamination from the sites, resources that may be affected by contamination, and areas where more information is needed.

The field of ecological risk assessment has many uncertainties, such as a lack of information on how some contaminants affect plants, terrestrial animals, and aquatic life, and a poor understanding of the impacts of two or more contaminants working together. Furthermore, due to limited surface and sediment sampling at the Rifle sites, little or no information is available on possible adverse effects, if any, to the plants and animals at the Rifle sites.

Contaminants that could cause adverse ecological effects are also called contaminants of potential concern. Concentrations of the contaminants detected in surface water, sediment, and ground water are compared to guidelines from regulatory agencies and literature values to determine their possible effects on aquatic life, terrestrial wildlife, and vegetation. Surface water from the Colorado River, Old Rifle pond, and the New Rifle Roaring Fork gravel pit pond was evaluated, as well as sediment from the Colorado River, Old Rifle pond, the south swale, and Pioneer Ditch. Surface water was not collected from the south swale and the Pioneer Ditch because they rarely contain water.

The ecological assessment evaluates the potential for plants to take up contaminated ground water through their roots. It also considers the potential impact of contaminated ground water entering the New Rifle ditch wetlands.

Surface cleanup at the Old and New Rifle sites resulted in the elimination of wetlands. As a replacement, mitigation wetlands are planned. This assessment presents an analysis of the surface water (which will be fed by the contaminated alluvial ground water) and sediment in the proposed mitigation wetlands area.

\section{Results}

The Colorado River and the Old Rifle pond are not measurably affected by ground water contamination. On the other hand, coritaminants have been detected at levels above background in the Roaring Fork gravel pit pond. Nonetheless, contaminants of potential 
concern detected in the pit pond do not exceed the values for the protection of aquatic life or wildlife.

Contaminants detected in sediment from the Colorado River, the south swale, and the Pioneer Ditch indicate concentrations similar to background concentrations. However, sediment quality in the Old Rifle pond has been affected, and aquatic organisms (including fish) could be adversely impacted.

Plants rooted in the contaminated ground water at the Old Rifle site are unlikely to be adversely affected.

Although livestock currently cannot access the Roaring Fork gravel pit pond, existing nitrate concentrations prohibit its use as a water source for livestock.

\section{Planned mitigation wetlands}

Construction of the mitigation wetlands could pose a hazard to ecological receptors. Six contaminants of potential concern in this aquifer (arsenic, cadmium, chloride, iron, manganese, and selenium) exceed federal or state water quality standards for the protection of aquatic life. Also exceeded are two guidelines for terrestrial wildlife (arsenic and vanadium) and seven guidelines for terrestrial plants (arsenic, cadmium, iron, manganese, molybdenum, vanadium, and zinc).

\section{CONCLUSIONS}

For current land use at the Rifle sites, no human health risks are associated with the use of contaminated ground water. This will continue if water use and land use do not change. Once specific land uses for the sites are determined, they should be evaluated to identify potential health and environmental risks from the contaminated ground water or surface water. Given the probability of future residential or industrial development of properties in the Rifle sites area, evaluation of future ground water use has determined the possibility of certain human health problems. Therefore, it is recommended that no one drink the ground water in the contaminated areas. However, it is unlikely that people will drink this ground water because the natural quality of the water in the Rifle area has historically been considered poor and undrinkable, and good water is available from the city of Rifle water supply system. Additionally, the uranium mill tailings (the source of the contamination) are being removed, and contaminated ground water at these sites will tend to disperse and dilute (move away from the site and decrease in concentration), thereby reducing exposure concentrations over time. Furthermore, data from the most contaminated wells on the sites were used in this evaluation. For these reasons, this risk assessment is a conservative estimate of risk to human health at the Rifle sites.

Based on the screening assessment of the ecological environment, some adverse ecological effects to plants and to aquatic and terrestrial wildlife could occur, primarily at the planned mitigation wetlands near New Rifle. If the planned mitigation wetlands are constructed, a postconstruction monitoring program should be implemented to determine whether contaminants are entering the wetlands as predicted and if they pose a potential ecological risk. 
Because of limited data and other limiting factors associated with ecological assessments, more information must be collected to better characterize the ecological environment. This should include additional surface water and sediment data and analyses of fish tissue.

These additional data also will be used to verify the results of the human health screening evaluation of these exposure pathways. Because the plant ingestion pathway for the evaluation of human health was not evaluated due to the lack of scientific information on this exposure route, research data on this pathway should be evaluated when they become available.

The environmental evaluation of the UMTRA Project Rifle sites is ongoing and will include further characterization of ground water quality and movement. This risk assessment and future investigations will be used to determine how to clean up the contaminated ground water. 
TABLE OF CONTENTS

\section{Section}

Page

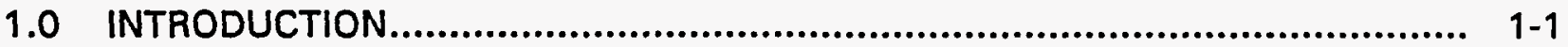

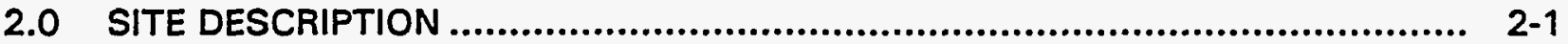

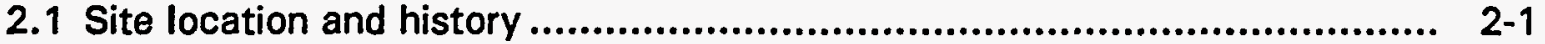

2.1.1 Old Rifle site ...................................................................... $2-1$

2.1.2 New Rifle site ................................................................ 2-5

2.1.3 Previous risk assessment.................................................... 2-5

2.2 Climate..................................................................................... 2-7

2.3 Physiographic setting ..................................................................... 2-8

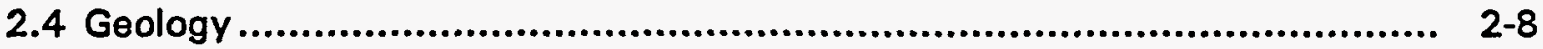

2.4.1 Regional geologic setting .................................................... 2-8

2.4.2 Old and New Rifle site geology .............................................. 2-12

2.5 Hydrogeology ............................................................................ 2-20

2.5.1 Regional hydrogeology .................................................. 2-20

2.5.2 Old and New Rifle site hydrogeology....................................... 2-20

2.6 Surface water hydrology............................................................ 2-26

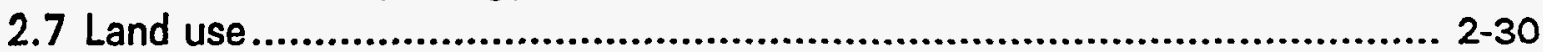

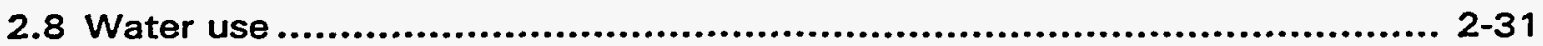

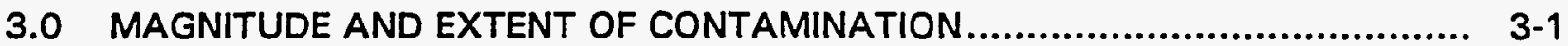

3.1 Background water quality summary .............................................. $3-1$

3.1.1 Alluvial background water ............................................... 3-11

3.1.2 Wasatch background water ................................................ 3-13

3.1.3 Comparison with regional background water............................... 3-14

3.2 Magnitude of site-related contamination ......................................... 3-15

3.3 Surface water and sediment ........................................................ 3-21

3.4 Contaminants of potential concern.................................................. 3-24

3.4.1 Statistical analyses of ground water quality............................ 3-24

3.4.2 Toxicity screening for contaminants of potential concern .............. 3-29

3.5 Contaminant fate and transport ..................................................... 3-31

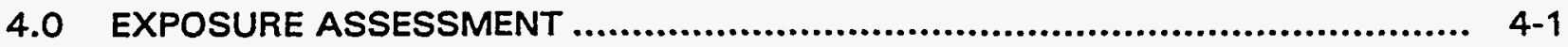

4.1 Potentially exposed population ..................................................... 4-1

4.2 Exposure pathways........................................................................ 4-3

4.2.1 Drinking water ingestion..................................................... 4-3

4.2.2 Dermal contact.................................................................. 4-8

4.2.3 Ingestion of ground water-irrigated produce ............................... 4-8

4.2.4 Ingestion of milk or meat from ground water-fed livestock ............ 4-11

4.2.5 Fish ingestion................................................................... 4-11

4.2.6 Summary ....................................................................... 4-13

4.3 Exposure concentrations............................................................... 4-13

4.4 Estimation of intake through drinking water ........................................ 4-16

4.5 Exposure assessment uncertainties ................................................ 4-19 


\section{TABLE OF CONTENTS (Continued)}

\section{Section}

Page

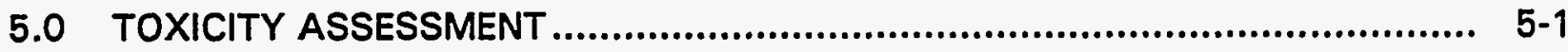

5.1 Contaminant toxicity values .................................................... $5-1$

5.2 Contaminant toxicity summaries.................................................. $5-3$

5.2.1 Ammonia...................................................................... $5-3$

5.2 .2 Antimony............................................................... $5-8$

5.2 .3 Arsenic...................................................................... 5-11

5.2.4 Cadmium ..................................................................... 5-15

5.2.5 Chloride........................................................................ 5-19

5.2.6 Fluoride ...................................................................... 5-20

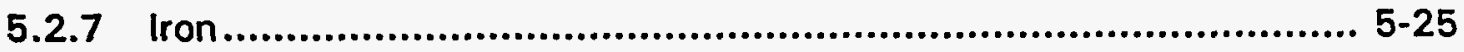

5.2 .8 Lead.......................................................................... 5-28

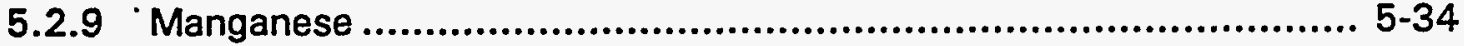

5.2.10 Molybdenum ............................................................... 5-38

5.2 .11 Nitrate........................................................................ 5-40

5.2 .12 Selenium ........................................................................ 5-43

5.2 .13 Sodium........................................................................ 5-46

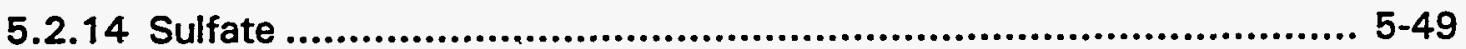

5.2 .15 Uranium .................................................................... 5-51

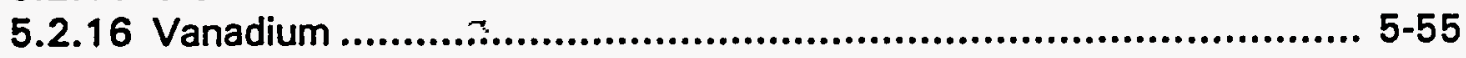

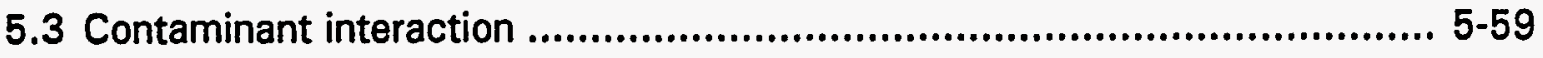

6.0 HUMAN HEALTH RISK EVALUATION.............................................. $6-1$

6.1 Potential future noncarcinogenic risks ............................................. 6.1

6.2 Potential future carcinogenic risks ............................................... 6-25

6.3 Potential risks for the Wasatch Formation....................................... 6-28

6.4 Limitations of the human health risk assessment................................. $6-28$

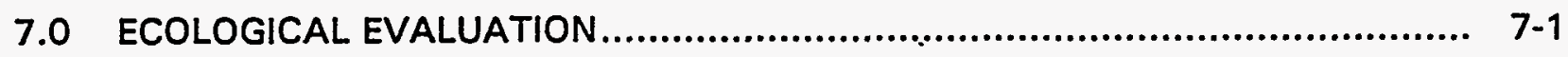

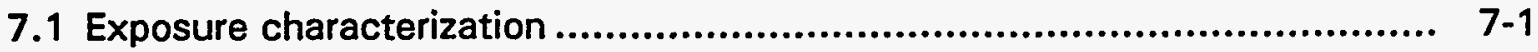

7.1 .1 Ground water ............................................................. $7-2$

7.1.2 Surface water and sediment ............................................. 7-4

7.2 Ecological receptors ............................................................... $7-4$

7.2.1 Terrestrial flora and fauna................................................ 7-4

7.2.2 Aquatic organisms.......................................................... 7-6

7.2.3 Threatened and endangered species ...................................... 7-6

7.3 Ecological contaminants of potential concern..................................... $7-9$

7.3.1 Ground water ................................................................. 7-9

7.3.2 Surface water and sediment ............................................. $7-9$

7.4 Potential impacts $: 0$ wildlife and plants ............................................ 7-13

7.4.1 Ground water ................................................................ 7-15

7.4.2 Surface water and sediment .......................................... 7-21

7.5 Limitations of the ecological risk assessment .................................. $7-25$

7.6 Summary ............................................................................ $7-25$ 


\section{TABLE OF CONTENTS (Concluded)}

Section

Page

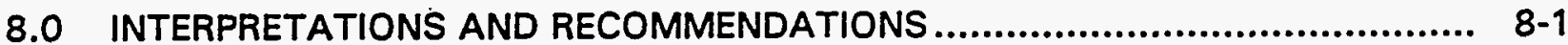

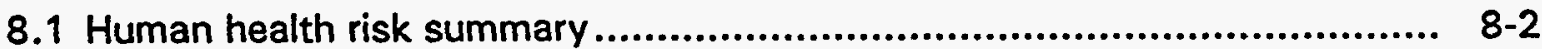

8.2 Ecological risk summary ......................................................... $8-3$

8.3 Ground water standards ............................................................ $8-5$

8.4 Risk mitigation measures ............................................................. $8-5$

8.5 Recommendations ............................................................... $8-7$

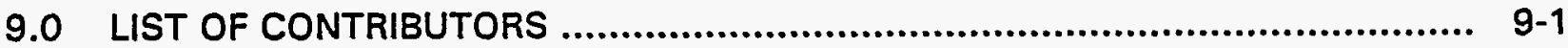

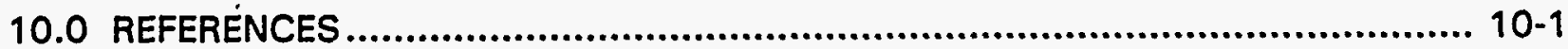




\section{LIST OF FIGURES}

Figure

2.1 Locations of the Rifle, Colorado, processing sites and the Estes Gulch

disposal site ............................................................................... 2-2

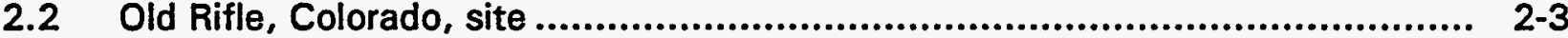

2.3 New Rifle, Colorado, site ............................................................... 2-4

2.4 Regional hydrologic drainage north of Old and New Rifle, Colorado, processing sites .................................................................................. 2-9

2.5 Geologic cross section, Rifle, Colorado, sites and region north ...................... 2-11

2.6 Alluvial aquifer and Wasatch Formation monitor well and private well location map, Old Rifle, Colorado, site .................................................... 2-13

2.7 Alluvial aquifer and Wasatch Formation monitor well and private well location map, New Rifle, Colorado, site ................................................ 2-14

2.8 Generalized geologic cross section A-A' (southwest to northeast), Old Rifle, Colorado, site ................................................................................... 2-19

2.9 Generalized geologic cross section A-A' (southwest to northeast), New Rifle, Colorado, site .............................................................................. 2-21

2.10a Water table contour map of the alluvial aquifer, Old Rifle, Colorado, processing site vicinity

2.10b Potentiometric surface map of the Wasatch Formation, Old Rifle, Colorado, processing site vicinity

2.11a Water table contour map of the alluvial aquifer, New Rifle, Colorado, processing site vicinity.................................................................. 2-24

2.11b Potentiometric surface map of the Wasatch Formation, New Rifle, Colorado, processing site vicinity..................................................................... 2-24

2.12 Surface water/sediment sampling locations, Old and New Rifle, Colorado, sites

3.1 Trilinear diagram, major element composition of alluvial and Wasatch Formation background ground water, Rifle, Colorado, site ............................ 3-12

3.2 Uranium isopleth map for the alluvial aquifer, Old Rifle, Colorado, site, March 1992

3.3 Uranium isopleth map for the alluvial aquifer, New Rifle, Colorado, site, March 1994

3.4 Uranium isopleth map for the Wasatch Formation at New Rifle, Colorado, site, March 1994

4.1 Rifle, Colorado, site conceptual model .................................................... 4-4

4.2 Screening exposure scenarios for potential human receptors, Rifle, Colorado, sites

5.1 Ammonia toxicity ranges

5.2 Antimony toxicity ranges

Chloride toxicity ranges 


\section{LIST OF FIGURES (Continued)}

Figure

Page

5.6 Fluoride toxicity ranges................................................................ 5-26

5.7 Iron toxicity ranges.................................................................... 5-29

5.8 Lead toxicity ranges .................................................................... 5-35

5.9 Manganese toxicity ranges................................................................. 5-39

5.10 Molybdenum toxicity ranges ............................................................ 5-41

5.11 Nitrate toxicity ranges for infants...................................................... 5-44

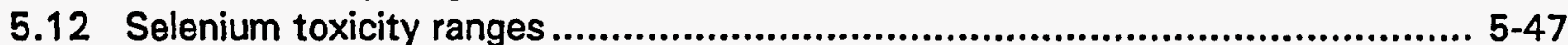

5.13 Sodium toxicity ranges ................................................................... 5-50

5.14 Sulfate toxicity ranges ............................................................... 5-52

5.15 Half-lives and emissions from decay chain of uranium-238 ........................ 5-54

5.16 Uranium toxicity ranges ............................................................... 5-56

5.17 Vanadium toxicity ranges ............................................................... 5-60

6.1 Health effects of potential molybdenum exposure ranges for children,

Old Rifle, Colorado, site

6.2 Health effects of potential sulfate exposure ranges for infants, Old Rifle, Colorado, site

6.3 Health effects of potential manganese exposure ranges for children, Old Rifle, Colorado, site ................................................................................. 6 6

6.4 Health effects of potential iron exposure ranges for children, Old Rifle, Colorado, site................................................................................................ 6.6 $6-6$

6.5 Health effects of potential fluoride exposure ranges for children, Old Rifle, Colorado, site

6.6 Health effects of potential arsenic exposure ranges for children, New Rifle, Colorado, site

6.7 Health effects of potential manganese exposure ranges for children, New Rifle, Colorado, site

6.8 Health effects of potential nitrate exposure ranges for infants, New Rifle, Colorado, site

6.9 Health effects of potential selenium exposure ranges for children, New Rifle, Colorado, site

6.10 Health effects of potential molybdenum exposure ranges for children, New Rifle, Colorado, site

6.11 Health effects of potential sulfate exposure ranges for infants, New Rifle, Colorado, site

6.12 Health effects of potential sodium exposure ranges for children, New Rifle, Colorado, site

6.13 Health effects of potential chloride exposure ranges for children, New Rifle, Colorado, site

6.14 Health effects of potential fluoride exposure ranges for children, New Rifle, Cclorado, site

6.15 Health eiffects of potential iron exposure ranges for children, New Rifle, Colorado, site 
LIST OF FIGURES (Concluded)

Figure

6.16 Health effects of potential vanadium exposure ranges for children, New Rifle, Colorado, site ................................................................................... 6-20

6.17 Health effects of potential ammonium exposure ranges for children, New Rifle, Colorado, site ................................................................................. 6-21

7.1 Location of ditch and planned mitigation wetlands, New Rifle, Colorado, site ... 7-3 


\section{LIST OF TABLES}

Table

Page

2.1 Monitor and private well/spring information for Old and New Rifle, Colorado, sites

2.2 Surface water/sediment sample location information for Old and New Rifle, Colorado, sites.

2.3 Private wells sampled in the vicinity of the Old and New Rifle, Colorado, sites

3.1 Summary of ground water quality in the alluvial aquifer, Rifle, Colorado, processing sites, August 1990 to August 1994, filtered samples ..

3.2 Summary of water quality in the Wasatch Formation, Rifle, Colorado, processing sites, August 1990 to August 1994, filtered samples.

3.3 Constituents detected in surface water bodies in the vicinity of the Rifle, Colorado, sites.

3.4 Contaminants of potential concern for human health evaluation for the alluvial aquifer at the Old Rifle, Colorado, site

3.5 Contaminants of potential concern for human health evaluation for the alluvial aquifer at the New Rifle, Colorado, site

3.6 Contaminants of potential concern for human health evaluation in the weathered Wasatch Formation aquifer at the New Rifle, Colorado, site

3.7 Stable species of constituents of concern in the ground water system, Rifle, Colorado, site, at observed Eh and $\mathrm{pH}$ conditions...

4.1 Exposure dose calculations for alluvial ground water ingestion and dermal contact by an adult in a future hypothetical scenario, Rifle, Colorado, sites .......

4.2 Exposure dose calculations for incidental surface water ingestion and dermal contact for children swimming in Old Rifle pond, Rifle, Colorado, sites

4.3 Exposure dose calculations for incidental sediment ingestion and dermal contact for children swimming in Old Rifle pond, Rifle, Colorado, sites

4.4 Exposure dose calculations for adult ingestion of fish from Old Rifle pond, Rifle, Colorado, site

4.5 Probability distribution specifications for contaminant concentrations for the alluvium at the Old and New Rifle sites and Wasatch Formation at the New Rifle site 4-14

5.1 Toxicity values: potential noncarcinogenic effects

5.2 Toxicity values: carcinogenic effects.

6.1 Risk evaluation of antimony and lead detected in the alluvium at the New Rifle, Colorado, site

6.2 Individual excess lifetime cancer risk calculations for ground water ingestion by a hypothetical future adult resident, Rifle, Colorado, sites 


\section{LIST OF TABLES (Concluded)}

Table

7.1 Bird species that could nest at the mitigation wetlands, Rifle, Colorado, sites.... 7-7

7.2 Sediment data from water-bodies in the vicinity of the Rifle, Colorado, sites, March 1994

7.3 Constituents of potential concern in the alluvial aquifer at the mitigation wetland and the New Rifle ditch wetland.

7.4 Comparison of contaminants of potential concern in surface water from ponds in the vicinity of the sites with available water quality values, Rifle, Colorado, sites.

8.1 Maximum concentration limits of constituents........................................ 8-6 


\section{LIST OF ACRONYMS}

Acronym

AEC

ALAD

ANOVA

$B C F$

${ }^{\circ} \mathrm{C}$

CDPHE

DHHS

DOE

EIS

EPA

ESADD

${ }^{\circ} \mathrm{F}$

FWOC

FWS

HEAST

HI

HO

IRIS

LOAEL

$\mathrm{MCL}$

NCP

NEPA

NOAA

NOAEL

PEIS

RDA

RfD

RRM

SOC

$T \& E$

TDS

UCL

UMTRA

UMTRCA

\section{Definition}

Atomic Energy Commission

$\delta$-aminolevulinic acid dehydratase

analysis of variance

bioconcentration factors

degrees celsius

Colorado Department of Public Health and Environment

Department of Health and Human Services

U.S. Department of Energy

environmental impact statement

U.S. Environmental Protection Agency

estimated safe and adequate daily dietary intake

degrees Fahrenheit

Federal Water Quality Criterion

U.S. Fish and Wildlife Service

Health Effects Assessment Summary Tables

hazard index

hazard quotient

Integrated Risk Information System

lowest-observed-adverse-effect level

maximum concentration limit

National Contingency Plan

National Environmental Policy Act

National Oceanic and Atmospheric Administration

no-observed-adverse-effect level

programmatic environmental impact statement

recommended dietary allowance

reference dose

residual radioactive materials

sediment quality criteria

threatened and endangered

total dissolved solids

upper confidence limit

Uranium Mill Tailings Remedial Action

Uranium Mill Tailings Radiation Control Act 


\subsection{INTRODUCTION}

The purpose of this baseline risk assessment is to determine if ground water contamination at the two abandoned uranium mill processing sites near Rifle, Colorado, could adversely affect public health or the environment. The Old and New Rifle sites are two of the 24 abandoned uranium processing sites that are undergoing remediation in accordance with the requirements of the Uranium Mill Tailings Radiation Control Act (UMTRCA) of 1978 (42 USC $\$ 7901$ et seq.) under the oversight of the U.S. Department of Energy (DOE) Uranium Mill Tailings Remedial Action (UMTRA) Project. The 1988 amendments to the UMTRCA authorize the DOE to conduct ground water restoration activities. Under the UMTRA Ground Water Project, site-related ground water contamination is being evaluated and an appropriate ground water compliance strategy will be selected. Results of this risk assessment will be included in the development of a ground water compliance strategy for the Rifle sites.

Under the UMTRA Surface Project at the Old and New Rifle sites, the source of ground water contamination, residual radioactive material (RRM), is being stabilized in an off-site disposal cell at Estes Gulch. The disposal cell is engineered to prevent radon and other radiation emissions, and to prevent ground water contamination. Surface remedial action at the Old and New Rifle sites began in 1992 and is scheduled for completion in 1995. The evaluation of risks from surface soil contamination and the off-site disposal cell are not within the scope of this risk assessment. Completion of surface remedial action will prevent further ground water contamination at the processing sites.

The Programmatic Environmental Impact Statement (PEIS) for the Uranium Mill Tailings Remedial Action Ground Water Project (DOE, 1994a) presents a proposed framework for selecting a ground water compliance strategy to meet the U.S. Environmental Protection Agency (EPA) ground water standards for the UMTRA Project (40 CFR 192). This baseline risk assessment evaluates potential current and future human health and environmental risks from ground water contamination at the Old and New Rifle processing sites, and provides information to help determine the ground water compliance strategy. Remaining data gaps in ground water characterization will be addressed in the Old and New Rifle site observational work plan. Based on the PEIS, the site observational work plan, and this risk assessment, site-specific National Environmental Policy Act (NEPA) documentation will be prepared to identify impacts from the proposed ground water compliance strategy for the Old and New Rifle sites.

This risk assessment is a baseline assessment in that it describes preremediation ground water conditions at the site, with ground water quality only partially characterized. This document evaluates potential risks that may need attention before the site is fully characterized, and with available ground water data, examines risk to human health and the ecology from the most contaminated wells at each processing site.

This risk assessment follows the human health risk assessment methodology for the UMTRA Ground Water Project (DOE, 1994b). This methodology is designed to evaluate human health risks associated with ground water contamination at inactive uranium processing sites. It allows the development of probabilistic distributions for exposure 
variables when data are sufficient and the simulation of exposure dose distributions, using Monte Carlo techniques rather than a single exposure dose calculation. Risk interpretation is based on a comparison between the predicted exposure dose distribution and the observed toxicity ranges of contaminants of potential concern. Graphic presentations (figures) are essential to interpreting exposure dose distributions because they are designed to help the public and decision-makers understand the adverse health effects of the contaminants of potential concern.

The methodology used for the ecological portion of this risk assessment is the EPA's Risk Assessment Guidance for Superfund (EPA, 1989a). This methodology uses a qualitative approach to evaluate ecological risks.

This ecological risk assessment evaluates the ecological environment of the two Rifle sites as one unit. Ecological risk assessment at the Rifle sites identifies potentially exposed habitats and qualitatively evaluates analytical data to describe how contamination could affect these habitats. Thus, this qualitative approach provides a screening level assessment of the risks associated with potential exposure to contaminated media at the site. 


\subsection{SITE DESCRIPTION}

\subsection{SITE LOCATION AND HISTORY}

The Rifle UMTRA Project sites are two separate former processing sites in the vicinity of the city of Rifle in Garfield County, in western Colorado (Figure 2.1). Known as the Old Rifle site, the eastern site is approximately $0.3 \mathrm{mile}$ (mi) 10.5 kilometer [km]) east of the center of Rifle. Known as the New Rifle site, the western site is approximately $2 \mathrm{mi}(3 \mathrm{~km})$ southwest of the center of Rifle. The Colorado River is south of both sites. The Old Rifle site covers approximately 22 acres (ac) 19.0 hectares [ha]), between U.S. Highway 6 to the north and the Denver and Rio Grande Western Railroad embankment and the Colorado River to the south (Figure 2.2). The New Rifle site covers approximately 142 ac (58 ha) between U.S. Highway 6 to the north and Interstate 70 and the Colorado River to the south (Figure 2.3). Both the Old Rifle and New Rifle sites were constructed, owned, and operated by the Union Carbide Corporation (Union Carbide) and its predecessor, the United States Vanadium Corporation. The designated Rifle processing sites are in sections 15 through 18, Township 6 South, Range 12 East, Sixth Principal Meridian. The state of Colorado acquired both sites in 1988, as specified by the UMTRCA.

\subsubsection{Old Rifle site}

Union Carbide owned and operated the Old Rifle uranium mill site from 1924 to 1932 and from 1942 to 1958 . From 1932 to 1942 , the mill was idle for economic reasons. The mill produced vanadium during both operating periods and uranium during the later period. Ore was shipped to the mill by truck and railroad from eastern Utah and from the Uravan Mineral Belt and Meeker and Rifle Creek mines in Colorado. Atomic Energy Commission (AEC) records from 1947 to 1958 show that 761,000 tons $(690,000$ metric tons) of ore were processed at the site and over 2000 tons (1800 metric tons) of uranium concentrate were sold to the AEC. After 1958, most of the tailings at the Old Rifle site were reprocessed and deposited at the New Rifle site (DOE, 1990). The chemicals used in the process are described in Section 3.2.

Approximately 13 ac (5.3 ha) of tailings remained at the Old Rifle processing site prior to surface remedial action. No structures remained at the mill site. The relatively flat tailings pile was at the base of the cliff below Highway 6 . The tailings pile was partially stabilized by Union Carbide in 1967, in accordance with state of Colorado regulations. The edge of the pile was moved away from the railroad tracks and the entire pile was covered with 6 inches (15 centimeters [cm]) of soil, fertilized, and seeded with native grasses. Water from the Colorado River was used for irrigation. Surface water drainage originating from an upgradient seep across Highway 6 flows through the site. A lined pond collected this seep water as it passed the pile before releasing it to the Colorado River. This pond was removed during surface remedial action. 

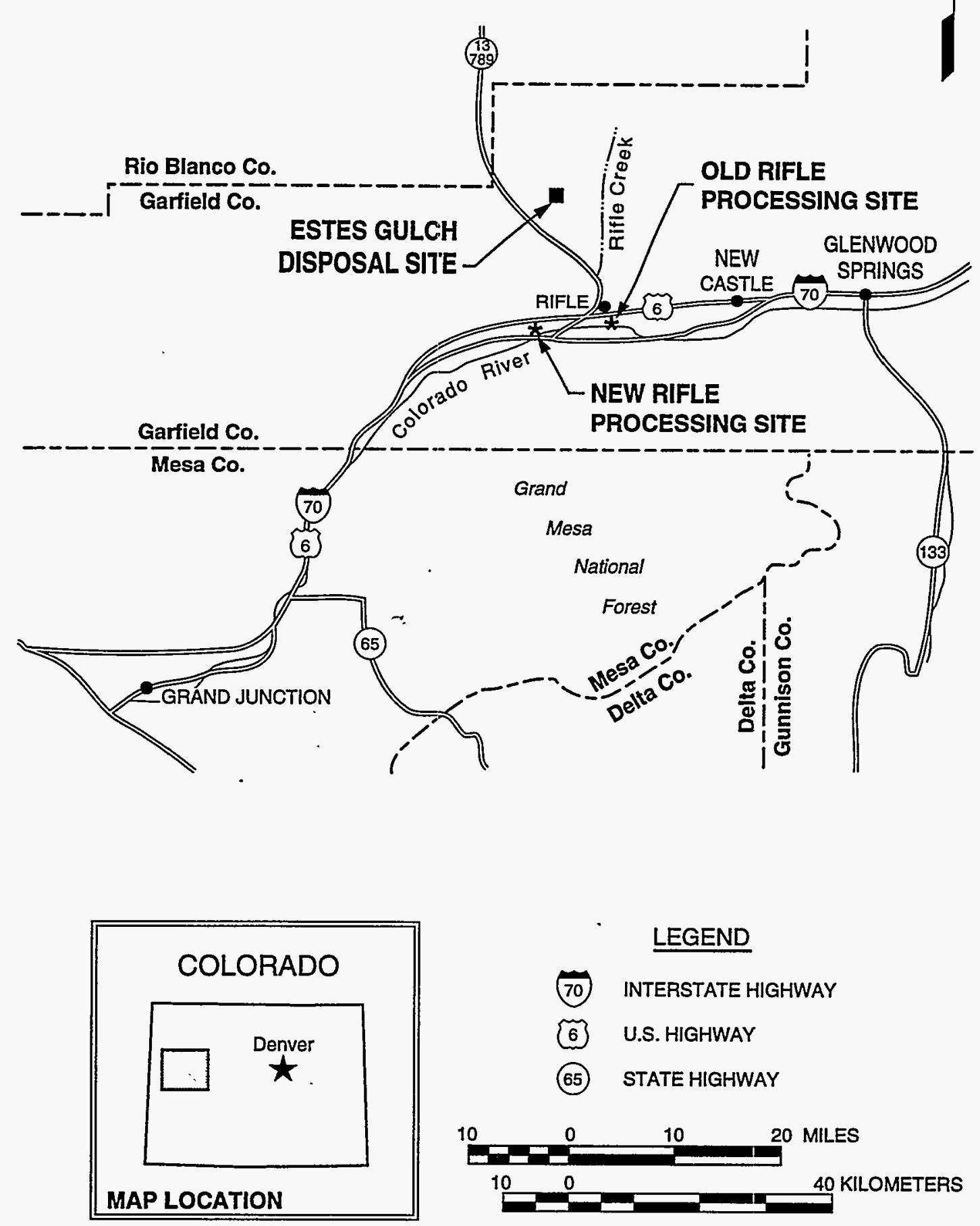

\section{LEGEND}

(70) INTERSTATE HIGHWAY

(6) U.S. HIGHWAY

(65) STATE HIGHWAY

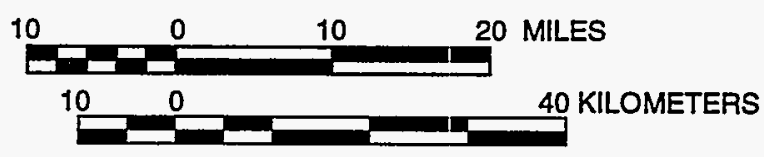

FIGURE 2.1

LOCATIONS OF THE RIFLE, COLORADO, PROCESSING SITES AND THE ESTES GULCH DISPOSAL SITE 


\subsubsection{New Rifle site}

The New Rifle mill replaced the Old Rifle mill in 1958, and was owned and operated by Union Carbide. The mill was constructed as part of a multisite complex that included the upgraders at Slick Rock, Colorado, and Green River, Utah. Ore and upgrader products from those sites were shipped to the New Rifle mill by truck and railroad. From 1958 to 1973, the mill produced uranium and vanadium; AEC records show that $2,259,000$ cubic yards $\left(y d^{3}\right)(1,727,000$ cubic meters $\left.\left[\mathrm{m}^{3}\right]\right)$ of Old Rifle tailings and ore were processed and upgrade products were refined. Over 5000 tons (4500 metric tons) of uranium concentrate were sold to the $\mathrm{AEC}$, and additional uranium and vanadium products were sold commercially. From 1973 to 1984, part of the mill was used to produce vanadium; this operation involved processing vanadium solutions and did not produce tailings. The chemicals used to process uranium and vanadium are described in Section 3.2.

The west central portion of the New Rifle mill site contained 33 ac (13 ha) of tailings, and a mill area north and east of the pile. Former ponds that had held processing wastes (including vanadium and gypsum) were east of the tailings piles. All buildings and structures were demolished during Phase I of surface remedial action. Prior to that, the site contained the mill facilities, water retention ponds, and two ore storage areas. The tailings were partially stabilized with the application of mulch and fertilizer and an irrigation system was installed. Much of the pile did not revegetate, and wind and water eroded the tailings pile.

Surface remedial action of the Rifle sites began in the spring of 1992 and is scheduled for completion in 1995. Tailings from both the New and Old Rifle processing sites are being relocated to the Estes Gulch disposal site approximately $9 \mathrm{mi}(15 \mathrm{~km})$ north of the New Rifle site.

\subsubsection{Previous risk assessment}

The 1992 Rifle baseline risk assessment was conducted to estimate the following conditions and/or activities:

- Then-current risks from the use of potentially contaminated domestic wells.

- The future use of ground water at both Rifle sites.

- The then-current use of the fishing pond east of Rifle.

- The potential use of the gravel pit pond west of Rifle.

- Incidental contact with water in the ditch west of New Rifle.

A screening level environmental evaluation also was conducted in 1992 to determine potential impacts to aquatic biota.

The methodology used for the 1992 risk assessment was the risk assessment guidance for Superfund (EPA, 1989a). The 1992 risk assessment methodology 
differed from the current (1995) risk assessment in that the hazard quotient (HO) approach was used to evaluate noncarcinogenic risks. The $\mathrm{HO}$ is defined as the ratio of a single substance exposure level over a specified period to a reference dose for that substance. When two or more HOs are added together, the resulting number is called a hazard index (HI). When an $\mathrm{HI}$ exceeds 1.0, adverse health effects can occur. For the 1995 risk assessment, exposure dose probability distributions were generated to evaluate noncarcinogenic risks.

Carcinogenic risks were evaluated using the same methodology in both risk assessments (i.e., individual excess cancer risks were calculated).

In addition to the different methodologies used to evaluate noncarcinogenic risk for the two baseline risk assessments, a better understanding of the Rifle sites' hydrogeology has been developed since the 1992 risk assessment. The locations of two of the four wells (RFO-01-0597 and -0598 and RFN-01-0600 and -0601 ) that were evaluated as background wells for the alluvial aquifer were determined to be inappropriate to define background. Wells RFO-01-0597 and -0598 are in locations that justifiably can be used as background because they are upgradient of the Old Rifle site, they are in the same hydrogeologic unit, and they are not impacted by uranium mill processing activities. However, RFO-01-0600 is located across the Colorado River in a different hydrogeologic unit than the Rifle sites, and this well is influenced by the river (causing a dilution effect). Using this well as background could have biased the 1992 risk assessment, making background concentrations appear to be lower than they are. Because well RF0-01-0601 is downgradient of Old Rifle and the water quality in this well has not been established, determining background based on this well is not appropriate. Therefore, two additional wells were constructed upgradient of Old Rifle for the 1995 background evaluations. Additionally, the 1992 risk assessment identified several wells as downgradient from the New Rifle site although these wells are crossgradient from the site.

The 1992 risk evaluation included the following assessments:

- Current evaluation for private wells downgradient of both Rifle sites. All but one household used bottled water for drinking water, and it was assumed that for all other household purposes 0.5 liter $(L)$ per day was consumed. An ingestion rate of $2 \mathrm{~L}$ of contaminated ground water per day was assumed for the one household that did not consume bottled water. For all scenarios, the $\mathrm{HI}$ fell below 1 (where adverse health effects would not be expected). Carcinogenic risks fell within the acceptable range 1E-06 (1 chance in $1,000,000$ ) to $1 \mathrm{E}-04$ ( 1 chance in 10,000).

If all private well users were assumed to ingest $2 \mathrm{~L}$ per day, adverse health effects could be expected (i.e., HOs would exce ed 1 for fluoride, manganese, and uranium). Carcinogenic risks would exceed the acceptable range of $1 \mathrm{E}-06$ to $1 \mathrm{E}-04$, primarily due to uranium. 
- Future evaluation of ground water. Contamination levels (especially nitrate concentrations) were sufficiently high in off-site monitor wells to be of concern. Additionally, antimony, arsenic, cadmium, fluoride, molybdenum, uranium, and vanadium exceeded the HOs at both sites; chromium exceeded the $\mathrm{HQ}$ at New Rifle, and manganese and selenium exceeded the $\mathrm{HO}$ at Old Rifle. Carcinogenic risks exceeded the EPA acceptable risk range of 1E-06 to 1E-04 for uranium and arsenic at both sites.

- Commercial wells. Little potential existed for noncarcinogenic risk associated with the use of contaminated ground water downgradient of both sites. Carcinogenic risks fell within the EPA acceptable risk range, assuming a 30-year exposure period and a consumption of $1 \mathrm{~L}$ per day. All businesses provided bottled water because of the poor taste of the well water.

- Long-term routine consumption of fish from the Old Rifle pond. This could result in carcinogenic risk, primarily from uranium and lead-210, that exceeds the EPA risk level of 1E-04.

- Surface water. No impact to the Colorado River would be likely from site activities. A small potential for impact existed to aquatic or benthic organisms in the ponds and drainage ditch.

The results of the 1992 risk assessment were considered preliminary because data were limited and two of the four background locations were determined inappropriate for background water quality evaluation. Additional characterization was recommended. The current risk assessment provides an updated evaluation based on additional data and site characterization as well as an analysis that uses the risk assessment methodology adopted in 1992 for the UMTRA Ground Water Project (DOE, 1994b).

\subsection{CLIMATE}

The Rifle region has a semiarid climate with low precipitation and low humidity, large temperature variations, and high evaporation. The Colorado River Valley and surrounding steep canyons and plateaus range in elevation from 5400 feet (ft) (1500 meters [m]) in the valley to approximately $10,500 \mathrm{ft}(3200 \mathrm{~m})$ on the plateaus. Elevation, exposure, geographic location, and topographic wind channeling affect the weather differently at different locations.

The interior Colorado River Valley is surrounded by mountains and receives little precipitation. Consequently, agriculture is dependent on irrigation; mountain snow melt and rain provide an adequate supply of water for irrigation. Summer rains occur mainly as scattered light showers from thunderstorms that develop in the mountains. The average summer temperature is 70 degrees Fahrenheit ( $\left.{ }^{\circ} \mathrm{F}\right)$. Winter snows are frequent, but are mostly light and melt quickly. The average winter temperature is $23^{\circ} \mathrm{F}$. The average annual precipitation for Rifle 
was 11 inches $(28 \mathrm{~cm})$ from 1931 through 1980. Snowfall in the Rifle region averages 41 inches $(104 \mathrm{~cm})$ per year.

\subsection{PHYSIOGRAPHIC SETTING}

The Rifle area is on the northeastern edge of the Colorado Plateau Physiographic Province near its boundary with the Southern Rocky Mountain Physiographic Province. Principal physiographic elements that are within the region of hydrologic influence include the Colorado River Valley; the Grand Hogback monocline, which forms the western boundary of the Southern Rocky Mountain Physiographic Province; and the White River Plateau (Figure 2.41. Other features within the region of the Rifle sites are Grass and Taughenbaugh Mesas to the south and the Roan Cliffs to the west.

The region upgradient (north) of the Rifle sites is characterized by mature, stream-eroded upland pediment surfaces, large structural upwarps, and intervening basins. Topographic elevations in the region range from $5400 \mathrm{ft}$ $(1600 \mathrm{~m})$ above sea level along the Colorado River near the former Rifle processing sites to $8000 \mathrm{ft}(2400 \mathrm{~m})$ above sea level along the Grand Hogback monocline to $10,500 \mathrm{ft}(3200 \mathrm{~m})$ above sea level along the White River Plateau. Figure 2.4 illustrates this topographic variability.

\subsection{GEOLOGY}

Regional and local geologic conditions relevant to the risk assessment are described below. Geologic information supports the conclusions regarding regional and on-site ground water and surface water flow.

\subsubsection{Regional geologic setting}

Quaternary deposits near the Rifle sites are represented by sediments consisting of pediment graveis of several ages, glacial drift and outwash, landslide deposits, fluvially deposited alluvium, and colluvium. Four levels of river terraces and associated pediments formed during two glacial advances are present in the Rifle area (Sinnock, 1981). Pediment deposits consist of coarse gravel, cobbles, and boulders in a clayey-silt matrix. Unconsolidated fluvial alluvium is present along the Colorado River channel and along major tributaries such as Rifle Creek. Near Rifle, the alluvium is approximately 16 to $25 \mathrm{ft}(4.8$ to $7.6 \mathrm{~m}$ ) thick (DOE, 1992a).

Although it is not present at the Rifle sites, northwest of Rifle the more resistant Green River Formation overlies strata of the Wasatch Formation, forming the prominent Roan Cliffs. These cliffs are visible from the Rifle sites and the Colorado River (Figure 2.4). The Tertiary Green River Formation consists of cil shales, sandstones, and marlstones.

Figure 2.5 shows a generalized cross section of the region directly north of the city of Rifle. Shallow bedrock in the southern part of the region (generally 


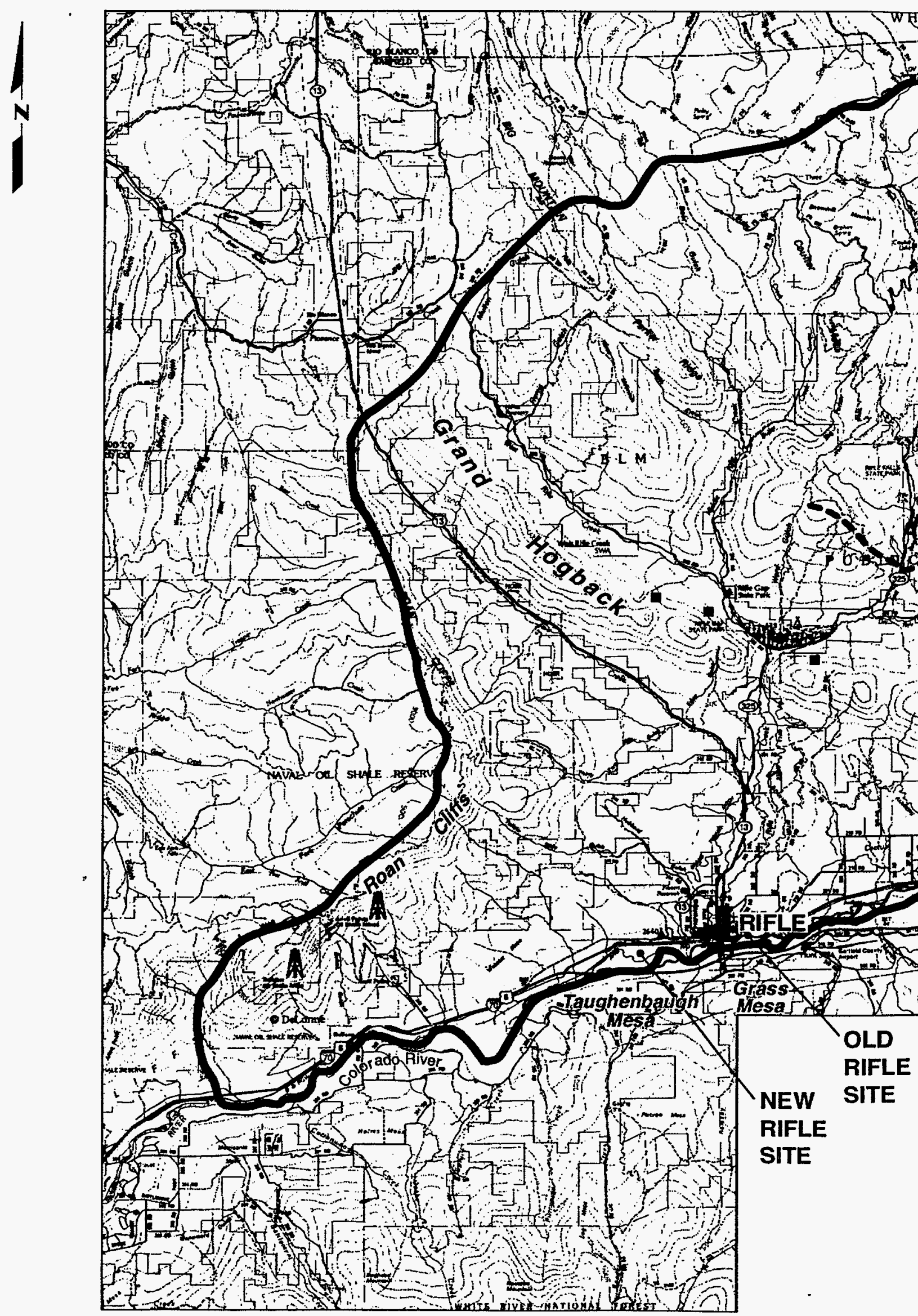




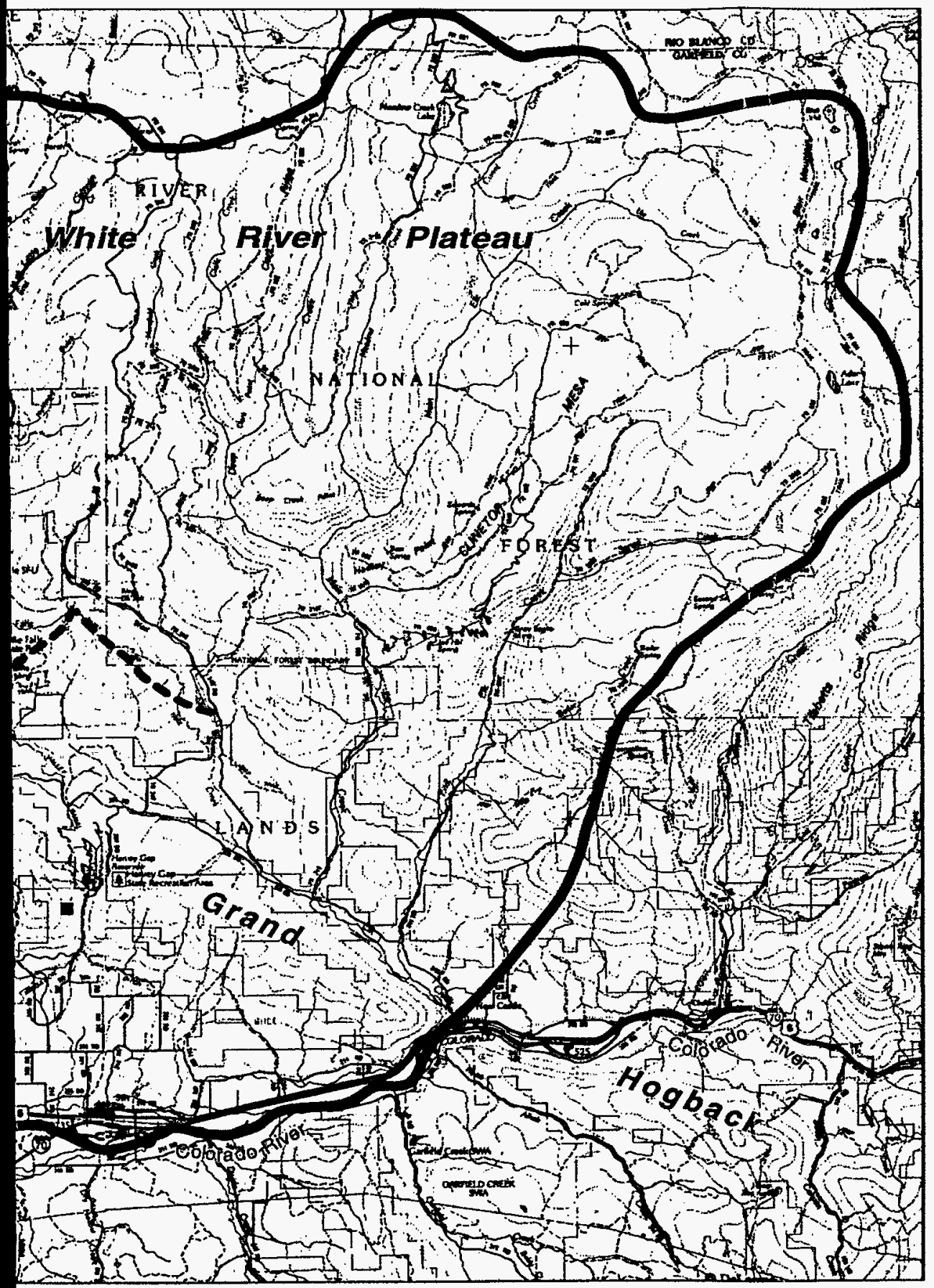

\section{LEGEND}

REgIONAL DRAINAGE BOUNDARY 


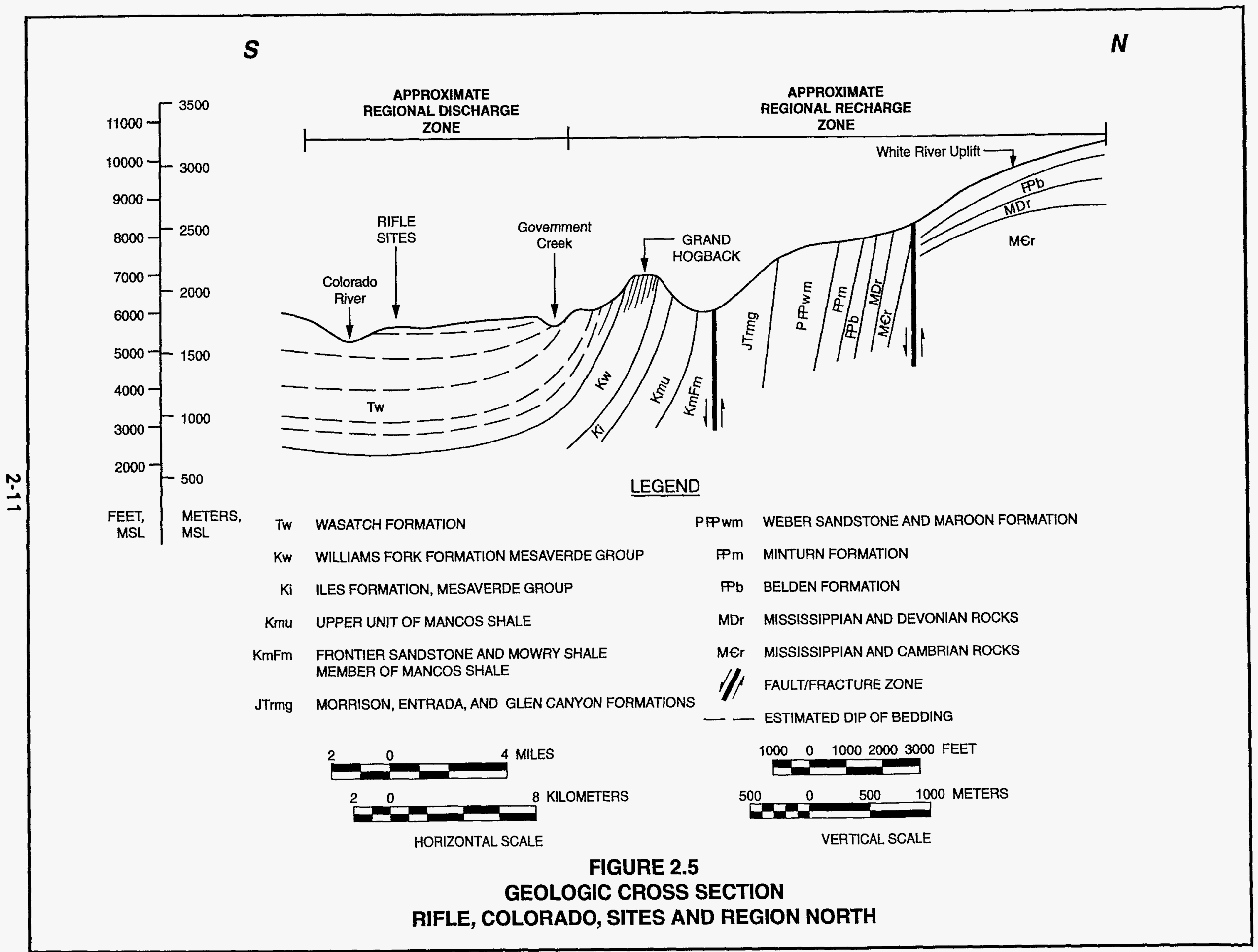


between the Colorado River and the Grand Hogback monocline) consists of variegated claystone, siltstone, and fine-grained sandstone of the Wasatch Formation. Although the Wasatch Formation contains some resistant beds that form cliffs, most of the formation weathers easily and has formed lowland mesas, including the Prefontaine and Graham Mesas directly northwest and northeast of the city of Rifle. The sedimentary beds of the Wasatch Formation generally dip southwest (toward the axis of the Colorado River Basin) in the vicinity of the sites. However, the dip steepens rapidly to a near-vertical orientation along the face of the Grand Hogback monocline. Numerous faults cutting Precambrian to Tertiary bedrock occur along the Grand Hogback monocline and landslide deposits occur on the steeply dipping rock surfaces. Directly north of the Grand Hogback and extending another $6 \mathrm{mi}(10 \mathrm{~km})$ north are a series of near-vertical beds of late Permian, Mesozoic, and Cambrian age, including the vanadium and uranium-bearing Morrison and Entrada Formations (Figure 2.5). Figure 2.4 shows the location of the Entrada Sandstone, which contains developed vanadium and uranium deposits.

Southwest of the town of Rifle and the Colorado River, Battlement Mesa rises to a height of nearly $11,000 \mathrm{ft}(3400 \mathrm{~m})$, with the highest surfaces capped by basaltic lava flows. The northern slope of the mesa consists of multiple levels of pediments and alluvial fans that slope toward the Colorado River.

\subsubsection{Old and New Rifle site geology}

The Old and New Rifle tailings sites rest on Quaternary Colorado River floodplain alluvium, which consists of silt, sand, gravel, and cobbles. The alluvium directly overlies the Wasatch Formation at the Old Rifle site and is approximately $20 \mathrm{ft}$ $(6 \mathrm{~m})$ thick, with depths to ground water ranging from approximately 2 to $22 \mathrm{ft}$ $(0.5$ to $7 \mathrm{~m})$ below land surface. The alluvium at the New Rifle site is 25 to $35 \mathrm{ft}(8$ to $11 \mathrm{~m})$ thick and depths to ground water range from approximately 2 to $57 \mathrm{ft}(0.6$ to $17 \mathrm{~m})$. Figures 2.6 and 2.7 show monitor well locations at each site and private wells near the sites. Table 2.1 lists the formation of completion, screened interval, dates sampled, and flow relation for DOE and private wells in the vicinity of the processing sites. Wells recently installed for this risk assessment include Old Rifle background wells RFO-01-0605 and -0606 and New Rifle downgradient well RFN-01-0620.

Topographic contours in Figure 2.6 show that the Old Rifle site sits along a lowlying, erosional meander of the Colorado River. The more resistant cliff-forming beds of the Wasatch Formation outcrop abruptly, directly west and north (downgradient) of the site. These resistant cliffs control the northern extent of the alluvium at Old Rifle. The alluvium narrows considerably west of the Old Rifle site because of the more erosional-resistant Wasatch beds.

$A$ crose section (profile A-A') of Old Rifle (Figures 2.6 and 2.8) shows that most of the Old Rifle site was overlain with a layer of approximately $15 \mathrm{ft}(5 \mathrm{~m})$ of tailings materials consisting of silty sands and slimes. These materials, which are being removed during surface remedial action, were placed directly over 


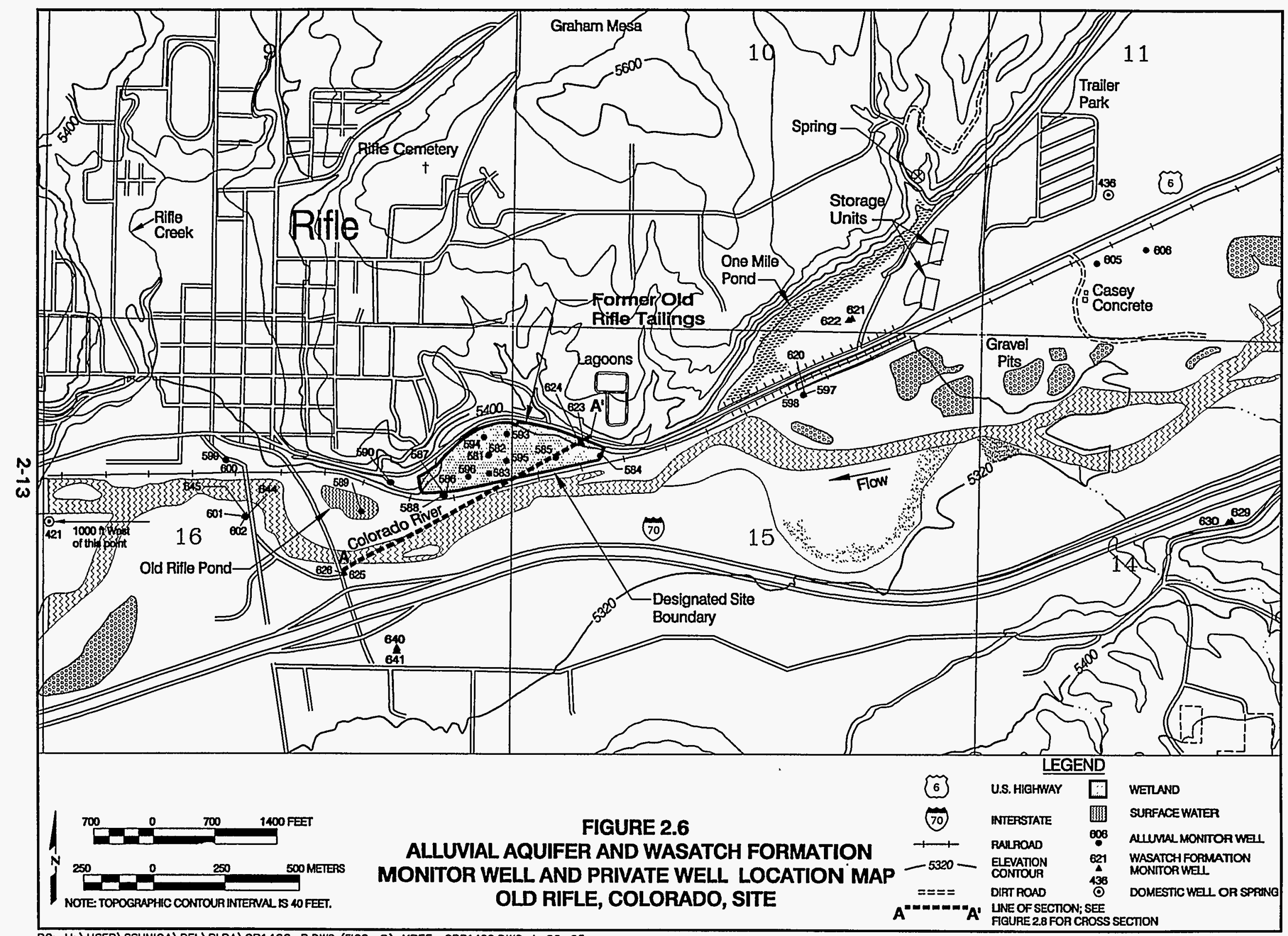

PC: H: \USER \SSUNIGA \RFL \BLRA \OR1400-B.DWG (FIG2-6) XREF: ORB1400.DWG 4-20-95 


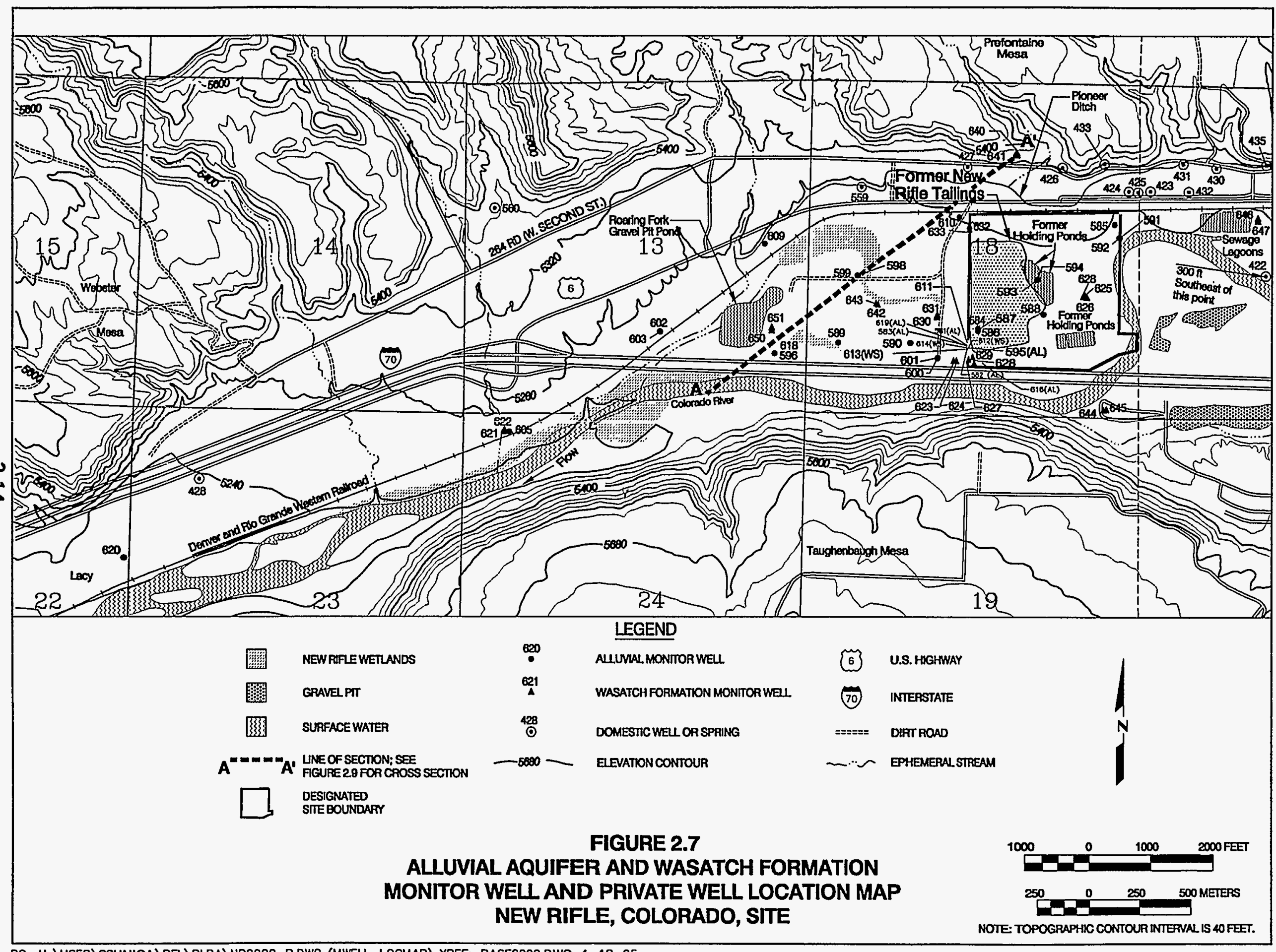

PC: H: \USER\SSUNIGA \RFL \BLRA\NR2000-B.DWG (MWELL-LOCMAP) XREF: BASE2000.DWG 4-18-95 
Table 2.1 Monitor and private well/spring information for Old and New Rifle, Colorado, sites

\begin{tabular}{|c|c|c|c|c|c|}
\hline Location ID & $\begin{array}{c}\text { Unit } \\
\text { screened }\end{array}$ & $\begin{array}{c}\text { Screen } \\
\text { interval }^{\circ} \\
\text { (completion } \\
\text { depth) }\end{array}$ & $\begin{array}{c}\text { Date sampled } \\
\text { (year) }\end{array}$ & $\begin{array}{c}\text { Flow } \\
\text { relation }\end{array}$ & Decommissioned \\
\hline \multicolumn{6}{|l|}{ OLD RIFLE } \\
\hline RFO-01-540 & Qal & $16-45$ & $81,87,91$ & Crossgradient & $x$ \\
\hline RFO-01-541 & Qal & $39-159$ & $81,82,87,91$ & Crossgradient & $x$ \\
\hline RFO-01-581 & Qal & $30-38$ & $83,88,92$ & On-site & $x$ \\
\hline RFO-01-582 & Qal & $21-27$ & $83,85,87,92$ & On-site & $x$ \\
\hline RFO-01-583 & Qal & $25-31$ & $83,90-92$ & On-site & $x$ \\
\hline RFO-01-584 & Qal & $14-29$ & $83,85,87,90,92$ & On-site & $x$ \\
\hline RFO-01-585 & Qal & $13-34$ & 83,87 & On-site & $x$ \\
\hline RFO-01-586 & Qal & $20-33$ & $83,85,87,90-91$ & On-site & $x$ \\
\hline RFO-01-587 & Qal & $14-24$ & 83,92 & On-site & $x$ \\
\hline RFO-01-588 & Qal & $11-18$ & $83,85,87$ & On-site & $x$ \\
\hline RF0-01-589 & Qal & $7-33$ & 83,85 & Downgradient & \\
\hline RFO-01-590 & Qal & $13-30$ & $83,85,87,92-94$ & Downgradient & \\
\hline RFO-01-592 & Qal & - & 91 & Not known & $\mathrm{x}$ \\
\hline RFO-01-594 & Qal & $22-27$ & 90 & On-site & $x$ \\
\hline RFO-01-597 & Qal & $7-12$ & $85,87,90-94$ & Upgradient & \\
\hline RFO-01-598 & Qal & $15-20$ & $85,87,90,92-94$ & Upgradient & \\
\hline RFO-01-599 & Qal & $7-12$ & $85,90,92$ & Downgradient & \\
\hline RF0-01-600 & Qal & $16-21$ & $85,87,90-94$ & Downgradient & \\
\hline RFO-01-601 & Qal & $6-11$ & $85,87,90-92$ & Downgradient & $x$ \\
\hline RF0-01-602 & Qal & $15-20$ & 85,92 & Downgradient & \\
\hline RFO-01-603 & Qal & $6-11$ & $85,87,90$ & Downgradient & $\mathrm{x}$ \\
\hline RFO-01-604 & Qal & $16-21$ & $85,87,90,92-94$ & Downgradient & \\
\hline RFO-01-605 & Qal & $9-13$ & 94 & Upgradient & \\
\hline RF0-01-606 & Qal & $8-12$ & 94 & Upgradient & \\
\hline RF0-01-542 & WS & $171-221$ & $81-82,87,91$ & Crossgradient & $x$ \\
\hline RFO-01-620 & WS & $32-67$ & $85-87,90,92-94$ & Upgradient & \\
\hline RFO-01-621 & WS & $79-99$ & $86,90,92-94$ & Upgradient & \\
\hline RFO-01-622 & WS & $48-58$ & $86-87,90,92$ & Upgradient & \\
\hline RF0-01-623 & WS & $89-99$ & $86-87,90-94$ & On-site & $x$ \\
\hline RFO-01-624 & WS & $64-74$ & 86,92 & On-site & $x$ \\
\hline RFO-01-625 & WS & $76-96$ & $86-87,90,92$ & Downgradient & \\
\hline RFO-01-626 & WS & $49-59$ & $86-87,90,92$ & Downgradient & \\
\hline
\end{tabular}


Table 2.1 Monitor and private well/spring information for Old and New Rifle, Colorado, sites (Continued)

\begin{tabular}{|c|c|c|c|c|c|}
\hline Location ID & $\begin{array}{c}\text { Unit } \\
\text { screened } \\
\end{array}$ & $\begin{array}{c}\text { Screen } \\
\text { interval }^{\mathbf{a}} \\
\text { (completion }^{\text {depth) }} \\
\end{array}$ & $\begin{array}{c}\text { Date sampled } \\
\text { (year) }\end{array}$ & $\begin{array}{c}\begin{array}{c}\text { Flow } \\
\text { relation }\end{array} \\
\end{array}$ & Decommissioned \\
\hline RFO-01-629 & WS & $161-181$ & 86,92 & Crossgradient & \\
\hline RFO-01-630 & WS & $131-141$ & $86,90,92$ & Crossgradient & \\
\hline RFO-01-640 & WS & $88-98$ & $86,90,92$ & Crossgradient & \\
\hline RFO-01-641 & WS & $59-69$ & $86-87,90,92$ & Crossgradient & \\
\hline RFO-01-645 & WS & $91-111$ & $86-87,90-93$ & Downgradient & \\
\hline RFO-01-436 & ? Private & 72 & $92-93$ & Upgradient & \\
\hline \multicolumn{6}{|l|}{ NEW RIFLE } \\
\hline RFN-01-559 & ? Private & $?$ & 90 & Crossgradient & $x$ \\
\hline RFN-01-560 & ? Private & 130 & 90.91 & Crossgradient & \\
\hline RFN-01-563 & Qal & $18-78$ & 81 & Crossgradient & $x$ \\
\hline RFN-01-564 & Qal & $9-99$ & $81-82$ & Crossgradient & $x$ \\
\hline RFN-01-567 & Qal & $19-79$ & 81 & Crossgradient & $x$ \\
\hline RFN-01-581 & Qal & $19-34$ & $\begin{array}{l}83,85,87,88,90 \\
92\end{array}$ & On-site & $x$ \\
\hline RFN-01-582 & Qal & $9-22$ & 83 & On-site & $x$ \\
\hline RFN-01-583 & Qal & $14: 23$ & $83,85,90-91$ & On-site & $x$ \\
\hline RFN-01-584 & Qal & $71-81$ & $83,88,92$ & On-site & $x$ \\
\hline RFN-01-585 & Qal & $9-47$ & 83,87 & Crossgradient & $x$ \\
\hline RFN-01-586 & Qal & $59-66$ & 83 & On-site & $x$ \\
\hline RFN-01-587 & Qal & $64-71$ & $83,88,92-93$ & On-site & $x$ \\
\hline RFN-01-588 & Qal & $7-50$ & $83,85,87,90$ & On-site & $x$ \\
\hline RFN-01-589 & Qal & $8-40$ & $83,87,93-94$ & Downgradient & $x$ \\
\hline RFN-01-590 & Qal & $10-41$ & $83,85,87,92-94$ & Downgradient & $x$ \\
\hline RFN-01-591 & Qal & $8-13$ & 85,87 & Upgradient & $x$ \\
\hline RFN-01-592 & Qal & $17-22$ & $85,87-88,90,92$ & Upgradient & $x$ \\
\hline RFN-01-593 & Qal & $12-17$ & $85,90,92$ & On-site & $x$ \\
\hline RFN-01-594 & Qal & $18-23$ & $85,87,90,92$ & On-site & $x$ \\
\hline RFN-01-595 & Qal & $8-23$ & $85,87,92$ & On-site & $x$ \\
\hline RFN-01-596 & Qal & $8-13$ & $85,90,92-94$ & Downgradient & \\
\hline RFN-01-598 & Qal & $6-11$ & $85,90,92-94$ & Downgradient & \\
\hline RFN-01-599 & Qal & $12-17$ & $85,87,90-91,93$ & Downgradient & \\
\hline RFN-01-600 & Qal & $12-17$ & $\begin{array}{l}85,87,90-91 \\
93-94\end{array}$ & Downgradient & \\
\hline RFN-01-601 & Qal & $7-12$ & 85 & Downgradient & \\
\hline
\end{tabular}


Table 2.1 Monitor and private well/spring information for Old and New Rifle, Colorado, sites (Continued)

\begin{tabular}{|c|c|c|c|c|c|}
\hline Location ID & $\begin{array}{c}\text { Unit } \\
\text { screened }\end{array}$ & $\begin{array}{c}\text { Screen } \\
\text { interval }^{\circ} \\
\text { (completion } \\
\text { depth) }\end{array}$ & $\begin{array}{c}\text { Date sampled } \\
\text { (year) }\end{array}$ & $\begin{array}{l}\text { Flow } \\
\text { relation }\end{array}$ & Decommissioned \\
\hline RFN-01-602 & Qal & $6-11$ & 85 & Downgradient & \\
\hline RFN-01-603 & Qal & $18-23$ & $85,87,90-94$ & Downgradient & \\
\hline RFN-01-605 & Qal & $20-25$ & 85 & Downgradient & \\
\hline RFN-01-609 & Qal & $8-23$ & $85,87,90-94$ & Downgradient & \\
\hline RFN-01-610 & Qal & $5-35$ & $85,87,90-91$ & On-site & $x$ \\
\hline RFN-01-615 & Qal & $9-29$ & 85,87 & On-site & $x$ \\
\hline RFN-01-616 & Qal & $10-20$ & $85,87,90-92$ & On-site & \\
\hline RFN-01-618 & Qal & $18-23$ & $85,87,90-92$ & Downgradient & \\
\hline RFN-01-619 & Qal & $8-13$ & $85,90,92-94$ & On-site & \\
\hline RFN-01-620 & Oal & $7-12$ & 94 & Downgradient & \\
\hline RFN-01-565 & WS & $119-170$ & $81-82$ & Crossgradient & $\mathrm{x}$ \\
\hline RFN-01-611 & WS & $32-47$ & $85-87,90-94$ & On-site & \\
\hline RFN-01-612 & WS & $54-69$ & $85-87,90-93$ & On-site & \\
\hline RFN-01-613 & WS & $28-71$ & $85-87,90-91$ & On-site & \\
\hline RFN-01-614 & WS & $32-34$ & $85-86,90$ & On-site & $x$ \\
\hline RFN-01-621 & WS & $99-119$ & $86-87,90,92$ & Downgradient & \\
\hline RFN-01-622 & WS & $54-59$ & $86-87,90,92-94$ & Downgradient & \\
\hline RFN-01-623 & WS & $46-66$ & $85-87$ & On-site & \\
\hline RFN-01-624 & WS & $29-39$ & $85-87,90,92,94$ & On-site & \\
\hline RFN-01-625 & WS & $91-101$ & $85-87,90,92$ & On-site & $x$ \\
\hline RFN-01-626 & WS & $67-77$ & 86 & On-site & $x$ \\
\hline RFN-01-627 & WS & $67-86$ & $85-87,90,92$ & On-site & \\
\hline RFN-01-628 & WS & $93-113$ & $85-86,92$ & On-site & $x$ \\
\hline RFN-01-629 & WS & $45-55$ & $85-87,90,92$ & On-site & \\
\hline RFN-01-630 & WS & $69-89$ & $86-87,90,92$ & Downgradient & \\
\hline RFN-01-631 & WS & $47-57$ & $86-87,90,93-94$ & Downgradient & \\
\hline RFN-01-633 & WS & $63-73$ & $86,90,92-94$ & Crossgradient & \\
\hline RFN-01-634 & WS & $41-51$ & $86-87,90,92$ & Crossgradient & \\
\hline RFN-01-640 & WS & $132-152$ & $86-87,90,92$ & Crossgradient & \\
\hline RFN-01-641 & WS & $72-82$ & $86-87,90-94$ & Crossgradient & \\
\hline RFN-01-642 & WS & $73-93$ & $86-87,90-92$ & Downgradient & \\
\hline RFN-01-643 & WS & $60-70$ & 86,93 & Downgradient & \\
\hline RFN-01-644 & WS & $86-96$ & $86,90,92$ & Crossgradient & \\
\hline RFN-01-645 & WS & $61-71$ & $86-87,90-93$ & Crossgradient & \\
\hline
\end{tabular}


Table 2.1 Monitor and private well/spring information for Old and New Rifle, Colorado, sites (Concluded)

\begin{tabular}{|c|c|c|c|c|c|}
\hline Location ID & $\begin{array}{c}\text { Unit } \\
\text { screened }\end{array}$ & $\begin{array}{c}\text { Screen } \\
\text { interval }^{\circ} \\
\text { (completion }^{\text {depth) }} \\
\end{array}$ & $\begin{array}{c}\text { Date sampled } \\
\text { (year) }\end{array}$ & $\begin{array}{c}\text { Flow } \\
\text { relation }\end{array}$ & Decommissioned \\
\hline RFN-01-646 & WS & $121-141$ & $86-87,90$ & Upgradient & \\
\hline RFN-01-647 & WS & $59-74$ & $86-87,90,92-93$ & Upgradient & \\
\hline RFN-01-650 & WS & $84-94$ & $86,90,92-94$ & Downgradient & \\
\hline RFN-01-651 & WS & $55-65$ & $86-87,90$ & Downgradient & \\
\hline RFN-01-421 & ? Private & 25 & $91-94$ & Upgradient & \\
\hline RFN-01-422 & ? Private & 160 & $91-92,94$ & Upgradient & \\
\hline RFN-01-423 & ? Private & 20 & $91-94$ & Upgradient & \\
\hline RFN-01-424 & ? Private & 60 & $91-94$ & Upgradient & \\
\hline RFN-01-425 & ? Private & 65 & $91-93$ & Upgradient & \\
\hline RFN-01-426 & D-WS?-Spg & NA & $91-94$ & Upgradient & \\
\hline RFN-01-427 & ? Private & 68 & $91-92$ & Crossgradient & \\
\hline RFN-01-428 & ? Qal & 30 & $91-94$ & Downgradient & \\
\hline RFN-01-430 & ? Private & $?$ & $91-92,94$ & Upgradient & \\
\hline RFN-01-431 & ? Private & 80 & $91-92,94$ & Upgradient & \\
\hline RFN-01-432 & ? Private & 55 & $91-92,94$ & Upgradient & \\
\hline RFN-01-433 & D-WS?-Spg & NA & 94 & upgradient & \\
\hline RFN-01-435 & D-WS?-Spg & NA & 94 & Upgradient & \\
\hline
\end{tabular}

"Feet below the surface.

Qal - alluvium.

WS - Wasatch Formation.

? - Well screened and completed at an unknown depth.

D-WS?-Spg - Private spring in Wasatch Formation or Wasatch colluvium.

$?$ Private - Private well likely completed in the Wasatch Formation.

$\mathrm{X}$ - decommissioned.

NA - not applicable.

Dash indicates data are not available. 


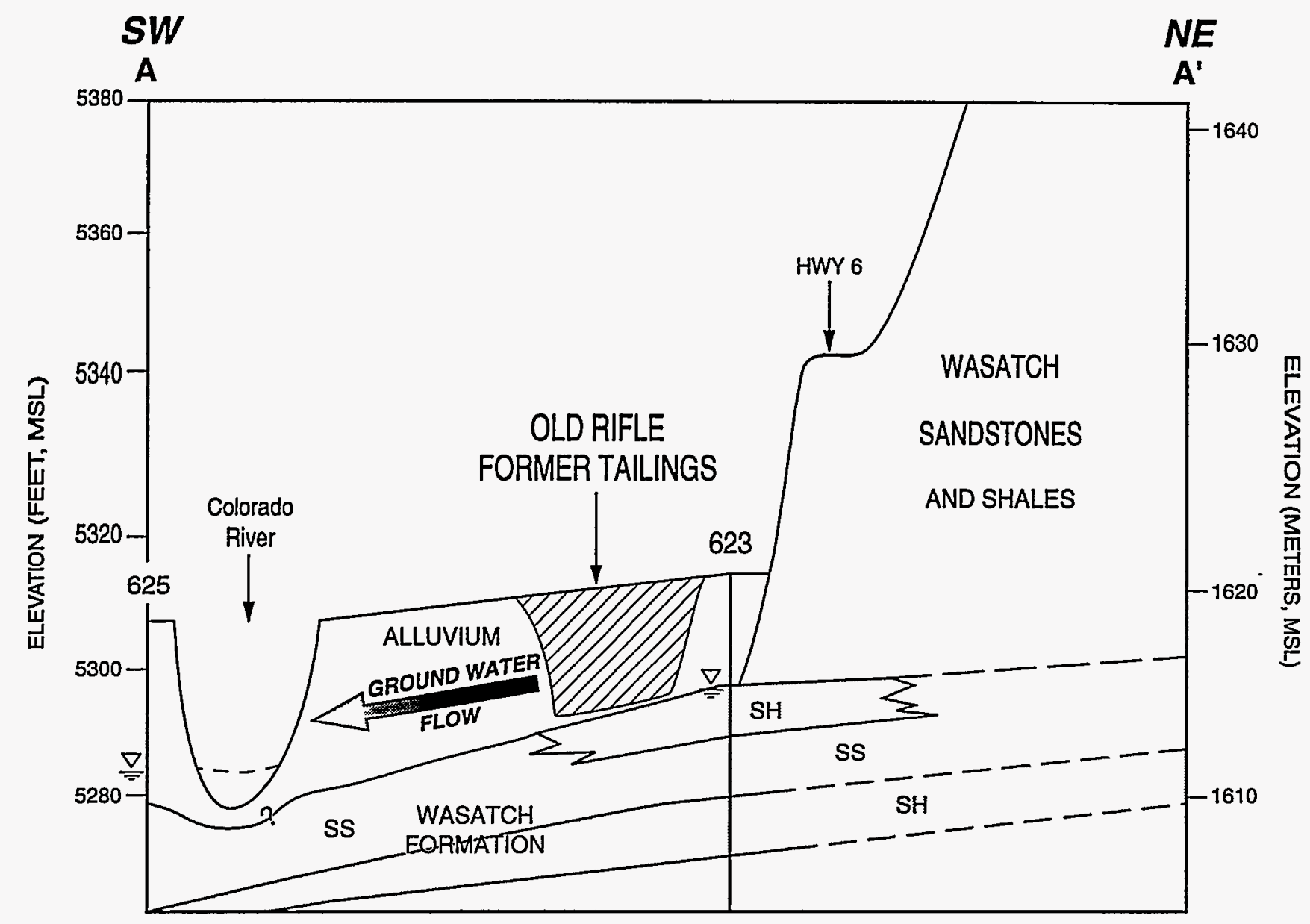

\section{LEGEND}

SS WASATCH/SANDSTONE

SH WASATCH/SHALE

$\begin{array}{ll}\nabla & \text { POTENTIOMETRIC SURFACE } \\ & \text { OF WASATCH FORMATION (APRIL 1989) }\end{array}$

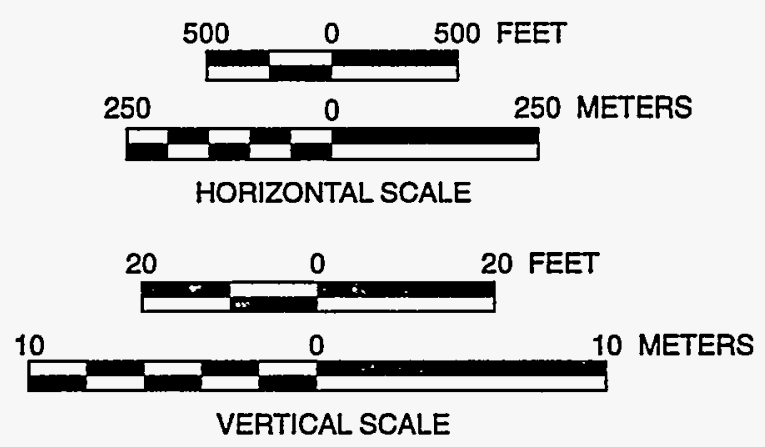

FIGURE 2.8

GENERALIZED GEOLOGIC CROSS SECTION A-A' (SOUTHWEST TO NORTHEAST) OLD RIFLE, COLORADO, SITE 
alluvium composed of dark brown, clayey or silty sands. Profile A-A' also shows the top of the Wasatch Formation and bedding slopes south toward the Colorado River.

At New Rifle, the alluvium was deposited in a broad floodplain over the Wasatch Formation. A short distance north of Highway 6, the alluvium pinches out and merges into Wasatch colluvium.

New Rifle cross section profile A-A' (Figures 2.7 and 2.9) shows that the bedrock surface and bedding of the weathered Wasatch Formation dip southwest. The upper beds of the Wasatch Formation are composed of weathered sandstone and are underlain by shale.

The deeper beds of the Wasatch Formation near the former Rifle processing sites consist of over $2000 \mathrm{ft}(600 \mathrm{~m})$ of interbedded shales and lenticular sandstone units dipping 5 to 10 degrees west-southwest. The upper Shire Member is $1600 \mathrm{ft}(500 \mathrm{~m})$ thick near Rifle and consists of variegated claystones, siltstones, and lenticular sandstones (DOE, 1992a).

\section{$2.5 \quad$ HYDROGEOLOGY}

This section presents information relative to regional and on-site ground water flow to provide supporting data for discussion of background water quality and on-site and downgradient contaminant distribution.

\subsubsection{Regional hydrogeology}

Regional ground water flow north of the Rifle sites is complex due to structural, topographical, and geological variation. Little detailed information is available on the hydrogeologic systems within the region surrounding Rifle. Figure 2.4 approximates the limit of the regional drainage boundary. The White River uplift and Grand Hogback are in the zone of regional recharge while the Colorado River and vicinity are in the zone of regional discharge. The hydrologic drainage basin north of the Rifle sites (Figure 2.4) has well defined local relief. As evidenced by features such as the Colorado River and numerous creeks and springs, many different flow systems discharge toward the river in the vicinity of the Rifle sites. Ground water flow paths are longer in regional and intermediate ground water flow systems than in local systems. The degree of ground water mineralization is a function of both the initial water chemistry and the length of time the water is in contact with the various rock types along its flow path. The numerous flow systems, with varying flow path depths and lengths within the interbedded shales and sandstones of the Wasatch Formation, cause variations in ground water quality in the Rifle area.

\subsubsection{Old and New Rifle site hydrogeology}

The Old and New Rifle processing sites are underlain by two water-bearing hydrogeologic units: a shallow unconfined aquifer in the alluvium lining the 


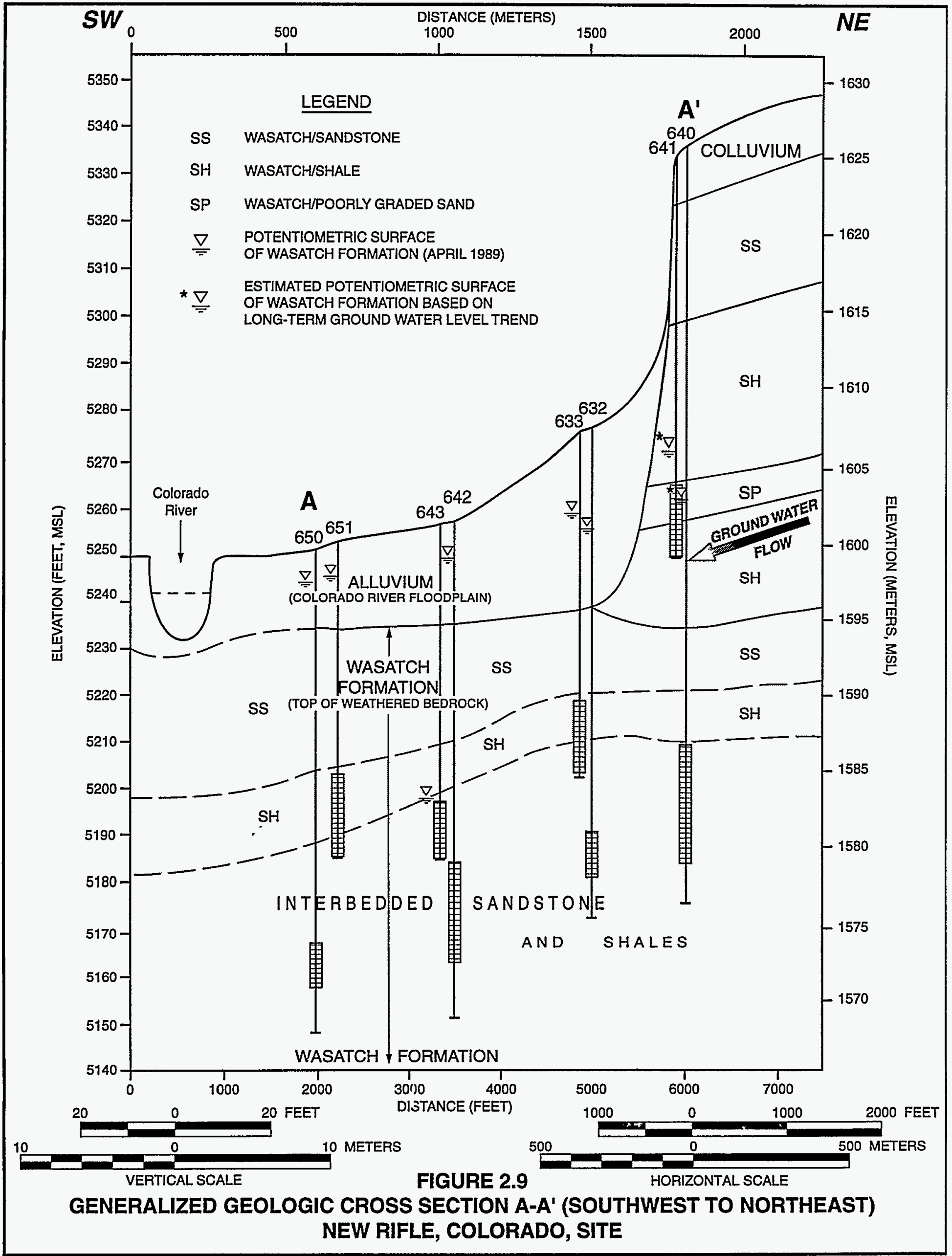


Colorado River and a semiconfined aquifer in the Wasatch Formation bedrock beneath the alluvium. In contrast to the Old Rifle site, New Rifle alluvial sediments are deposited in a broad floodplain that extends several miles downgradient. The upper Wasatch Formation at both sites is fractured due to weathering. Although it has a lower hydraulic conductivity, it is in direct hydraulic contact with the alluvium. Therefore, the upper Wasatch and the alluvium are sometimes indistinguishable when ground water quality and ground water level data are analyzed.

The alluvium at both sites is recharged by precipitation, regional ground water flow from upgradient water-bearing beds of the Wasatch Formation, and return irrigation flow. The Old Rifle site may also be recharged locally by the upgradient lagoons on Graham Mesa. Seasonal fluctuations in the Colorado River recharge the alluvium locally when the river is high. The Colorado River is a regional drainage divide for the alluvial aquifer and upper Wasatch Formation at both sites.

Ground water in the alluvium and Wasatch Formation at the Old and New Rifle sites flows southwest and discharges to the river. The horizontal hydraulic gradient in the alluvial aquifer and in the upper Wasatch Formation ranges from 0.002 to 0.006 feet per foot $(\mathrm{ft} / \mathrm{ft}$ ) (DOE, 1992a). During times of high river stage, ground water flow near the river probably tends to parallel the river. When the river is low, allüvial ground water discharges to the Colorado River. Ground water levels generally fluctuate from 2 to $5 \mathrm{ft}(0.6$ to $1.5 \mathrm{~m})$ annually. Figures 2.10 and 2.11 are contour maps of the water table for the alluvial aquifer and potentiometric surface of the Wasatch Formation for the Old and New Rifle sites. The maps show there is little apparent variation in horizontal hydraulic gradient across the site. Ground water flow directions and gradients are better documented near the New Rifle tailings.

DOE has monitored ground water levels within a network of seven New Rifle alluvial well points since 1989 (Figure 2.11). Measurements are collected biweekly. These data indicate a relatively constant horizontal hydraulic gradient toward the southwest in the immediate vicinity of the New Rifle tailings, regardless of the stage of the Colorado River. Ground water levels measured by DOE in New Rifle Wasatch monitor wells along profile A-A' (Figure 2.9) also show that ground water flows southwest and that ground water from upgradient Wasatch Formation beds recharges the alluvium along the northern boundary of the New Rifle site. All available water level data indicate there is no potential for ground water flow from the New Rifle processing site toward private wells north of Highway 6 (last of the former tailings pile).

In general, there are small-to-no downward vertical gradients at the Rifle sites from the alluvial aquifer to the upper weathered Wasatch Formation because these units are hydraulically connected. At the Old Rifle site, the alluvial aquifer is surrounded due to seepage from lagoons north of Highway 6 . Ground water levels from several Wasatch Formation well clusters indicate vertical gradients deeper within the Wasatch Formation are complex. For example, New Rifle 


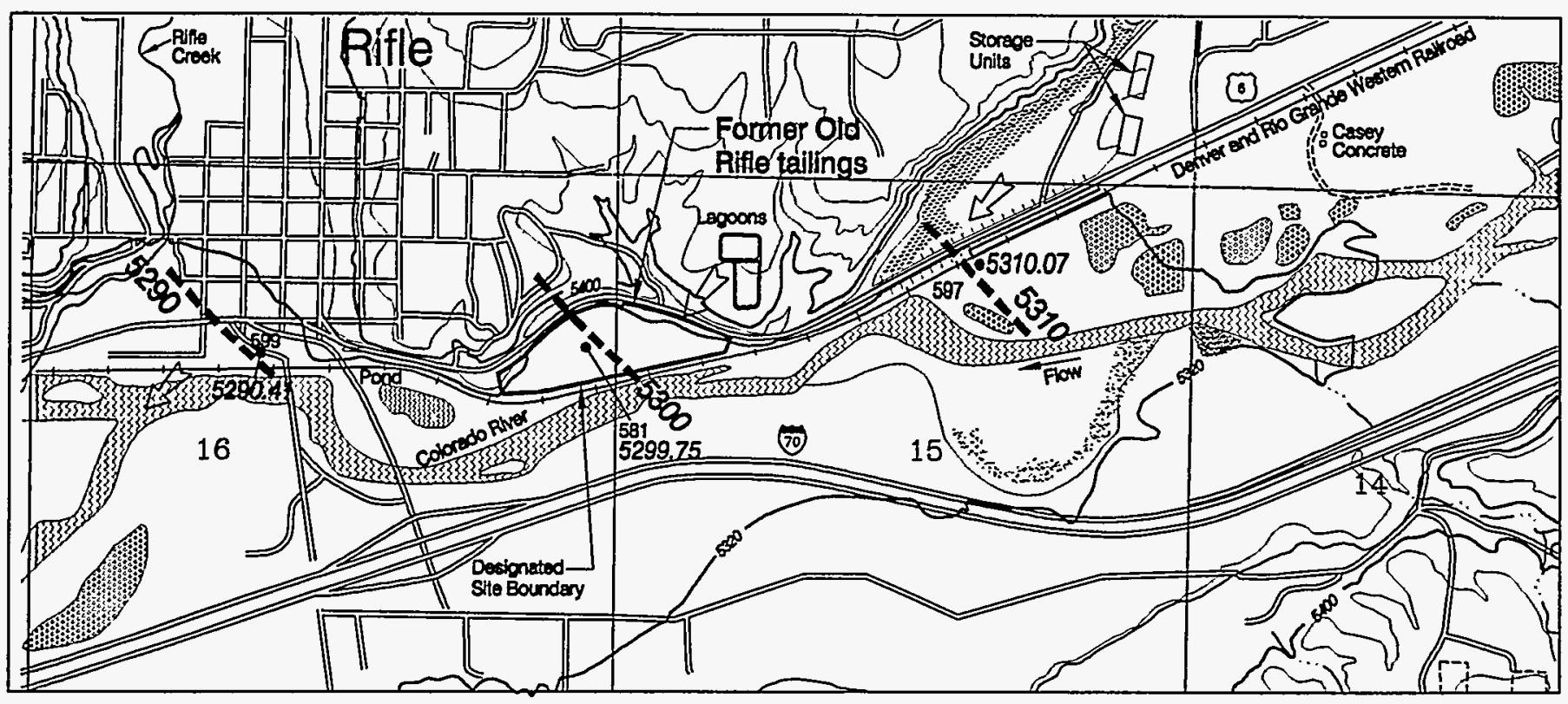

FIGURE 2.10a

WATER TABLE CONTOUR MAP OF THE ALLUVIAL AQUIFER OLD RIFLE, COLORADO, PROCESSING SITE VICINITY
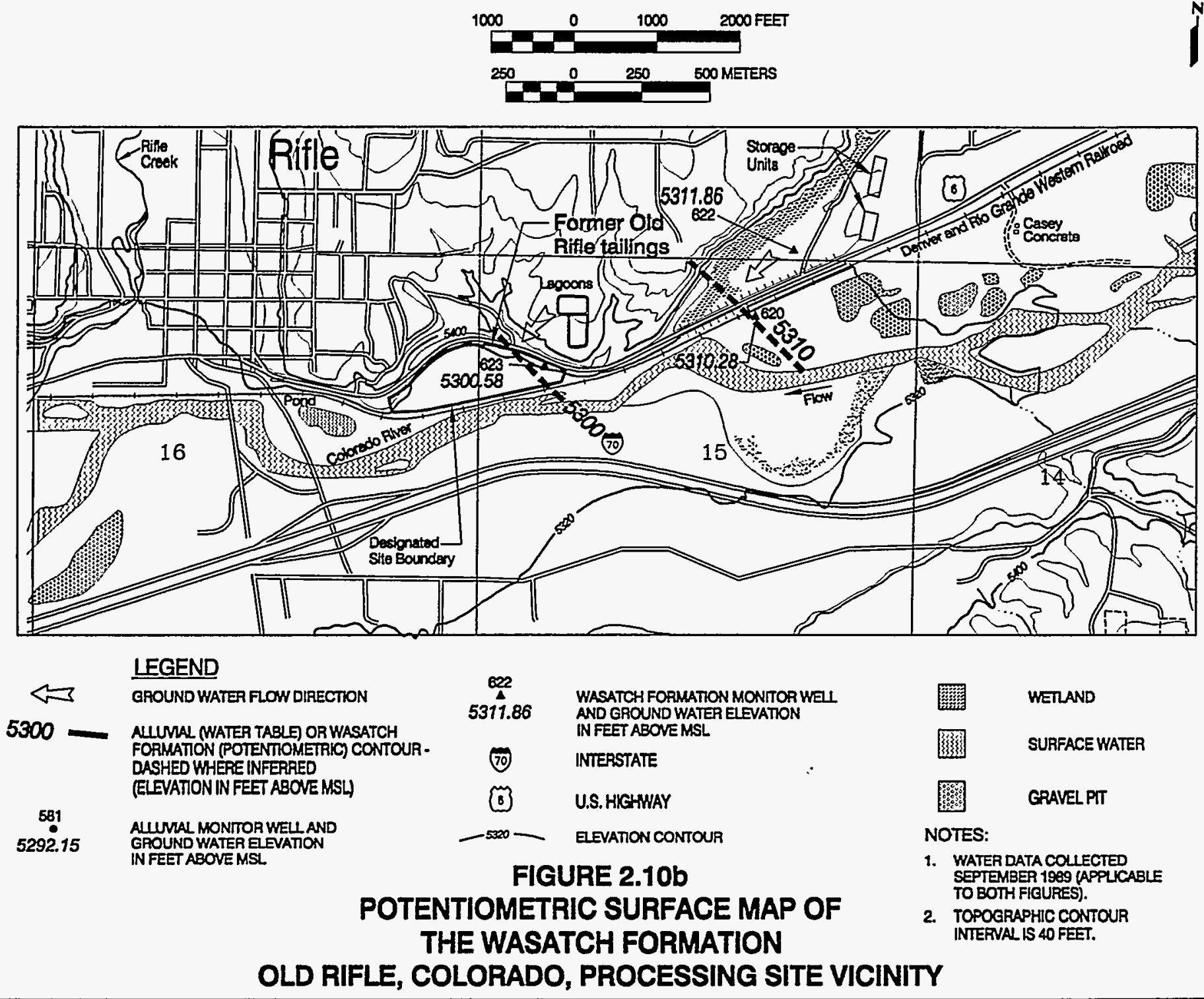


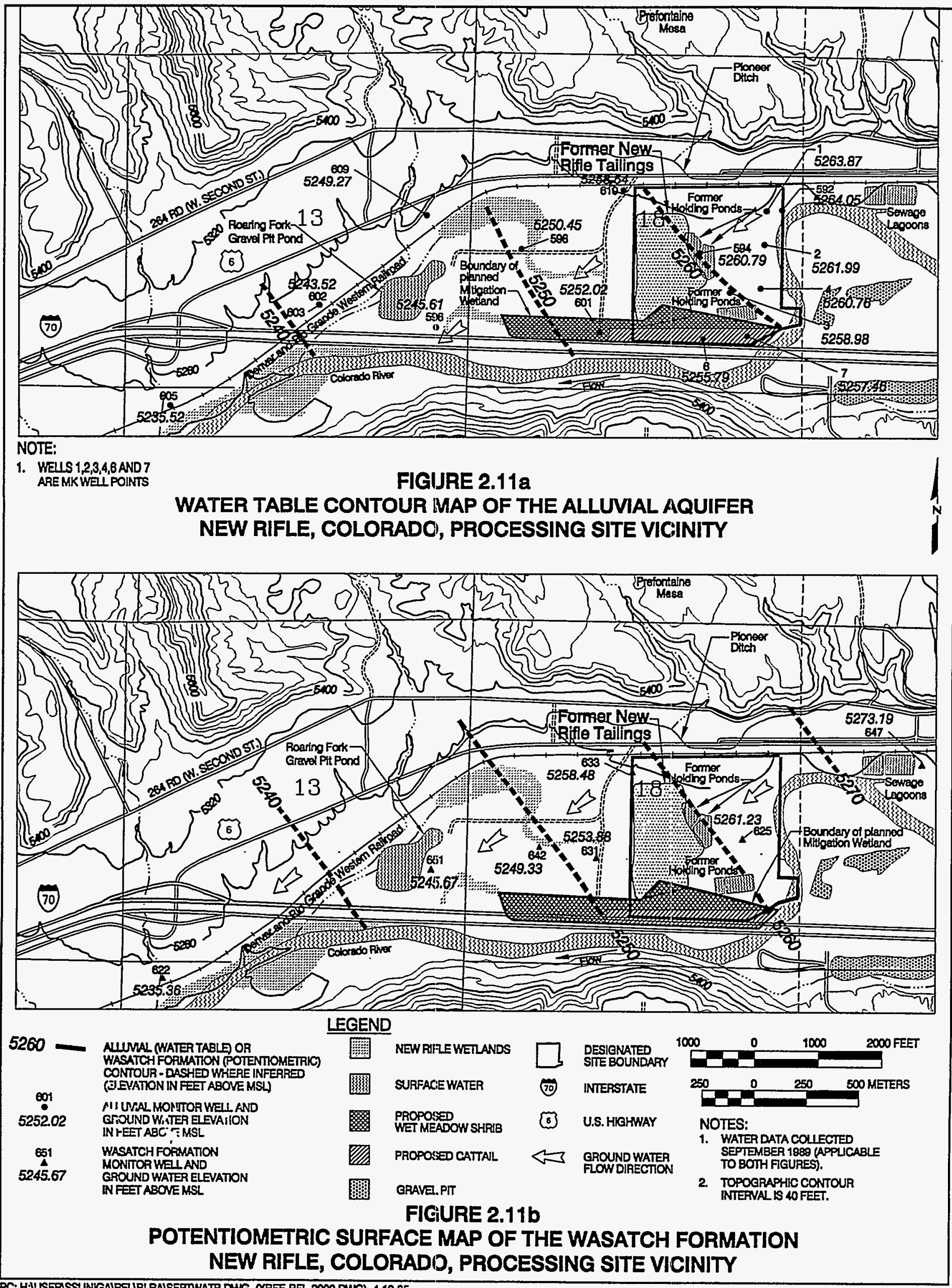


Wasatch monitor wells RFN-01-0640 and -0641 (Figure 2.9) are very near each other yet ground water levels measured in well 641 are consistently about $10 \mathrm{ft}$ $(3 \mathrm{~m})$ higher. Well 641 is $86.5 \mathrm{ft}(26.4 \mathrm{~m})$ deep and is screened from approximately 70 to $80 \mathrm{ft}(21$ to $24 \mathrm{~m})$. Well 640 is $160 \mathrm{ft}(49 \mathrm{~m})$ deep and is screened from about 131 to $151 \mathrm{ft}(40$ to $46 \mathrm{~m})$. The elevated ground water levels observed in well 641 probably are a result of water flowing downdip along bedding of a lower hydraulic conductivity. The occurrence of springs along Wasatch bluffs in the vicinity of these wells supports this observation. Further south, downgradient from the New Rifle tailings site, ground water levels from Wasatch Formation well cluster RFN-01-0642 and -0643 (completed

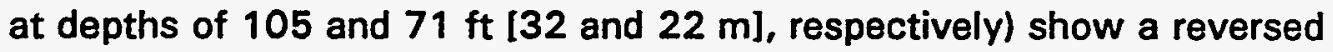
relationship. In this case, the deeper well (642) consistently shows a ground water elevation that is approximately $50 \mathrm{ft}(15 \mathrm{~m})$ higher than in shallower well 643. Ground water level measurements from well 642 are consistent with levels from most other Wasatch wells. Therefore, it is believed to exhibit the dominant potentiometric surface of the Wasatch Formation near New Rifle. Well RFN-01-0643 may be completed in an aquitard. Water levels observed in well RFN-01-0626 (screened form 66 to $76 \mathrm{ft}$ [20 to $23 \mathrm{~m}$ ] just east of the former New Rifle tailings pile also indicate a much lower potentiometric surface than nearby Wasatch wells. This supports the assumed presence of an aquitard or separate flow system at a relatively shallow depth across the site. Further downgradient of the New Rifle tailings, wells RFN-01-0650 and -0651 (completed at 102 and $65 \mathrm{ft}$ [31 and $20 \mathrm{~m}$ ], respectively) respond similarly to fluctuations in ground water levels. Ground water quality results from the Wasatch well clusters indicate deeper wells are screened in a flow system in which chloride and total dissolved solids (TDS) tend to be elevated, whereas shallow wells are screened in a system in which sulfate and uranium levels tend to be elevated.

The analysis of ground water level trends and ground water quality indicates the presence of a least four flow systems in the vicinity of the New Rifle site. The uppermost flow system (north of the site) consists predominantly of springs that discharge along the Wasatch Formation bedding surface. The second is the alluvial aquifer and weathered Wasatch system. The third is a lower permeability aquitard. The fourth consists of semiconfined sandstones and shales. The flow systems in the vicinity of the Rifle sites will be further defined in the site observational work plan.

Limited test data indicate that hydraulic conductivities at the Old Rifle site average 200 feet per day (ft per day) $\left(7 \times 10^{-2}\right.$ centimeters per second $\left.[\mathrm{cm} / \mathrm{s}]\right)$ in the alluvium and $0.02 \mathrm{ft}$ per day $\left(7 \times 10^{-6} \mathrm{~cm} / \mathrm{s}\right)$ in the Wasatch Formation. Average linear ground water velocities are approximately $800 \mathrm{ft}(300 \mathrm{~m})$ per year in the alluvium and $3 \mathrm{ft}(0.9 \mathrm{~m})$ per year in the Wasatch Formation. Less than $500 \mathrm{ft}(150 \mathrm{~m})$ southwest of the Old Rifle site, within the narrow floodplain between the Colorado River and the Old Rifle site, an outcrop of Wasatch bedrock slows ground water flow and its relatively low hydraulic conductivity forces the flow toward the river. Although ground water flow is impeded downgradient of Old Rifle, a narrow deposit of alluvial material remains 
that could transmit ground water westward if it were saturated when the river is high.

At the New Rifle site, hydraulic conductivities average $70 \mathrm{ft}$ per day $\left(2.5 \times 10^{-2} \mathrm{~cm} / \mathrm{s}\right)$ in the alluvium and $0.09 \mathrm{ft}$ per day $\left(3.2 \times 10^{-5} \mathrm{~cm} / \mathrm{s}\right)$ in the Wasatch Formation. Average linear ground water velocities are approximately $300 \mathrm{ft}(90 \mathrm{~m})$ per year in the alluvium and $3 \mathrm{ft}(0.9 \mathrm{~m})$ per year in the Wasatch Formation. The limited nature of the test data, the heterogenous nature of alluvial deposits, and the sensitivity of the ground water velocity to various parameters may cause considerable variations in actual linear ground water flow velocities at both the Old and New Rifle sites. The large difference between average linear ground water flow velocities at the Rifle sites indicates a broad range in hydraulic conductivity. This range will be defined further in the site observational work plan.

\subsection{SURFACE WATER HYDROLOGY}

This section presents information relative to regional and on-site surface water flow to provide supporting data for discussion of background water quality and on-site and downgradient distribution of contaminants.

North of Rifle, the steeply tilted Grand Hogback monocline rises to an elevation of $8000 \mathrm{ft}(2400 \mathrm{~m})$, redirecting surface drainage from the steep-walled canyon and the mountain region of the White River Plateau to the broad flat valleys of the Colorado River Basin. The area just north of Rifle is drained locally by Rifle Creek, Elk Creek, and Government Creek. The area is drained regionally by the Colorado River (Figure 2.4).

The main channel of the Colorado River at the Old Rifle site is within $75 \mathrm{ft}$ $(23 \mathrm{~m})$ of the former tailings pile and was separated from the tailings pile by a railroad embankment. At New Rifle, the floodplain is much broader. Near New Rifle, the main channel of the Colorado River has been artificially channeled to the north by blocking alternative river channels upstream of the site. The Colorado River is about $1000 \mathrm{ft}(310 \mathrm{~m})$ east and $600 \mathrm{ft}(200 \mathrm{~m})$ south of the tailings pile. Interstate 70 is between the New Rifle site and the Colorado River.

Several additional surface water features near the Rifle sites are seeps, springs, irrigation ditches, and ponds. Surface water and sediment sampling locations are shown in Figure 2.12. Table 2.2 gives a sampling history of surface locations. Numerous seeps and springs, many at Wasatch bedding and colluvium interfaces along the southern cliff faces of Prefontaine and Graham Mesas, are found north of the Rifle sites. The seeps discharge seasonally, often surrounding the point of discharge with precipitated salts. Springs provide water throughout the year. Thre ? private springs that have been sampled (RFN-01-0426, -0433, and -0.4.3r) are north of Highway 6 near the New Rifle processing site and several additional springs are apparent northeast of the Old Rifle site. Discharge from the springs near Old Rifle drains into what is referred to as One Mile Pond (Figure 2.12). One spring upgradient from One Mile Pond 

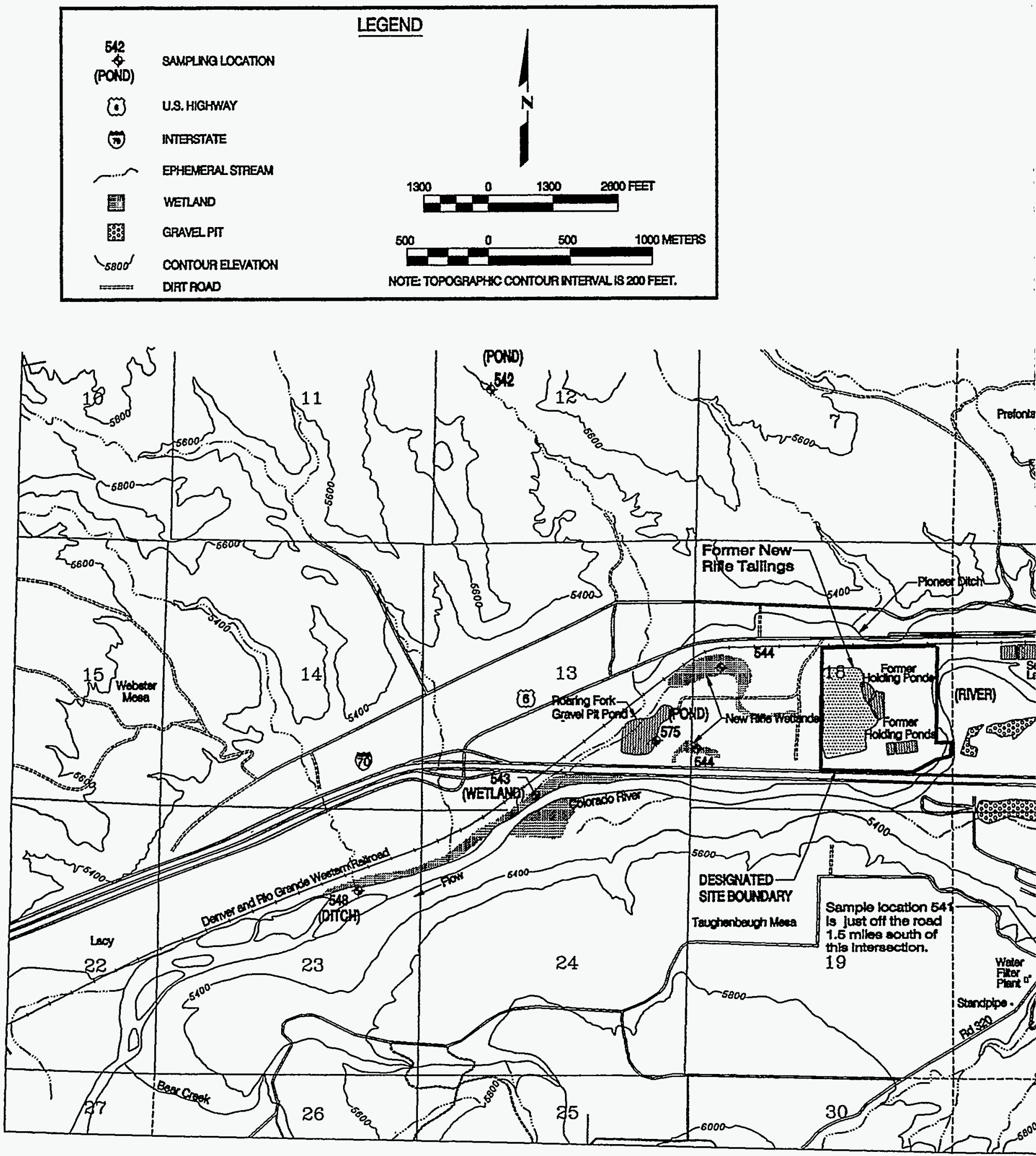
Table 2.2 Surface water/sediment sample location information for Old and New Rifle, Colorado, sites

\begin{tabular}{|c|c|c|c|}
\hline Location ID & Description & $\begin{array}{c}\text { Date sampled } \\
\text { (year) }\end{array}$ & Flow relation \\
\hline \multicolumn{4}{|l|}{ Old Rifle } \\
\hline RFO-01-0583 & Colorado River & $87,91,94$ & Upgradient \\
\hline RFO-01-0568 & Pioneer Ditch & 1994 & Upgradient \\
\hline RFO-01-0569 & Rifle Creek & 1994 & Upgradient \\
\hline RFO-01-0570 & One Mile Pond & 1994 & Upgradient \\
\hline RFO-01-0572 & Old Rifle Pond & $1989-1994$ & Upgradient \\
\hline RFO-01-0573 & One Mile Spring & 1994 & Upgradient \\
\hline RFO-01-0574 & E. Rifle Creek & 1994 & Upgradient \\
\hline \multicolumn{4}{|l|}{ New Rifle } \\
\hline RFN-01-0541 & Helmer Gulch & 94 & Upgradient \\
\hline RFN-01-0542 & Pond NW of New Rifle & 94 & Upgradient \\
\hline RFN-01-0544 & Wetland & 94 & Downgradient \\
\hline RFN-01-0545 & Colorado River & $87,91,93,94$ & Upgradient \\
\hline RFN-01-0548 & Colorado River & 91,94 & Downgradient \\
\hline RFN-01-0575 & $\begin{array}{l}\text { Roaring Fork gravel pit } \\
\text { pond }\end{array}$ & $91,92,93,94$ & Downgradient \\
\hline RFN-01-0576 & Wetland & $91,92,94$ & Downgradient \\
\hline
\end{tabular}


(surface location RF0-01-0573) discharges along the interface of Wasatch bedrock and the overlying colluvium at a rate of about 30 gallons per minute. Some of the water flowing from these regional discharge features may have originated far to the north as snowmelt.

An extensive ditch irrigation system exists in the vicinity of the Rifle sites. Many of the ditch systems originate from Rifle Creek and are used to distribute water for agricultural purposes on Graham and Prefontaine Mesas (Figures 2.2 and 2.3). Pioneer Ditch, north of the New Rifle site, flows from Rifle Creek parallel to Highway 6 and extends west of the processing site (Figure 2.12).

Other significant surface water features in the vicinity of the Rifle sites are the Old Rifle Pond downgradient from the site; lagoons on Graham Mesa upgradient from Old Rifle; the Roaring Fork gravel pit pond, approximately $4800 \mathrm{ft}$ $(1500 \mathrm{~m})$ west of the New Rifle site; and two city of Rifle sewage lagoons, south of Highway 6 about $4000 \mathrm{ft}(1200 \mathrm{~m})$ east of the New Rifle site (Figure 2.12).

Several drainages relevant to this baseline risk assessment, including Bear Creek and Helmer Gulch, are south of the River (Figure 2.12).

\subsection{LAND USE}

The city of Rifle (population approximately 4600) is in Garfield County, Colorado. The town consists of businesses, industrial areas, and residential neighborhoods (DOC, 1991). The Old and New Rifle former processing sites are just outside the Rifle city limits (Figure 2.1).

The sites and the properties adjacent to both sites are not annexed by the city of Rifle but are under the jurisdiction of Garfield County. These areas are zoned for both industrial and agricultural uses. This zoning classification allows residential development on a 2-ac (0.8 ha) (minimum) lot. Industrial use requires special approval by the country and is limited to activities associated with natural resource extraction, (e.g., the existing gravel pits). The city's long-term master plan is to annex these areas and commercially develop the area from the New Rifle.site west to the Interstate 70 entrance ramp. Plans will be negotiated for future development of land being remediated under UMTRCA and the land will be returned to the community.

There are no residences adjacent to either site. The residential areas nearest to the former processing sites are within $1 \mathrm{mi}(1.6 \mathrm{~km})$ and upgradient from the sites, north across Highway 6.

Both sites are within the 100-year floodplain. A pond on private property, referred tr. is the Old Rifle pond, is west of the Old Rifle site. Old Rifle pond is known to be used by trespassers for recreation such as fishing and swimming. Ranching is the main industry on Prefontaine and Graham Mesas, north of New Rifle. 
Residents in the city of Rifle receive water from the municipal water system, which receives surface water from the Colorado River and Bear Creek. Water from the Colorado River is collected at an inlet approximately $0.5 \mathrm{mi}(0.8 \mathrm{~km})$ upstream of the Old Rifle site. Water in Bear Creek originates from Bear Mountain snowmelt and precipitation and is transported into the municipal water supply via a pipeline. Bear Creek supplies approximately 10 percent of the city's water. Water for agriculture is obtained from an extensive surface water ditch system running from the mountain's major tributaries, including Rifle Creek.

The city provides water to some users outside the city limits, though most residents living outside the municipal boundaries obtain water from private wells or springs. Natural ground water quality in the Colorado River alluvium and weathered Wasatch Formation is poor tasting and considered unpotable because of high sulfate and TDS levels (DOE, 1992b). Consequently, the ground water from these private wells and springs generally is not used for drinking water. Ground water is known to be used for other domestic purposes such as bathing, watering domestic livestock, and watering gardens. Ground water and surface water also are used agriculturally to water livestock. Table 2.3 summarizes private well use in the vicinity of the Rifle sites.

Sixteen private wells and springs were monitored as part of the DOE's surface and ground water projects (Figures 2.6 and 2.7). Limited well log information indicates most private wells are probably completed in the colluvium or weathered Wasatch Formation (Table 2.1). Fifteen of these private wells and springs (which have been monitored) are in the vicinity of the New Rifle site. All private wells and springs near the New Rifle site are upgradient or crossgradient from the site, except well RFN-01-0428, which is clearly downgradient. Private well RFO-01-0436 is upgradient of the Old Rifle site. Private well RFN-01-0559 has been decommissioned; residences and businesses supplied by wells RFN-01-0423, -04.32 , and -0560 have been connected to the city water system. 
Table 2.3 Private wells sampled in the vicinity of the Old and New Rifle, Colorado, sites

\begin{tabular}{|c|c|c|}
\hline Well number & Well location & Geographic location \\
\hline RFN-01-0421 & Farmyard & Upgradient of New Rifle, south of Highway 6/east of site \\
\hline RFN-01-0422 & Industrial & Upgradient of New Rifle, south of Highway 6/east of site \\
\hline RFN-01-0423 & Residential & Upgradient of New Rifle, north of Highway $6 / N E$ of site \\
\hline RFN-01-0424 & Industrial & Upgradient of New Rifle, north of Highway 6/NE of site \\
\hline RFN-01-0425 & Industrial & Upgradient of New Rifle, north of Highway $6 /$ NE of site \\
\hline RFN-01-0426 & $\begin{array}{l}\text { Residential } \\
\text { spring }\end{array}$ & Upgradient of New Rifle, north of Highway 6/NE of site \\
\hline RFN-01-0427 & Industrial & $\begin{array}{l}\text { Crossgradient of New Rifle, north of Highway 6/NW of } \\
\text { site }\end{array}$ \\
\hline RFN-01-0428 & Industrial & $\begin{array}{l}\text { Downgradient of New Rifle, south of Highway 6/west of } \\
\text { site }\end{array}$ \\
\hline RFN-01-0430 & Residential & Upgradient of New Rifle, north of Highway 6/NE of site \\
\hline RFN-01-0431 & Residential & Upgraclient of New Rifle, north of Highway $6 /$ NE of site \\
\hline RFN-01-0432 & $\begin{array}{l}\text { Residential } \\
\text { (now on city } \\
\text { water) }\end{array}$ & Upgradient of New Rifle, north of Highway 6/NE of site \\
\hline RFN-01-0433 & $\begin{array}{l}\text { Residential } \\
\text { springbox }\end{array}$ & $\begin{array}{l}\text { Upgradient of New Rifle, north of Highway } 6 / \text { north of } \\
\text { site }\end{array}$ \\
\hline RFN-01-0435 & $\begin{array}{l}\text { Residential } \\
\text { spring }\end{array}$ & $\begin{array}{l}\text { Upgradient of New Rifle, north of Highway 6/north of } \\
\text { site }\end{array}$ \\
\hline RFO-01-436 & Residential & Upgradient of Old Rifle, north of Highway 6/NE of site \\
\hline RFN-01-0559 & Industrial & $\begin{array}{l}\text { Crossgradient of New Rifle, north of Highway 6/NW of } \\
\text { site }\end{array}$ \\
\hline RFN-01-0560 & $\begin{array}{l}\text { Industrial } \\
\text { (now on city } \\
\text { water) }\end{array}$ & $\begin{array}{l}\text { Crossgradient of New Rifle, north of Highway } 6 / \mathrm{NW} \text { of } \\
\text { site }\end{array}$ \\
\hline
\end{tabular}




\subsection{MAGNITUDE AND EXTENT OF CONTAMINATION}

Ground water quality data from the Old and New Rifle processing sites and vicinity were collected from 1981 through 1994. A of total of 114 wells were sampled. In Tables 2.1 and 2.2, these wells are compiled according to hydrogeologic zone of completion (alluvial deposits or Wasatch Formation) and location (Old or New Rifle). Old Rifle wells include 24 DOE monitor wells completed in the alluvium, and 14 DOE monitor wells completed in the Wasatch Formation (Figure 2.6). One private well was sampled at a trailer park upgradient of the site.

At the New Rifle processing site, 34 DOE monitor wells are completed in the alluvium; 29 DOE monitor wells are completed in the Wasatch Formation (Figure 2.7). Twelve private wells associated with the New Rifle site have been sampled. These wells are mostly upgradient or crossgradient (to the northeast or northwest); one private well is $2.7 \mathrm{mi}$ $(4.3 \mathrm{~km})$ downgradient.

Ground water quality data collected from August 1990 through August 1994 are used in this document to characterize the magnitude and extent of contamination and to assess risks. This effort incorporated 4 years of ground water data and represents the most recent information on current conditions. Tables 3.1 and 3.2 summarize the minimum, median, and maximum values found for chemical parameters in the background ground water and contaminated ground water in the alluvium and the Wasatch Formation, respectively. A supplement to this baseline risk assessment contains all data evaluated (TAC, in preparation). Tables 3.1 and 3.2 list all inorganic and radionuclide parameter statistics, except field parameters, and gross alpha and gross beta measurements.

Most water samples drawn from monitor wells at the Rifle sites were filtered prior to water quality analysis. Results are available for only two sampling rounds of unfiltered sample analyses of major site contaminants and indicators. Furthermore, the wells with the highest levels of contamination have no data on unfiltered water samples. However, a comparison of water quality data from pairs of unfiltered and filtered samples collected concurrently indicates manganese, iron, and radium-226 concentrations are consistently higher in unfiltered samples (TAC, in preparation). For the other constituents with available paired data, the unfiltered results typically are more variable but on average are comparable to levels measured in filtered samples.

From 1990 to 1994, ground water quality was monitored for a comprehensive suite of inorganic parameters. In 1990, ground water from the Rifle sites was screened for organic constituents listed in Appendix IX to 40 CFR Part 264. The screening detected toluene (0.018 milligrams per liter [mg/L]) and 2,4,5-T (a defoliant) $(0.005 \mathrm{mg} / \mathrm{L})$ in ground water beneath the tailings pile at the New Rifle site. However, organic constituents are not evaluated in this risk assessment but will be addressed in the site observational work plan.

\subsection{BACKGROUND WATER QUALITY SUMMARY}

Background water quality is defined as the quality of ground water that would exist if uranium milling activities had not occurred. The Old Rifle and New Rifle 
Table 3.1 Summary of ground water quality in the alluvial aquifer, Rifle, Colorado, processing sites, August: 1990 to August 1994, filtered samples

\begin{tabular}{|c|c|c|c|c|c|}
\hline \multirow[b]{2}{*}{ Constituent } & \multirow[b]{2}{*}{ Well ID ${ }^{b}$} & \multirow[b]{2}{*}{$\begin{array}{c}\text { Frequency } \\
\text { of detection" }\end{array}$} & \multicolumn{3}{|c|}{ Observed concentrations } \\
\hline & & & $\begin{array}{l}\text { Minimum } \\
(\mathrm{mg} / \mathrm{L})\end{array}$ & $\begin{array}{l}\text { Median" } \\
\text { (mg/L) }\end{array}$ & $\begin{array}{c}\text { Maximum } \\
(\mathrm{mg} / \mathrm{L})\end{array}$ \\
\hline \multicolumn{6}{|l|}{ Inorganics } \\
\hline \multicolumn{6}{|l|}{ Aluminum } \\
\hline $\begin{array}{l}\text { Background } \\
\text { Old Rifle } \\
\text { New Rifle }\end{array}$ & & $\begin{array}{l}2 / 5 \\
2 / 9 \\
5 / 27\end{array}$ & $\begin{array}{l}<0.05 \\
<0.05 \\
<0.05\end{array}$ & $\begin{array}{l}<0.10 \\
<0.05 \\
<0.05\end{array}$ & $\begin{array}{l}0.14 \\
0.24 \\
0.26\end{array}$ \\
\hline \multicolumn{6}{|l|}{ Ammonium } \\
\hline $\begin{array}{l}\text { Background } \\
\text { Old Rifle } \\
\text { New Rifle }\end{array}$ & $\begin{array}{l}\text { RFO-01-0583 } \\
\text { RFN-01-0583, -0589, } \\
-0590,-0600,-0618\end{array}$ & $\begin{array}{c}8 / 12 \\
5 / 5 \\
19 / 19\end{array}$ & $\begin{array}{c}<0.1 \\
0.8 \\
506\end{array}$ & $\begin{array}{r}0.5 \\
1.4 \\
1030\end{array}$ & $\begin{array}{r}1.5 \\
2.0 \\
1750\end{array}$ \\
\hline \multicolumn{6}{|l|}{ Antimony ${ }^{\circ}$} \\
\hline $\begin{array}{l}\text { Background } \\
\text { Old Rifle } \\
\text { New Rifle }\end{array}$ & & $\begin{array}{c}0 / 5 \\
1 / 9 \\
3 / 25\end{array}$ & $\begin{array}{l}<0.003 \\
<0.003 \\
<0.003\end{array}$ & $\begin{array}{l}<0.003 \\
<0.003 \\
<0.030\end{array}$ & $\begin{array}{r}<0.003 \\
0.007 \\
0.038\end{array}$ \\
\hline \multicolumn{6}{|l|}{ Arsenic } \\
\hline Background & & $2 / 12$ & 0.001 & $<0.005$ & $<0.03$ \\
\hline $\begin{array}{l}\text { Old Rifled } \\
\text { New Rifle }\end{array}$ & $\begin{array}{l}\text { RFO-01-0583 } \\
\text { RFN-01-0594 }\end{array}$ & $\begin{array}{l}5 / 5 \\
2 / 2\end{array}$ & $\begin{array}{l}0.15 \\
0.97\end{array}$ & $\begin{array}{l}0.23 \\
1.1\end{array}$ & $\begin{array}{l}0.24 \\
1.3\end{array}$ \\
\hline \multicolumn{6}{|l|}{ Barium } \\
\hline $\begin{array}{l}\text { Background } \\
\text { Old Rifle } \\
\text { New Rifle }\end{array}$ & & $\begin{array}{c}3 / 5 \\
7 / 9 \\
20 / 27\end{array}$ & $\begin{array}{l}0.03 \\
0.02 \\
0.01\end{array}$ & $\begin{array}{l}0.03 \\
0.03 \\
0.02\end{array}$ & $\begin{array}{l}<0.1 \\
<0.1 \\
<0.1\end{array}$ \\
\hline \multicolumn{6}{|l|}{ Bromide $^{\circ}$} \\
\hline $\begin{array}{l}\text { Background } \\
\text { Old Rifle } \\
\text { New Rifle }\end{array}$ & & $\begin{array}{c}3 / 5 \\
3 / 9 \\
4 / 22\end{array}$ & $\begin{array}{l}<0.1 \\
<0.1 \\
<0.1\end{array}$ & $\begin{array}{r}0.3 \\
<0.4 \\
<1.0\end{array}$ & $\begin{array}{r}0.4 \\
3.0 \\
<3.0\end{array}$ \\
\hline \multicolumn{6}{|l|}{ Cadmium } \\
\hline $\begin{array}{l}\text { Background } \\
\text { Old Rifle } \\
\text { New Rifle }\end{array}$ & $\begin{array}{l}\text { RFN-01-0590, -0595, } \\
-0600,-0619\end{array}$ & $\begin{array}{c}0 / 9 \\
0 / 9 \\
19 / 21\end{array}$ & $\begin{array}{r}<0.001 \\
<0.001 \\
0.002\end{array}$ & $\begin{array}{r}<0.001 \\
<0.001 \\
0.024\end{array}$ & $\begin{array}{r}<0.001 \\
<0.001 \\
0.129\end{array}$ \\
\hline \multicolumn{6}{|l|}{ Calcium } \\
\hline Background & & $15 / 15$ & 93 & 162 & 229 \\
\hline $\begin{array}{l}\text { Old Rifle }^{d} \\
\text { New Rifled }\end{array}$ & (RFN-01-058\%, -0619) & $\begin{array}{c}9 / 9 \\
12 / 12\end{array}$ & $\begin{array}{l}243 \\
401\end{array}$ & $\begin{array}{l}287 \\
462\end{array}$ & $\begin{array}{l}331 \\
514\end{array}$ \\
\hline
\end{tabular}


Table 3.1 Summary of ground water quality in the alluvial aquifer, Rifle, Colorado, processing sites, August 1990 to August 1994, filtered samples (Continued)

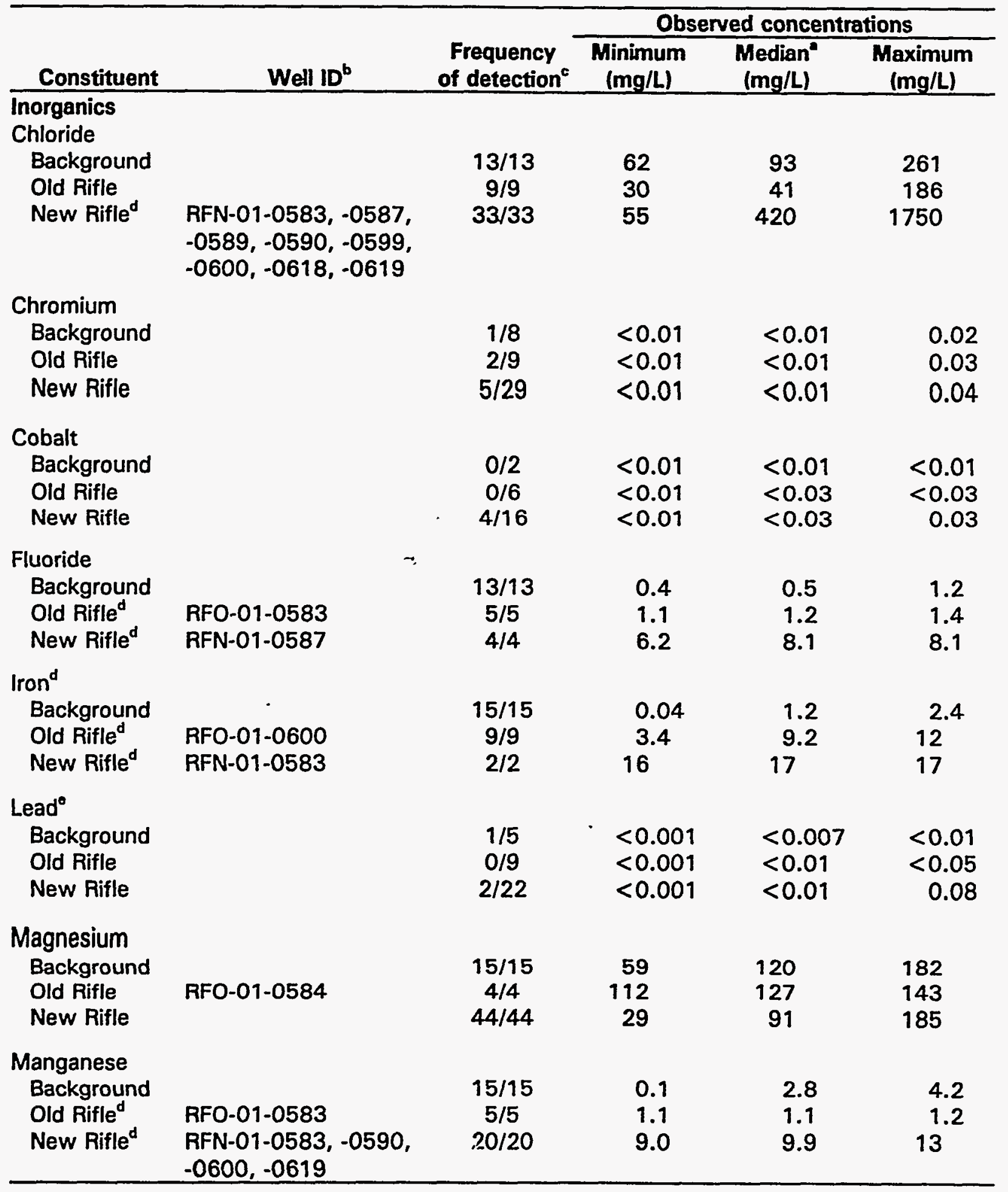


Table 3.1 Summary of ground water quality in the alluvial aquifer, Rifle, Colorado, processing sites, August 1990 to August 1994, filtered samples (Continued)

\begin{tabular}{|c|c|c|c|c|c|}
\hline \multirow[b]{2}{*}{ Constituent } & \multirow[b]{2}{*}{ Well ID } & \multirow[b]{2}{*}{$\begin{array}{c}\text { Frequency } \\
\text { of detection" }\end{array}$} & \multicolumn{3}{|c|}{ Observed concentrations } \\
\hline & & & $\begin{array}{c}\text { Minimum } \\
\text { (mg/L) }\end{array}$ & $\begin{array}{l}\text { Median" } \\
\text { (mg/L) }\end{array}$ & $\begin{array}{c}\text { Maximum } \\
\text { (mg/L) }\end{array}$ \\
\hline Inorganics & & & & & \\
\hline Molybdenum & & & & & \\
\hline $\begin{array}{l}\text { Background } \\
\text { Old Rifled } \\
\text { New Rifled }\end{array}$ & $\begin{array}{l}\text { RFO-01-0583 } \\
\text { RFN-01-0583, }-0587, \\
-0589,-0590,-0619\end{array}$ & $\begin{array}{l}10 / 15 \\
5 / 5 \\
23 / 23\end{array}$ & $\begin{array}{c}<0.01 \\
0.04 \\
2.3\end{array}$ & $\begin{array}{l}0.01 \\
0.10 \\
2.9\end{array}$ & $\begin{array}{l}0.06 \\
0.14 \\
3.7\end{array}$ \\
\hline $\begin{array}{l}\text { Nitrate } \\
\text { Background } \\
\text { Old Rifle } \\
\text { New Rifle }\end{array}$ & RFN-01-0589, -0618 & $\begin{array}{l}5 / 12 \\
7 / 9 \\
7 / 7\end{array}$ & $\begin{array}{l}<0.1 \\
<1.0 \\
552\end{array}$ & $\begin{array}{r}<1.0 \\
1.7 \\
784\end{array}$ & $\begin{array}{r}7.8 \\
5.4 \\
1110^{-4}\end{array}$ \\
\hline $\begin{array}{l}\text { Nickel } \\
\text { Background } \\
\text { Old Rifle } \\
\text { New Rifle }\end{array}$ & & $\begin{array}{l}0 / 2 \\
0 / 2 \\
4 / 5\end{array}$ & $\begin{array}{l}<0.01 \\
<0.01 \\
<0.01\end{array}$ & $\begin{array}{r}<0.01 \\
<0.01 \\
0.03\end{array}$ & $\begin{array}{r}<0.01 \\
<0.01 \\
0.03\end{array}$ \\
\hline $\begin{array}{l}\text { Phosphate }^{\circ} \\
\text { Background } \\
\text { Old Rifle } \\
\text { New Rifle }^{d}\end{array}$ & $\begin{array}{l}\text { RFO-01-0600 } \\
\text { RFN-01-0581, -0583, } \\
-0584,-0587,-0590, \\
-0594,-0595,-0600, \\
-0619\end{array}$ & $\begin{array}{c}1 / 5 \\
3 / 5 \\
12 / 18\end{array}$ & $\begin{array}{l}<0.1 \\
<0.1 \\
<0.1\end{array}$ & $\begin{array}{r}<0.1 \\
0.5 \\
0.2\end{array}$ & $\begin{array}{l}0.1 \\
6.3 \\
7.0\end{array}$ \\
\hline $\begin{array}{l}\text { Potassium } \\
\text { Background } \\
\text { Old Rifle } \\
\text { New Rifle }\end{array}$ & $\begin{array}{l}\text { RFN-01-0599, -0600, } \\
-0618\end{array}$ & $\begin{array}{c}15 / 15 \\
9 / 9 \\
11 / 11\end{array}$ & $\begin{array}{r}3.2 \\
5.8 \\
71\end{array}$ & $\begin{array}{l}5.8 \\
7.0 \\
109\end{array}$ & $\begin{array}{r}12.5 \\
7.4 \\
114\end{array}$ \\
\hline $\begin{array}{l}\text { Selenium } \\
\text { Background } \\
\text { Old Rifle }^{d} \\
\text { New Rifle }\end{array}$ & $\begin{array}{l}\text { RFO-0590 } \\
\text { RFN-01-0581, }-0583 \text {, } \\
-0584,-0587,-0590, \\
-0594,-0595,-0600, \\
-0619\end{array}$ & $\begin{array}{c}3 / 15 \\
5 / 5 \\
14 / 34\end{array}$ & $\begin{array}{r}<0.002 \\
0.007 \\
<0.002\end{array}$ & $\begin{array}{c}<0.005 \\
0.072 \\
<0.05\end{array}$ & $\begin{array}{l}0.013 \\
0.085 \\
0.30\end{array}$ \\
\hline $\begin{array}{l}\text { Silica } \\
\text { Background } \\
\text { Old Rifle } \\
\text { New Rifle }^{d}\end{array}$ & $\begin{array}{l}\text { RFO-01-0583 } \\
\text { RFN-01-0619, -0587 }\end{array}$ & $\begin{array}{c}13 / 13 \\
5 / 5 \\
12 / 12\end{array}$ & $\begin{array}{l}17 \\
28 \\
20\end{array}$ & $\begin{array}{l}19 \\
31 \\
24\end{array}$ & $\begin{array}{l}25 \\
39 \\
33\end{array}$ \\
\hline $\begin{array}{l}\text { Silver } \\
\text { Background } \\
\text { Old Rifle } \\
\text { New Rifle }\end{array}$ & & $\begin{array}{l}0 / 5 \\
1 / 9 \\
0 / 27\end{array}$ & $\begin{array}{l}<0.01 \\
<0.01 \\
<0.01\end{array}$ & $\begin{array}{l}<0.01 \\
<0.01 \\
<0.01\end{array}$ & $\begin{array}{r}<0.01 \\
0.01 \\
<0.01\end{array}$ \\
\hline
\end{tabular}


Table 3.1 Summary of ground water quality in the alluvial aquifer, Rifle, Colorado, processing sites, August 1990 to August 1994, filtered samples (Continued)

\begin{tabular}{|c|c|c|c|c|c|}
\hline \multirow[b]{2}{*}{ Constituent } & \multirow[b]{2}{*}{ WeH ID } & \multirow[b]{2}{*}{$\begin{array}{l}\text { Frequency } \\
\text { of detection }\end{array}$} & \multicolumn{3}{|c|}{ Observed concentrations } \\
\hline & & & $\begin{array}{l}\text { Minimum } \\
\text { (mg/L) }\end{array}$ & $\begin{array}{l}\text { Median" } \\
\text { (mg/L) }\end{array}$ & $\begin{array}{c}\text { Maximum } \\
\text { (mg/L) }\end{array}$ \\
\hline \multicolumn{6}{|l|}{ Inorganics } \\
\hline \multicolumn{6}{|l|}{ Sodium } \\
\hline $\begin{array}{l}\text { Background } \\
\text { Old Rifle } \\
\text { New Rifle }\end{array}$ & $\begin{array}{l}\text { RFN-01-0583, -0589, } \\
-0590,-0599,-0600 \text {, } \\
-0618\end{array}$ & $\begin{array}{l}15 / 15 \\
9 / 9 \\
22 / 22\end{array}$ & $\begin{array}{r}177 \\
96 \\
1300\end{array}$ & $\begin{array}{r}217 \\
120 \\
2390\end{array}$ & $\begin{array}{r}610 \\
324 \\
3850\end{array}$ \\
\hline $\begin{array}{l}\text { Strontium } \\
\text { Background } \\
\text { Old Rifle }^{d} \\
\text { New Rifled }\end{array}$ & $\begin{array}{l}\text { RFO-01-0584 } \\
\text { RFN-01-0599, -0618 }\end{array}$ & $\begin{array}{l}5 / 5 \\
4 / 4 \\
5 / 5\end{array}$ & $\begin{array}{l}1.5 \\
3.5 \\
3.6\end{array}$ & $\begin{array}{l}1.8 \\
3.7 \\
4.0\end{array}$ & $\begin{array}{l}1.9 \\
3.8 \\
5.2\end{array}$ \\
\hline $\begin{array}{l}\text { Sulfate } \\
\text { Background } \\
\text { Old Rifle } \\
\text { New Rifle }\end{array}$ & $\begin{array}{l}\text { RFO-01-0584 } \\
\text { RFN-01-0583, -0589, } \\
-0590,-0599,-0600 \text {, } \\
-0618\end{array}$ & $\begin{array}{l}15 / 15 \\
4 / 4 \\
21 / 21\end{array}$ & $\begin{array}{r}476 \\
1050 \\
1560\end{array}$ & $\begin{array}{r}857 \\
1066 \\
7350\end{array}$ & $\begin{array}{r}1240 \\
1530 \\
12600\end{array}$ \\
\hline $\begin{array}{l}\text { Thallium } \\
\text { Background } \\
\text { Old Rifle } \\
\text { New Rifle }\end{array}$ & & $\begin{array}{l}0 / 2 \\
0 / 2 \\
1 / 5\end{array}$ & $\begin{array}{l}<0.01 \\
<0.01 \\
<0.01\end{array}$ & $\begin{array}{l}<0.01 \\
<0.01 \\
<0.01\end{array}$ & $\begin{array}{r}<0.01 \\
<0.01 \\
0.01\end{array}$ \\
\hline $\begin{array}{l}\text { Tin } \\
\text { Background } \\
\text { Old Rifle } \\
\text { New Rifle }\end{array}$ & & $\begin{array}{l}0 / 2 \\
0 / 6 \\
0 / 16\end{array}$ & $\begin{array}{l}<0.005 \\
<0.005 \\
<0.005\end{array}$ & $\begin{array}{l}<0.005 \\
<0.005 \\
<0.005\end{array}$ & $\begin{array}{l}<0.005 \\
<0.005 \\
<0.05\end{array}$ \\
\hline $\begin{array}{l}\text { Uranium } \\
\text { Background } \\
\text { Old Rifle }^{d} \\
\text { New Rifle }\end{array}$ & $\begin{array}{l}\text { RFO-01-0583 } \\
\text { RFN-01-0599, }-0618\end{array}$ & $\begin{array}{l}15 / 15 \\
5 / 5 \\
6 / 6\end{array}$ & $\begin{array}{l}0.001 \\
1.6 \\
0.24\end{array}$ & $\begin{array}{l}0.026 \\
1.8 \\
0.29\end{array}$ & $\begin{array}{l}0.046 \\
2.1 \\
0.37\end{array}$ \\
\hline $\begin{array}{l}\text { Vanadium } \\
\text { Background } \\
\text { Old Rifle }^{d} \\
\text { New Rifle }\end{array}$ & $\begin{array}{l}\text { RFO-01-0583 } \\
\text { RFN-01-0590, -0594, } \\
-0600\end{array}$ & $\begin{array}{c}3 / 15 \\
4 / 4 \\
12 / 12\end{array}$ & $\begin{array}{r}<0.01 \\
0.51 \\
0.59\end{array}$ & $\begin{array}{c}<0.01 \\
0.55 \\
1.3\end{array}$ & $\begin{array}{l}0.05 \\
0.75 \\
2.8\end{array}$ \\
\hline \multicolumn{6}{|l|}{ Zinc } \\
\hline $\begin{array}{l}\text { Background } \\
\text { Old Rifle } \\
\text { New Rifle }\end{array}$ & $\begin{array}{l}\text { RFN-01-0590, }-0594, \\
-0600\end{array}$ & $\begin{array}{c}3 / 12 \\
5 / 9 \\
18 / 18\end{array}$ & $\begin{array}{c}<0.005 \\
<0.005 \\
0.30\end{array}$ & $\begin{array}{c}<0.029 \\
<0.005 \\
0.58\end{array}$ & $\begin{array}{l}0.29 \\
0.032 \\
1.6\end{array}$ \\
\hline
\end{tabular}


Table 3.1 Summary of ground water quality in the alluvial aquifer, Rifle, Colorado, processing sites, August 1990 to August 1994, filtered samples (Concluded)

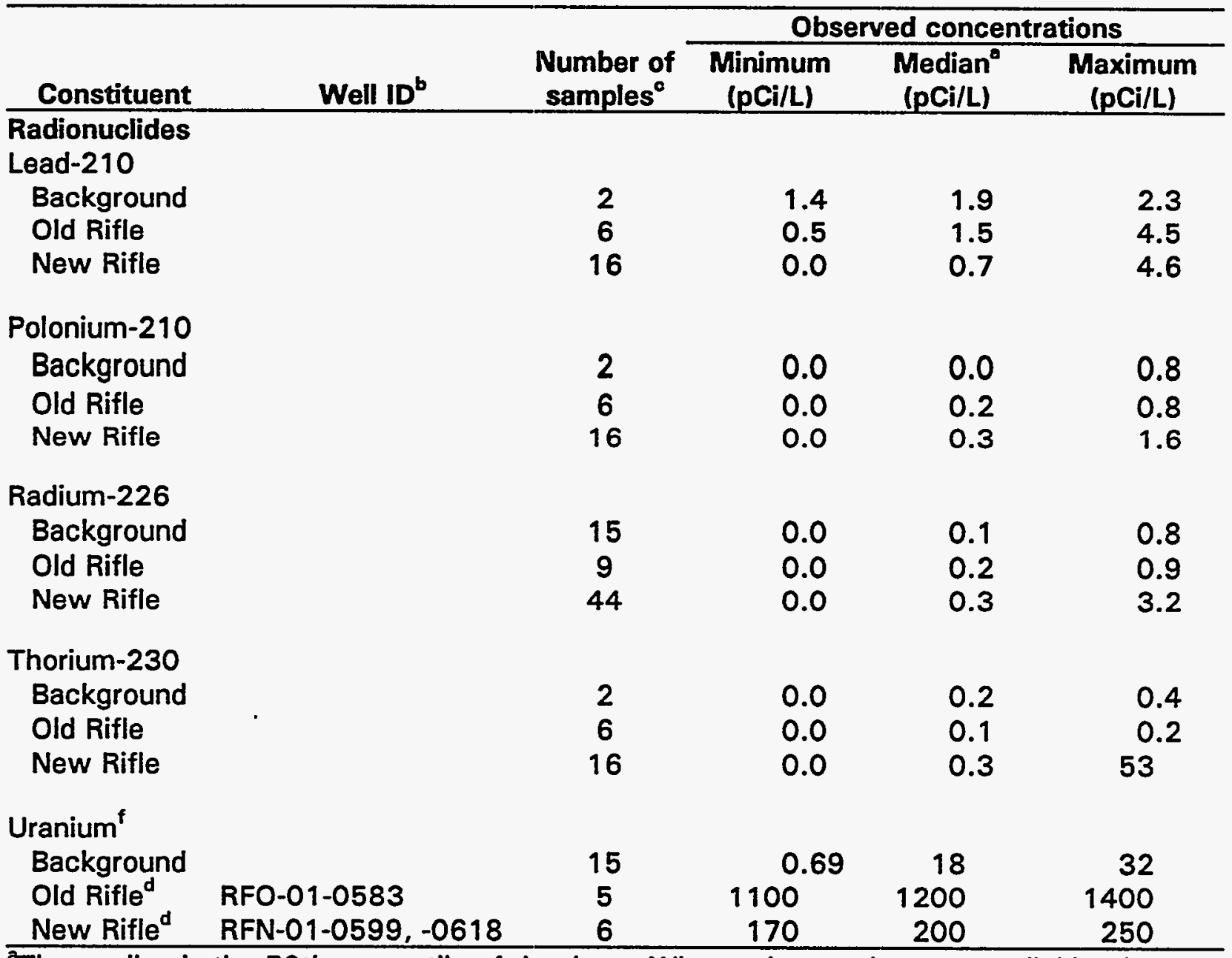

${ }^{2}$ The median is the 50th percentile of the data. When only two data are available, the reported median is the arithmetic mean of the two values.

bBackground wells used are RFO-01-0597, -0598, -0605, -0606. Old Rifle plume wells are RFO-01-0583 and -0584; data are combined unless otherwise indicated. New Rifle plume wells are RFN-01-0581, -0583, -0584, -0587, -0589, -0590, -0594, -0595, -0599, $-0600,-0618$, and -0619 unless otherwise indicated.

'Number of samples with reported concentrations at or above the detection limit/total number of samples.

${ }^{d}$ Constituent is statistically above background. Concentration represents total uranium.

"Data reported as "below detection" as a result of analytical interference were omitted for this summary because the detection limit exceeded the maximum observed concentration in the remainder of the data set.

${ }^{f} \mathrm{mg} / \mathrm{L}$ of uranium was converted into $\mathrm{pCi} / \mathrm{L}$ by multiplying $\mathrm{mg} / \mathrm{L}$ of uranium by 686 . 
Table 3.2 Summary of water quality in the Wasatch Formation, Rifle, Colorado, processing sites, August 1990 to August 1994, filtered samples

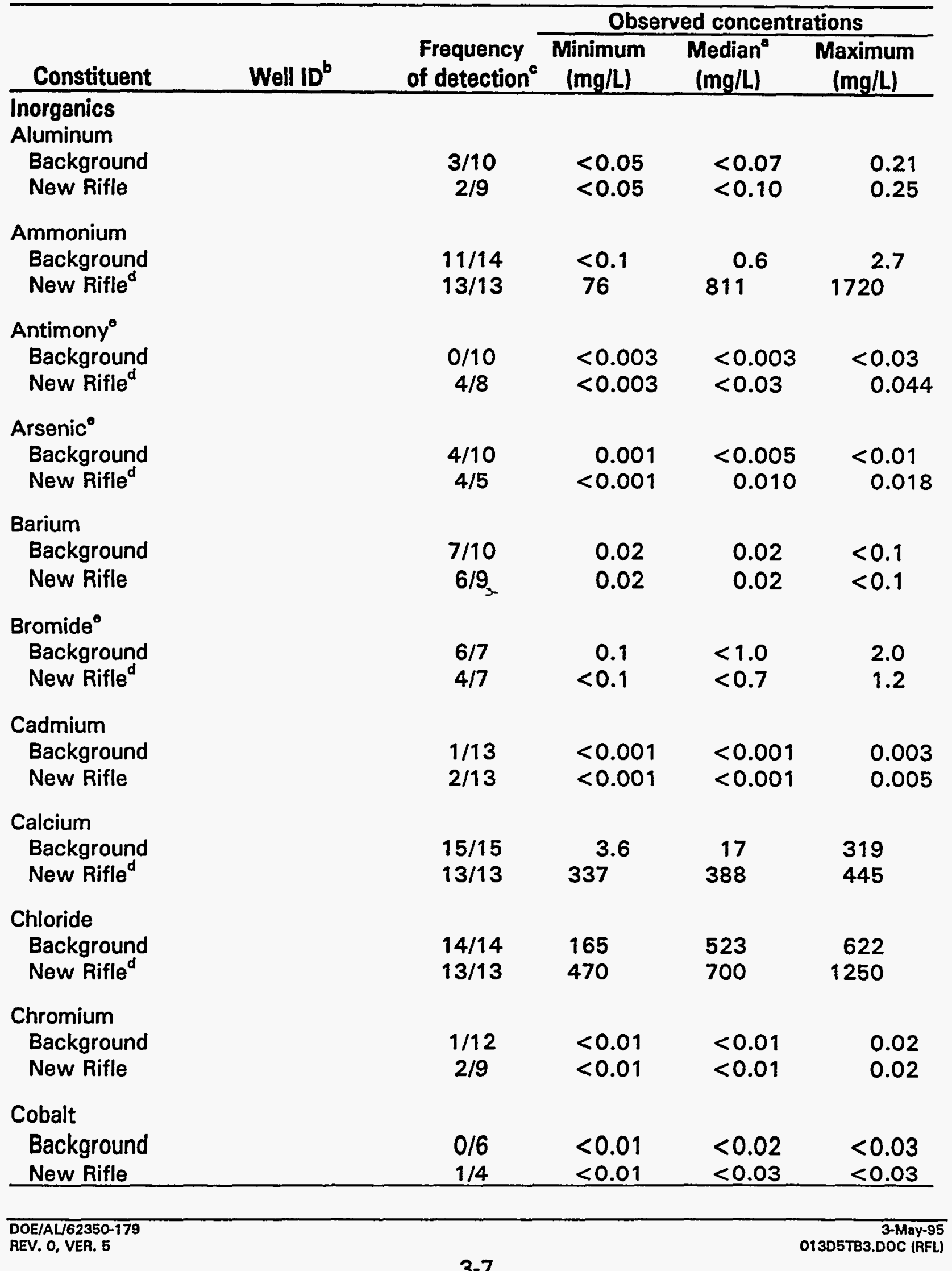


Table 3.2 Summary of water quality in the Wasatch Formation, Rifle, Colorado, processing sites, August 1990 to August 1994, filtered samples (Continued)

\begin{tabular}{|c|c|c|c|c|c|}
\hline \multirow[b]{2}{*}{ Constituent } & \multirow[b]{2}{*}{ Well ID } & \multirow[b]{2}{*}{$\begin{array}{l}\text { Frequency } \\
\text { of detection }\end{array}$} & \multicolumn{3}{|c|}{ Observed concentrations } \\
\hline & & & $\begin{array}{l}\text { Minimum } \\
\text { (mg/L) }\end{array}$ & $\begin{array}{l}\text { Median } \\
\text { (mg/L) }\end{array}$ & $\begin{array}{c}\text { Maximum } \\
\text { (mg/L) }\end{array}$ \\
\hline $\begin{array}{l}\text { Inorganics } \\
\text { Fluoride }\end{array}$ & & & & & \\
\hline $\begin{array}{l}\text { Background } \\
\text { New Rifle }^{d}\end{array}$ & RFN-01-0613 & $\begin{array}{c}14 / 14 \\
2 / 2\end{array}$ & $\begin{array}{l}0.18 \\
6.7\end{array}$ & $\begin{array}{l}2.4 \\
7.1\end{array}$ & $\begin{array}{l}4.5 \\
7.4\end{array}$ \\
\hline Iron & & & & & \\
\hline $\begin{array}{l}\text { Background } \\
\text { New Rifle }\end{array}$ & RFN-01-0613 & $\begin{array}{c}7 / 15 \\
2 / 2\end{array}$ & $\begin{array}{l}<0.02 \\
13\end{array}$ & $\begin{array}{l}<0.03 \\
14\end{array}$ & $\begin{array}{l}0.24 \\
16\end{array}$ \\
\hline $\begin{array}{l}\text { Lead }^{\ominus} \\
\text { Background } \\
\text { New Rifle }\end{array}$ & & $\begin{array}{l}1 / 9 \\
1 / 6\end{array}$ & $\begin{array}{l}<0.001 \\
<0.001\end{array}$ & $\begin{array}{l}<0.005 \\
<0.009\end{array}$ & $\begin{array}{l}<0.01 \\
<0.01\end{array}$ \\
\hline $\begin{array}{l}\text { Magnesium } \\
\text { Background } \\
\text { New Rifle }{ }^{d}\end{array}$ & RFN-01-0611, -0624 & $\begin{array}{l}15 / 15 \\
11 / 11\end{array}$ & $83^{1.1}$ & $\begin{array}{l}4.9 \\
155\end{array}$ & $\begin{array}{l}126 \\
180\end{array}$ \\
\hline $\begin{array}{l}\text { Manganese } \\
\text { Background } \\
\text { New Rifle }^{d}\end{array}$ & RFN-01-0611, -0624 & $\begin{array}{l}12 / 15 \\
11 / 11\end{array}$ & $\begin{array}{c}<0.01 \\
4.7\end{array}$ & $\begin{array}{l}0.06 \\
6.8\end{array}$ & $\begin{array}{l}1.0 \\
8.8\end{array}$ \\
\hline $\begin{array}{l}\text { Molybdenum } \\
\text { Background } \\
\text { New Rifle }\end{array}$ & & $\begin{array}{l}15 / 15 \\
13 / 13\end{array}$ & $\begin{array}{l}0.01 \\
0.24\end{array}$ & $\begin{array}{l}0.20 \\
1.7\end{array}$ & $\begin{array}{l}0.30 \\
3.4\end{array}$ \\
\hline $\begin{array}{l}\text { Nitrate } \\
\text { Background } \\
\text { New Rifle }\end{array}$ & & $\begin{array}{l}7 / 16 \\
5 / 13\end{array}$ & $\begin{array}{l}<0.1 \\
<1.0\end{array}$ & $\begin{array}{l}<1.0 \\
<1.0\end{array}$ & $\begin{array}{r}9.0 \\
10.6\end{array}$ \\
\hline $\begin{array}{l}\text { Nickel } \\
\text { Background } \\
\text { New Rifle }\end{array}$ & & $\begin{array}{l}0 / 3 \\
0 / 2\end{array}$ & $\begin{array}{l}<0.01 \\
<0.01\end{array}$ & $\begin{array}{l}<0.01 \\
<0.01\end{array}$ & $\begin{array}{l}<0.01 \\
<0.01\end{array}$ \\
\hline $\begin{array}{l}\text { Phosphate }^{\text {e }} \\
\text { Background } \\
\text { New Rifle }\end{array}$ & & $\begin{array}{l}4 / 7 \\
4 / 8\end{array}$ & $\begin{array}{l}<0.1 \\
<0.1\end{array}$ & $\begin{array}{r}0.3 \\
<0.3\end{array}$ & $\begin{array}{l}0.6 \\
1.2\end{array}$ \\
\hline $\begin{array}{l}\text { Potassium } \\
\text { Background } \\
\text { New Rifle }\end{array}$ & & $\begin{array}{l}15 / 15 \\
13 / 13\end{array}$ & $5^{1.6}$ & $\begin{array}{l}5.5 \\
75\end{array}$ & $\begin{array}{l}6.7 \\
108\end{array}$ \\
\hline $\begin{array}{l}\text { Selenium } \\
\text { Background } \\
\text { New Rifle } \\
\end{array}$ & & $\begin{array}{l}0 / 15 \\
3 / 13 \\
\end{array}$ & $\begin{array}{l}<0.002 \\
<0.002 \\
\end{array}$ & $\begin{array}{l}<0.005 \\
<0.025 \\
\end{array}$ & $\begin{array}{r}<0.05 \\
0.10 \\
\end{array}$ \\
\hline
\end{tabular}


Table 3.2 Summary of water quality in the Wasatch Formation, Rifle, Colorado, processing sites, August 1990 to August 1994, filtered samples (Continued)

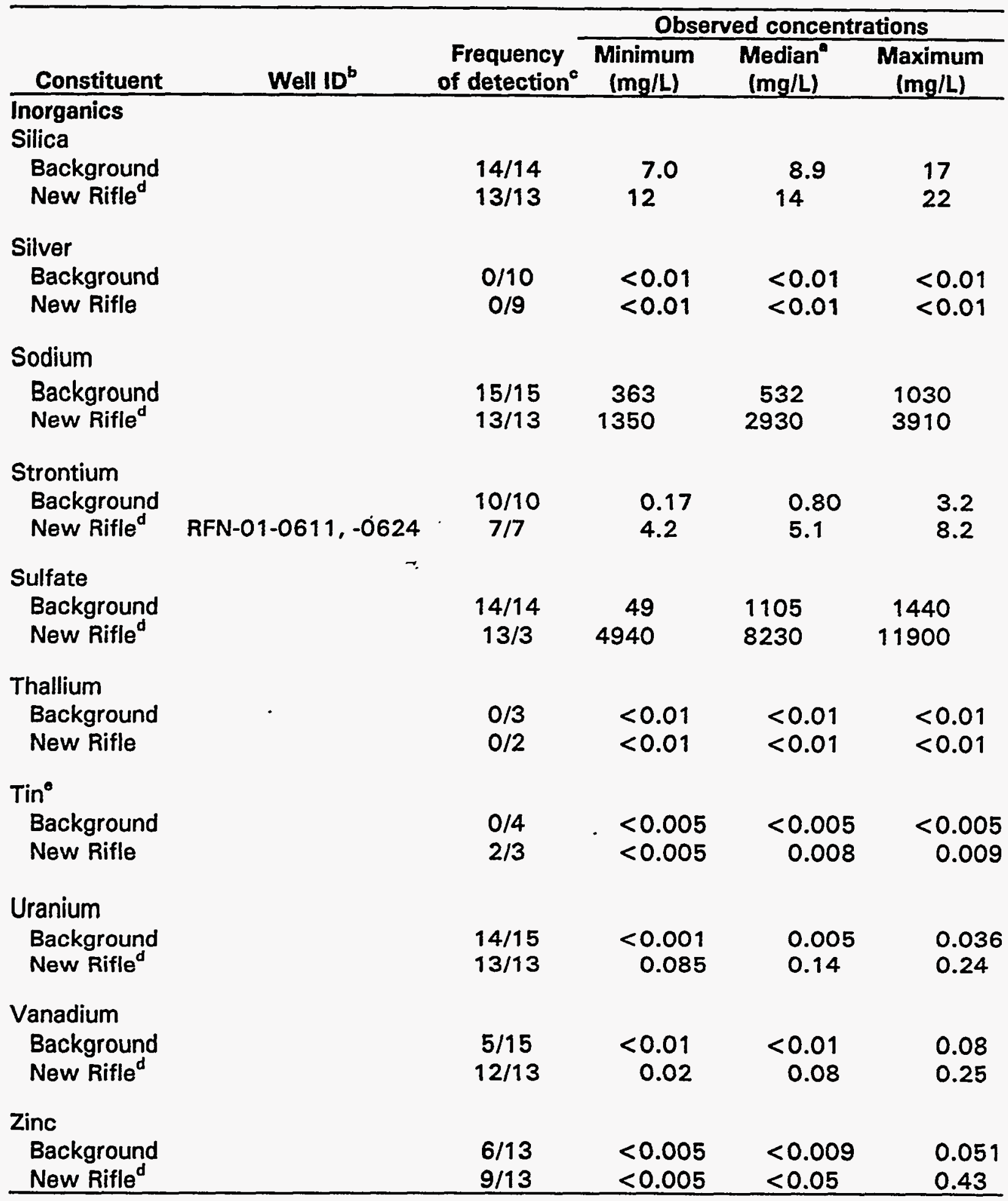


Table 3.2 Summary of water quality in the Wasatch Formation, Fifle, Colorado, processing sites, August 1990 to 1994, filtered samples (Concluded)

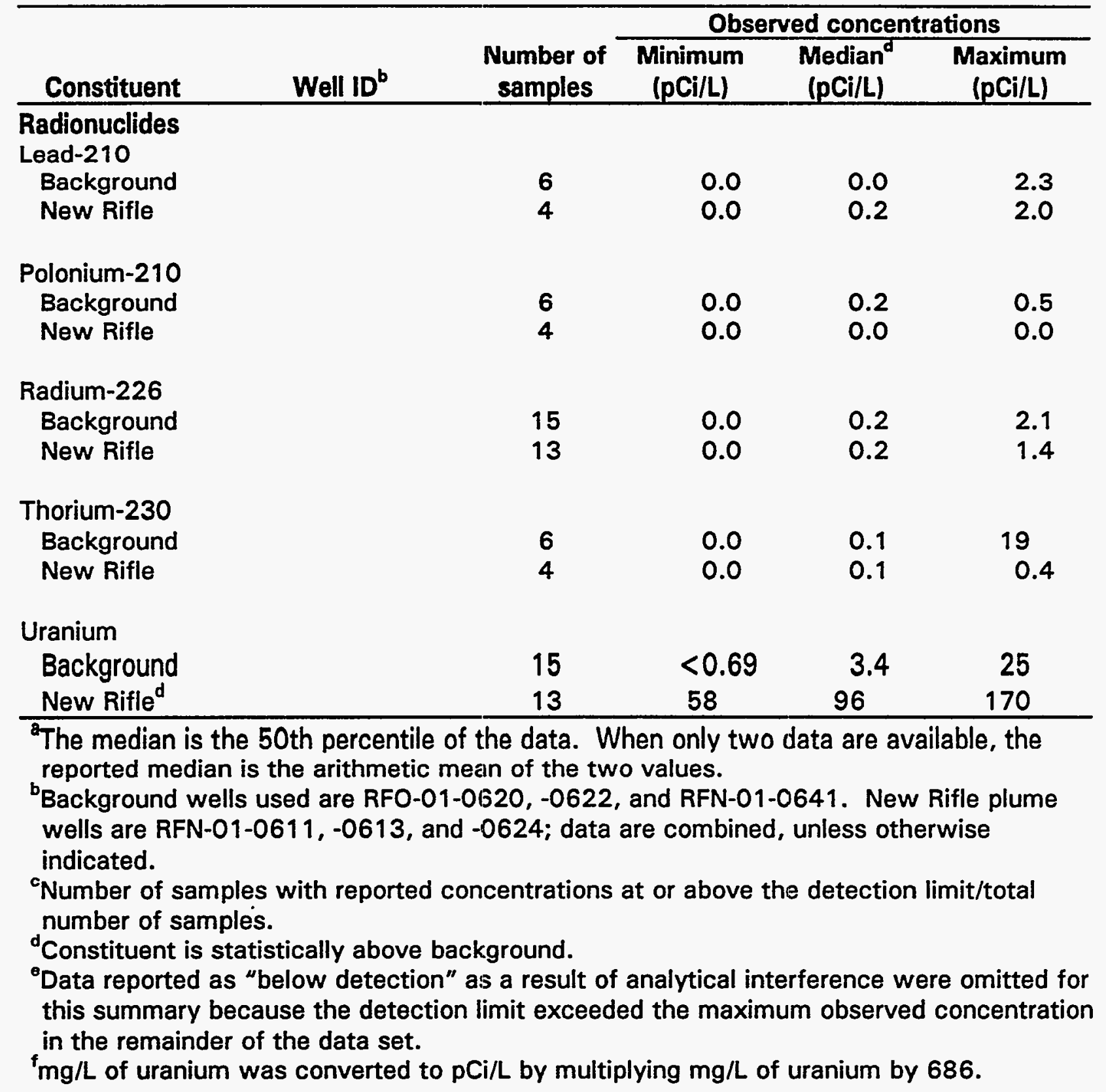


sites are less than $2 \mathrm{mi}(3.2 \mathrm{~km})$ apart and ground water occurs within the same geologic units at both sites. Thus, the same background wells are used to define background ground water quality conditions for both sites. DOE monitor wells selected to describe background ground water quality conditions at the sites contain concentrations of some parameters that exceed UMTRA maximum concentration limits (MCL). Consequently, in addition to a description of local background ground water quality in DOE monitor wells, regional ground water quality data for constituents that occur at relatively high levels in background are discussed here.

\subsubsection{Alluvial background water}

Background water quality data for conditions in the alluvium at both Old and New Rifle are available from Old Rifle upgradient monitor wells RF0-01-0597, $-0598,-0605$, and -0606 (Figure 2.6). These wells are at least $0.5 \mathrm{mi}(0.8 \mathrm{~km}$ ) upgradient of the Old Rifle site and are not affected by Old and New Rifle uranium milling activities. Monitor wells 597 and 598 are downgradient of a gravel pit, and this feature may have affected ground water quality in these wells (DOE, 1992a). Therefore, monitor wells 605 and 606 were installed upgradient of the gravel pit. Two rounds of 1994 sampling data from monitor wells 605 and 606 are consistent with data from monitor wells 597 and 598 , confirming that water quality in wells 597 and 598 represents background water quality in the alluvial aquifer.

Old Rifle monitor wells RFO-01-0600, -0601, -0602, -0603 , and -0604 and New Rifle monitor wells RFN-01-0591/-0592 (Figures 2.6 and 2.7) were all used previously to define background ground water quality in the vicinity of the Old and New Rifle sites (DOE, 1992a; 1992b). These wells are not used to define background conditions in this risk assessment for the following reasons. Monitor wells 591, 592, 600,603, and 604, although upgradient of the New Rifle site, are less than $1.5 \mathrm{mi}(2.4 \mathrm{~km})$ downgradient of the Old Rifle site. A 1985 uranium value reported for ground water in monitor well 591 is $0.15 \mathrm{mg} / \mathrm{L}$. There is little other evidence that these wells were impacted by contamination, but to make a conservative estimate of background, these wells were eliminated. Monitor wells 601 and 602 are across the Colorado River from both sites in an area that does not receive recharge from the same drainage system that recharges ground water at the Rifle UMTRA sites. These wells (601 and 602) were also eliminated from consideration for background.

The pH (a measure of acidity or basicity) of alluvial background ground water ranges from 6.95 to 7.55 and TDSs range from 1690 to $2520 \mathrm{mg} / \mathrm{L}$. Eh conditions (a measure of the tendency for oxidation/reduction reactions to occur) generally are oxidizing, with redox potentials near 400 millivolts (mV). The background alkalinity (as $\mathrm{CaCO}_{3}$ ) ranges from 455 to $530 \mathrm{mg} / \mathrm{L}$. Despite the relatively high alkalinity of these waters, the dominant anionic species in the alluvial background water is sulfate (Figure 3.1). This water has a mixed sodium-calcium-magnesium-cation composition with a tendency for sodium to 


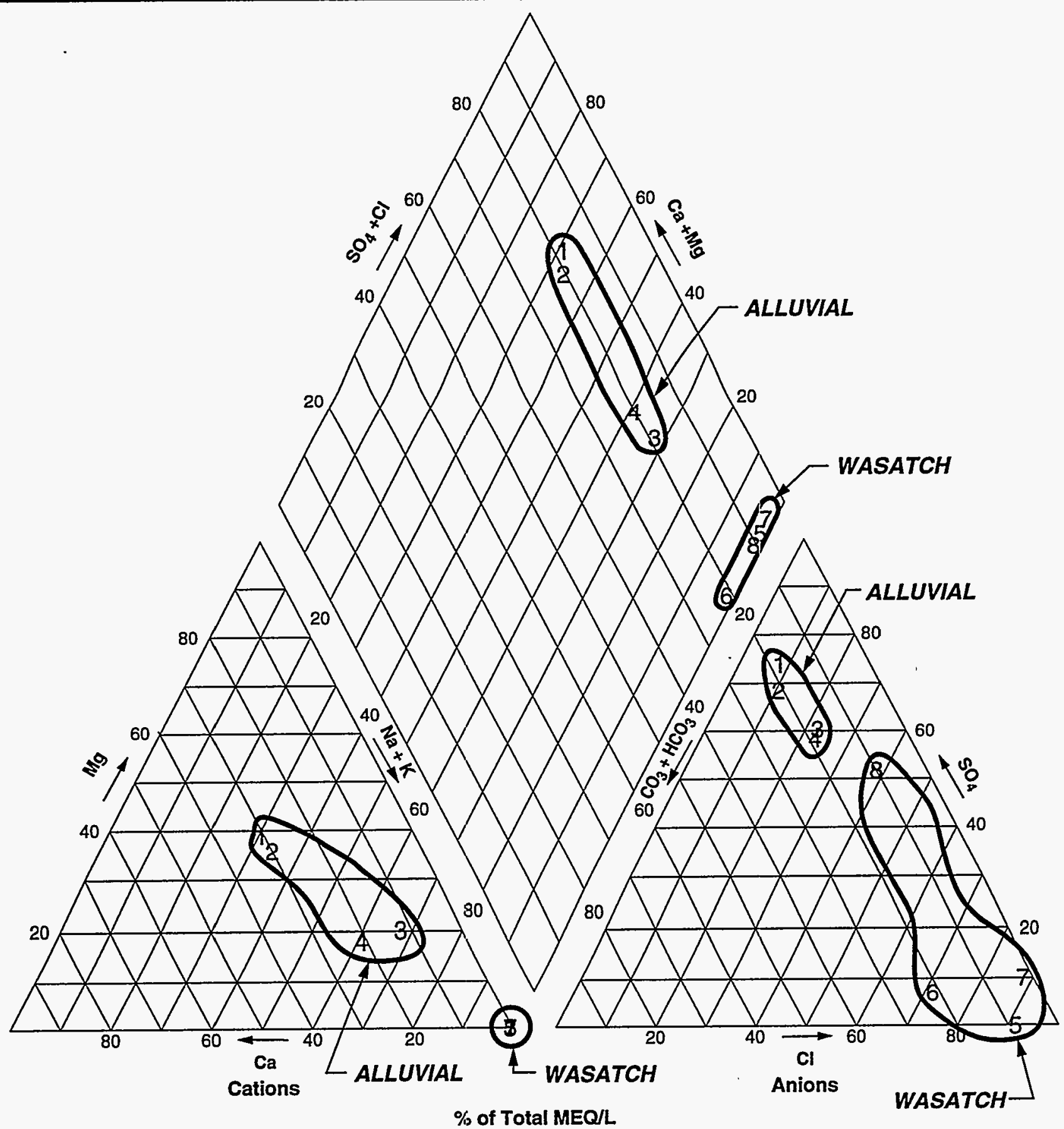

LEGEND

$\begin{array}{cr}\text { NUMBER } & \text { WELL NUMBER } \\ 1 & \text { RFO-01-0597 } \\ 2 & \text { RFO }-01-0598 \\ 3 & \text { RFO-01-0605 } \\ 4 & \text { RFO }-01-0606 \\ 5 & \text { RFO } 01-0621 \\ 7 & \text { RFN }-01-0640 \\ 8 & \text { RFN } 01-0641\end{array}$

OUTLINED FIELDS SHOW THE RANGE OF ALLUVIAL AND WASATCH BACKGROUND WATER.

FIGURE 3.1

TRILINEAR DIAGRAM, MAJOR ELEMENT COIMPOSITION OF ALLUVIAL AND WASATCH FORMATION BACKGROUND GROUND WATER RIFLE, COLORADO, SITE 
dominate. Geochemical modeling of alluvial background monitor wells RFO-01-0597 and -0605, using the computer program PHREEOE (Parkhurst et al., 1980), indicates they are at or near saturation with respect to calcite (calcium carbonate), siderite (ferrous iron carbonate), rhodochrosite (manganese carbonate), and gypsum (calcium sulfate) (TAC, in preparation). Equilibration with these minerals would explain relatively high concentrations of iron, manganese, strontium, sulfate, and alkalinity in this background water.

Most trace elements were detected at low concentrations or were never detected in analyses of background alluvial ground water. However, molybdenum, selenium, and uranium were present in amounts that require further discussion. Historical concentrations (before 1990) of these constituents in alluvial background ground water have been as high as 0.036 (molybdenum), 0.19 (selenium), and 0.046 (uranium) $\mathrm{mg} / \mathrm{L}$. These selenium and uranium values are above UMTRA MCLs. Gross alpha values as high as 56 picocuries per liter ( $\mathrm{pCi} / \mathrm{L}$ ) have been observed in alluvial background water. Phosphate has never been above detection in alluvial background ground water, but nitrate values as high as $7.8 \mathrm{mg} / \mathrm{L}$ have been observed.

\subsubsection{Wasatch background water}

Background water quality data for conditions in the Wasatch Formation at both Old and New Rifle are available from Old Rifle monitor wells RFO-01-620/-0621, and -0622 and New Rifle monitor wells RFN-01-0640 and -0641 (Figures 2.6 and 2.7). Monitor wells 621/622 and 640/641 represent paired Wasatch Formation wells, with one pair upgradient of each site. One well in each pair samples ground water just below the Wasatch/alluvium contact and one well samples ground water from deeper in the Wasatch Formation. Monitor well 620 is near the $621 / 622$ pair but is screened at a shallower depth, sampling water directly below the Wasatch/alluvium contact.

Old Rifle monitor wells RFO-01-625, -0626, and -0641, and New Rifle monitor wells RFN-01-0644 and -0645 (Figures 2.6 and 2.7), used previously to estimate background conditions in the Wasatch Formation (DOE, 1992a), are all across the Colorado River from the Rifle UMTRA sites. All these wells could receive recharge from the drainage system south of the river. The Wasatch Formation near the Rifle UMTRA sites is thought to be influenced primarily by drainage systems north of the river. Therefore, these wells were excluded from the background determination.

The $\mathrm{pH}$ of Wasatch Formation background ground water ranges from 7.8 to 8.6; the $\mathrm{pH}$ tends to be higher in the shallower well of a well pair. Eh conditions are generally oxidizing (redox potentials near $400 \mathrm{mV}$ ). TDSs range from 1200 to $4580 \mathrm{ng} / \mathrm{L}$, with one anomalous value in monitor well 641 of $13,300 \mathrm{mg} / \mathrm{L}$. The higher TDS and pH values tend to occur in the shallower well of the pair. The background alkalinity (as $\mathrm{CaCO}_{3}$ ) ranges from 235 to $469 \mathrm{mg} / \mathrm{L}$. In this case, however, higher values occur in the deeper well of the pair. The dominant anion species in the Wasatch Formation background water is chloride in all wells 
except monitor well 641, which is higher in sulfate (Figure 3.1). Sodium is the dominant cation in all Wasatch Formation background wells. Geochemical modeling of ground water from Wasatch Formation background monitor wells Old Rifle 621 and New Rifle 641, using the computer program PHREEOE (Parkhurst et al., 1980), indicates they are at or near saturation with respect to calcite (calcium carbonate), magnesite (magnesium carbonate), and fluorite (calcium fluoride). Equilibrium with fluorite is consistent with observed concentrations of fluoride as high as $2.6 \mathrm{mg} / \mathrm{L}$ in this background water. In addition, dissolution of carbonate minerals in the aquifer matrix may contribute to strontium values as high as $3.2 \mathrm{mg} / \mathrm{L}$.

Concentrations of molybdenum, selenium, and uranium are noteworthy in Wasatch Formation background water, just as they are in alluvial background water. Historical concentrations of these constituents in Wasatch Formation background ground water have been as high as $0.12 \mathrm{mg} / \mathrm{L}$ for molybdenum, $0.34 \mathrm{mg} / \mathrm{L}$ for selenium, and $0.57 \mathrm{mg} / \mathrm{L}$ for uranium. These values are all above UMTRA MCLs. Other trace elements that were present historically are barium (up to $0.26 \mathrm{mg} / \mathrm{L}$ ), bromide (up to $3.8 \mathrm{mg} / \mathrm{L}$ ), lead (up to $0.015 \mathrm{mg} / \mathrm{L}$ ), vanadium (up to $0.26 \mathrm{mg} / \mathrm{L}$ ), and zinc (up to $0.44 \mathrm{mg} / \mathrm{L}$ ). Among other constituents, gross alpha and gross beta values as high as 121 and $94 \mathrm{pCi} / \mathrm{L}$, respectively, have been observed. Nitrate values as high as $11 \mathrm{mg} / \mathrm{L}$ and phosphate values as high as $6.2 \mathrm{mg} / \mathrm{L}$ have been observed historically.

\subsubsection{Comparison with regional background water}

While there is very little overall information available concerning regional ground water conditions, Markos and Bush (1983) sampled and analyzed ground water in five wells in the Rifle area, all well away from the possible influence of uranium mill-related activities. These data are from an area of about 50 square mile $\left(\mathrm{mi}^{2}\right)$ (129 square kilometer $\left.\left[\mathrm{km}^{2}\right]\right)$ surrounding Rifle. Ground water analyses from this study provide insight into regional ground water quality in the Rifle area, supporting the choice of wells to represent background at the site. Ground water quality in the background wells is similar to regional water quality in several respects. For example, regional sulfate levels range from 68 to near $1000 \mathrm{mg} / \mathrm{L}$ and uranium ranges from 0.002 to $0.067 \mathrm{mg} / \mathrm{L}$. These ranges are similar to background wells (Tables 3.1 and 3.2).

Another indication of regional background is the seep above One Mile Pond (surface location RFO-01-573). While it is technically a surface water sampling location, a seep is ground water that has just emerged at the surface. This seep issues from colluvium overlying the escarpment of Wasatch Formation that rises nearly $100 \mathrm{ft}(31 \mathrm{~m})$ above the top of the Old Rifle tailings pile approximately $1 \mathrm{mi}(1.6 \mathrm{~km})$ northeast of the Old Rifle site. Thus, water at this location could not be impacted liy uranium milling activities. Water quality analyses from this location show total uranium concentrations up to $0.048 \mathrm{mg} / \mathrm{L}$, gross alpha up to $33 \mathrm{pCi} / \mathrm{L}$, and total sulfate concentrations up to $2010 \mathrm{mg} / \mathrm{L}$. 
The above discussion indicates that, in spite of the paucity of regional information, several constituents associated with uranium ores are present at elevated levels in regional ground water. This likely is because the regional ground water recharge area contains the uranium ore bodies described in Section 2.0. Other, unknown uranium ore bodies may be present. A study by Markos and Bush (1983) did not demonstrate that molybdenum and selenium are present at high levels in regional background as they are in site background monitor wells. This difference most likely is due to the small number of sampling locations. Molybdenum and selenium are commonly associated with uranium deposits (Evans, 1987) and their presence in association with uranium in background monitor wells is expected.

\subsection{MAGNITUDE OF SITE-RELATED CONTAMINATION}

Merritt (1971) indicates that salt roasting and acid leaching of roscoelite-type uranium/vanadium ores contributed sodium chloride $(\mathrm{NaCl})$ and sulfuric acid $\left(\mathrm{H}_{2} \mathrm{SO}_{4}\right)$ to the tailings piles, and, thus, to the ground water at both the Old and New Rifle sites. Vanadate oxidation and neutralization also added sodium chlorate $\left(\mathrm{NaClO}_{3}\right)$, sodium hydroxide $(\mathrm{NaOH})$, and sodium carbonate $\left(\mathrm{Na}_{2} \mathrm{CO}_{3}\right)$. Additionally, at Old Rifle ammonia gas $\left(\mathrm{NH}_{3}\right)$ was used as a neutralizer and iron sulfate $\left(\mathrm{Fe}_{2}\left(\mathrm{SO}_{4}\right)_{3}\right)$ was used to precipitate iron vanadate. At New Rifle, a solvent extraction used di(2-ethylhexyl) phosphoric acid (EHPA), most likely in a carrier such as kerosene. - Also at $\mathrm{New}$ Rifle, ammonium chloride $\left(\mathrm{NH}_{4} \mathrm{Cl}\right)$ was used in a purifying step. Thus, major indicators of contamination expected in downgradient wells at both sites are the sodium $\left(\mathrm{Na}^{+}\right)$, ammonium $\left(\mathrm{NH}_{4}{ }^{+}\right)$, sulfate $\left(\mathrm{SO}_{4}{ }^{2-}\right)$, and chloride $(\mathrm{Cl})$ ions. Secondary indicators of contamination are nitrate $\left(\mathrm{NO}_{3}{ }^{\circ}\right)$ (from oxidation of ammonium) and phosphate $\left(\mathrm{PO}_{4}{ }^{3}\right.$ ) (from phosphoric acid). Contaminants that can be expected in association with the uranium/vanadium ores themselves are arsenic, molybdenum, selenium, uranium, and vanadium (Evans, 1987).

Ground water quality data collected from downgradient wells at both sites from 1981 through 1994 show strongly decreasing concentrations of most constituents associated with uranium processing (TAC, in preparation). These trends are particularly noticeable at New Rifle where, for example, sulfate concentrations in monitor well RFN-01-0593 have declined from $40,400 \mathrm{mg} / \mathrm{L}$ in 1985 to $2760 \mathrm{mg} / \mathrm{L}$ in 1992 (the most recent result from this well). Major sources of contamination at the Old and New Rifle sites were the tailings piles at each site and the vanadium ponds at the New Rifle site. These contaminant sources are being removed as part of surface remedial action.

There is little direct information concerning the chemical composition of the tailings pore fluids or the liquid in the vanadium ponds. Only two of five Iysimeters installed in the Old Rifle tailings pile produced enough liquid for analysis. The lysimeters were sampled in December 1988 and April 1989. Lysimeters installed in the New Rifle tailings did not yield enough liquid for analysis (TAC, in preparation). 
Markos and Bush (1983) took core samples of tailings materials at both Old and New Rifle. These materials were water-leached to determine the water soluble constituents in the tailings solids. These are the constituents that could be added to the ground water system as precipitation or irrigation water leaches through the tailings piles. The maximum values of major contamination indicators observed in leach tests of Old and New Rifle tailings solids and maximum values observed in Old Rifle tailings lysimeters were compared with maximum historical values observed in alluvial background and in alluvium on the site or downgradient of tailings piles at both sites.

Water leach data and lysimeter data from Old Rifle are roughly concordant and these values are generally of the same order of magnitude as downgradient values observed at Old Rifle. Thus, the high values observed in Old Rifle downgradient wells from 1983 to 1985 are probably the result of water leaching through the tailings pile. Values for most of the more mobile constituents in downgradient wells at Old Rifle have declined. The tailings pile at Old Rifle is being removed and high values probably will not be repeated in the future.

Water leach data from New Fifle are in agreement with Old Rifle water leach and lysimeter data. However, maximum values from downgradient wells are significantly higher than water leach data for several parameters. Thus, early high values at New Rifle are not simply the result of water leaching through the tailings pile, but probably reflect the direct contribution of processing fluids.

Differences between the two sites may be related to differences in the extent of alluvium at each site (see Section 2.4.2) and to higher average ground water velocities at Old Rifle having dispersed processing fluids more quickly than at New Rifle. Also, the presence of processing fluids at New Rifle may reflect more recent processing activities at the site. Vanadium processing continued at the New Rifle site until 1984 (DOE, 1990)

In paired deep and shallow downgradient alluvial wells at both sites, concentrations of constituents associated with uranium processing consistently arrive in deeper wells first. For example, New Rifle alluvial monitor wells RFN-01-0598 and -0599 are less than $10 \mathrm{ft}(3 \mathrm{~m})$ from each other (Figure 2.7). Monitor well 598 is screened from 6 to $11 \mathrm{ft}(2$ to $3.4 \mathrm{~m})$ below the surface and monitor well 599 is screened from 12 to $17 \mathrm{ft}(3.7$ to $5.2 \mathrm{~m})$ below the surface. The early high value in monitor well 599 for sulfate is $14,000 \mathrm{mg} / \mathrm{L}$ (June 1985). The sulfate value in monitor well 598 on the same date is $8800 \mathrm{mg} / \mathrm{L}$.

Conversely, in paired deep and shallow downgradient Wasatch Formation wells at both sites, constituents arrive in the shallower well first. For example, New Rifle Wasatch Formation moritor wells RFN-01-0650 and -0651 are less than $40 \mathrm{ft}(12 \mathrm{~m})$ apart (Figure 2.7). Monitor well 650 is screened from 84 to $94 \mathrm{ft}$ $(26$ to $29 \mathrm{~m})$ below the surface and monitor well 651 is screened from 55 to $65 \mathrm{ft}(17$ to $20 \mathrm{~m})$ below the surface. June 1985 sulfate concentrations in wells 650 and 651 are 454 and $811 \mathrm{mg} / \mathrm{L}$, respectively. 
These observations suggest that most tailings-related contamination at both sites moves along the interface between the overlying alluvium and the upper weathered Wasatch Formation. This, in turn suggests this interface forms a more permeable pathway than either unit alone. Thus, variations in permeability along the interface could lead to complex contaminant distributions.

To estimate the current extent of contamination, Figures 3.2, 3.3, and 3.4 show the current uranium distribution in the alluvium at the Old Rifle site and in the alluvium and the Wasatch Formation at the New Rifle site. There are not enough well locations in the Wasatch Formation at the Old Rifle site to fully characterize the contamination distribution. However, contamination at both sites is less extensive in the Wasatch Formation than in the alluvium. Because contamination moves more readily along the Wasatch/alluvium interface, and because the alluvium and the weathered Wasatch Formation are hydraulically connected, it is possible the Wasatch could be contaminated at locations as far downgradient as those in the alluvium. However, most contamination in the Wasatch Formation does not appear to have moved far from the tailings pile (Figures 3.3 and 3.4). This is consistent with the lower permeability of the Wasatch Formation described in Section 2.5.

At Old Rifle, the alluvium is bounded on the north by an escarpment of the Wasatch Formation and on the south by the Colorado River (Figure 3.2) with ground water flowing southwest in the alluvium, parallel to the river when the river is high. The Wasatch Formation escarpment extending toward the river funnels the bulk of alluvial ground water flow into the Colorado River. Thus, most contamination is confined to the processing and tailings site itself. However, relatively low levels of site-related constituents are reported downgradient of the promontory to alluvial monitor well RFN-01-0590 and possibly -0600 . The uranium value in monitor well 590 from the March 1994 sampling round was $0.11 \mathrm{mg} / \mathrm{L}$. Uranium values are not above background in monitor well 600 but iron values have been near $10 \mathrm{mg} / \mathrm{L}$ since 1991 .

At New Rifle, as at Old Rifle, the alluvium pinches out against an escarpment of Wasatch Formation directly north of the site. The Wasatch Formation escarpment north of the New Rifle site is approximated by the $5280 \mathrm{ft}(1610 \mathrm{~m})$ elevation contour on Figure 3.3. Therefore, ground water flow in the alluvium is effectively limited to the area between the Wasatch Formation escarpment north of the site and the Colorado River south of the site with ground water flowing west, parallel to the river. Thus, contamination is elongated west of the site, in the general direction of ground water flow (Figure 3.3).

At New Rifle, elevated levels of certain constituents in far downgradient monitor well RFN-01-0620 (Figure 2.6) indicate that uranium processing-related contamination may have traveled as much as $3 \mathrm{mi}(4.8 \mathrm{~km})$ in the direction of ground water flow. Concentrations of calcium, chloride, magnesium, nitrate, sodium, and sulfate show increasing trends over time in monitor well 620. Sodium and sulfate, however, are the primary constituents that are elevated above background with levels up to 1300 and $2900 \mathrm{mg} / \mathrm{L}$, respectively. 


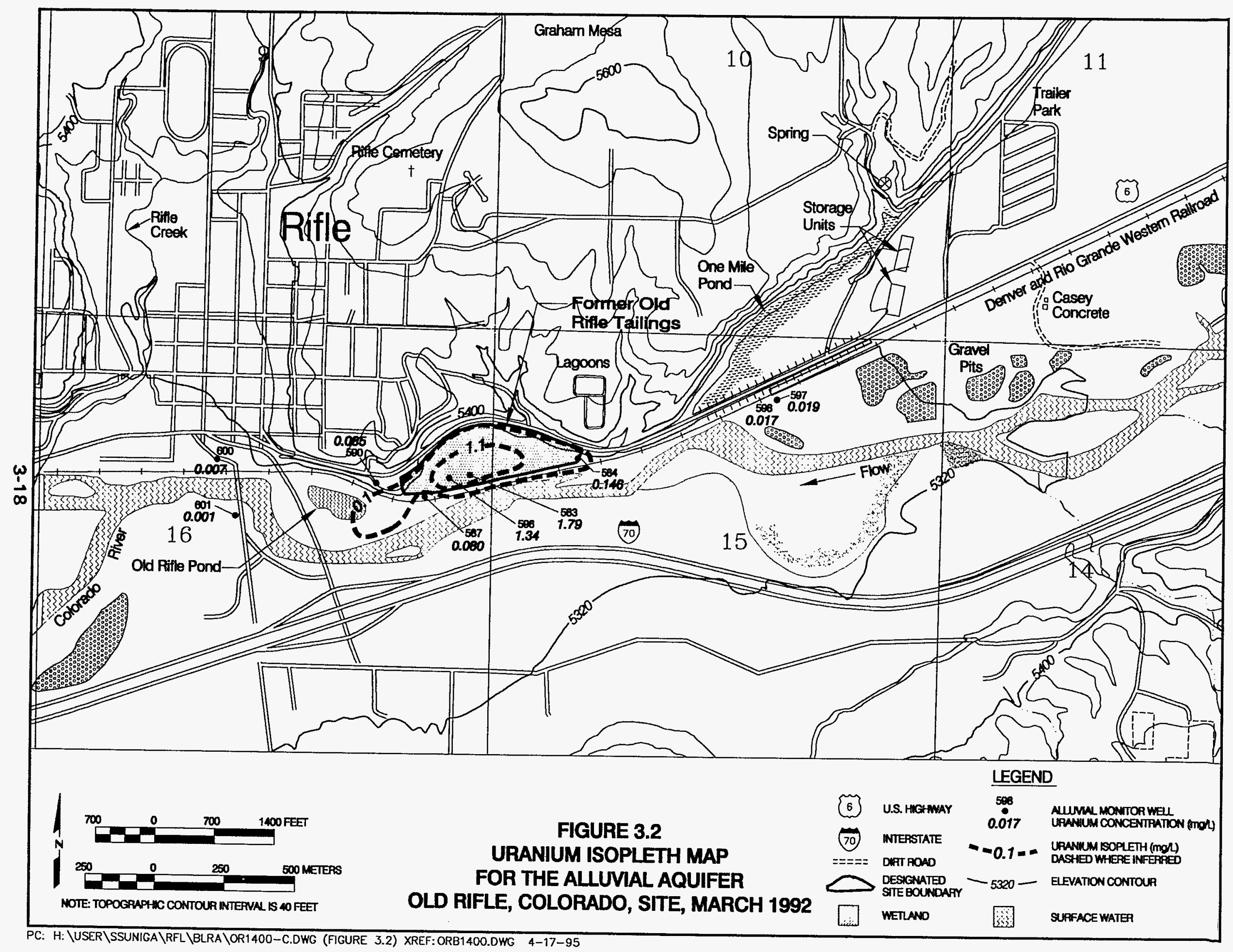




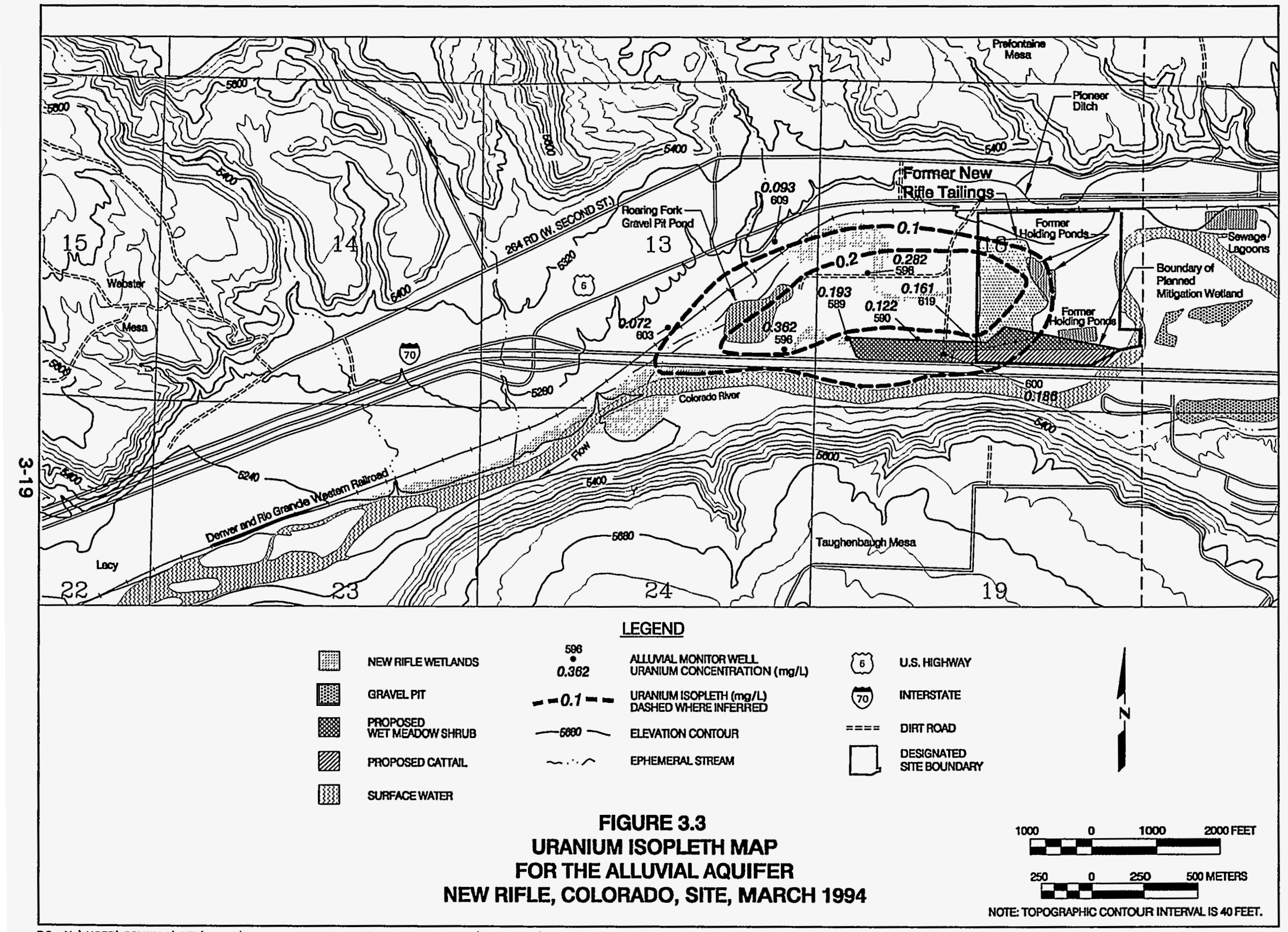

PC: H: \USER\SSUNIGA \RFL \BLRA \UIAMAR94.DWG XREF-BASE2000.DWG (FIGURE3.3) 4-20-95 
Uranium, another primary indicator of contamination from uranium milling activities, is only slightly elevated above background at the Rifle sites. Similar levels occur in a natural seep (Old Rifle surface location RFO-01-0573) demonstrating that a natural source is possible for ground water in wells RFN-01-0620 and -0428 .

There are other possible explanations for observed constituent levels in these wells. Monitor well 620 and nearby private well 428 have similar constituent levels and probably receive ground water from a recharge area to the west that includes large exposures of the Green River Formation. The Green River Formation is notable for the occurrence of a variety of unusual sodium salts (Greensmith et al., 1971). Thus, high sodium and sulfate levels could be coming from this alternate source. Also, well 620 is in an irrigated field with white salts crusted on the surface. These salts likely are sodium sulfate salts from evaporating sodium sulfate water (the dominant ground water type in the alluvial aquifer). A light rain would dissolve these salts, elevating sodium and sulfate in nearby ground water. Nitrate is commonly used to fertilize crops. Thus, observed levels of these constituents could reasonably have come from sources other than uranium milling related activities. Additionally, weils RFN-010620 and -0428 are more than $1 \mathrm{mi}(1.6 \mathrm{~km})$ further downgradient than the furthest extent of contamination predicted with estimated average ground water velocities at the site (DOE, 1992a). Because of these uncertainties, there are not enough data to state conclusively that elevated constituent levels observed in monitor well 620 (and in private well 428) are related to uranium processing.

Other than well 428 , private wells monitored in the vicinity of the Old and New Rifle sites are either upgradient or so far crossgradient that the chance of impact by site-related activities is small to nonexistant (Section 2.0). Geochemical evaluation of these wells verifies that they are not impacted. Mean nitrate values up to $8.7 \mathrm{mg} / \mathrm{L}$ in two wells can be attributed to leaking septic tanks or garden fertilizer and mean sulfate values of $1485 \mathrm{mg} / \mathrm{L}$ in one well may be from local clay and gypsum in the Wasatch Formation where the well is completed. No other parameters exceed mean background.

\subsection{SURFACE WATER AND SEDIMENT}

Surface water sampling locations are shown in Figure 2.12. Surface water sites in the Rifle area have been sampled periodically since 1986, but the analyte list has varied and sampling locations have not been consistent (TAC, in preparation). For these reasons, and in an effort to represent current conditions at the site, only data from the most recent sampling round (March 1994) are used in this assessment, with two exceptions. The most recent sampling event at the New Rifle wetland (surface location RFN-01-0576) was in February 1992; these data will be compared with other locations. In addition, the wetland location was sampled in October 1991 with very different results. To show the strong seasonal variability of water quality at this location, Table 3.3 presents 
data from both sampling dates and the March 1994 data for all other surface locations. The baseline risk assessment supplement contains results of the surface water analyses (TAC, in preparation).

Water quality from the Old Rifle upstream background location on the Colorado River (RFN-01-0538) and New Rifle downgradient locations (RFN-01-0545 and -0548 ) is dominated by sodium and chloride, with TDS concentrations near $600 \mathrm{mg} / \mathrm{L}$. Excluding measurement and sampling variability, there are no differences in trace element concentrations (including arsenic, cadmium, molybdenum, selenium, uranium, vanadium, and zinc) in surface water samples taken upstream and downstream of the Rifle sites. The same is true of trace element concentrations in sediment samples taken at the same locations (Table 7.2). Therefore, any contaminated ground water is greatly diluted as it enters the Colorado River.

In the semiarid climate of western Colorado, water tends to evaporate from standing water bodies. For example, One Mile Pond (Old Rifle surface location RFO-01-0570) is a background location that contained $761 \mathrm{mg} / \mathrm{L}$ TDSs in March 1994 (a relatively wet time of year) and $3060 \mathrm{mg} / \mathrm{L}$ in August 1994 (a dry time of year). Thus, evaporation has increased the concentrations of dissolved salts in water at this location fourfold in less than 5 months. Water at this location contains roughly equal amounts of the major cations (calcium, magnesium, and sodium) and a 60-to-40 mix of sulfate and bicarbonate anions.

Water quality in Old Rifle pond (Old Rifle surface location RF0-01-0572) is similar to water quality in One Mile Pond except that lower TDS values and higher chloride concentrations are evidence of greater river influence in Old Rifle pond. With the exception of uranium, trace element concentrations in water show negligible differences between the two locations (Table 3.3). The uranium value of $0.017 \mathrm{mg} / \mathrm{L}$ is lower than the $0.026 \mathrm{mg} / \mathrm{L}$ median value reported for the alluvial aquifer (one source of water in Old Rifle pond). However, certain trace elements are considerably elevated above background in sediment samples. Cadmium, uranium, and zinc are notably high. These elements likely are adsorbed onto iron oxides and hydroxides in ground water that precipitates out of solution as ferrous iron enters strongly oxidizing surface water.

The Roaring Fork gravel pit pond and the wetlands at New Rifle (New Rifle surface locations RFN-01-0575 and -0576) both show strong evaporation effects. Tailings-related contamination clearly has affected these waters. Water quality is dominated by sodium and sulfate, two major indicators of contamination. Ammonium and nitrate are also high (Table 3.3). Uranium is as high as $0.31 \mathrm{mg} / \mathrm{L}$ and molybdenum is as high as $0.67 \mathrm{mg} / \mathrm{L}$. These values are from winter sampling rounds, which represent the wet time of year. Concentrations could be much higher in a dry time of year. For example, surface location 576 had a TDS concentration of 2810 in February 1992, but in October 1991 it was near $28,000 \mathrm{mg} / \mathrm{L}$ lestimated from concentrations of major ions). In sediment sample data, certain trace elements are elevated above values in One Mile Pond (background). For example, at a small wetland 
southwest of the Roaring Fork gravel pit pond (location RFN-01-0538) the uranium concentration in the sediment is 8.9 parts per million (ppm) and the molybdenum concentration is $19 \mathrm{ppm}$ (see Section 7.3.2) (TAC, in preparation).

In summary, Rifle site-related ground water contamination has the potential to enter two different types of surface water environments. The Colorado River represents first type and the second type consists of ponds and wetlands in the alluvium downgradient of the Rifle sites. Ground water contamination that enters the Colorado River quickly dilutes to background levels. In contrast, ponds and wetlands are strorigly affected by evapotranspiration, and ground water contamination that enters these features could build up over time in both surface water and sediment.

Water quality data presented in Sections 3.1 and 3.2 were used to compile a list of contaminants of potential concern for the Old and New Rifle alluvial aquifers. A list was also prepared for the weathered portion of the Wasatch Formation under the New Rifle site. Potential contamination of the Wasatch underlying the Old Rifle site could not be evaluated due to insufficient well coverage in the area. The human health evaluation in Section 6.0 is based on an assessment of the levels of these contaminants of potential concern and their corresponding toxicities.

Selecting contaminants of potential concern for human health is a two-step process. First, statistical methods are used to identify constituents with higher concentrations on the site or downgradient from the site than in background waters. These constituents then undergo toxicity screening that focuses on contaminants with the greatest potential to affect human health.

\subsubsection{Statistical analyses of ground water quality}

Statistical comparisons of on-site and background ground water quality were conducted to determine the constituents at each site that are elevated above background. The on-site wells used in the comparisons represent the greatest levels of contamination associated with the heart of the contaminant plume. A complete description of the statistical methods used in this assessment is presented in a statistician's report (TAC, in preparation). Statistical testing was conducted at the 0.10 level of significance.

\section{Alluvial ground water at the Old Rifle site}

Water quality data from Old Fifle monitor wells RF0-01-0597, -0598, -0605, and -0606 were used to describe backiground water quality for the alluvial aquifer at the Old Rifle site. Monitor wells 597 and 598 are approximately $10 \mathrm{ft}$ $(3 \mathrm{~m})$ from each other and the water quality of the two wells is very similar; therefore, when the variation in background water quality was quantified, these two wells were viewed as representing a single location. Since 1990, monitor 
well 597 has been sampled seven times and 598 five times. DOE monitor wells 605 and 606 were installed in 1994. Two sampling rounds of 1994 data are available for Old Rifle monitor well 605 and one round for 606 .

Water quality data from on-site wells RFO-01-0583 and -0584 at Old Rifle generally were used in the statistical comparisons with background. However, data from additional on-site and downgradient wells were included in assessments of constituents with low detectability. Table 3.1 summarizes background and on-site water quality in the alluvial aquifer at the Old Rifle site and identifies wells used in this assessment. In Table 3.1, background data are pooled and on-site concentrations reflect the wells with the highest average concentration of the constituent.

Cadmium, cobalt, lead, nickel, silver, thallium, and tin were eliminated from consideration at Old Rifle because detectable levels were not measured or because the frequency of detection was extremely low in the on-site and downgradient monitor wells.

The following monitored constituents showed high percentages of nondetects in the background and/or on-site well data, and were statistically evaluated using the nonparametric Wilcoxon rank-sum test: aluminum, antimony, arsenic, barium, bromide, chromium, phosphate, selenium, vanadium, and zinc.

The remaining monitored constituents are present in detectable concentrations in both background and on-site wells: ammonium, calcium, chloride, fluoride, iron, magnesium, manganese, molybdenum, nitrate, potassium, silica, sodium, strontium, sulfate, and uranium. For these constituents, analysis of variance (ANOVA) was used to determine if the mean concentration in Old Rifle wells RFO-01-0583 or -0584 exceeded the mean of the three locations representing background (597/598, 605, and 606). When necessary, a mathematical transformation such as the logarithmic transformation was applied to the data to equalize variances prior to applying the ANOVA procedure.

These statistical analyses identified 15 constituents that are higher on the site than in background in the alluvial aquifer at the Old Rifle site (Table 3.4).

\section{Alluvial water quality at the New Rifle site}

Background alluvial water quality is expected to be similar at the Old and New Rifle sites, and the same background well data were used in the statistical assessments of both sites. The following on-site or downgradient wells were used in one or more of the statistical comparison procedures for the New Rifle alluvium: RFN-01-0581, -0583, -0584, -0587, -0589, -0590, -0594, -0595, $-0599,-0600,-0618$, and -0619 . Table 3.1 compares background ground water quality to concentrations in the most contaminated wells on or downgradient from the New Rifle site. Table 3.1 also compares concentration levels at the two sites. 
Table 3.4 Contaminants of potential concern for human health evaluation for the alluvial aquifer at the Old Rifle, Colorado, site

\begin{tabular}{|c|c|c|c|}
\hline $\begin{array}{c}\text { Contaminants } \\
\text { that exceed } \\
\text { background levels }\end{array}$ & $\begin{array}{l}\text { Contaminants in } \\
\text { nutritional range }\end{array}$ & $\begin{array}{c}\text { Contaminants of low } \\
\text { toxicity and/or high } \\
\text { dietary range }\end{array}$ & $\begin{array}{l}\text { Contaminants of } \\
\text { potential concern }\end{array}$ \\
\hline $\begin{array}{l}\text { Ammonium } \\
\text { Arsenic } \\
\text { Calcium } \\
\text { Fluoride } \\
\text { Iron } \\
\text { Magnesium } \\
\text { Manganese } \\
\text { Molybdenum } \\
\text { Phosphate } \\
\text { Selenium } \\
\text { Silica } \\
\text { Strontium } \\
\text { Sulfate } \\
\text { Uranium } \\
\text { Vanadium }\end{array}$ & $\begin{array}{l}\text { Calcium } \\
\text { Phosphate }\end{array}$ & $\begin{array}{l}\text { Ammonium } \\
\text { Magnesium } \\
\text { Silica } \\
\text { Strontium }\end{array}$ & $\begin{array}{l}\text { Arsenic } \\
\text { Fluoride } \\
\text { Iron } \\
\text { Manganese } \\
\text { Molybdenum } \\
\text { Selenium } \\
\text { Sulfate } \\
\text { Uranium } \\
\text { Vanadium } \\
\text { Lead-210 } \\
\text { Polonium-210 } \\
\text { Radium-226 } \\
\text { Thorium-230 }\end{array}$ \\
\hline
\end{tabular}

${ }^{a}$ All radionuclides detected were retained as contaminants of potential concern because they are known human carcinogens. 
Aluminum, barium, bromide, chromium, silver, thallium, and tin were eliminated from further assessment at New Rifle because no detectable levels were measured in any of the on-site or downgradient monitor wells or because detection limits were too high to be meaningful.

Antimony, cobalt, lead, and nickel were detected very infrequently in one or more of the shallow on-site wells during the 1990 to 1994 test period. The data are insufficient for a statistical comparison. Prior to 1990, however, these constituents appeared at measurable levels numerous times in shallow on-site wells very near the tailings pile, suggesting the constituents may be associated with uranium milling, but are generally insoluble/immobile. These four constituents were not subjected to additional statistical evaluation or quantification, but were included and discussed qualitatively in the risk assessment.

On-site concentrations of arsenic, cadmium, fluoride, phosphate, selenium, vanadium, and zinc were compared to background levels using the Wilcoxon rank-sum test. With the exception of fluoride, these constituents generally were below detection downgradient of the site, and had a low frequency of detection even on the site itself. The remaining constituents (ammonium, calcium, chloride, iron, magnesium, manganese, molybdenum, nitrate, potassium, silica, sodium, strontium, sulfate, and uranium) generally are present in detectable concentrations in both bac̈kground and plume waters. For these constituents, ANOVA was used to determine if the mean concentration in one or more plume wells exceeds the mean of the three locations representing background.

These statistical analyses identified 20 constituents that are higher in on-site or downgradient wells than in background in the alluvial aquifer at the New Rifle site (Table 3.5). As discussed for the alluvial water quality at New Rifle, antimony, lead, cobalt, and nickel are also included on the list.

\section{Wasatch Formation water quality at the New Rifle site}

Background water quality for the weathered portion of the Wasatch Formation at the New Rifle site is described using water quality data from Old Rifle monitor wells RFO-01-0620/-0622 and New Rifle well RFN-01-0641. Since 1990, monitor well 620 has been sampled six times, 622 has been sampled two times, and 641 has been sampled eight times.

Water quality data from New Rifle on-site wells RFN-01-0611/-0613, and -0624 were used in the statistical comparisons with background. Table 3.2 summarizes background and on-site water quality in the weathered portion of the Wasatch Formation at the New Rifle site. In that table, background data are pooled, and on-site concentrations reflect the wells with the highest average concentration of the constituent. 
Table 3.5 Contaminants of potential concern for human health evaluation for the alluvial aquifer at the New Rifle, Colorado, site

\begin{tabular}{|c|c|c|c|}
\hline $\begin{array}{c}\text { Contaminants } \\
\text { that exceed } \\
\text { background levels }\end{array}$ & $\begin{array}{c}\text { Contaminants in } \\
\text { nutritional } \\
\text { range }\end{array}$ & $\begin{array}{l}\text { Contaminants of low } \\
\text { toxicity and/or high } \\
\text { dietary range }\end{array}$ & $\begin{array}{l}\text { Contaminants of } \\
\text { potential concern }\end{array}$ \\
\hline $\begin{array}{l}\text { Ammonium } \\
\text { Antimony }^{\mathrm{a}} \\
\text { Arsenic } \\
\text { Calcium } \\
\text { Cadmium } \\
\text { Chloride } \text { Cobalt }^{\mathrm{a}} \\
\text { Fluoride } \\
\text { Iron }^{\mathrm{L}} \\
\text { Lead }^{\mathrm{a}} \\
\text { Manganese } \\
\text { Molybdenum } \text { Nickel } \\
\text { Nitrate } \\
\text { Phosphate } \\
\text { Potassium } \\
\text { Selenium } \\
\text { Silica } \\
\text { Strontium } \\
\text { Sodium } \\
\text { Sulfate } \\
\text { Uranium } \\
\text { Vanadium } \\
\text { Zinc }\end{array}$ & $\begin{array}{l}\text { Calcium } \\
\text { Phosphate } \\
\text { Potassium } \\
\text { Zinc }\end{array}$ & $\begin{array}{l}\text { Cobalt }^{\mathrm{a}} \\
\text { Nickel }^{\mathrm{a}} \\
\text { Silica } \\
\text { Strontium }\end{array}$ & $\begin{array}{l}\text { Ammonium } \\
\text { Antimony }^{\mathrm{a}} \\
\text { Arsenic } \\
\text { Cadmium } \\
\text { Chloride } \\
\text { Fluoride } \\
\text { Iron } \\
\text { Lead }^{\mathrm{a}} \\
\text { Manganese } \\
\text { Molybdenum } \\
\text { Nitrate } \\
\text { Selenium } \\
\text { Sodium } \\
\text { Sulfate } \\
\text { Uranium }^{\mathrm{b}} \\
\text { Vanadium } \\
\text { Lead-210 }^{\mathrm{b}} \\
\text { Polonium-210 } \\
\text { Radium-226 } \\
\text { Thorium-230 }\end{array}$ \\
\hline
\end{tabular}


Cadmium, cobalt, chromium, lead, nickel, silver, thallium, and tin were eliminated from further assessment because detectable levels were not measured or because of their extremely low frequency of detection in any on-site wells. For the remaining constituents, the data from the three background wells were pooled and compared to pooled data from the three New Rifle plume wells $(611,613$, and 624). Water quality data from the three plume wells were similar enough to justify pooling the data. The Wilcoxon rank-sum test was used for all comparisons.

Results of these statistical analyses identified 19 constituents that are higher in on-site wells than in background in the weathered portion of the Wasatch formation at the New Rifle site (Table 3.6).

\subsubsection{Toxicity screening for contaminants of potential concern}

Site-related contaminants identified by statistical methods are evaluated for toxicity to human health using the health-based criteria below. Although present above background, several constituents were screened from further assessment because first, their concentrations are within acceptable nutritional ranges or second, they are within an expected dietary range. The criteria for an acceptable nutritional range are based on the National Research Council recommended dietary allowance (RDA) (National Research Council, 1989). Criteria for expected dietary range are based on data from the Agency for Toxic Substances and Disease Registry, the EPA Integrated Risk Information System (IRIS) (EPA, 1994a), and the Handbook on the Toxicology of Metals (Friberg et al., 1986). These publications identify common intake rates for specific macro- and micronutrients. A third criteria for screening a constituent from further evaluation is based on a contaminant's degree of toxicity. Constituent toxicity is considered low when the anticipated intake levels fall well below any known adverse health effect level found in the literature. The 95 percent upper confidence limit for the mean concentration in the most contaminated on-site or downgradient wells (TAC, 1994) was used to estimate an exposure point concentration for comparison with literature values known to cause any adverse health effect. The baseline risk assessment supplement contains contaminantspecific data used to determine contaminants of potential concern (TAC, in preparation).

Data screening from the Old Rifle site retained arsenic, fluoride, iron, manganese, molybdenum, selenium, sulfate, uranium, and vanadium as contaminants of potential concern for human health (Table 3.4). At the New Rifle site, ammonium, arsenic, cadmium, chloride, fluoride, iron, manganese, molybdenum, nitrate, selenium, sodium, sulfate, uranium, and vanadium remained as contaminants of potential concern for human health (Table 3.5) in the alluvium. Antimony and lead remained as contaminants of potential concern in the New Rifle alluvium for a qualitative toxicity assessment. Also for a qualitative assessment, ammonium, antimony, arsenic, chloride, fluoride, iron, manganese, molybdenum, selenium, sodium, sulfate, uranium, and vanadium remained as contaminants of potential concern for the New Rifle weathered 
Table 3.6 Contaminants of potential concern for human health evaluation in the weathered Wasatch Formation aquifer at the New Fifle, Colorado, site

\begin{tabular}{|c|c|c|c|}
\hline $\begin{array}{l}\text { Contaminants that } \\
\text { exceed background } \\
\text { levels }\end{array}$ & $\begin{array}{l}\text { Contaminants; in } \\
\text { nutritional range }\end{array}$ & $\begin{array}{l}\text { Contaminants of low } \\
\text { toxicity and/or high } \\
\text { dietary range }\end{array}$ & $\begin{array}{l}\text { Contaminants of } \\
\text { potential concern }\end{array}$ \\
\hline $\begin{array}{l}\text { Ammonium } \\
\text { Antimony } \\
\text { Arsenic } \\
\text { Calcium } \\
\text { Chloride } \\
\text { Fluoride } \\
\text { Iron } \\
\text { Manganese } \\
\text { Magnesium } \\
\text { Molybdenum } \\
\text { Potassium } \\
\text { Selenium } \\
\text { Silica } \\
\text { Strontium } \\
\text { Sodium } \\
\text { Sulfate } \\
\text { Uranium } \\
\text { Vanadium } \\
\text { Zinc }\end{array}$ & $\begin{array}{l}\text { Zinc } \\
\text { Magnesium } \\
\text { Potassium }\end{array}$ & $\begin{array}{l}\text { Calcium } \\
\text { Silica } \\
\text { Strontium }\end{array}$ & $\begin{array}{l}\text { Ammonium } \\
\text { Antimony } \\
\text { Arsenic } \\
\text { Chloride } \\
\text { Fluoride } \\
\text { Iron } \\
\text { Manganese } \\
\text { Molybdenum } \\
\text { Selenium } \\
\text { Sodium } \\
\text { Sulfate } \\
\text { Uranium } \\
\text { Vanadium } \\
\text { Lead-210 } \\
\text { Polonium-210 } \\
\text { Radium-210 } \\
\text { Thorium-230 }\end{array}$ \\
\hline
\end{tabular}

${ }^{a}$ All radionuclides detected were retained as contaminants of potential concern because they are known human carcinogens. 
Wasatch Formation (Table 3.6). Toxicity profiles for these contaminants are presented in Section 5.0.

Uranium was statistically above background in the ground water at the Old Rifle and the New Rifle sites, and both chemical (noncarcinogenic) and radiological (carcinogenic) risks associated with uranium in ground water are evaluated in this risk assessment. Other monitored radioactive progeny of uranium (thorium230, radium-226, polonium-210, and lead-210) were not analyzed for their presence above background in the ground water under the sites, but were included in the evaluation of carcinogenic risks because these radionuclides are known human carcinogens (Section 6.2). Arsenic also was evaluated as a carcinogen.

The 1992 risk assessment identified 16 contaminants of potential concern for human health. Barium and chromium are the only constituents previously evaluated that were not evaluated in this risk assessment. The more thorough analysis of background ground water quality in this assessment did not identify these constituents as elevated at either the Old or New Rifle sites. Therefore, they were eliminated from further toxicity screening.

Because ground water discharges to the surface water, the contaminants of potential concern for surface water and sediment were assumed to be the same as those for ground water.

\subsection{CONTAMINANT FATE AND TRANSPORT}

The contaminants of potential concern for human health listed in Section 3.3 were evaluated for contaminant fate and transport. Contaminants are transported at the site by ground water flow in the alluvium and Wasatch Formation. Mobility, uptake, and toxicity depend on the species of ions that exist in the aqueous environment. The type of ion species and complexes depend on anion and cation availability for the formation of complex ions and on $\mathrm{pH}$ and Eh conditions. The $\mathrm{pH}$ conditions in the bulk of the alluvium are near neutral (close to 7) but slightly lower near the former tailings piles (near 6.8). The Wasatch Formation tends to have higher pH values (generally near 8 or above, particularly in the deeper screened wells) but contaminated wells have $\mathrm{pH}$ values that resemble alluvial pH (6.8 to 7). Eh conditions in both units are variable, ranging from slightly to strongly oxidizing (50 to $570 \mathrm{mV}$ ). Stable species of the contaminants of concern were computed with the geochemical speciation code PHREEQE (Parkhurst et al., 1980) using the constituent concentrations and Eh-pH conditions observed in the most contaminated wells in each unit at each area. Table 3.7 summarizes the predominant species and their molar percentages. The following discussions of each contaminant of potential concern focus on the alluvium at New Rifle because overall, it is the most contaminated unit at the Rifle sites, and the New Rifle site has better well coverage. Additionally, examination of Table 3.7 shows speciation is similar in both units at both sites. 
Table 3.7 Stable species of constituents of concern in the ground water system, Rifle, Colorado, site, at observed Eh and $\mathrm{pH}$ conditions

\begin{tabular}{|c|c|c|c|c|c|c|c|}
\hline $\begin{array}{l}\text { Conteminant } \\
\text { of potential } \\
\text { concern } \\
\end{array}$ & $\begin{array}{c}\text { Valence } \\
\text { state } \\
\end{array}$ & Common nime & $\begin{array}{l}\text { Identity of } \\
\text { species in } \\
\text { ground water }\end{array}$ & Appr & imate & olar pe & entage \\
\hline & & & & A & B & C & D \\
\hline Antimony" & $\begin{array}{l}5+ \\
3+\end{array}$ & $\begin{array}{l}\text { Antimony hexahydroxide } \\
\text { Antimony trihydroxide }\end{array}$ & $\begin{array}{l}\mathrm{Sb}(\mathrm{OH})_{8}{ }^{1-} \\
\mathrm{Sb}(\mathrm{OH})_{3} \mathrm{AO}\end{array}$ & \multicolumn{4}{|c|}{$\begin{array}{l}\text { Dominant } \\
\text { Secondary }\end{array}$} \\
\hline Arsenic & $\begin{array}{l}5+ \\
5+\end{array}$ & $\begin{array}{l}\text { Hydrogen arsenate } \\
\text { Dihydrogen aresnate }\end{array}$ & $\begin{array}{l}\mathrm{HAsO}^{2-} \\
\mathrm{H}_{2} \mathrm{AsO}^{1 \%}\end{array}$ & $\begin{array}{l}73 \\
27\end{array}$ & $\begin{array}{l}65 \\
35\end{array}$ & $\begin{array}{l}77 \\
23\end{array}$ & $\begin{array}{l}75 \\
25\end{array}$ \\
\hline Cadmium & $\begin{array}{l}2+ \\
2+ \\
2+ \\
2+ \\
2+ \\
2+\end{array}$ & $\begin{array}{l}\text { Cadmium sulfate } \\
\text { Cadmium ion } \\
\text { Cadmium disulfate } \\
\text { Cadmium bicarbonate } \\
\text { Cadmium chloride } \\
\text { Cadmium carbonate }\end{array}$ & $\begin{array}{l}\mathrm{CdSO}_{4} \mathrm{AO} \\
\mathrm{Cd}^{2+} \\
\mathrm{Cd}\left(\mathrm{SO}_{4}\right)_{2}{ }^{2-} \\
\mathrm{CdHCO}_{3}{ }^{++} \\
\mathrm{CdCl}^{1+} \\
\mathrm{CdCO}_{3} \mathrm{AO}\end{array}$ & $\begin{array}{r}31 \\
24 \\
23 \\
9 \\
7 \\
4\end{array}$ & $\begin{array}{r}21 \\
44 \\
2 \\
15 \\
10 \\
8\end{array}$ & $\begin{array}{r}21 \\
46 \\
2 \\
15 \\
2 \\
2 \\
14\end{array}$ & $\begin{array}{r}30 \\
28 \\
15 \\
8 \\
13 \\
5\end{array}$ \\
\hline Chlorine & $1-$ & Chloride & $\mathrm{Cl}^{1-}$ & 100 & 100 & 100 & 100 \\
\hline Fluoride & $1-$ & Fluoride ion & $F^{1-}$ & 95 & 90 & 91 & 89 \\
\hline Iron & $\begin{array}{l}3+ \\
2+ \\
2+\end{array}$ & $\begin{array}{l}\text { Iron dihydroxide } \\
\text { Ferrous ion } \\
\text { Iron sulfate }\end{array}$ & $\begin{array}{l}\mathrm{FeOH}_{2}{ }^{1+} \\
\mathrm{Fe}^{2+} \\
\mathrm{FeSO}_{4} \mathrm{AO}\end{array}$ & 97 & $\begin{array}{r}93 \\
1\end{array}$ & $\begin{array}{l}78 \\
21\end{array}$ & $\begin{array}{r}1 \\
62 \\
36\end{array}$ \\
\hline Lead & $\begin{array}{l}2+ \\
2+ \\
2+\end{array}$ & $\begin{array}{l}\text { Lead carbonate } \\
\text { Lead (II) sulfate } \\
\text { Lead bicarbonate }\end{array}$ & $\begin{array}{l}\mathrm{PbCO}_{3} \mathrm{AQ} \\
\mathrm{PbSO}_{4} \mathrm{AQ} \\
\mathrm{PbHCO}_{3}{ }^{1+}\end{array}$ & $\begin{array}{l}61 \\
14 \\
12\end{array}$ & $\begin{array}{r}74 \\
6 \\
13\end{array}$ & $\begin{array}{r}83 \\
4 \\
8\end{array}$ & $\begin{array}{l}65 \\
13 \\
11\end{array}$ \\
\hline Manganese & $\begin{array}{l}2+ \\
2+\end{array}$ & $\begin{array}{l}\text { Manganese ion } \\
\text { Manganese sulfate }\end{array}$ & $\begin{array}{l}\mathrm{MN}^{2+} \\
\mathrm{MnSO}_{4} \mathrm{AO}\end{array}$ & $\begin{array}{l}55 \\
41\end{array}$ & $\begin{array}{l}74 \\
21\end{array}$ & $\begin{array}{l}75 \\
21\end{array}$ & $\begin{array}{l}60 \\
36\end{array}$ \\
\hline Molybdenum & $6+$ & Molybdate ion & $\mathrm{MoO}_{4}{ }^{2-}$ & 100 & 100 & 100 & 100 \\
\hline Nitrogen & $\begin{array}{l}5+ \\
3+ \\
3- \\
3-\end{array}$ & $\begin{array}{l}\text { Nitrate ion } \\
\text { Nitrite ion } \\
\text { Ammonium ion } \\
\text { Ammonium sulfate }\end{array}$ & $\begin{array}{l}\mathrm{NO}_{3}{ }^{1-} \\
\mathrm{NO}_{2}{ }^{1-} \\
\mathrm{NH}_{4}{ }^{1+} \\
\mathrm{NH}_{4} \mathrm{SO}_{4}{ }^{1-}\end{array}$ & $\begin{array}{l}90 \\
10\end{array}$ & $\begin{array}{r}6 \\
94\end{array}$ & $\begin{array}{r}96 \\
4\end{array}$ & $\begin{array}{l}86 \\
14\end{array}$ \\
\hline Selenium & $\begin{array}{l}4+ \\
4+\end{array}$ & $\begin{array}{l}\text { Hydrogen selenite } \\
\text { Selenite }\end{array}$ & $\begin{array}{l}\mathrm{HSeO}^{{ }^{1-}} \\
\mathrm{SeO}_{3}{ }^{2-}\end{array}$ & \multicolumn{4}{|c|}{$\begin{array}{l}\text { Dominant } \\
\text { Secondary }\end{array}$} \\
\hline Sodium & $1+$ & Sodium ion & $\mathrm{Na}^{1+}$ & 93 & 98 & 98 & 94 \\
\hline Sulfur & $\begin{array}{l}6+ \\
6+\end{array}$ & $\begin{array}{l}\text { Sulfate ion } \\
\text { Calcium sulfate }\end{array}$ & $\begin{array}{l}\mathrm{SO}_{4}{ }^{2 \cdot} \\
\mathrm{CaSO}_{4} \mathrm{AO}\end{array}$ & $\begin{array}{r}84 . \\
6\end{array}$ & $\begin{array}{l}74 \\
14\end{array}$ & $\begin{array}{l}72 \\
19\end{array}$ & $\begin{array}{r}73 \\
7\end{array}$ \\
\hline Uranium & $\begin{array}{l}6+ \\
6+ \\
6+\end{array}$ & $\begin{array}{l}\text { Uranyl tricarbonate } \\
\text { Uranyl dicarbonate } \\
\text { Uranyl biphosphate }\end{array}$ & $\begin{array}{l}\mathrm{UO}_{2}\left(\mathrm{CO}_{3}\right)_{3}^{4-} \\
\mathrm{UO}_{2}\left(\mathrm{CO}_{3}\right)_{2}^{2-} \\
\mathrm{UO}_{2} \mathrm{HPO}_{4}^{2-}\end{array}$ & $\begin{array}{l}76 \\
12 \\
12\end{array}$ & $\begin{array}{l}39 \\
50 \\
10\end{array}$ & $\begin{array}{r}2 \\
1 \\
97\end{array}$ & $\begin{array}{l}80 \\
20\end{array}$ \\
\hline Vanadium & $\begin{array}{l}5+ \\
5+ \\
5+ \\
\end{array}$ & $\begin{array}{l}\text { Vanadate } \\
\text { Vanadate } \\
\text { Vanadate } \\
\end{array}$ & $\begin{array}{l}\mathrm{HV}_{2} \mathrm{O}_{7}{ }^{3-} \\
\mathrm{H}_{2} \mathrm{VO}_{4}{ }^{{ }^{1-}} \\
\mathrm{HVO}_{4}{ }^{2-}\end{array}$ & $\begin{array}{r}92 \\
7 \\
1 \\
\end{array}$ & $\begin{array}{r}11 \\
82 \\
6 \\
\end{array}$ & $\begin{array}{r}84 \\
14 \\
2 \\
\end{array}$ & $\begin{array}{r}66 \\
30 \\
4 \\
\end{array}$ \\
\hline
\end{tabular}

"From Rai and Zachara (1984).

A - New Rifle downgradient alluvial monitor well 590 during the August 1994 sampling round.

B - Old Rifle alluvial monitor well 584 during the November 1992 sampling round.

C - Old Rifle alluvial monitor well 583 during the November 1992 sampling round.

D - New Rifle Wasatch Formation downgradient monitor well 611 during the March 1994 sampling round.

Note: Aqueous species were calculated using the geochemical code PHREEOE (Parkhurst et al., 1980). Information for some species was taken from Rai and Zachara (1984). 


\section{Ammonium and nitrate}

The New Rifle site has ammonium concentrations up to $1750 \mathrm{mg} / \mathrm{L}$ and nitrate concentrations of up to $1110 \mathrm{mg} / \mathrm{L}$. These constituents are near background levels at Old Rifle. At New Rifle, ammonium concentrations tend to be high near the tailings pile and tend to diminish as ground water moves downgradient. Conversely, nitrate concentrations are low near the pile and increase downgradient. This is because ammonium was used in the milling process and entered the ground water at the tailings pile where some of the ammonium oxidized to nitrate in the oxygen-rich ground water at the site. Because nitrate is highly mobile under almost all conditions, dilution and dispersion will be the primary controls on concentrations of this species. Because the Wasatch Formation at New Rifle is more reducing than the alluvium, ammonium species are more stable in the Wasatch Formation (Table 3.7). However, ammonium is strongly adsorbed by clays and would be expected to attenuate in the clay-rich Wasatch Formation.

\section{Antimony}

Antimony is present at both sites at concentrations of up to $0.044 \mathrm{mg} / \mathrm{L}$, but generally is present at lower concentrations (less than $0.03 \mathrm{mg} / \mathrm{L}$ ). The high concentrations are directly under the tailings pile at each site or immediately downgradient. All the known antimony compounds are very soluble; therefore, precipitation is not expected to control concentrations at the site. While very little is known about adsorption/desorption behavior of antimony species (Rai and Zachara, 1984), adsorption appears to have attenuated concentrations of this ion in both areas of the site.

\section{$\underline{\text { Arsenic }}$}

Arsenic is present up to $1.3 \mathrm{mg} / \mathrm{L}$ in on-site well RFN-01-0594 at New Rifle (near the vanadium ponds) but concentrations are at or near detection in downgradient wells, due to adsorption onto the aquifer matrix. The highest concentrations at Old Rifle are much lower $(0.24 \mathrm{mg} / \mathrm{L})$ and are apparent only in the alluvium directly under the tailings pile. Thus, data for the Rifle sites demonstrate that with transport and time, arsenic has been greatly attenuated by adsorption and further attenuation is expected with time.

\section{Cadmium}

Cadmium is present at New Rifle at values of up to $0.13 \mathrm{mg} / \mathrm{L}$ in monitor well RFN-01-0619 (directly adjacent to the southwest corner of the tailings pile) but is generally less than $0.025 \mathrm{mg} / \mathrm{L}$ in downgradient wells. Cadmium was not detected at Old Rifle. Equilibrium with the mineral otavite $\left(\mathrm{CdCO}_{3}\right)$ may limit solution concentrations of cadmium species (Rai and Zachara, 1984) and modeling with PHREEOE (Parkhurst et al., 1980) indicates ground water at the Rifle sites is in equilibrium with otavite. Thus, most cadmium in the ground water has precipitated in the subsurface near the source of contamination. 


\section{Chloride}

Chloride concentrations in the most contaminated ground water are about 4 times background. Chloride is a nonreactive ion and is mobile in ground water. Therefore, decreases in chloride concentrations will be due to dilution and dispersion without the benefit of adsorption.

\section{Fluoride}

Near the tailings pile at New Rifle, fluoride concentrations in most wells vary from 2 to $9 \mathrm{mg} / \mathrm{L}$. Further from the pile, concentrations in individual wells are lower (from less than 1 to $5 \mathrm{mg} / \mathrm{L}$ ) and concentration-versus-time plots show stability over time. This stability suggests fluoride is in equilibrium with solubility-controlling solids. Modeling with PHREEOE (Parkhurst et al., 1980) indicates downgradient wells at both sites are in equilibrium with the mineral fluorite $\left(\mathrm{CaF}_{2}\right)$. Thus, fluoride is precipitating as fluorite as it moves downgradient. These deposits will form a secondary source of fluoride that will continue to release fluoride in equilibrium amounts (from less than 1 to about $5 \mathrm{mg} / \mathrm{L}$ ) until the solids are completely dissolved.

Iron

Iron concentrations near $17 \mathrm{mg} / \mathrm{L}$ at the New Rifle site fall to less than $0.1 \mathrm{mg} / \mathrm{L}$ within $500 \mathrm{ft}(150 \mathrm{~m})$ down gradient of the tailings pile. Iron is soluble under acid or reducing conditions but forms insoluble hydrated oxides under oxidizing conditions at $\mathrm{pH}$ values greater than 6 . Ground water in all downgradient wells is oversaturated with respect to these iron oxides and with time, oxygen is expected to diffuse into the ground water and iron concentrations will decrease to background levels $(1.2 \mathrm{mg} / \mathrm{L})$, due to both precipitation and dilution.

\section{Lead}

Lead is generally below detection (less than $0.01 \mathrm{mg} / \mathrm{L}$ ) at both Rifle sites but concentrations as high as $0.08 \mathrm{mg} / \mathrm{L}$ have been observed directly beneath the tailings pile at New Rifle. Adsorption has been effective in removing lead from ground water, and further decreases in lead are expected in the future.

\section{Manganese}

Manganese is present at New Rifle in concentrations as high as about $10 \mathrm{mg} / \mathrm{L}$. At Old Rifle, manganese is generally below background. Several ground water samples at the New Rifle site are at or near saturation with respect to the mineral rhodochrosite $\left(\mathrm{MnCO}_{3}\right)$, and in the past, manganese probably precipitated out of solution as rhodochrosite. These deposits will form a secondary source of mangariese that will continue to release manganese in equilibrium amounts (about I to $10 \mathrm{mg} / \mathrm{L}$ ) until the solids are completely dissolved. As a result, decreases in concentration will be due to dilution and dispersion without the benefit of adsorption. 


\section{Molybdenum}

Molybdenum is present at both sites. At Old Rifle, molybdenum is limited to concentrations of about $0.1 \mathrm{mg} / \mathrm{L}$ or less but at New Rifle molybdenum is present at concentrations up to about $3 \mathrm{mg} / \mathrm{L}$. Molybdenum occurs in the contaminated ground water as molybdate $\left(\mathrm{MoO}_{4}{ }^{2-}\right)$, a negatively charge ligand (Table 3.7). As with most negatively charged ligands, molybdenum adsorption is most effective under acid conditions (pH of approximately 3 to 4). Thus, molybdenum adsorption in the near-neutral pH ground water at Rifle will be less important than dilution as a mechanism for decreasing concentrations.

\section{Selenium}

Selenium occurs at both Rifle sites at concentrations of up to $0.069 \mathrm{mg} / \mathrm{L}$. The dominant selenium species in ground water at both sites is hydrogen selenite $\left(\mathrm{HSeO}_{3}\right)$ followed by selenite $\left(\mathrm{SeO}_{3}{ }^{2-}\right)$ (Table 3.7). Adsorption of these selenium anionic species is most effective under acid conditions ( $\mathrm{pH}$ less than 4). Thus, under the near-neutral $\mathrm{pH}$ conditions at the site, both anionic species are mobile in ground water and are increasing in some areas as $\mathrm{pH}$ increases. Therefore, dilution and dispersion are likely to be the primary reducing mechanisms for selenium concentrations at the site.

\section{Şodium}

Sodium occurs as a contaminant at both sites, at concentrations of up to about $3900 \mathrm{mg} / \mathrm{L}$. Sodium forms very soluble bicarbonate, chloride, and sulfate salts; thus, those salts will not precipitate. A primary mechanism for sodium removal is cation exchange for calcium within clay minerals. However, the alluvium at the Rifle sites appears to have little cation exchange capacity. Therefore, dilution and dispersion will be most effective in decreasing sodium concentrations in this area.

\section{Sulfate}

Sulfate is a contaminant at both Rifle sites, occurring at concentrations of up to about $12,000 \mathrm{mg} / \mathrm{L}$ at the New Rifle site, and up to about $1500 \mathrm{mg} / \mathrm{L}$ at the Old Rifle site. The sulfate ion $\left(\mathrm{SO}_{4}{ }^{2-}\right)$ is the dominant sulfur species in ground water at the site, followed by calcium sulfate $\left(\mathrm{CaSO}_{4}{ }^{\circ}\right)(\mathrm{Table} 3.7)$. Modeling with the computer code PHREEQE (Parkhurst et al., 1980) indicates gypsum is at equilibrium and should tend to precipitate. These precipitates would then become a secondary source of contamination, supplying sulfate to the ground water in equilibrium concentrations (1000 to $2000 \mathrm{mg} / \mathrm{L}$ ) until solids are completely dissolved.

\section{Uranium}

Uranium concentrations at New Rifle are up to about $0.4 \mathrm{mg} / \mathrm{L}$ and at Old Rifle up to about $2 \mathrm{mg} / \mathrm{L}$. Uranium occurs in ground water at the New Rifle site 
dominantly as a uranyl carbonate complex (for example, $\mathrm{UO}_{2}\left(\mathrm{CO}_{3}\right)_{3}{ }^{4-}$ ) $($ Table 3.7). This complex is mobile in neutral-to-alkaline ground water. Modeled uranium species in monitor well RFO-01-0584 (on the site, upgradient of the tailings pile) at Old Rifle resemble those in ground water at New Rifle (Table 3.7). Uranium occurs in ground water in monitor well RFO-01-0583 (beneath the tailings pile) at the Old Rifle site primarily as uranyl biphosphate $\left(\mathrm{UO}_{2} \mathrm{HPO}_{4}{ }^{2-}\right)$. This complex is also likely to be mobile; therefore, during oxidizing conditions dilution will be the primary control on uranium concentrations as ground water enters the Colorado River.

\section{Vanadium}

Vanadium occurs at both sites, but relatively high concentrations (up to about $2.8 \mathrm{mg} / \mathrm{L}$ ) are restricted to the New Rifle site. With the oxidizing conditions at the site, vanadium exists in ground waters in its maximum oxidation state $(5+)$ as a vanadate ion (primarily $\mathrm{HV}_{2} \mathrm{O}_{7}{ }^{3-}$ ) (Table 3.7). Modeling with PREEQE does not indicate the presence of solubility-controlling solids, thereby arguing against the possibility of attenuation by precipitation. Little is known about the adsorptive behavior of vanadium species, but vanadates are known to be adsorbed by iron oxides (Rai and Zachara, 1984). Overall, vanadium appears to be mobile at the Rifle sites; therefore, dilution and dispersion will be the primary reducing mechanisms for coricentrations in ground water. 


\subsection{EXPOSURE ASSESSMENT}

This section discusses and quantifies the potential exposures that could be incurred by current or future residents, recreational users, and others who use ground water or surface water in the vicinity of the Old and New Rifle processing sites. The methodology is consistent with the EPA guidance on exposure assessments (EPA, 1989b), which recommends analysis based on a reasonable maximum exposure under both current and future land-use conditions. Reasonable maximum exposure is defined as the greatest exposure that can reasonably be expected to occur, based on the current evaluation of onand off-site conditions. Both current and potential future ground water use scenarios are based on current domestic ground water use in the region.

Similar processing activities occurred at the New and Old Rifle sites, resulting in similar ground water contamination beneath the two sites. However, the magnitude and extent of ground water contamination varies between the two sites and between aquifers.

Contamination is generally greatest in the alluvium at both sites with higher levels at New Rifle than at Old Rifle. Contaminant levels are generally lower in the Wasatch Formation at New Rifle. In this exposure assessment, the overlying alluvium and the underlying weathered Wasatch Formation are viewed as a single water-bearing unit where possible exposure could occur because ground water mixing can occur between these hydrologic zones. Although the magnitude and extent of contamination in ground water in each of these units are addressed independently in Section 3.0, this exposure assessment focuses on the greatest levels observed for the contaminants of potential concern in each hydrogeologic unit at the New Rifle site. The Wasatch Formation at the Old Rifle site has not been characterized.

This exposure assessment uses ground water quality data that were collected before complete site characterization. Therefore, future impacts on water quality from the completion of remedial action, and the time and distance effects on contaminant transport that are expected to decrease contaminant concentrations are uncertainties that cannot be quantified with the available data. However, these impacts and effects will be addressed in the Rifle site observational work plan under the UMTRA Ground Water Project.

\subsection{POTENTIALLY EXPOSED POPULATION}

Exposure can only occur if there are contamination, a mechanism of transport, and a receptor. Contaminated ground water in the immediate vicinity of the Old and New Rifle processing sites is not currently used for drinking water. Most residences within a $2-\mathrm{mi}(3-\mathrm{km})$ radius of the sites are supplied by the Rifle municipal water supply. Some county residents and commercial sites outside the city limits do not access city water and use private ground water wells.

The assessment of background water quality and the hydrogeologic system for the Ritle area indicates the private wells in the vicinity of the sites have not been impacted by contaminated ground water and are not expected to be impacted in the future. 
However, one private commercial well (RFN-01-0428) is approximately $3 \mathrm{mi}$ $(5 \mathrm{~km})$ downgradient of the New Rifle site. According to the manager at the commercial site, the ground water from this well is not used for drinking water (Marshall, 1995). Bottled water is supplied to the employees daily because the poor taste of water from this well precludes its use as drinking water. Well water is used for the sewage system only. Because ground water is not used for drinking water at this location, the exposure pathway is incomplete and adverse human health effects cannot occur. Additionally, this well probably is recharged from a different ground water formation than the Rifle sites and the extent of the contaminant plume at the New Rifle site has not been completely characterized. Therefore, the source of the constituents (e.g., plume indicators nitrate, sulfate, and uranium) in this well has not been determined.

Consequently, because of the incomplete exposure pathway and the uncertainty associated with the source of the constituents in this well, this risk assessment does not evaluate exposure in this well. However, when the New Rifle plume is characterized as part of the site observational work plan, well RFN-01-0428 will be reevaluated to determine if it is affected by contamination from the New Rifle site. The potential for human health exposure will also be reevaluated at that time.

Although there are no current: human receptors of contaminated ground water at or adjacent to the processing sites, future domestic ground water use is assessed for a residential population, given the potential for property development at or downgradient of the New Rifle site or at the Old Rifle site. Contaminant levels found in ground water in the heart of the plume were used to estimate the reasonable maximum future exposures for the contaminants of potential concern at each site if land immediately on or adjacent to the processing sites were developed and ground water were accessed for domestic purposes.

The potentially exposed population includes individuals of the following age groups: infants (birth to 1 year old), children (1 to 10 years old), and adults (11 to 64 years old). These age groups were selected because survey data for population variables such as age, weight, and daily water intake are available for these age groups, and because toxicological variables are similar within these age groups. These similarities include responsiveness of sensitive subgroups (infants and children) to the contaminants of potential concern, toxicant intake to body weight ratios, and toxicokinetics.

Specific sensitive subpopulations and/or individuals could be more vulnerable to the estimated potential exposures than the general public. A sensitive subpopulation could be people with existing illness or individuals who have multiple exposures to these constituents. Also, any of the three age groups investigated could show a greater sensitivity to particular contaminants of potential concern. Potentially sensitive subpopulations are addressed directly where applicable and when clata are available. 


\subsection{EXPOSURE PATHWAYS}

An exposure pathway describes the course a contaminant takes from the source to the exposed individual. There must be a source of contamination, a point of contact with a population or individual, and a route of exposure (e.g., water ingestion) to complete a pathway. Evaluating potential exposure pathways involves determining not only the most likely pathways but also the major contributing pathways to risk as a function of exposure dose. This assessment evaluates both direct and indirect exposures to contaminated ground water. Given the chemical properties of the inorganic contaminants of potential concern at UMTRA Project sites, direct exposure through drinking water ingestion is expected to result in the most significant contaminant exposure dose. The main contributions to risk are identified by a screening process that compares exposures through the drinking water pathway to exposures through other pathways.

Ground water in the region of the Rifle sites is used for household purposes such as cooking, gardening, and bathing. Although ground water could be used for drinking, it usually is replaced by city water or bottled water because of the naturally poor water quality of shallow ground water in the region. Ground water is not commonly used for large-scale irrigation or livestock watering because of the ample availability of surface water. However, incidents of using ground water to water gardens and livestock have been recorded. Indirect exposure to ground water could occur through ground water impacts on surface water and sediment. Figure 4.1 provides a conceptual model of the potential ground water exposure pathways that may occur at the Rifle sites. Figure 4.2 outlines the potential current and future receptors considered for the Rifle screening exposure scenarios.

\subsubsection{Drinking water ingestion}

It is unlikely that ground water at either the Old or New Rifle site will be used in the future for drinking purposes because of the availability of a municipal water supply. However, drinking water ingestion generally is the most significant exposure pathway to ground water contaminated with metals and other nonvolatile compounds. In this evaluation, drinking water consumption includes water ingested by drinking and consuming food prepared with water le.g., reconstituted juices, soup, rice, and beans). A screening level assessment of contaminant intakes through drinking water is shown in Table 4.1. These calculations are based on the reasonable maximum exposure concentrations (95 percent upper confidence limit [UCL] for the mean) of the contaminants of potential concern both at the New Rifle and Old Rifle sites. Data were compiled from the most contaminated monitor wells at each site and represent a single exposure point dose. 


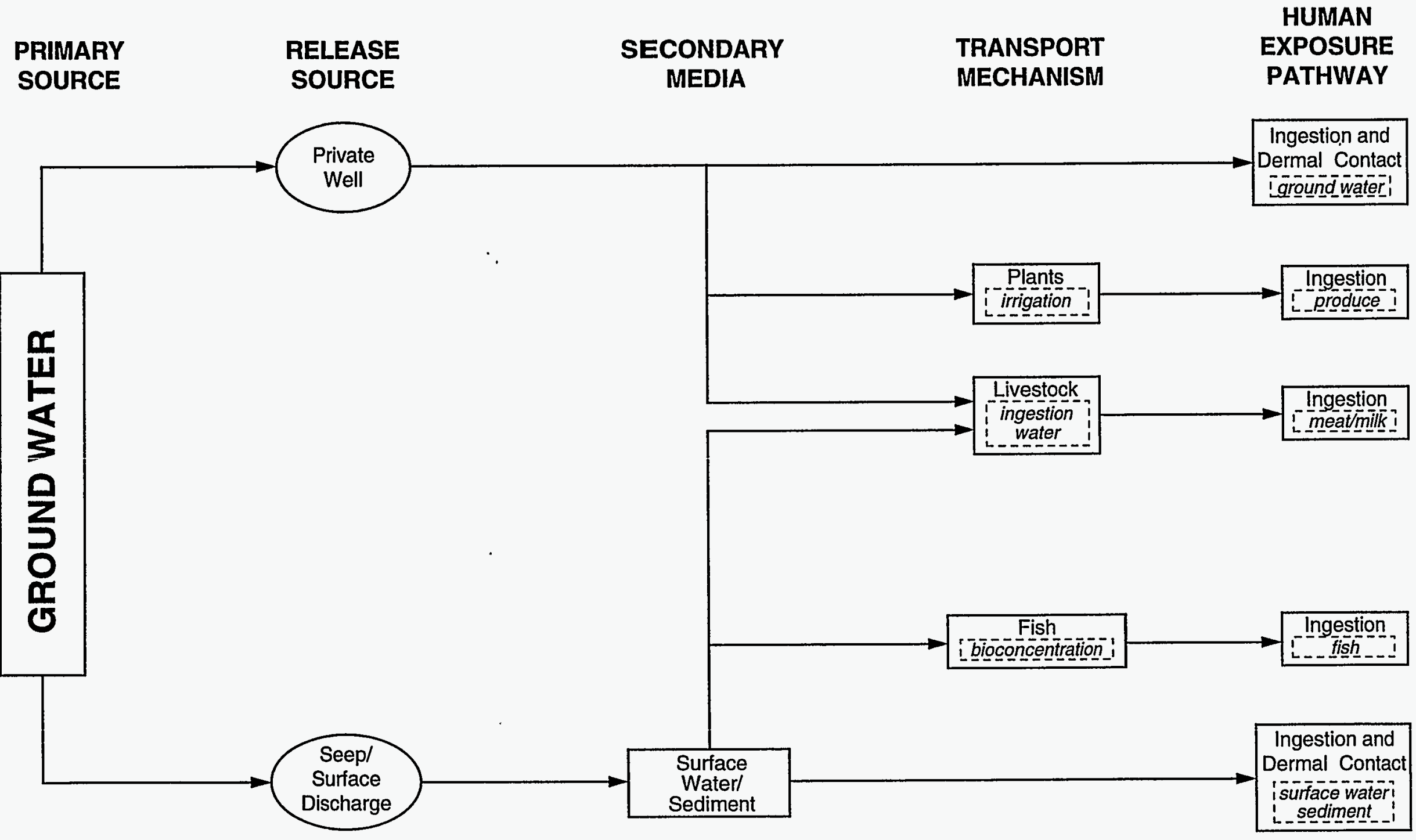

FIGURE 4.1

RIFLE, COLORADO, SITE CONCEPTUAL MODEL 


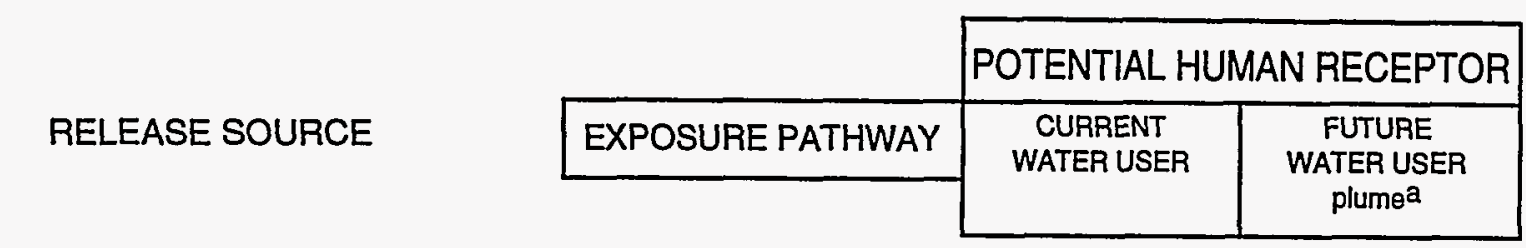

\begin{tabular}{|c|c|c|c|}
\hline \multicolumn{4}{|l|}{ GROUND WATER } \\
\hline 4 & INGESTION & 0 & - \\
\hline$\perp$ & INGESTION MEAT/MILK & O & 0 \\
\hline SURFACE WATER & DERMAL CONTACT & 0 & - \\
\hline & INGESTION PRODUCE & 0 & 0 \\
\hline \multirow[b]{2}{*}{1} & INGESTION & $\bullet^{b}$ & $\bullet_{\operatorname{Rec}}$ \\
\hline & INGESTION FISH & $0_{\text {Rec }}$ & $0_{\text {Rec }}$ \\
\hline SEDIMENT & DERMAL CONTACT & Rec & $0_{\mathrm{ReC}}$ \\
\hline
\end{tabular}

\section{LEGEND}

- POTENTIAL EXPOSURE SCENARIO ASSESSED QUANTITATIVELY

O EXPOSURE SCENARIO NOT ASSESSED

a FUTURE POTENTIAL USE OF GROUND WATER IN THE MOST CONTAMINATED WELLS

b RECREATIONAL (ReC) LOCATION

FIGURE 4.2

SCREENING EXPOSURE SCENARIOS FOR POTENTIAL HUMAN RECEPTORS RIFLE, COLORADO, SITES 


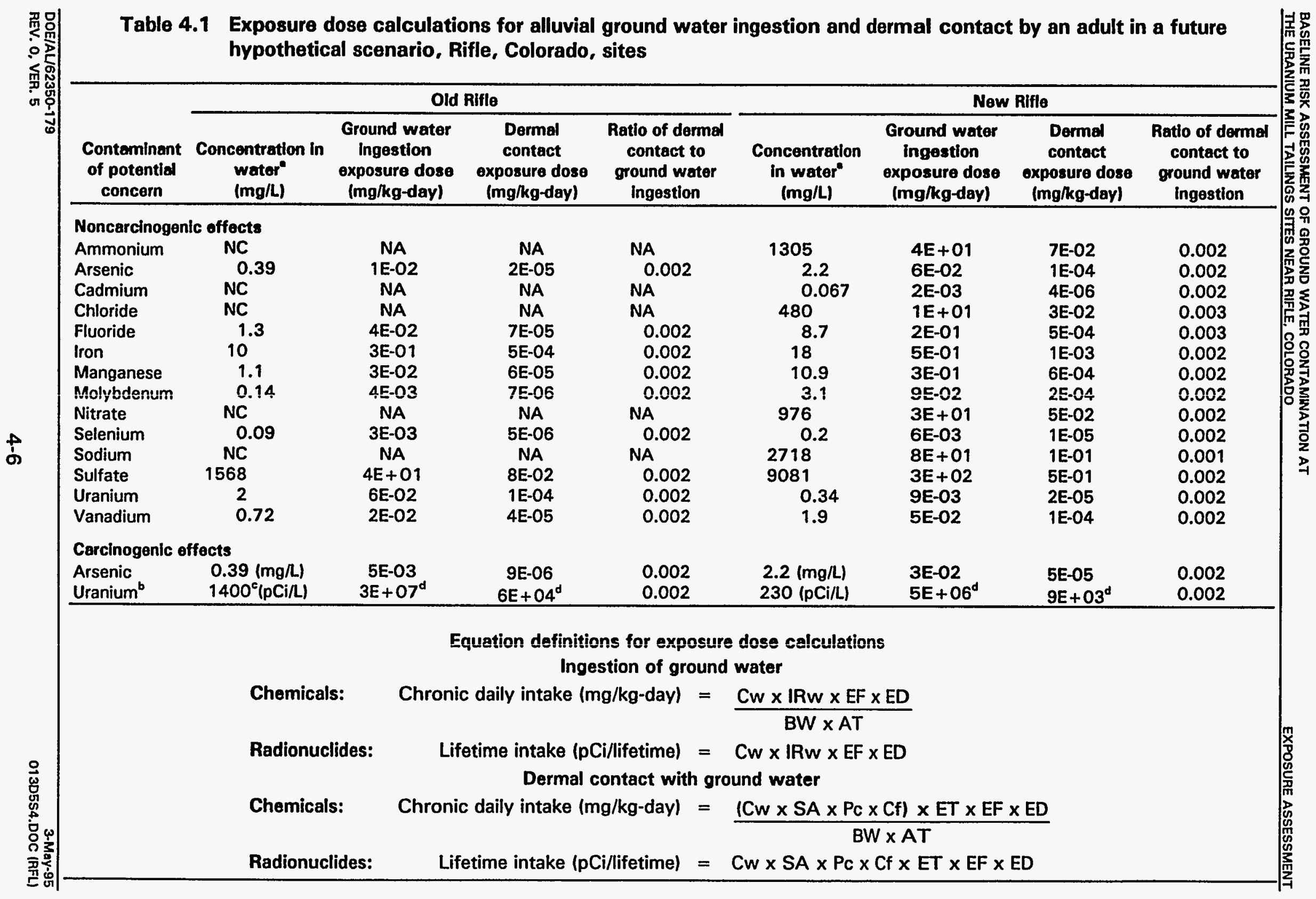




\subsubsection{Dermal contact}

Dermal absorption is the process by which chemicals coming into contact with the skin become absorbed into the blood vessels near the surface of the skin. Although some compounds are absorbed easily in this rnanner, inorganics usually are absorbed poorly through intact skin. Because chemical-specific absorption factors are not available for these contaminants, they are assumed to absorb across the skin at the same rate as water (EPA, 1992a). This assumption is believed to overestimate any potential dose contribution from dermal contact. Although the dermal dose is an absorbed dose, and only a percentage of the ingested dose will be absorbed, the screening calculation that compares it to the ground water ingestion route (Table 4.1 ) shows a very low contribution from dermal absorption (much less than 1 percent for each contaminant of potential concern). Because the assumptions used to estimate dermal absorption likely overestimate the dose and adverse health effects would not be expected at such low doses, dermal absorption is considered insignificant compared to ingestion and is not evaluated further in this risk assessment. Its significance as an independent source of exposure is discussed relative to the risks associated with the drinking water pathway in Section 6.0.

Dermal contact to surface water and sediment through swimming is possible at the Old Rifle pond. Although the pond is not a designated swimming area and no one has been observed swimming in the pond, access is not restricted. Tables 4.2 and 4.3 present screening calculations for children exposed to surface water and sediment while swimming in the Old Rifle pond. Exposure doses from these pathways are relatively insignificant compared to exposure through drinking water ingestion. However, the possible impacts of these exposure pathways are discussed further in Section 6.0.

\subsubsection{Ingestion of ground water-irrigated produce}

Contaminants in ground water could be taken up by plants either through roots in saturated soils or through irrigation water. Large-scale irrigation with ground water is not considered a pathway because surface water is the main source of irrigation water in the Rifle area. Irrigation of garden plants and subsequent ingestion of contaminated produce is a potential future exposure pathway. Currently, not enough data exist in the literature to determine potential exposures from this pathway because the estimation of contaminant uptakes by plants from water is uncertain. Therefore, this risk assessment does not present a screening calculation for exposure through plants. The UMTRA Ground Water Project is conducting a study of contaminant uptake by vegetables and grasses irrigated with contaminated ground water. When these data become available, this pathway will be evaluated further.

Section 7.0 presents a screening evaluation of the potential environmental impacts of contaminated ground water on natural vegetation. 
Table 4.2 Exposure dose calculations for incidental surface water ingestion and dermal contact for children swimming in Old Rifle pond, Rifle, Colorado, sites

\begin{tabular}{|c|c|c|c|c|c|c|c|}
\hline \multirow{2}{*}{$\begin{array}{c}\text { Contaminant } \\
\text { of potential } \\
\text { concern } \\
\end{array}$} & \multirow{2}{*}{$\begin{array}{c}\text { Concentration } \\
\text { in surface } \\
\text { water } \\
\text { (mg/L) } \\
\end{array}$} & \multirow{2}{*}{$\begin{array}{c}\text { Ingestion } \\
\text { surface water } \\
\text { exposure dose } \\
\text { (mg/kg-day) } \\
\end{array}$} & \multicolumn{2}{|c|}{$\begin{array}{c}\text { Ratio of surface } \\
\text { water ingestion to } \\
\text { ground water } \\
\text { ingestion }\end{array}$} & \multirow{2}{*}{$\begin{array}{c}\text { Dermal } \\
\text { contact } \\
\text { exposure dose } \\
\text { (mg/kg-day) } \\
\end{array}$} & \multicolumn{2}{|c|}{$\begin{array}{c}\text { Ratio of surface } \\
\text { water dermal contact } \\
\text { to ground water } \\
\text { ingestion }\end{array}$} \\
\hline & & & Old Rifle & New Rifle & & Old Rifle & New Rifle \\
\hline \multicolumn{8}{|c|}{ Noncarcinogenic effects } \\
\hline $\begin{array}{l}\text { Fluoride } \\
\text { Iron } \\
\text { Manganese } \\
\text { Sulfate } \\
\text { Uranium }\end{array}$ & $\begin{array}{c}0.24 \\
0.22 \\
0.15 \\
59 \\
0.017\end{array}$ & $\begin{array}{l}8 E-05 \\
7 E-05 \\
5 E-05 \\
2 E-02 \\
6 E-06\end{array}$ & $\begin{array}{l}0.002 \\
0.0002 \\
0.002 \\
0.0005 \\
0.0001\end{array}$ & $\begin{array}{l}0.0004 \\
0.0001 \\
0.0002 \\
0.00007 \\
0.0007\end{array}$ & & $\begin{array}{l}0.0005 \\
0.00007 \\
0.0003 \\
0.0001 \\
0.00002\end{array}$ & $\begin{array}{l}0.0001 \\
0.00004 \\
0.00003 \\
0.00001 \\
0.0001\end{array}$ \\
\hline \multicolumn{8}{|c|}{ Carcinogenic effects } \\
\hline & 12 & $4 E+02^{c}$ & 0.00001 & 0.00008 & $8 \mathrm{E}+01^{\mathrm{c}}$ & 0.000003 & 0.00002 \\
\hline
\end{tabular}

\section{Equation definitions for exposure dose calculations}

Incidental ingestion of surface water

Chemicals: Chronic daily intake $\left(\mathrm{mg} / \mathrm{kg}\right.$-day) $=\frac{\text { Csw } \times \text { IRsw } \times \text { EF } \times \text { ED } \times \text { ET }}{B W \times A T}$

Radionuclides: $\quad$ Lifetime intake $(p C i / l i f e t i m e)=C s w \times$ IRsw $\times E F \times E D \times E T$

Dermal contact with surface water

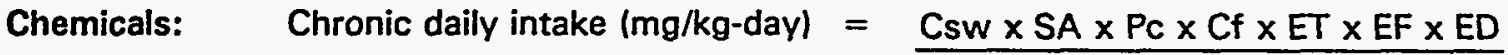
$B W \times A T$

Radionuclides: Lifetime intake (pCi/lifetime) $=\mathrm{Csw} \times \mathrm{SA} \times \mathrm{Pc} \times \mathrm{CF} \times \mathrm{ET} \times \mathrm{EF} \times \mathrm{ED}$

Where:

Csw = Maximum contaminant concentration in surface water (milligrams per liter or picocuries per liter).

IRsw = Incidental ingestion rate for surface water $10.05 \mathrm{~L}$ per hour for 6 - to 12 -year-old children) (EPA, 1989b).

Cf = Conversion factor $(0.001$ liters per cubic centimeter)

$\mathrm{EF}=$ Exposure frequency (90 days per year; 3 months per year for 7 days per week).

$\mathrm{ED}=$ Exposure duration (7 years for 6 - to 12 -year-old children).

$\mathrm{BW}=$ Body weight (38.3 kg; based on 90 th percentile body weight for 6 - to 12 -year-old male children) (EPA, 1989a).

$A T=$ Averaging time (365 days $\times$ ED for noncarcinogens) (365 days $\times 70$ years for carcinogens) (EPA, $1989 \mathrm{bl}$.

$\mathrm{SA}=$ Skin surface area $110,937 \mathrm{~cm}^{2}$ for 6 - to 12 -year-old children; based on 50 th percentile total body surface area) (EPA, 1989a).

PC = Dermal permeability constant $(0.001 \mathrm{~cm}$ per hour) (EPA, $1989 \mathrm{~b})$.

ET = Exposure time (1 hour per day).

\footnotetext{
Based on maximum detected value in surface water (sampling location RF0-01-0572).

Uranium-234 and uranium-238 combined; $1 \mathrm{mg}$ uranium is assumed to equal $686 \mathrm{pCi}$.

Enits are picocuries per lifetime.
} 
Table 4.3 Exposure dose calculations for incidental sediment ingestion and dermal contact for children swimming in Old Rifle pond, Rifle, Colorado, sites

\begin{tabular}{|c|c|c|c|c|c|c|c|}
\hline \multirow{2}{*}{$\begin{array}{c}\text { Conteminant } \\
\text { of potential } \\
\text { concern }\end{array}$} & \multirow{2}{*}{$\begin{array}{l}\text { Concentration } \\
\text { in sediment } \\
\text { (mg/kg) }\end{array}$} & \multirow{2}{*}{$\begin{array}{c}\text { Ingestion } \\
\text { sediment } \\
\text { exposure dose } \\
\text { (mg/kg-day) }\end{array}$} & \multicolumn{2}{|c|}{$\begin{array}{l}\text { Ratio of sediment to } \\
\text { ground water ingestion }\end{array}$} & \multirow{2}{*}{$\begin{array}{c}\text { Dermal contact } \\
\text { sedinent } \\
\text { exposure dose } \\
\text { (mg/kg-day) }\end{array}$} & \multicolumn{2}{|c|}{$\begin{array}{l}\text { Ratio of sediment } \\
\text { dermal contact to } \\
\text { ground water ingestion }\end{array}$} \\
\hline & & & Old Rifle & New Rifle & & Old Rifle & New Rifle \\
\hline \multicolumn{8}{|c|}{ Noncarcinogenic offects } \\
\hline Arsenic & 9.3 & $6 \mathrm{E}-06$ & 0.0006 & 0.0001 & 7E-07 & 0.00007 & 0.00001 \\
\hline Cadmium & 6.4 & 4E-06 & NA & 0.002 & $5 E-07$ & NA & 0.0003 \\
\hline Iron & 16000 & 1E-02 & 0.03 & 0.02 & $1 E-03$ & 0.003 & 0.002 \\
\hline Manganese & 394 & $3 E-04$ & 0.01 & 0.001 & $3 E-05$ & 0.001 & 0.0001 \\
\hline Selenium & 1.7 & 1E-06 & 0.0003 & 0.0002 & 1E-07 & 0.00003 & 0.00002 \\
\hline Uranium & 8.2 & $5 E-06$ & 0.00008 & 0.0006 & $6 E-07$ & 0.00001 & 0.00007 \\
\hline Vanadium & 45.8 & 3E-05 & 0.002 & 0.0006 & $3 E-06$ & 0.0002 & 0.00006 \\
\hline Zinc & 860 & 6E-04 & NA & & & NA & \\
\hline \multicolumn{8}{|c|}{ Carcinogenic effects } \\
\hline Arsenic & $9.3(\mathrm{mg} / \mathrm{kg})$ & $6 \mathrm{E}-07$ & 0.0001 & 0.00002 & 7E-08 & 0.00001 & 0.000002 \\
\hline Uranium $^{b}$ & $5600(\mathrm{pCi} / \mathrm{kg})$ & $9 E+01^{c}$ & 0.000003 & 0.00002 & $4 E+01^{c}$ & 0.000001 & 0.000008 \\
\hline
\end{tabular}

Equation definitions for exposure dose calculations Incidental ingestion of sediment

Chemicals: Chronic daily intake (mg/kg-day) $=\frac{\text { Csd } \times \text { Cf } \times \text { IRsd } \times \text { EF } \times \text { ED }}{B W \times A T}$

Radionuclides: $\quad$ Lifetime intake ( $p$ Ci/lifetime) $=$ Csd $\times$ Cf $\times$ IRsd $\times$ EF $\times$ ED

Chemicals: $\quad$ Chronic daily intake $(\mathrm{mg} / \mathrm{kg}$-day) $=$ Csd $\times$ Cf $\times$ SA $\times$ AF $\times$ ABS $\times E F \times E D$ $B W \times A T$

Radionuclides: $\quad$ Lifetime intake $(\mathrm{pCi} /$ lifetime $)=\operatorname{Csd} \times \mathrm{Cf} \times \mathrm{SA} \times \mathrm{AF} \times \mathrm{ABS} \times \mathrm{EF} \times \mathrm{ED}$

Where:

Csd = Contaminant concentration in sediment (maximum concentration) (milligrams per kilogram or picocuries per kilogram).

$\mathrm{Cf}_{\mathrm{f}}=$ Conversion fáctor $\left(10^{-6} \mathrm{mg} / \mathrm{kg}\right)$.

IRsd = Incidental ingestion rate for sediment (100 mg per day for 6- to 12-year-old children) (EPA, 1989b).

$\mathrm{EF}=$ Exposure frequency (90 days per year; 3 months per year for 7 days per week).

ED = Exposure duration (7 years for 6- to 1.2-year-old children).

AF $=$ Soil-to-skin adherence factor $\left(1 \mathrm{mg} / \mathrm{cm}^{2}\right)$.

ABS = Absorption factor (0.001; unitless).

BW = Body weight (38.3 kg; based on 90 th percentile body weight for 6 - to 12 -year-old male children) (EPA, 1989a).

AT = Averaging time (365 days $\times$ ED for noncarcinogens; 365 days $\times 70$ years for carcinogens) (EPA, $1989 \mathrm{bl}$.

SA = Skin surface area $\left(10,937 \mathrm{~cm}^{2}\right.$ for 6- to 12 -year-old children; based on 50 th percentile total body surface area) (EPA, 1989a).

\footnotetext{
Based on maximum detected value in sediment (sampling location RFO-01-0572, Old Rifle pond).

Uranium-234 and uranium-238 combined; $1 \mathrm{mg}$ uranium is assumed to equal $686 \mathrm{pCi}$.

'Units are picocuries per lifetime.

$\mathrm{mg} / \mathrm{kg}$-day - milligrams per kilogram per day.

NA - not applicable, since not above background in ground water.
} 


\subsubsection{Ingestion of milk or meat from ground water-fed livestock}

Contaminants in ground water can enter the food chain through livestock consuming contaminated ground water or surface water. Ground water-fed livestock could concentrate contaminants in their meat or milk, thus providing an ingestion pathway to humans. Surface water is the current primary water source for livestock in the Rifle area. Therefore, any estimate of human exposure to meat or milk would be based on a hypothetical future ground water use scenario. At the New Rifle site, contaminant levels in ground water in the heart of the plume are potentially lethal to livestock. Therefore, this pathway could not be completed at that site. However, contaminated ground water at the Old Rifle site could be given to livestock, which would complete this pathway. Nonetheless, a screening calculation was not done because of the lack of confidence in estimating contaminant uptakes by livestock and because the estimates would contain many uncertainties.

\subsubsection{Fish ingestion}

Recreational fishing occurs at the Old Rifle pond although it is on private land. Contaminated ground water from the Old Rifle site appears to have impacted this downgradient pond.

Fish ingestion represents an exposure route that could increase dietary levels of the contaminants of potential concern for the Old Rifle site. In 1991, a single fish sample was collected and the whole body was analyzed for arsenic, cadmium, chromium, molybdenum, selenium, uranium, vanadium, and radium-226. Arsenic, cadmium, molybdenum, and vanadium were not detected. Chromium and selenium were detected at 2.8 milligrams per kilogram $(\mathrm{mg} / \mathrm{kg})$, uranium was detected at $0.35 \mathrm{mg} / \mathrm{kg}$ (240 picocuries per kilogram [pCi/kg]), and radium-226 was detected at $200 \mathrm{pCi} / \mathrm{kg}$. However, for the fish ingestion exposure pathway, only the contaminants of potential concern that were selected for the ground water are evaluated here. To calculate an exposure dose for these contaminants from eating fish, literature-derived bioconcentration factors (BCF) are used to estimate potential exposures. Table 4.4 presents the results of the screening. An exposure dose could not be calculated for arsenic, fluoride, molybdenum, sulfate, or vanadium because BCFs are not available for these contaminants. However, this screening likely overestimates intake for the contaminants evaluated because it is based on an adult's consuming a daily portion of fish from the Old Rifle pond for $\mathbf{5 2}$ days per year for 30 years. Additionally, for the contaminants of potential concern for which there are tissue data (i.e., selenium and uranium), the screening calculation is based on whole body analyses that likely overestimate the exposure dose to humans because humans consume soft tissue only (not whole body). Section 6.0 discusses risk from this exposure pathway. 
Table 4.4 Exposure dose calculations for adult ingestion of fish from Old Rifle pond, Rifle, Colorado, site

\begin{tabular}{|c|c|c|c|c|c|}
\hline $\begin{array}{l}\text { Contaminant of } \\
\text { potential concern }\end{array}$ & $\begin{array}{c}\text { Concentration in } \\
\text { surface water } \\
\text { (mg/L) }\end{array}$ & $\begin{array}{c}\text { Bioconceritration } \\
\text { factcr" } \\
\text { (unitless) } \\
\end{array}$ & $\begin{array}{c}\begin{array}{c}\text { Concentration } \\
\text { in fish } \\
\text { (mg }\end{array} \\
\end{array}$ & $\begin{array}{l}\text { Fish ingestion } \\
\text { oxposure dose } \\
\text { (mg/kg-day) }\end{array}$ & $\begin{array}{l}\text { Ratio fish ingestion } \\
\text { to ground water } \\
\text { ingestion }\end{array}$ \\
\hline $\begin{array}{l}\text { Noncarcinogenic off } \\
\text { Iron } \\
\text { Manganese } \\
\text { Selenium } \\
\text { Uranium }\end{array}$ & $\begin{array}{c}\text { ffects } \\
0.22 \\
0.15 \\
\text { ND } \\
0.017\end{array}$ & $\begin{array}{l}100 \\
150 \\
6 \\
2\end{array}$ & $\begin{array}{l}22 \\
23 \\
N C \\
0.34\end{array}$ & $\begin{array}{c}1 E-03 \\
1 E-03 \\
\text { INC } \\
2 E-06(2 E-05)^{c}\end{array}$ & $\begin{array}{c}0.003 \\
0.03 \\
0.06 c \\
3 E-05(3 E-04)^{c}\end{array}$ \\
\hline $\begin{array}{l}\text { Carcinoganic effect: } \\
\text { Uranium }\end{array}$ & $12(\mathrm{pCi} / \mathrm{L})^{d}$ & 2 & $24(240)^{c}$ & $1 E+03(1 E+04)^{c, d}$ & $3 E-05(3 E-04)^{c}$ \\
\hline
\end{tabular}

Equation definitions for exposure dose calculations

Ingestion of fish

Chemicals: Chronic daily intake (mg/kg-day) $=\frac{\text { Cf } \times I R \times E F \times E D \times F I}{B W \times A T}$

Radionuclides: Lifetime intake ( $p$ Ci/lifetime) $=\mathrm{Cf} \times \mathrm{IR} \times \mathrm{EF} \times \mathrm{ED} \times \mathrm{FI}$

Where:

Cf = Contaminant concentration in fish (milligrams per kilogram); $\mathrm{CF}=\mathrm{Csw} \times \mathrm{BCF}$.

IR = Ingestion rate of fish $10.054 \mathrm{~kg}$ per day for an adult) (EPA, 1991).

$\mathrm{EF} \quad=$ Exposure frequency (52 days per year) (EPA, 1991).

$E D=$ Exposure duration ( 30 years for an adult) (EPA, 1989b).

$\mathrm{FI}=$ Fraction ingested from contaminated source (0.5 unitless).

BW = Body weight (70 kg for an adult) (EPA, 1989b).

AT = Averaging time ( 365 days $\times$ ED for noncarcinogens) ( $365 \times 70$ years for carcinogens)(EPA, 1989b).

Csw = Contaminant concentration in surface water (maximum concentration) (milligrams per liter).

$B C F=$ Bioconcentration factor (chemical-specific; unitless) (EPA, 1992b).

BCF based on study of minnows (AQUIRE, 1992); converted from dry to wet weight assuming 75 percent moisture in fish tissue (EPA, 1994a).

Based on maximum detected concentration in surface water from sampling location RF0-01-0572, Old Rifle pond.

'Actual fish tissue data for whole-body analysis of a single fish from Old Rifle pond.

Uranium-234 and uranium-238 combined; $1 \mathrm{mg}$ uranium is assumed to equal $686 \mathrm{pCi}$.

ND - not detected.

NTA - not available.

NC - could not be calculated.

$\mathrm{mg} / \mathrm{kg}$-day - milligrams per kilogram per day. 
Impacts to fish from the discharge of contaminated ground water into the Colorado River at either Rifle site is much less likely, due to the large effects of dilution on contaminant levels in the river. Therefore, exposure through ingesting fish from the Colorado River is not evaluated in this risk assessment. Exposure (by dermal absorption) to these contaminants in the Colorado River near the New Rifle site is expected to be negligible and is not evaluated further.

Section 7.0 presents a screening evaluation of the potential direct toxicity of contaminants to fish in the Old Rifle pond and the Colorado River.

\subsubsection{Summary}

The screening assessment shows that the drinking water pathway would contribute the greatest dose to an individual.

Potential intakes of the contaminants of potential concern from the drinking water pathway (as probability distributions) and the corresponding to these estimates are evaluated in Section 6.0. Intakes of some of the contaminants of potential concern could be increased by the additional exposure pathways evaluated. Therefore, the potential additive impacts from the other exposure pathways evaluated (dermal contact with ground water, ingestion and dermal contact with surface water, and sediment and fish ingestion) are also discussed in Section 6.0.

\subsection{EXPOSURE CONCENTRATIONS ;}

The exposure concentration of a contaminant in ground water is the concentration taken in by an individual over the period of exposure considered. In this evaluation, chronic exposures of contaminant concentrations are assumed to remain in a steady state (i.e., not trending up or down with time) during the residence periods. Contaminant concentrations (and therefore exposures) are actually expected to decrease with time after the completion of surface remedial action to remove the tailings. Nonetheless, exposure concentrations based on current on-site conditions are used to conservatively estimate chronic exposure.

To evaluate noncarcinogenic risk, contaminant concentrations (expressed as probability distributions) are used to estimate intake distributions with Monte Carlo simulation. Concentration distributions provide the probability of occurrence of a range of contaminant concentrations rather than of a single value. The statistical specifications for individual contaminant concentration distributions for the contaminants of potential concern at both the Old and New Rifle sites are listed in Table 4.5. The distribution (normal or lognormal) selected for cor.nputing the UCL was used as the theoretical probability distribution for the contaminant concentrations. The mean and standard deviation of the theoretical distribution were set equal to the observed mean and standard deviation of the sample data from the worst wells on the site. For quantitative risk evaluation, the tails of the distribution were truncated (i.e., values below 
Table 4.5 Probability distribution specifications for contaminant concentrations for the alluvium at the Old and New Rifle sites and Wasatch Formation at the New Rifle site

\begin{tabular}{|c|c|c|c|c|c|}
\hline Constituents & Location & $\begin{array}{c}\text { Distribution } \\
\text { type }\end{array}$ & $\begin{array}{l}\text { Mean } \\
\text { (mg/L) }\end{array}$ & $\begin{array}{c}\text { Standard } \\
\text { deviation } \\
\text { (mg/L) }\end{array}$ & $\begin{array}{c}\text { 99th } \\
\text { percentile } \\
\text { (mg/L) }\end{array}$ \\
\hline \multicolumn{6}{|l|}{ Ammonium } \\
\hline & Old Rifle alluvium & - & - & - & - \\
\hline & New Rifle alluvium & LN & 1095 & 375 & 2248 \\
\hline & New Rifle Wasatch & $\mathbf{N}$ & 882 & 400 & 1819 \\
\hline \multicolumn{6}{|l|}{ Arsenic } \\
\hline & Old Rifle alluvium & LN & 0.24 & 0.09 & 0.52 \\
\hline & New Rifle alluvium & $\mathbf{N}$ & 1.14 & 0.23 & $\begin{array}{l}1.70 \\
0.027\end{array}$ \\
\hline \multicolumn{6}{|l|}{ Cadmium } \\
\hline & Old Rifle alluvium & - & - & - & - \\
\hline & New Rifle alluvium & LN & 0.034 & 0.029 & 0.14 \\
\hline & New Rifle Wasatch & - & - & - & - \\
\hline \multicolumn{6}{|l|}{ Chloride } \\
\hline & Old Rifle alluvium & - & - & - & - \\
\hline & New Rifle alluvium & $\mathbf{N}$ & 429 & 149 & 777 \\
\hline & New Rifle Wasatch & $\mathbf{N}$ & 743 & 211 & 1250 \\
\hline \multicolumn{6}{|c|}{ 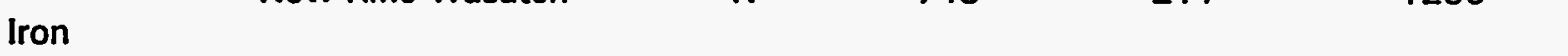 } \\
\hline & Old Rifle alluvium & $\mathbf{N}$ & 8.4 & 2.6 & 14.5 \\
\hline & New Rifle alluvium & $\mathbf{N}$ & 16.7 & 0.3 & 17.4 \\
\hline & New Rifle Wasatch & $\mathbf{N}$ & 14.4 & 1.9 & 18.8 \\
\hline \multicolumn{6}{|l|}{ Fluoride } \\
\hline & Old Rifle alluvium & $\mathbf{N}$ & 1.2 & 0.1 & 1.5 \\
\hline & New Rifle alluvium & $\mathbf{N}$ & 7.6 & 0.9 & 9.8 \\
\hline & New Rifle Wasatch & $\mathbf{N}$ & 7.1 & 0.5 & 8.2 \\
\hline \multicolumn{6}{|l|}{ Manganese } \\
\hline & Old Rifle alluvium & LN & 1.09 & 0.06 & 1.22 \\
\hline & New Rifle alluvium & LN & 10.4 & 1.3 & 13.8 \\
\hline & New Rifle Wasatch & $\mathbf{N}$ & 6.7 & 1.2 & 9.5 \\
\hline \multicolumn{6}{|l|}{ Molybdenum } \\
\hline & Old Rifle alluvium & $\mathbf{N}$ & 0.10 & 0.04 & 0.19 \\
\hline & New Rifle alluvium & $\mathbf{N}$ & 2.96 & 0.44 & 4.0 \\
\hline & New Rifle Wasatch & $\mathbf{N}$ & 1.70 & 0.82 & 3.6 \\
\hline \multicolumn{6}{|l|}{ Nitrate } \\
\hline & Old Rifle alluvium & - & - & - & - \\
\hline & New Rifle alluvium & $\mathbf{N}$ & 831 & 198 & 1313 \\
\hline & New Rifle Wasatch & - & - & - & - \\
\hline \multicolumn{6}{|l|}{ Selenium } \\
\hline & Old Rifle alluvium & $N$ & 0.052 & 0.035 & 0.13 \\
\hline & New Rifle alluvium & $\mathbf{N}$ & 0.16 & 0.07 & 0.32 \\
\hline & New Rifle Wasatch & LN & 0.027 & 0.029 & 0.14 \\
\hline \multicolumn{6}{|l|}{ Sodium } \\
\hline & Old Rifle alluvium & - & - & - & - \\
\hline & New Rifle alluvium & $N$ & 2458 & 710 & 4188 \\
\hline & New Rifle Wasatch & $\mathbf{N}$ & 2835 & 710 & 4486 \\
\hline
\end{tabular}


BASELINE RISK ASSESSMENT OF GROUND WATER CONTAMINATTON AT

THE URANIUM MILL TAILINGS SITES NEAR RIFLE. COLORADO

Table 4.5 Probability distribution specifications for contaminant concentrations for the alluvium at the Old and New Rifle sites and Wasatch Formation at the New Rifle site (Concluded)

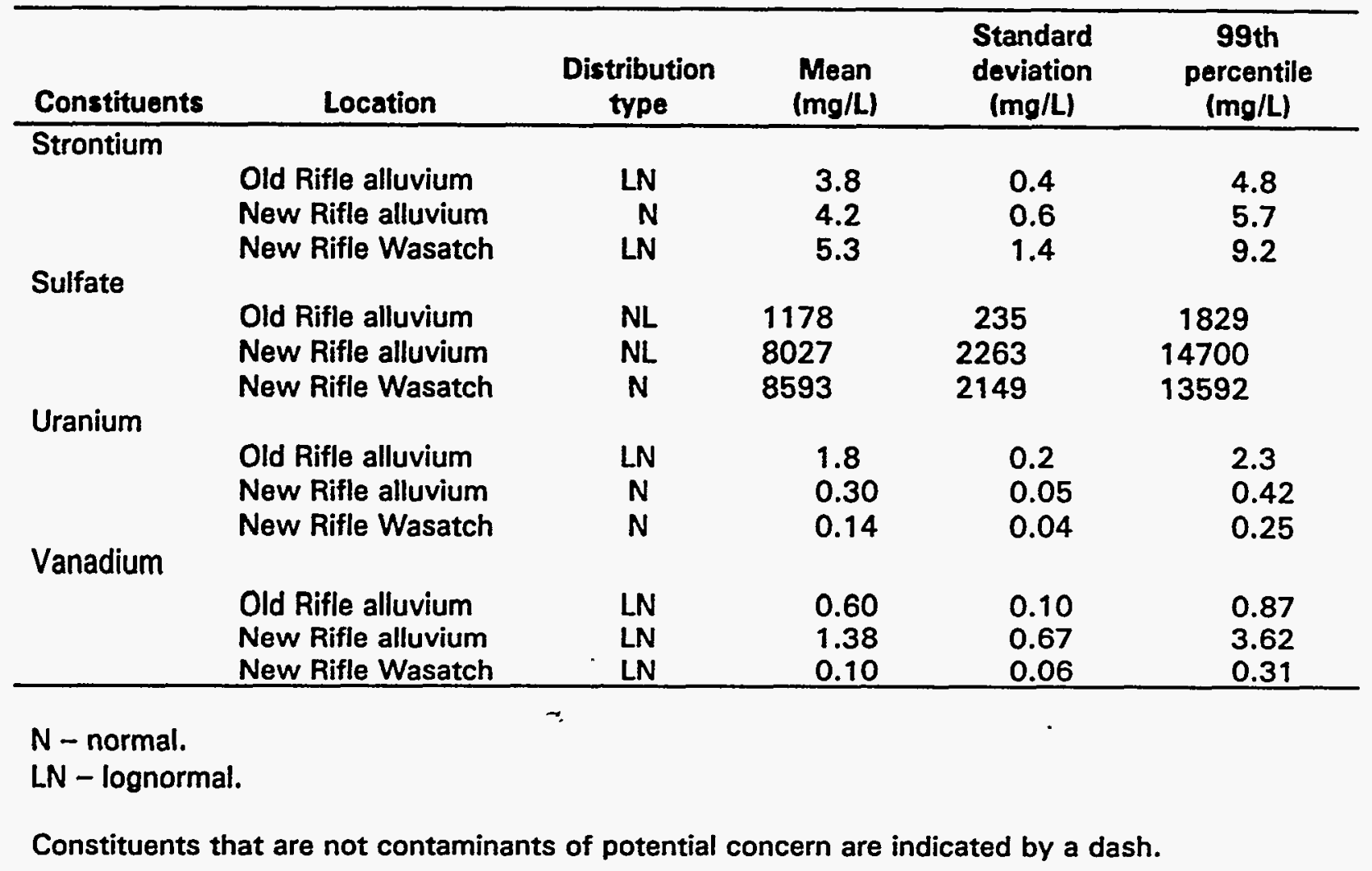


$0.0 \mathrm{mg} / \mathrm{L}$ and above the 99 th percentile of the theoretical probability distribution were assigned zero probability. The probability associated with the disallowed portion was assigned proportionally to the allowable values so that the total probability under the truncated curve remained equal to 1.0. It was verified that this truncation is conservative because the 99th percentile is above the maximum observed concentration in each of the data sets used for this risk assessment.

A single exposure point concentration based on the maximum is used to calculate a conservative intake level in evaluating toxicity from antimony and lead. Antimony and lead could not be evaluated probabilistically due to an insufficient quantity of water quality data. Maximum concentrations were also used to estimate from radionuclides. Because contamination is expected to decrease over time, the use of maximum observed concentrations for chemicals or radionuclides probably will overestimate the potential carcinogenic or noncarcinogenic risks for these specific contaminants of potential concern.

\subsection{ESTIMATION OF INTAKE THROUGH DRINKING WATER}

The potential toxicity of noncarcinogenic contaminants in drinking water depends primarily on long-term average daily consumption of the contaminant per kilogram of body weight measured in milligrams per kilogram per day ( $\mathrm{mg} / \mathrm{kg}$-day). The chemical contaminants of potential concern were evaluated for potential noncarcinogenic effects. Exposures to these contaminants were estimated as a chronic average daily intake relative to body weight. The following equation estimates chronic daily intake:
$(\mathrm{mg} / \mathrm{L})$
(L / day)
(years)
(days / year)

INTAKE $\left(\mathrm{mg} / \mathrm{kg}\right.$ - day) $=\frac{\text { concentration in water } \mathrm{x} \text { water ingestion rate } \mathrm{x} \text { exposure duration } \mathrm{x} \text { exposure frequency }}{\text { body weight } \times \text { averaging time }}$

(kg)

(365 days $x$ exposure duration)

The potential carcinogenicity of chemicals is based on the average daily consumption of the chemical per kilogram of body weight but is averaged over a life span of 70 years. Arsenic is the only chemical carcinogen detected at the Rifle sites, and intake over a lifetime is calculated as follows:
( $\mathrm{mg} / \mathrm{L}$ )
(L / day)
(years)
(days / year)

INTAKE $\left(\mathrm{mg} / \mathrm{kg}\right.$ - day) $=\frac{\text { concentration in water } x \text { water ingestion rate } x \text { exposure duration } x \text { exposure frequencey }}{\text { body weight } x \text { averaging time }}$

(kg)

(365 days $\times 70$ year life span)

Potential carcinogenicity of radioactive carcinogens is additive (increases with total intake over time). Also, body weight is relatively insignificant in determining risk from exposure to radioactive carcinogens. Intake of a 
radioactive carcinogenic substance is quantified as total exposure (measured in picocuries) to radioactivity times the exposure duration, which is calculated as follows:

INTAKE

$(\mathrm{pCi} /$ lifetime $)=$ concentration in water $\mathrm{x}$ water ingestion rate $\mathrm{x}$ exposure duration $\mathrm{x}$ exposure frequency
$(\mathrm{pCi} / \mathrm{L})$
(L / day)
(years)
(days / year)

Exposures to a potential future population will vary according to contaminant concentrations, the exposure frequency and duration, and population variability. Within the population of future residents, individuals are expected to vary in their water consumption habits, stable body weight, and length of residence time in the potential contaminated zone. Consequently, health risks associated with ground water consumption will vary among members of the population. To adequately describe the potential exposure range to a potential future population ingesting ground water, naturally occurring variability in daily intake and body weight were incorporated into the intake simulations. Probability distributions and concentration distributions were formulated and truncated at the upper and lower 0.01 percentile (TAC, in preparation). Within the hypothetical populations, values disallowed through this truncation may occur with a probability of less than 1 in 10,000. Variables used to simulate exposures are discussed below; the statistical methods used are described in the statistical report (TAC, in preparation).

\section{Average daily water intake (liters per dav)}

Lognormal probability distributions were used to describe variation in average daily tap water intake among members of the population (Roseberry and Burmaster, 1992). These distributions were developed from data collected during the 1977-78 National Food Consumption Survey conducted by the U.S. Department of Agriculture. During the survey, total tap water consumption during a 3-day period was recorded for 26,081 survey participants nationwide. Water intake probability distributions were used to simulate an exposure distribution for the contaminants of potential concern (TAC, in preparation).

\section{Body weight (kilograms)}

Extensive national data on weights of males and females, by age, were collected by the National Health and Nutrition Survey between 1976 and 1980 . These data were used to develop lognormal probability distributions for body weight, by age, for each sex. The distributions for males and females were then combined using census data on the national ratio of males to females within each age group. Body weight probability distributions were used in the exposure distribution simulations for the contaminants of potential concern (TAC, in preparation). 


\section{Population distributions (age groups)}

Using the exposure concentration distributions described in Section 4.3 and the intake parameter distributions described below, total intake distributions for a single contaminant were simulated for the following three receptor populations: 0- to 1-year-olds; 1-to 10-year-olds; and 11-to 64-year-olds. Results illustrated the effect of the different age group characteristics on daily intake of noncarcinogens. Intake was observed to be greatest in the 1-to 10-year age group, although the intake for the 0 - to 1-year age group is very similar.

Therefore, the 1- to 10-year age group is used in this risk evaluation to simulate exposures to the contaminants of potential concern for each site. Where data identify one of the other age groups as more sensitive to a particular contaminant, that population is used in the exposure simulation. Because infants are the most susceptible receptors to sulfate and nitrate toxicity, intake distributions for infants were generated for these contaminants.

\section{Exposure duration (vears)}

Children are the receptors of concern that were evaluated for the noncarcinogenic effects of the contaminants of potential concern. A 10-year exposure duration was assumed for 1-to 10-year-old children. A fixed lifetime exposure time of 30 years was used to model lifetime cancer risks in the Rifle area, based on EPA guidance (EPA, 1991). The area has a large stable rural population, although the economic base in the city of Rifle promotes some turnover in the population over time. Because the concentrations of radionuclides in groundwater at the Rifle sites are decreasing with time, risk evaluations based on this exposure duration, combined with historic maximum radionuclide concentrations, yield conservative estimates of carcinogenic risks.

\section{Exposure frequency}

Individuals generally do not stay in their homes and drink water from the same source $\mathbf{3 6 5}$ days per year. Therefore, intake calculations assume a maximum of 350 days exposure per year, allowing 2 weeks per year of drinking-water intake from a different source (EPA, 1991).

\section{Averaging time (days)}

When potential noncarcinogenic effects from longer-term exposures are evaluated, intakes are averaged over the exposure period. Thus, to evaluate the noncarcinogenic effects of the contaminants of potential concern, an averaging time of $\mathbf{3 6 5 0}$ days (i.e., 10 years $\times 365$ days) was used for children.

\section{Simulated exposure distributions}

A distribution of potential exposures is calculated by Monte Carlo simulation. Each simulation repeatedly selects numerical values for each of the input variables (contaminant concentrations, body weight, and ingestion rates), inserts 
the selected values into the equations described above, and calculates the resulting exposure. For each iteration of this process, numerical values are selected according to the probability distributions for the input variable; therefore, numbers with a higher probability of occurrence in the distribution are chosen more frequently. The results are displayed in a distribution graph to indicate the relative likelihood that different exposure levels will occur at a site for each contaminant of potential concern. Values from this distribution indicate the percentage of the exposures predicted to fall above or below an expected (average) reference point, which can be compared to known or estimated toxic effects.

To present risk for both the Old and New Rifle sites, intake distributions for children were generated for the contaminants of potential concern at each site in the alluvium. Distributions for exposures to ground water in the New Rifle Wasatch Formation are not presented graphically but rather discussed qualitatively in relation to exposures from the New Rifle alluvium. Because these two hydrologic units are hydraulically connected, they are considered interchangeable relative to potential risks from exposure to contaminants. In Section 6.0, contaminant intake distributions are compared to potential adverse human health effects associated with these exposures. This graphic presentation of intake and corresponding potential adverse health effects is the basis for the risk evaluation at each site.

\subsection{EXPOSURE ASSESSMENT UNCERTAINTIES}

$>$

Several potential sources of uncertainty may occur in an exposure assessment, including the following more significant sources:

- Uncertainties resulting from the lack of thorough environmental sampling data (ground water, surface water, sediment, biological), which could lead to an underestimation or overestimation in the exposure analysis.

- Uncertainties arising from the assumption that the ground water contaminant source term at the site has reached a steady state and that contaminant concentrations at the exposure point will remain constant for chronic periods of exposure (generally greater than 7 years).

- Uncertainties associated with the relationship of an applied dose (used in this assessment) and absorbed dose or effective toxic dose for dermal absorption.

- Uncertainties related to estimating risk from the produce and meat/milk ingestion pathways, which have not been evaluated.

- Uncertainties associated with different sensitivities of subpopulations, such as individuals with chronic illnesses, that could alter predicted responses to contaminants. 
- Uncertainties associated with the use of filtered ground water samples. The results of exposure assessment presented in this document are based on filtered $(0.45$-micron) ground water samples. Therefore, the potenitial loss of certain ground water constituents as a consequence of filtration represents an additional source of uncertainty (i.e., underestimation of risk from ground water contamination at these sites).

- Uncertainties associated with the exclusion of organic contaminants from consideration as a source of potential exposure. This document evaluates exposures only to inorganic ground water contaminants at the UMTRA Project sites at Old and New Rifle, thereby potentially underestimating risk at these sites.

- Uncertainties with fish BCFs. Site-specific BCFs could vary substantially from default literature values.

Despite these uncertainties, the application of probability distributions that incorporates the definable sources of variability (body weight, water intake, contaminant concentrations) provide a representative picture of the potential range of exposures. 


\subsection{TOXICITY ASSESSMENT}

Several contaminants that could cause adverse human health and environmental effects have been detected in ground water at the mill tailings and pond areas at the Rifle processing sites. The toxicological effects of the chemical contaminants and the carcinogenic potentials of the radionuclides are summarized below.

The following source materials were used to develop toxicological profiles on these chemical contaminants and the potentially carcinogenic radionuclides:

- The IRIS (EPA, 1994a).

- The Agency for Toxic Substances and Disease Registry Toxicological Profiles, published by the Department of Health and Human Services (DHHS).

- The Handbook on the Toxicology of Metals (Friberg et al., 1986).

- Peer-reviewed scientific literature, when these review documents were not available.

Basing toxicity information on the standardized review documents cited above ensures consistency in risk evaluation at all UMTRA Project processing sites.

The toxicity profiles presented here focus on drinking water data in humans. Animal information is used only when human data are,not available. Animal data are represented on the toxicity range graphs by widely spaced dotted lines. Uncertainty about the beginning and ending point of an exposure range that produces specific toxic effects is represented by closely spaced doted lines.

\subsection{CONTAMINANT TOXICITY VALUES}

The EPA Office of Research and Development has calculated acceptable intake values or reference doses (RfDs) for long-term (chronic) exposure to noncarcinogens. These values are estimates of route-specific exposure levels that would not be expected to cause adverse effects when exposure occurs for a significant portion of a lifetime. Some chronic RfDs are adopted as subchronic RfDs. RfDs include safety factors to account for uncertainties associated with limitations of the toxicological database. These safety factors include extrapolating results from animal studies to humans and accounting for response variabilities in sensitive individuals. These values are updated quarterly and are published in the Health Effects Assessment Summary Tables (HEAST) as provisional values (EPA, 1994b). Following more stringent review, they will be published through the EPA's IRIS database as verified values. Table 5.1 summarizes the must recent oral RfDs for the noncarcinogenic contaminants of potential concern. 
Table 5.1 Toxicity valußs: potential noncarcinogenic effects

\begin{tabular}{|c|c|c|c|c|c|}
\hline Chemical & $\begin{array}{c}\text { Chronic oral } \\
\text { RfD } \\
\text { (mg/kg-day) }\end{array}$ & $\begin{array}{c}\text { Confidence } \\
\text { level }\end{array}$ & Critical effect/organ & $\begin{array}{l}\text { RfD basis/RfD } \\
\text { source }\end{array}$ & $\begin{array}{c}\text { Uncertainty } \\
\text { factor }\end{array}$ \\
\hline Ammonium & NA & NA & TBD & NA & NA \\
\hline Antimony & 0.0004 & Low & $\begin{array}{l}\text { Increased mortality/ } \\
\text { altered blood } \\
\text { chemistry }\end{array}$ & Water/HEAST & 1000 \\
\hline $\begin{array}{l}\text { Arsenic } \\
\text { (inorganic) }\end{array}$ & 0.0003 & High & $\begin{array}{l}\text { Keratosis, hyper- } \\
\text { pigmentation }\end{array}$ & Water/HEAST & 3 \\
\hline Cadmium & 0.0005 & High & Kidney & Water/HEAST & 10 \\
\hline Chloride & NA & NA & Hypertension & NA & NA \\
\hline Fluoride & 0.006 & High & Fluorosis, tooth & Water/IRIS & 1 \\
\hline Iron & NA & NA & $\begin{array}{l}\text { Skin pigmentation, } \\
\text { cirrhosis of the liver }\end{array}$ & $\begin{array}{l}\text { Therapeutic } \\
\text { sources/NA }\end{array}$ & NA \\
\hline Lead & NA & NA & $\begin{array}{l}\text { Central nervous } \\
\text { system effect }\end{array}$ & NA & NA \\
\hline Manganese & 0.005 & High & Kidney & Water/HEAST & 10 \\
\hline Molybdenum & 0.005 & High & Bone & Water/HEAST & 2 \\
\hline Nitrate & $7.0^{\circ}$ & High & $\begin{array}{l}\text { Methemoglobenimia, } \\
\text { hematologic }\end{array}$ & Water/IRIS & 1 \\
\hline Selenium & 0.005 & High & Hair, nail, and skin & Diet/IRIS & 3 \\
\hline Sodium & NA & High & Hypertension & Water/diet & NA \\
\hline Sulfate & NA & High & Diarrhea & Water/NA & NA \\
\hline Uranium & 0.003 & Medium & $\begin{array}{l}\text { Nephrotoxicity, } \\
\text { decreased body } \\
\text { weight }\end{array}$ & Water/IRIS & 1000 \\
\hline Vanadium & 0.007 & Low & Hair & Water/IRIS & 100 \\
\hline
\end{tabular}

'Value presented as nitrate; nitrate-nitrogen RfD is $1.6 \mathrm{mg} / \mathrm{kg}$-day.

Note: The uncertainty factor reflects scientific judgment regarding the different types of data used to estimate RfD values. For example, an uncertainty factor of 10 is usually used to account for sensitivity among different populations.

NA - not available.

RfD - reference dose.

TBD - to be determined. 
The EPA currently classifies all radionuclides as Group A, or known human carcinogens, based on their property of emitting ionizing radiation and on evidence from epidemiological studies of radiation-induced cancer in humans. At sufficiently high doses, ionizing radiation acts as a complete carcinogen (both initiator and promoter), capable of increasing the probability of cancer development. However, the actual risk is difficult to estimate, particularly for the low doses and dose rates encountered in the environment. Most reliable data were obtained under conditions of high doses delivered acutely. It is not clear whether cancer risks at lower doses are dose-proportional (i.e., the linear dose-response hypothesis) or whether the risk is greatly reduced at low doses and rates (i.e., the threshold hypothesis). A conservative assumption rejects the threshold hypothesis and assumes that any dose and dose rate add to the risk of cancer.

Toxicity values published in HEAST and IRIS correlate the intake of carcinogens over a lifetime with the increased excess cancer risk from that exposure. Table 5.2 gives the most recent cancer slope factors for the uranium-234/-238 radioactive decay series and the chemical carcinogen arsenic.

\subsection{CONTAMINANT TOXICITY SUMMARIES}

The following summaries address the basic toxicokinetics and toxicity of the chemical contaminants of potential concern at the Rifle processing site. These contaminants are ammonium (characterized by the ammonia toxicity profile), antimony, arsenic, cadmium, chloride, fluoride, iron, lead, manganese, molybdenum, nitrate, selenium, sodium, sulfate, uranium, and vanadium. Although the toxic effects of these contaminants vary with exposure levels, toxic effects.observed in the exposure range most relevant to contamination at this site are discussed in this document.

\subsubsection{Ammonia}

Ammonia $\left(\mathrm{NH}_{3}\right)$ is a gas with a very strong odor that can be smelled when the ammonia concentration in the air exceeds 50 ppm (ATSDR, 1990). In water, ammonia $\left(\mathrm{NH}_{3}\right)$ exists in dynamic equilibrium with ammonium hydroxide $\left(\mathrm{NH}_{4} \mathrm{OH}\right)$, a weak base, which is partially ionized to form $\mathrm{NH}_{4}{ }^{+}$and $\mathrm{OH}^{-}$. The relative amount of $\mathrm{NH}_{4}{ }^{+}$compared to $\mathrm{NH}_{3}$ increases with decreasing $\mathrm{pH}$. At $\mathrm{pH}$ 9.25, half the ammonia is in the form of $\mathrm{NH}_{4}{ }^{+}$in water (ATSDR, 1990). At pH 8.25 and 7.25, 90 percent and 99 percent of the ammonia is in the form of $\mathrm{NH}_{4}{ }^{+}$, with the remaining 1 percent as $\mathrm{NH}_{3}$, in each case. Thus, under environmental conditions ammonia in water solutions does not occur as a gas and is not noticeable by smell. Based on geochemical models for the Rifle site, ammonia exists primarily as the $\mathrm{NH}_{4}{ }^{+}$ion.

\section{Absorption}

Ingested ammonia is readily absorbed from the gastrointestinal tract (ATSDR, 1990). Studies in humans suggest that about 30 to 65 percent of ammonia 
Table 5.2 Toxicity values: carcinogenic effects

\begin{tabular}{|c|c|c|c|c|}
\hline Parameter & $\begin{array}{l}\text { Oral slope } \\
\text { factor } \\
(p)^{-1}\end{array}$ & $\begin{array}{l}\text { Weight of } \\
\text { evidence } \\
\text { classification }\end{array}$ & Type of cancer & $\begin{array}{l}\text { Slope factor } \\
\text { source }\end{array}$ \\
\hline Arsenic & $1.8 \mathrm{E}+00^{\mathrm{a}}$ & A & Skin & IRIS \\
\hline Lead-210 & $1.01 \mathrm{E}-09$ & A & Bone & HEAST \\
\hline Polonium-210 & $3.26 \mathrm{E}-10$ & A & $\begin{array}{l}\text { Liver, kidneys, } \\
\text { spleen }\end{array}$ & HEAST \\
\hline Radium-226 & $2.96 \mathrm{E}-10$ & A & Bone & HEAST \\
\hline Thorium-230 & $3.75 E-11$ & A & b & HEAST \\
\hline Uranium-238 & $6.2 E-11$ & A & c & HEAST \\
\hline Uranium-234 & 4.44E-11 & A & c & HEAST \\
\hline
\end{tabular}

${ }^{a}$ Based on oral unit risk of $5 \times 10^{-5}$ (EPA, 1994a).

bTarget organs or systems have not been identified for oral exposure to thorium.

'No human or animal studies show a definite association between oral exposure to natural uranium and development of cancer. The average slope factor for uranium-238 and -234 is $5.32 \mathrm{E}-11$. 
nitrogen (radio-labeled nitrogen from nitrogen-15-ammonium chloride) is absorbed and metabolized.

Little or no ammonia absorbs into the circulatory system via intact skin, but dermal exposure to ammonia may lead to some inhalation exposure (ATSDR, 1990).

\section{Tissue accumulation and clearance}

In the human gastrointestinal tract, the ammonium ion can be converted to nitrite and nitrate by certain microorganisms or it can be transformed to nitrogen (Casarett and Doull, 1991). The efficiency of this conversion has not been determined for humans, but it may be affected by individual factors such as age.

In healthy individuals, ammonia absorbed from the gastrointestinal tract passes to the liver, where it is metabolized mainly to urea (Summerskill and Wolpert, 1970 ) and readily eliminated from the body. Thus, relatively small amounts of ammonia or ammonium compounds normally reach the circulatory system. However, in individuals with liver disease, large amounts of ammonia absorbed from the gastrointestinal tract can reach the circulatory system through portalsystemic collateral vessels, probably as a result of impaired urea synthesis by the liver.

Un-ionized ammonia is freely diffusible, while the ammonium ion is less so and it is relatively confined to the extracellular compartment (ATSDR, 1990). However, the ammonium ion is in dynamic equilibrium with dissolved ammonia. Therefore, ammonium compounds that enter the circulatory system or other body fluids can penetrate tissue cells as ammonia. Ammonia and its liver metabolites distribute throughout the body; they can be found in the liver, kidney, spleen, heart, and muscle (ATSDR, 1990).

Orally ingested ammonium salts, after being quickly and almost completely converted in the liver, are eliminated from the body primarily as urinary urea (ATSDR, 1990). Approximately 70 percent of a dose of nitrogen-15 was excreted in human urine 3 days after nitrogen-15-labeled ammonium salts were ingested in drinking water; 25 percent $(24$ percent urinary urea and 1 percent urinary ammonia) was eliminated within the first 6 hours after exposure. Small amounts of ammonia are excreted as urea in feces. Ammonia is also known to be excreted via sweat and expired air; however, quantitative information is unavailable.

\section{Environmental sources of ammonia}

Ammonia occurs naturally in the environment predominantly as a result of natural decomposition of plant and animal material and breakdown of fertilizers, urea, and other nitrogenous waste products (ATSDR, 1990). It is an intermediate in the natural nitrogen cycle in nature. In soil or water, plants and microorganisms take up ammonia rapidly. 
The ammonium ion is the dominant form of ammonia in water at $\mathrm{pH}$ ranges occurring naturally in the environment (i.e., in ground water wells, rivers, lakes, and wet soils).

The general population is exposed to low levels of ammonia in air, water, and soil. In water, ammonia volatilizes to the atmosphere; this process is dependent on several variables, including $\mathrm{pH}$ and temperature (ATSDR, 1990).

In surface water, ground water, or sediment, ammonia can be transformed by nitrification and denitrification to produce ionic nitrogen (ATSDR, 1990). Nitrites and nitrates form as a result of the aerobic process of nitrification. Elemental nitrogen produced from the anaerobic process of denitrification is lost by volatization to the atmosphere.

Typical ammonia levels in rivers and bays are less than $6 \mathrm{mg} / \mathrm{L}$ (ATSDR, 1990). The high adsorptivity of ammonium to soil and the rapid conversion of ammonia to nitrate by microbial action result in very low ammonia levels in ground water. The ammonia content of drinking water is not reported in available literature.

In soil, ammonia serves as a nutrient source; it is rapidly taken up by plants and other organisms and converted to organic-nitrogen compounds (ATSDR, 1990). Soil typically contains about 1 to $5 \mathrm{mg} / \mathrm{kg}$ of ammonia, and the greatest ammonia concentrations appear to be in the uppermost 1.6 inches $(4 \mathrm{~cm})$ of soil.

The general population is exposed to excessive levels of ammonia primarily from ammonia-containing household cleaners although ammonia is also a component of tobacco and cigarette smoke.

\section{Toxicity of ammonia}

Ammonia is both a potentially toxic and an essential chemical for humans. Ammonia is endogenously produced in the human digestive tract. Intestinal bacteria produce ammonia from metabolizing dietary proteins, amino acids, and other nitrogen-containing chemicals. Normally about 20 percent of the urea produced in the human body diffuses into the gut, where it is converted by bacteria to ammonia and carbon dioxide (Gilman et al., 1990). This endogenous ammonia serves an important role in nitrogen metabolism and in maintaining an acid-base balance in humans and animals. The total arnmonia produced in the gastrointestinal tract of adult humans is estimated to be about $4200 \mathrm{mg}$ per day (equivalent to about $60 \mathrm{mg} / \mathrm{kg}$-day for a $70-\mathrm{kg}$ adult); the contribution from the colon predominates (greater than 70 percent) (Summerskill and Wolpert, 1970).

In blood, the ammonium ion dissociates slightly to $\mathrm{H}^{+}$and $\mathrm{NH}_{3}$ (ammonia); the dissociation constant is such that, in the $\mathrm{pH}$ blood range, the ammonium $\left(\mathrm{NH}_{4}{ }^{+}\right.$) ion constitutes about 99 percent of the total ammonia $\left(\mathrm{NH}_{3}+\mathrm{NH}_{4}{ }^{+}\right)(\mathrm{Gilman}$ et al., 1990). 
The most important toxic effects of ammonia on humans are from its irritative and corrosive properties. Ingesting concentrated ammonia solutions can produce severe burns and hemorrhage of the upper gastrointestinal tract, which can result in death (ATSDR, 1990). Although human deaths from excessive oral ingestion of ammonia have been attributed to renal failure, renal effects are considered secondary to extensive gastrointestinal injury. However, no quantitative data are available for lethal oral exposure in humans. A single ammonium gavage dose of $303 \mathrm{mg} / \mathrm{kg}$ as ammonium chloride is lethal in guinea pigs. Death results from pulmonary edema. However, cats, rabbits, and rats survived after a similar dose of ammonium $(337 \mathrm{mg} / \mathrm{kg}$ administered as ammonium chloride) (ATSDR, 1990).

Although mild hepatic effects and renal lesions reportedly occur in humans and in animals these effects are seen only at near-lethal oral doses (ATSDR, 1990); however, human quantitative data are not available. Again, these effects are considered secondary to chronic acidosis produced from the chloride ion rather than from the direct effect of ammonia on the kidney. Kidney enlargement, increased ammonia content, or increased urinary ammonia are reported in rats administered repeated oral ammonium doses of $433 \mathrm{mg} / \mathrm{kg}$-day (ATSDR, 1990). Renal tubular swelling, slight spontaneous nephritis, and acidosis were observed in rabbits exposed subchronically by gavage to 2377 or $14,722 \mathrm{mg}$ ammonium $/ \mathrm{kg}$-day as ammonium chloride for 36 and 234 days, respectively.

Ammonium salts have been used extensively in humans as acidifying agents when sodium chloride is medically contraindicated (Gilman et al., 1990). They are also sometimes used as expectorants. The acidifying action depends on the conversion by the liver of ammonium ions to urea with the generation of protons. Hepatic insufficiency contraindicates the use of ammonium salts. Of the ammonium salts, ammonium chloride, which has a fixed anion, is an acidifying salt; ammonium carbonate and ammonium bicarbonate, which have a labile anion, are not acidifying. Although kidney and liver disease have not been reported from such treatments, metabolic acidosis and related secondary electrolyte and bone alterations can be expected with prolonged oral exposure to ammonium salts (ATSDR, 1990). However, no dose-effect or dose-response data are available for humans following oral exposure to ammonia. Rats administered $977 \mathrm{mg}$ ammonium/kg-day as ammonium chloride in drinking water for 6 days had increased calcium serum levels. The increased serum calcium resulted from enhanced demineralization of bone in response to chronic acidosis. In another animal study, chronic treatment of rats with $991 \mathrm{mg}$ ammonium $/ \mathrm{kg}$ day as ammonium chloride in drinking water resulted in net bone resorption and reduced body weight. Subchronic oral exposure by gavage of dogs to $337 \mathrm{mg}$ ammonium/kg-day as ammonium chloride caused bone deformities and softening in exposed animals. Because these effects can be produced by prolonged oral exposure to any acidifying agent, they are not considered to be specific to ammonia exposure.

Other effects observed in animals following oral ingestion of ammonia include enlarged adrenal glands and decreased body weight or impaired weight gain 
(ATSDR, 1990). Enlarged adrenal glands were observed in rabbits that received $124 \mathrm{mg}$ ammonium/kg-day as ammonium hydroxide by gavage in water for 17 months. Increased water intake and reduced food intake was observed in weanling rats, and decreased body weight in adults, but not weanlings fed $79 \mathrm{mg}$ ammonium/kg-day in drinking water for 90 days as ammonium sulfamate. It has been suggested that the ammonium ion depresses the appetite. A no-observed-adverse-effect level (NOAEL) of $40 \mathrm{mg}$ ammonium $/ \mathrm{kg}$ day was determined in this study (ATSDR, 1990).

Individuals with severe hepatic disease and portal hypertension are sensitive to ammonium toxicity and often develop hepatic encephalopathy (Gilman et al., 1990). The condition is manifested by disturbance of consciousness and electroencephalograph abnormalities. The syndrome is frequently associated with elevated ammonia concentrations in the blood. Because it can be initiated by ingesting protein as well as by ingesting ammonium salts, it is considered in part representative of ammonia toxicity to the brain. Exposure levels responsible for these effects in humans are unknown. The occurrence of hyperammonemia in children and infants can result from defective enzymes of the urea cycle.

When drinking water is contaminated with ammonia, the unpleasant taste and odor of the water may make it unpalatable and consumption may be reduced. The taste threshold for water solutions of ammonia is about $35 \mathrm{mg} / \mathrm{L}$ (ATSDR, 1990). Figure 5.1 summarizes the health effects of oral exposure to ammonia as a function of dose.

The effects of ammonia water solutions on the eyes or skin are due to its alkaline properties, which result in serious delayed effects of alkali burns (Gilman et al., 1990; Casarett and Doull, 1991). Ammonia is especially toxic to the eye, leading to ulceration and perforation of the cornea and surrounding tissues. The severity of damage to the eye and skin is proportional to the ammonia concentration and duration of exposure. Ammonium hydroxide solutions applied to the skin in low concentrations produce redness; in high concentrations they cause severe skin burns. Because dermal exposure to ammonia also may lead to some inhalation exposure, it is difficult to determine the extent each route of exposure contributes to the toxicity observed after dermal contact with ammonia solutions.

\subsubsection{Antimony}

\section{Absorption}

Antimony can be absorbed both through inhalation and ingestion. At least 15 percent of a single oral dose of labeled antimony potassium tartrate given to mice is absorbed (i.e., recovered in (urine and tissues). However, absorption may be higher because gastrointestinal excretion starts immediately after the metal is taken up from the gut (Friberg et al., 1986). 


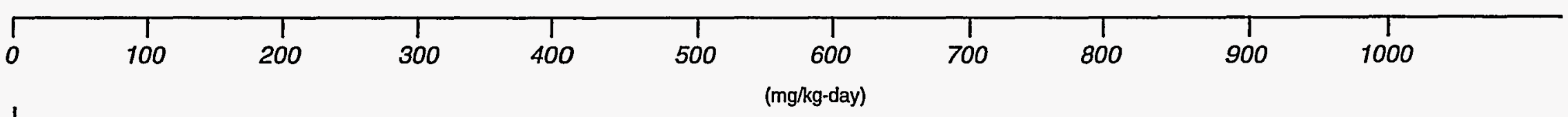

BACKGROUND INTAKE FROM WATER

- . .

NO OBSERVED EFFECT LEVEL FROM DRINKING WATER CONSUMPTION IN ANIMALS (RAT)

$\triangle$ AMOUNT PRODUCED IN THE GASTROINTESTINAL TRACT OF AN ADULT HUMAN

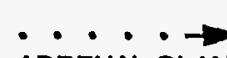

.......

ADRENAL GLAND ENLARGEMENT IN ANIMALS (RABBIT)

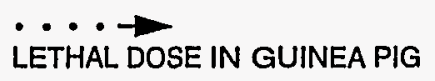

FIGURE 5.1 AMMONIA TOXICITY RANGES 


\section{Tissue accumulation and clearance}

Surface body scanning of people given intravenous injections of labeled antimony as sodium antimony dimercaptosuccinate revealed the highest amounts accumulate in the liver, thyroid, and heart. Forty-three days after the last injection, the liver still showed values of about one-sixth of the maximum, which was reached 1 day after the last injection (DHHS, 1992a).

Single intravenous or intramuscular injections to human volunteers produced higher 24-hour urinary excretion of pentavalent ( 80 percent) than of trivalent (25 percent) antimony compounds, a pattern similar to the one found in animals (Friberg et al., 1986).

A study on the elimination of a single, intravenously administered dose of labeled antimony potassium tartrate (trivalent) indicated that urinary excretion is about four times higher than fecal excretion (DHHS, 1992a). The initial excretion of antimony in humans is rapid. When pentavalent antimony compounds are given intravenously or intramuscularly, more than 90 percent of the dose will be found in the urine within 24 hours (DHHS, 1992a).

\section{Environmental sources of antimony}

Dietary antimony intake ranged from 0.25 to $1.25 \mathrm{mg}$ per day in a study of institutional diets for children in the United States (Friberg et al., 1986). Assuming an average body weight of $35 \mathrm{~kg}$, this intake is equivalent to 0.007 to $0.04 \mathrm{mg} / \mathrm{kg}$-day.

In freshwater fish, antimony concentrations on the order of 3 micrograms per kilogram $(\mu \mathrm{g} / \mathrm{kg})$ wet weight have been reported. Levels of 3 and $8 \mu \mathrm{g} / \mathrm{kg}$ have been found in milk and potato powder. Antimony is sometimes present in the binding coat between enamel and metal, especially in older cooking utensils, and can be dissolved by acidic food and drink when the enamel coating is worn. In soil, antimony usually ranges from 0.1 to $10 \mathrm{mg} / \mathrm{kg}$ dry weight (DW).

\section{Antimony toxicity}

The EPA oral RfD for antimony is $0.0004 \mathrm{mg} / \mathrm{kg}$-day. The RfD is based on a lifetime study of rats exposed to antimony trioxide in drinking water. The lowest dose producing adverse health effects (increased mortality in animals and altered blood chemistry) was $0.42 \mathrm{mg} / \mathrm{kg}$-day (EPA, 1994a).

After drinking lemonade containing 0.013 percent antimony, 70 people developed acute symptoms, including burning stomach pain, colic, nausea, and vomiting. It is estimated that $170-\mathrm{kg}$ adult consuming 300 milliliters $(\mathrm{mL})$ of lemonade would have received a dose of approximately $0.5 \mathrm{mg} / \mathrm{kg}$ (DHHS, 1992a). 
One study indicated that female workers exposed to antimony in a plant experienced a greater incidence of spontaneous abortions than did a control group of nonexposed working women. A high rate of premature deliveries among women who worked in antimony smelting and processing was also observed (Friberg et al., 1986). Reconstruction of dose and exposure conditions in the occupational setting is not available. Figure 5.2 summarizes the health effects of exposure to antimony as a function of dose.

\subsubsection{Arsenic}

\section{Absorption}

Arsenic is effectively absorbed through the gastrointestinal tract and via inhalation. Relative to gastrointestinal absorption, dermal absorption is negligible. In humans, approximately 80 percent of an ingested amount of dissolved inorganic trivalent (arsenite) or pentavalent arsenic (arsenate) is absorbed from the gastrointestinal tract (Pershagen and Vahter, 1979; Marafante and Vahter, 1987).

\section{Tissue accumulation and clearance}

After absorption by the gastrointestinal tract, arsenic is transported via the blood to most tissues. In humans as well as in most animal species, exposure to either arsenite or arsenate leads to an initial accumulation in the liver, kidneys, and lungs. Clearance from these tissues is very rapid, and a long-term retention of arsenic is seen in organs rich in sulfhydryl-containing proteins, such as the hair, skin, squamous epithelium of the upper gastrointestinal tract, epididymis, thyroid, lens, and skeleton (Lindgren et al., 1982). Specific target tissue depends on the arsenic form. Higher retention of arsenic occurs after exposure to trivalent arsenic than to the pentavalent form, and tissue distribution is altered (Webb, 1966; Casarett and Doull, 1991).

In humans and rats, inorganic arsenic passes through the placental barrier. It has also been demonstrated to enter both cow and human milk (Marcus and Rispin, 1988).

In the human body, where methylcobalamine acts as a major methyl group donor in the biotransformation process, inorganic arsenic converts to methylated compounds. The major site of arsenic methylation is known to be the liver (Marcus and Rispin, 1988). Trivalent arsenic is the substrate for methylation, and pentavalent arsenic must be reduced to trivalent arsenic before methylation can occur. Dimethylarsenic acid is a major metabolite found in animals and humans. Methylation results in a detoxification of inorganic arsenic labout 1 order of magnitude per methyl group) and increases the rate of arsenic excretion from the body.

The major route of excretion following human exposure to inorganic arsenic is via the kidneys (Friberg et al., 1986). Only a small amount is excreted in feces. 


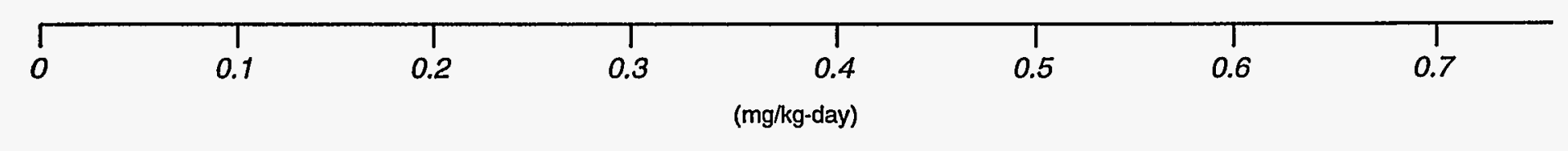

$$
\text { L_ }
$$

DIETARY INTAKE LEVELS

$\triangle$ ORAL RfD (0.0004 mg/kg-day)

\author{
MILD TOXICITY IN RATS \\ (DECREASED LONGEVITY, ALTERED BLOOD CHEMISTRY)
}

MILD TOXICITY IN HUMANS

(GASTROINTESTINAL DISTRESS AFTER ACUTE EXPOSURE)

FIGURE 5.2

ANTIMONY TOXICITY RANGES 
The rate of excretion in urine varies depending on the chemical form of arsenic, the duration of exposure, and the species exposed. In humans exposed to a single low dose of arsenite, about 35 percent was excreted in urine over a 48 hour period (Buchet et al., 1980; 1981). In the case of continuous human intake over a few days, 60 to 70 percent of the daily dose is excreted in urine (Buchet et al., 1981). Following exposure to arsenate, the limited human data available indicate a rate of excretion similar to that of arsenite. Other less important routes of elimination of inorganic arsenic include skin, hair, nails, and sweat.

After oral intake of radiolabeled pentavalent arsenic, 66 percent was excreted with a half time of 2.1 days, 30 percent with a half time of 9.5 days, and 3.7 percent with a half time of 38 days (Marcus and Rispin, 1988).

\section{Environmental sources of arsenic}

Arsenic is naturally ubiquitous in both inorganic and organic compounds. Water is the major means of arsenic transport under natural conditions. In oxygenated water, arsenic occurs in a pentavalent form; under reducing conditions, the trivalent form predominates.

As a result of arsenic's widespread occurrence, the general human population is exposed to it primarily through drinking water and food. Certain target groups are exposed to arsenic from industrial and agricultural uses. Medicinal use has also been a significant means of human exposure.

Drinking water usually contains a few micrograms of arsenic, predominantly as inorganic salts in the trivalent and pentavalent states (WHO, 1981; DHHS, 1993a). Surveys of drinking water in the United States have revealed that more than 99 percent of the public water supplies have arsenic levels below $0.05 \mathrm{mg} / \mathrm{L}$ (DHHS, 1993a) (equivalent to $0.001 \mathrm{mg} / \mathrm{kg}$-day for a $70-\mathrm{kg}$ adult drinking $2 \mathrm{~L}$ of water per day). However, concentrations of up to $1.1 \mathrm{mg} / \mathrm{L}$ in drinking water have been reported in Chile, Argentina, Taiwan, the United States, and the United Kingdom (WHO, 1981).

Seafood, meats, and grains contain the highest levels of arsenic. Wine and mineral waters can contain several hundred micrograms of arsenic per liter (Crecelius, 1977; WHO, 1981).

\section{Arsenic toxicity}

Exposure levels associated with acute arsenic toxicity vary with the valency form of the element. Trivalent arsenicals (arsenites) are generally more toxic than pentavalent (arsenates) (Morrison et al., 1989), and inorganic arsenic compounds are more toxic than organic (Shannon and Strayer, 1989). Based on geochemical models for the Rifle site, arsenic exists primarily in the pentavalent form in ground water (Table 3.6). For arsenic trioxide, the reported estimated acute oral lethal dose in humans ranges from 70 to $300 \mathrm{mg}(1$ to $4 \mathrm{mg} / \mathrm{kg}$ ) 
(EPA, 1984). Acute exposure to inorganic arsenic compounds may lead to severe inflammation of the gastrointestinal tract, encephalopathy, and acute renal failure after ingestion.

Increasing chronic doses of arsenic ingested orally progressively produce systemic effects, including arterial thickening in children and adults $(0.02 \mathrm{mg} / \mathrm{kg}$-day), neurological symptoms such as peripheral neuropathy $(0.04 \mathrm{mg} / \mathrm{kg}$-day), fibrosis of the liver $(0.05 \mathrm{mg} / \mathrm{kg}$-day), and cirrhosis of the liver (0.08 $\mathrm{mg} / \mathrm{kg}$-day) (DHHS, 1993a).

Chronic arsenic intoxications result from exposure to even small doses of arsenic over a long period of time. These intoxications frequently are caused by arsenic in drinking water and in food. Skin changes leading to skin cancer are commonly seen in populations exposed to high arsenic concentrations in drinking water. Endemic arsenic poisoning is seen in Cordoba, Argentina, where the arsenic concentration in drinking water ranges from 0.9 to $3.4 \mathrm{mg} / \mathrm{L}$ (equivalent to 0.026 to $0.097 \mathrm{mg} / \mathrm{kg}$-day). Certain areas in Taiwan also have high natural arsenic concentrations in drinking water that cause Blackfoot disease la peripheral extremity vascular disorder resulting in gangrene). A dose-response relationship between the incidence of Blackfoot disease and the duration of exposure to arsenic has been documented (Tseng, 1977; EPA, 1994a). The lowest arsenic dose associated with Blackfoot disease in continuously exposed individuals has been determined to be $0.014 \mathrm{mg} / \mathrm{kg}$-day (DHHS, 1993a).

Hyperpigmentation, hyperkeratosis, and skin cancer with prevalence of 7.1 percent, 18.4 percent, and 1.1 percent, respectively, were reported in Taiwanese studies of more than 40,000 people exposed to arsenic in drinking water at daily intakes ranging from 1.4 to $6.3 \mathrm{mg}$. However, hyperkeratosis and hyperpigmentation were observed at an exposure level as low as $0.014 \mathrm{mg} / \mathrm{kg}$-day (DHHS, 1993a).

Teratogenic effects of arsenic compounds administered intravenously or intraperitoneally at high doses have been demonstrated in laboratory animals only (Ferm, 1971; Hood, 1972; EPA, 1984). Teratogenic effects, also referred to as birth defects, are defined as effects resulting in structural or functional anomalies in live offspring.

Certain characteristics of exposed human populations may influence arsenic toxicity at high exposure levels. Genetic dispositions (rapid versus poor acetylators) and protein-deficient diet may decrease the methylation of arsenic. This can result in an increased deposition of the element in the target organs (e.g., lungs or skin).

The EPA has classified inorganic arsenic as a Group A (human) carcinogen (EPA, 1994a), based on the occurrence of increased lung cancer mortality (in populations exposed primarily via inhalation) and of increased skin cancer prevalence (in populations exposed by consuming drinking water containing high concentrations of arsenic). The current slope factor for oral exposure to arsenic 
is $1.8 \mathrm{mg} / \mathrm{kg}$-day (EPA, 1994a). Based on an oral unit risk of $5 \mathrm{E}-5$, this slope factor is under EPA review because recent data suggest arsenic ingestion may result in increased cancers in internal organs as well as skin cancers. Figure 5.3 summarizes the health effects of exposure to arsenic as a function of dose.

\subsubsection{Cadmium}

\section{Absorotion}

In humans, approximately 5 percent of cadmium ingested in water is absorbed (Friberg et al., 1986). The amount of cadmium absorbed from food sources is about half the amount absorbed from water. Gastrointestinal absorption likely depends on the physiologic status of an individual (age, body stores of iron) and on the presence and levels of divalent and trivalent cations and other dietary components ingested with cadmium. Young individuals appear to absorb more cadmium than older ones, and its absorption is increased in individuals with a diet high in fat and protein (Flanagan et al., 1978; DHHS, 1993b). Cadmium gastrointestinal absorption can decrease following exposure to calcium, chromium, magnesium, and zinc. Zinc and iron deficiencies may result in increased absorption and accumulation of cadmium.

Cadmium absorption in the gastrointestinal tract appears to occur in two phases: first, uptake from lumen into mucosa, and second, transfer in the blood (DHHS, 1993b). Cadmium uptake from lumen into mucosa may involve sequestering of cadmium by metallothionein, but any protective effect is overloaded at moderate doses. Cadmium absorption decreases at high concentrations. However, at doses high enough to damage gastrointestinal mucosa, fractional cadmium absorption increases (DHHS, 1993b).

\section{Tissue accumulation and clearance}

Humans with low-level and long-term exposure to cadmium show 50 percent of the body burden in the kidneys, 15 percent in the liver, and 20 percent in muscle (Kjellström, 1979). The kidney concentration will increase with continued exposure only to about age 50 , but the concentration in muscle will increase throughout life. Only 0.01 to 0.02 percent of the total body burden of cadmium is excreted daily, resulting in continuously increasing body burdens with prolonged exposure. The biological half-life of cadmium, or the time necessary to eliminate 50 percent of the cadmium in the body at a given time, is 10 to 30 years in humans (Nordberg et al., 1985).

\section{Environmental sources of cadmium}

The average cadmium content of nonpolluted drinking water $(0.003 \mathrm{mg} / \mathrm{L})$ results in about $0.00009 \mathrm{mg} / \mathrm{kg}$-day intake of cadmium estimated for a $70-\mathrm{kg}$ adult drinking $2 \mathrm{~L}$ of water per day. For a 22-kg child drinking $0.7 \mathrm{~L}$ of water per day, the estimated cadmium intake is $0.0001 \mathrm{mg} / \mathrm{kg}$-day (DHHS, 1993b). Cadmium occurs naturally with zinc and lead; therefore, it is often present as an 
impurity in products using these metals, such as solders and galvanized metals. These sources lead to contact with water supplies in water heaters and coolers, in some pipes, and in taps.

\section{Cadmium toxicity}

Short-term exposure to high cadmium concentrations $(15 \mathrm{mg} / \mathrm{L}$ in water) results in acute gastrointestinal effects, including abdominal cramps, diarrhea, and vomiting $(0.48 \mathrm{mg} / \mathrm{kg}$ for a $22-\mathrm{kg}$ child drinking $0.7 \mathrm{~L}$ of water per day). These gastrointestinal effects were not reported in any chronic environmental exposure.

In chronic oral human exposure, the kidney is the main target organ of cadmium toxicity (DHHS, 1993b). The primary toxic effect is reabsorption disturbance in the proximal tubules of the kidney. This effect is first observed by an increase of low molecular-weight proteins in the urine following a daily intake of $0.0075 \mathrm{mg} / \mathrm{kg}$-day. Progressive disruption of kidney function will lead to increased amino acids, glucose, phosphate, and protein in the urine. The critical concentration of cadmium in the renal cortex below which no adverse effect would be anticipated is estimated at about $200 \mu \mathrm{g}$ per gram fresh weight (Foulkes, 1990; EPA, 1994a). However, the apparently critical cadmium level in the kidney can vary significantly under different conditions of exposure; it can be affected by age, sex, and other factors influencing individual sensitivity to cadmium toxicity. The EPA-derived RfD is based on the critical cadmium concentration in the human renal cortex that is not associated with the critical effect manifested as significant proteinuria (EPA, 1994a). Because of already compromised kidney function, diabetics and the elderly can be more susceptible to cadmium toxicity (Buchet et al., 1990). Long-term exposures also can disturb calcium metabolism, leading to osteoporosis and osteomalacia. A combination of these two effects is referred to as Itai-itai disease and was seen in epidemic proportions in a cadmium-contaminated region in Japan in the 1950s (Friberg et al., 1986). Chronic dietary exposures of humans to cadmium produce no observable adverse effects at exposure levels of 0.001 to 0.002 $\mathrm{mg} / \mathrm{kg}$-day (DHHS, 1993b). Figure 5.4 summarizes the health effects of exposure to cadmium as a function of dose.

Cadmium has been classified as a probable human carcinogen by the EPA (EPA, 1994a) and the International Agency for Research on Cancer (IARC, 1987). Although chronic inhalation of cadmium oxide has been related to increased lung and prostate cancers in workers, evidence linking cadmium to cancer in humans is inconclusive at this time because of the presence of other known carcinogens in the workplace and small statistical differences in tumor incidences. No data, however, link oral cadmium ingestion to cancer in humans or animals (DHHS, 1993b). 


\begin{tabular}{|c|c|c|c|c|c|c|c|c|c|}
\hline 0 & 0.001 & 0.002 & 0.003 & 0.004 & $\begin{array}{l}0.005 \\
\text { (mg/kg-day) }\end{array}$ & 0.006 & 0.007 & 0.008 & 0.5 \\
\hline
\end{tabular}

I AVERAGE BACKGROUND INTAKE LEVEL FROM DRINKING WATER

$\triangle$ ORAL RID - DRINKING WATER (0.0005 mg/kg-day)

$$
\text { …....... - }
$$

NO OBSERVED EFFECTS FROM DRINKING WATER CONSUMPTION

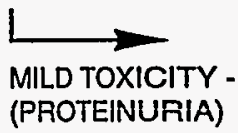

ACUTE TOXICITY $(0.48 \mathrm{mg} / \mathrm{kg}$; DOSE ESTIMATED FOR A

CHILD) 


\subsubsection{Chloride}

\section{Absorption, tissue accumulation, and clearance}

Chloride is rapidly and fully absorbed from the gastrointestinal tract. The chloride concentration in the human body is approximately $2000 \mathrm{mg} / \mathrm{kg}$ of fat-free body mass in newborns and $1920 \mathrm{mg} / \mathrm{kg}$ in adults (National Research Council, 1980). Chloride occurs in plasma at concentrations of 96 to 106 milliequivalents per liter (mEq/L) $(3400$ to $3800 \mathrm{mg} / \mathrm{L})$ and in a more concentrated form in cerebrospinal fluid and gastrointestinal secretions (National Research Council, 1989). Its concentration in most cells is low. The daily chloride turnover in adults (intake/output) ranges from 3000 to $8900 \mathrm{mg}$. Chloride is excreted mainly through urine, with appreciable amounts also excreted in feces, sweat, and tears.

\section{Environmental sources of chloride}

Dietary chloride comes almost entirely from sodium chloride (National Research Council, 1989). Much smaller amounts are supplied from potassium chloride. Thus, dietary sources of chloride essentially are the same as those for sodium, and processed foods are the major source of chloride. Rich sources of chloride are salt, cereals, breads, dried skim milk, teas, eggs, margarine, salted butter, bacon, ham, corned beef, canned meats, fish and vegetables, salted snack foods, and olives. Dietary chloride intake varies largely with salt intake. Estimates range from 2400 to $14,400 \mathrm{mg}$ chloride per day from sodium chloride (equivalent to 34 to $206 \mathrm{mg} / \mathrm{kg}$-day for a $70-\mathrm{kg}$ man).

Human breast milk contains $11 \mathrm{mEq} / \mathrm{L}$ of chloride (391 mg/L); a similar level has been recommended by the American Academy of Pediatrics for infant formulas (National Research Council, 1989).

Chloride is found in all natural water. Surface water contains only a few milligrams of chloride per liter, whereas streams in arid or semiarid regions contain several hundred milligrams per liter, especially in drained areas where chlorides occur in natural deposits or are concentrated from soils through evaporation. Contamination with sewage increases the chloride content of river water. Ground water usually contains larger quantities of chloride than surface water. Some public supply wells may contain $100 \mathrm{mg} / \mathrm{L}$ of chloride (about $3 \mathrm{mg} / \mathrm{kg}$-day, assuming $2 \mathrm{~L}$ of water are consumed per $70 \mathrm{~kg}$ of body weight) (National Research Council, 1980).

A typical chloride concentration in drinking water of about $21 \mathrm{mg} / \mathrm{L}$ would contribute $0.6 \mathrm{mg} / \mathrm{kg}$-day lassuming $2 \mathrm{~L}$ per day consumption rate and $70 \mathrm{~kg}$ body weight), or about 2 percent of the lower estimates of total chloride intake.

The recommended drinking water level for chloride is $250 \mathrm{mg} / \mathrm{L}$ (equivalent to $7 \mathrm{mg} / \mathrm{kg}$-day for a $70-\mathrm{kg}$ man consuming $2 \mathrm{~L}$ of water per day) (National Research Council, 1980). This amount of chloride in drinking water can cause 
an objectionably salty taste in water. The taste threshold for the chloride anion in water varies from 210 to $310 \mathrm{mg} / \mathrm{L}$.

\section{Chloride toxicity}

Chloride is an important inorganic anion in the extracellular fluid compartment. It is essential in maintaining fluid and electrolyte balance and is a necessary component of gastric juice.

Chloride loss from the body generally parallels sodium loss. Thus, conditions associated with sodium depletion (e.g., heavy, persistent sweating; chronic diarrhea or vomiting; trauma; renal disease) will also cause chloride loss, resulting in hypochloremic metabolic alkalosis.

Although the basic need for chloride is generally recognized, an RDA has not been determined. The estimated minimum requirement for healthy persons ranges from $180 \mathrm{mg}$ per day for infants to $750 \mathrm{mg}$ per day for adults (National Research Council, 1989).

The toxicity of salts containing the chloride ion depends primarily on the characteristic of the cation (National Research Council, 1980; 1989).

Large amounts of chloride intake may cause an increased chloride plasma concentration and a decreased bicarbonate plasma concentration, with an acidifying effect. This reaction results in hyperkalemic metabolic acidosis National Research Council, 1980). When metabolic acidosis develops, potassium leaves the cells arid is excreted by the kidney (Brater, 1992).

The only known dietary hyperchloremia results from water-deficiency dehydration. Sustained ingestion of high levels of chloride (as salt) is associated with hypertension in sensitive individuals and in animal models. Although the chloride level attributable to hypertension has not been determined, it may be estimated based on the level of sodium intake (from sodium chloride) that cause hypertension in approximately 15 percent of adults (Freis, 1976). This indirectly estimated amount of chloride presumably associated with hypertension in sensitive individuals would be in the range of 36 to $180 \mathrm{mg} / \mathrm{kg}$-day. Figure 5.5 shows the toxicity of chloride as a function of dose.

\subsubsection{Fluoride}

\section{Absorption}

Fluorides in water are absorbed primarily from the gastrointestinal tract, with the degr'ie of fluoride absorption depending on the solubility of a particular fluoride compound. 


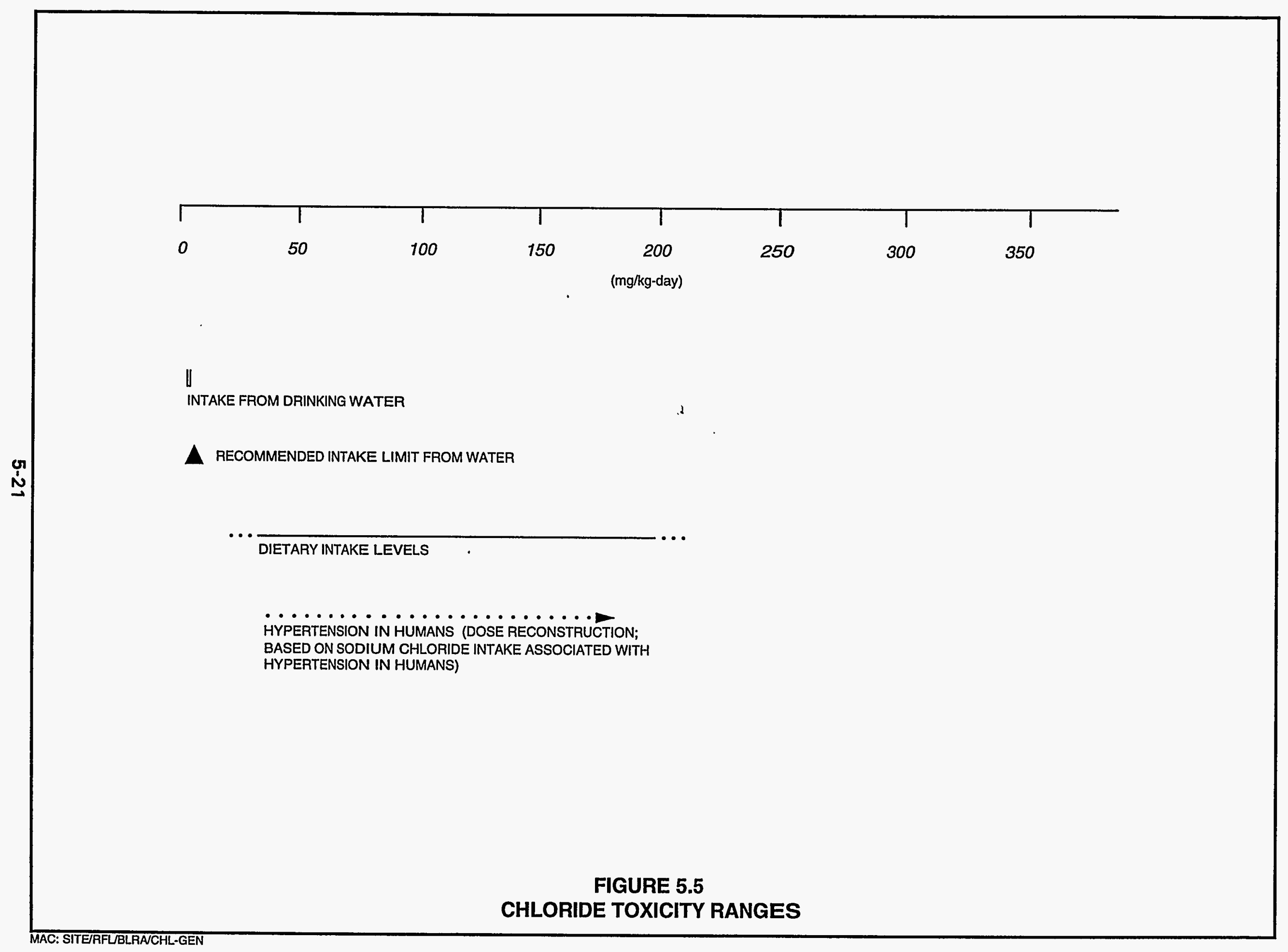


Fluoride is absorbed differently from food and drinking water. Fluoride absorption from water is estimated to be 100 percent, while protein-binding in food sources reduces dietary fluoride absorption. Fluoride absorption from milk or baby formula is determined to be only 72 and 65 percent, respectively, of that from water (National Research Council, 1989). Poorer absorption, from 37 to 54 percent, is reported for the fluorine in bone meal.

\section{Tissue accumulation and clearance}

Fluoride has been detected in all organs and tissues. Following gastrointestinal absorption, fluoride is distributed primarily to bones and is deposited in the skeleton and tooth enamel with lesser deposition in the thyroid, aorta, and kidney (Gilman et al., 1990; National Research Council, 1989). The degree of skeletal storage is related to intake and age. Storage in bone is thought to be a function of the turnover rate of skeletal components, with growing bone showing a greater fluoride deposition than mature organisms. Prolonged periods of time are required to mobilize fluoride from bone. The half time for turnover in the young adult skeleton is about 8 to 10 years (Maheshwari et al., 1981).

The major route of fluoride excretion is the kidney. However, fluoride also is excreted in small amounts through the sweat glands, breast milk, and the gastrointestinal tract. Under conditions of excessive sweating, the fraction of total fluoride excretion contributed by sweating can reach nearly one-half (Gilman et al., 1990). About 70 percent of the ingested fluoride is excreted in urine, and about 5 percent of that retained and absorbed is excreted in the feces (Maheshwari et al., 1981). About 90 percent of the fluoride filtered by the glomerulus is reabsorbed by the renal tubules (Gilman et al., 1990).

\section{Environmental sources of fluoride}

Drinking water and food are the primary sources of fluoride intake by humans. Drinking water, whether fluoridated or not, can contribute significantly to the total daily fluoride intake. In fluoridated areas, the contribution ranges from about 26 to 54 percent of the total intake (National Research Council, 1980). In unfluoridated areas, it ranges from about 14 to 48 percent.

Most public water supplies contain fluoride; most contain less than $1 \mathrm{mg} / \mathrm{L} 10.04$ $\mathrm{mg} / \mathrm{kg}$-day for a $25-\mathrm{kg}$ child ingesting $1 \mathrm{~L}$ of water per day or $0.03 \mathrm{mg} / \mathrm{kg}$-day for $70-\mathrm{kg}$ adult ingesting $2 \mathrm{~L}$ of water per day) (National Research Council, 1980). Fluoride concentrations in river water may be up to $6.5 \mathrm{mg} / \mathrm{L}$. The concentrations in lakes may be up to $1627 \mathrm{mg} / \mathrm{L}$. The average fluoride concentration of sea water is $1.2 \mathrm{mg} / \mathrm{h}$.

The richest dietary sources of iluoride are tea and marine fish consumed with their bones. In the United Kingdom, tea accounted for 72 percent $(1.3 \mathrm{mg})$ of the total adult daily intake of $1.8 \mathrm{mg}$ (National Research Council, 1989). The fluoride content of cow's milk is approximately $0.02 \mathrm{mg} / \mathrm{L}$. Mean reported values for human milk range from 0.005 to $0.25 \mathrm{mg} / \mathrm{h}$, depending on maternal 
intake (mothers were drinking water containing 0.2 and $1.7 \mathrm{mg} / \mathrm{L}$, respectively). Dietary fluoride intake up to $3.44 \mathrm{mg}$ per day $(0.05 \mathrm{mg} / \mathrm{kg}$-day for a $70-\mathrm{kg}$ adult) has been reported in some areas of the United States (National Research Council, 1980). An average fluoride dietary intake of $0.01 \mathrm{mg} / \mathrm{kg}$-day has been reported for both a $20-\mathrm{kg}$ child and a $70-\mathrm{kg}$ adult (EPA, 1994a).

Food processing substantially influences the fluoride content of foods. The fluoride content of many foods can increase severalfold by cooking in fluoridated water. Cooking in utensils treated with Teflon ${ }^{\otimes}$, a fluoride-containing polymer, can increase the fluoride content, whereas an aluminum surface can reduce it (National Research Council, 1989).

The estimated safe and adequate daily dietary intake (ESADDI) of fluoride for adults is 1.5 to $4.0 \mathrm{mg}$ per day (equivalent to 0.02 to $0.06 \mathrm{mg} / \mathrm{kg}$-day for a 70 $\mathrm{kg}$ man) (National Research Council, 1989). This range accounts for widely varying fluoride concentrations consumed in the United States and includes both food sources and drinking water. For younger age groups, the estimated maximum level of this intake is $2.5 \mathrm{mg}$ per day (equivalent to $0.1 \mathrm{mg} / \mathrm{kg}$-day for a 25-kg child). Ranges of 0.1 to $1 \mathrm{mg}$ per day during the first year of life (equivalent to 0.03 to $0.3 \mathrm{mg} / \mathrm{kg}$-day for a $4-\mathrm{kg}$ infant), and 0.5 to $1.5 \mathrm{mg}$ per day during the subsequent 2 years, are suggested as adequate and safe (National Research Council, 1989).

In view of fluoride's beneficial effects on dental health and its suggested safety at the ESADDI levels, the Food and Nutrition Board recommends fluoridation of public water supplies if natural fluoride levels are substantially below $0.7 \mathrm{mg} / \mathrm{L}$ (National Research Council, 1989).

\section{Fluoride toxicity}

Although at low doses fluoride can have beneficial effects of teeth and bone, at higher doses fluoride can be toxic. Children are particularly sensitive to dental fluorosis, the critical toxic effect of fluoride (EPA, 1994a). Fluoridation of water to a concentration of $1 \mathrm{mg} / \mathrm{L} 10.04 \mathrm{mg} / \mathrm{kg}$-day for a $25-\mathrm{kg}$ child, assuming ingestion of $1 \mathrm{~L}$ of water) is established as a safe and practical public health measure that results in a substantial reduction in the incidence of caries in permanent teeth (Gilman et al., 1990). Fluoride is also used to treat osteoporosis in larger doses than those used to prevent dental caries (Maheshwari et al., 1981). However, the optimal level of fluoride intake for osteoporosis therapy is not determined.

Fluoride inhibits several enzyme systems and diminishes tissue respiration and anaerobic glycolysis. It also binds $\mathrm{Ca}(+2)$, and inhibits the glycolytic utilization of glucose by erythocytes (Gilman et al., 1990). 
Acute fluoride poisoning usually results from accidental ingestion of insecticides or rodenticides containing fluoride salts (Gilman et al., 1990). The lethal dose of fluoride for a $70-\mathrm{kg}$ adult is approximately $32 \mathrm{mg} / \mathrm{kg}$.

In man, the major manifestations of chronic ingestion of excessive amounts of fluoride are dental fluorosis (mottled enamel) and osteosclerosis (crippling skeletal fluorosis) (Gilman et al., 1990; National Research Council, 1989; Casarett and Doull, 1991). L.ong-term exposure to excess fluoride causes increased osteoblastic activity (a process of bone development).

In very mild tooth mottling, the gross changes consist of small, opaque, paperwhite areas scattered irregularly over the tooth surface. In severe cases, discrete or confluent, deep brown- to black-stained pits give the tooth a corroded appearance. Mottled enamel or dental fluorosis is the result of a partial failure of the enamel-forming cells to elaborate properly and lay down enamel. It is a nonspecific response to several stimuli, one of which is excessive fluoride ingestion.

Because mottled enamel is a developmental disease, fluoride ingestion after tooth eruption has no effect on the disease (Gilman et al., 1990). Mottling is one of the first visible signs of excessive fluoride intake during childhood. Continuous use of water containing about 0.7 to $1.3 \mathrm{mg}$ fluoride per liter (equivalent to 0.03 to $0.05 \mathrm{mg} / \mathrm{kg}$-day for a $25-\mathrm{kg}$ child, assuming ingestion of 1 $L$ of water per day), depending on ambient temperature and diet, produces dental mottling and changes in tooth structure in 10 percent of children (National Research Council, 1980; Gilman et al., 1990). These effects were evaluated as the very mildest form of mottled enamel. At fluoride levels of 4 to $6 \mathrm{mg} / \mathrm{L} 10.16$ to $0.24 \mathrm{mg} / \mathrm{kg}$-day for a $25-\mathrm{kg}$ child, assuming ingestion of $1 \mathrm{~L}$ of water) the incidence reaches 100 percent, with marked increase in severity.

In osteosclerosis, as opposed to osteoporosis, bone density and calcification increases. Fluoride intoxication is thought to represent the replacement of hydroxyapatite by the denser fluorapatite. However, the mechanism of its development is unknown. The degree of skeletal involvement varies from changes that are barely detectable radiologically to marked thickening of the cortex of the long bones, numerous exostoses scattered throughout the skeleton, and calcification of ligaments, tendons, and muscle attachments to bone. In its severest form, osteosclerosis is a disabling disease and is designated as crippling fluorosis. It has been estimated that the development of crippling skeletal fluorosis in humans requires daily ingestion of 20 to $80 \mathrm{mg}$ fluoride $(0.29$ to $1.1 \mathrm{mg} / \mathrm{kg}$-day for a $70-\mathrm{kg}$ adult) over a 10 - to 20-year period (National Research Council, 1980; 1989; EPA, 1994a). Although the NOAEL for crippling skeletal fluorosis in humans is unknown, a safe total fluoride exposure level (from food and drinking water) for adults is suggested to be $0.12 \mathrm{mg} / \mathrm{kg}$-day. This exposure level corresponds to the consumption of $2 \mathrm{~L}$ of water per day containing $4 \mathrm{mg}$ fluoride per liter by a $70-\mathrm{kg}$ adult and the ingestion of $0.01 \mathrm{mg}$ fluoride per day in the diet. 
The EPA oral RfD of $0.06 \mathrm{mg} / \mathrm{kg}$-day was developed based on the NOAEL of 1 mg fluoride per liter of drinking water, determined in children from 12 to 14 years old, and the assumption that a $20-\mathrm{kg}$ child consumes $0.01 \mathrm{mg}$ fluoride $/ \mathrm{kg}$ day in the diet (EPA, 1994a). Figure 5.6 shows the health effects of fluoride as a function of dose.

\subsubsection{Iron}

\section{Absorption}

The percentage of dietary iron that is absorbed ranges from 2 percent in individuals with diseases of the gastrointestinal tract to 35 percent in rapidly growing, healthy children (Casarett and Doull, 1991; Whitney et al., 1990). Normally, 10 to 15 percent of dietary iron is absorbed, but this percentage varies to compensate for the level of iron in the body (Friberg et al., 1986). For example, patients with iron-deficiency anemia can absorb as much as 60 percent of an oral dose of iron (Josephs, 1958).

Iron absorption also is influenced by factors such as the source and chemical form of the ingested iron, other substances in the diet, and the condition of the gastrointestinal tract (Friberg et al., 1986). Very little is known about the absorption of iron from water and about the chemical species of iron in drinking water from the tap. Although the amount of ferric ion $\left(\mathrm{Fe}^{3+}\right)$, ferrous ion $\left(\mathrm{Fe}^{2+}\right)$ and organic complexes of iron in water that are absorbed by humans is unknown, it is clear that reducing agents such as ascorbic acid increase the absorption of iron in food (National Research Council, 1980). Ferrous ion appears to have better availability than does ferric ion. Iron from animal sources is absorbed by humans more effectively than iron from vegetables and grains. Soluble forms of iron such as iron sulfate are taken up more readily than insoluble forms such as iron oxide. In the ground water at the Rifle sites, iron is present predominantly in the form of ferrous ion and also as iron sulfate (Table 3.6). Therefore, iron forms present in the ground water may be absorbed readily.

The presence of other metals also affects iron absorption. Absorption is decreased in the presence of high levels of phosphate, cobalt, copper, and zinc (Friberg et al., 1986). Excess manganese can significantly decrease iron absorption by impairing hemoglobin regeneration in the blood (National Research Council, 1980)

\section{Tissue accumulation and clearance}

Iron absorption from the gastrointestinal tract occurs in two steps: first, ferrous ions from the intestinal lumen are absorbed into the mucosal cells; second, they are transferred from the mucosal cells to plasma, where they are bound to transferrin for transfer to storage sites. As ferrous ion is released into plasma, it is oxidized by oxygen in the presence of ferroxidase 1 (Casarett and Doull, 1991). 


\begin{tabular}{|c|c|c|c|c|c|c|c|c|c|}
\hline 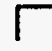 & $T$ & $T$ & $T$ & 1 & 1 & 1 & 1 & 1 & 1 \\
\hline 0 & 0.1 & 0.2 & 0.3 & 0.4 & 0.5 & 0.6 & 0.7 & 0.8 & 0.9 \\
\hline
\end{tabular}

I AVERAGE DIETARY INTAKE LEVEL FROM FOOD

INTAKE LEVELS FROM DRINKING WATER

L...

NO OBSERVABLE EFFECT LEVEL FOR DENTAL FLUOROSIS

- - - ...

DENTAL MOTTLING AND CHANGES IN TOOTH STRUCTURE IN CHILDREN - OBJECTIONABLE DENTAL FLUOROSIS

ORAL REFERENCE DOSE (FOOD AND DRINKING WATER) $(0.06 \mathrm{mg} / \mathrm{kg}$-day)

INCREASING DENTAL MOTTLING WITH INCREASING INTAKE IN CHILDREN

NO OBSERVABLE EFFECT LEVEL FOR SKELETAL FLUOROSIS IN ADULTS

CRIPPLING SKELETAL FLUOROSIS IN ADULTS (0.29-1.1 mg/kg-day)

FIGURE 5.6

FLUORIDE TOXICITY RANGES 
Normally, the adult human body contains about 3 to 5 grams of iron. Two-thirds of this amount is found in the blood, bound to hemoglobin. Less than 10 percent of the body iron is found in myoglobin and iron-requiring enzymes. About 20 to 30 percent of the remaining iron in the body pool is bound to iron-storage proteins in the liver, bone marrow, and spleen (Friberg et al., 1986).

Under normal conditions, the total elimination of iron from the body is limited to 0.6 to $1.0 \mathrm{mg}$ per day, or roughly 0.01 percent of the body stores. Of the iron absorbed from the gut, about 0.2 to $0.5 \mathrm{mg}$ of elemental iron per day is eliminated through the feces and about 0.1 to $0.3 \mathrm{mg}$ per day is eliminated in urine. The remainder is eliminated through normal dermal losses in sweat, hair, and nails. Based on these rates of elimination, the biological half-life of iron in the body is estimated at 10 to 20 years (Friberg et al., 1986).

\section{Environmental sources of iron}

The iron concentrations of liver, kidney, beef, ham, egg yolk, and soybeans are in the order of 30 to $150 \mathrm{mg} / \mathrm{kg}$ fresh weight. Grains and fruits are low in iron, usually ranging from 1 to $20 \mathrm{mg} / \mathrm{kg}$. The iron concentration of both human and cow's milk is about $0.5 \mathrm{mg} / \mathrm{L}$ (Friberg et al., 1986)

The average daily intake of iron ranges from 9 to $35 \mathrm{mg}$ per day 10.1 to $0.5 \mathrm{mg} / \mathrm{kg}$-day) (Friberg et al., 1986). Approximately 35 percent of dietary iron comes from meat, fish, and eggs, while 50 percent is supplied by cereals, root vegetables, and other foods of plant origin (National Research Council, 1980).

Iron concentrations in water vary greatly. In the United States, the iron concentrations of freshwater and public water supplies range from 0.01 to $1.0 \mathrm{mg} / \mathrm{L}$ (Friberg et al., 1986). Assuming a $2 \mathrm{~L}$ per day consumption of water by a $70-\mathrm{kg}$ (body weight) adult, this range would result in an intake of 0.0003 to $0.03 \mathrm{mg} / \mathrm{kg}$-day of iron from drinking water.

The RDA for iron is $10 \mathrm{mg}$ (approximately $0.14 \mathrm{mg} / \mathrm{kg}$-day) for adult males and $18 \mathrm{mg}$ (approximately $0.25 \mathrm{mg} / \mathrm{kg}$-day) for females of reproductive age (National Research Council, 1980).

\section{Iron toxicity}

Iron intoxication is most frequent in children aged of 1 to 3 years who ingest adult iron supplements in the form of ferrous sulfate tablets with candy-like coatings. Severe poisoning in children may occur following ingestion of more than 0.5 gram (approximately $22 \mathrm{mg} / \mathrm{kg}$ ) of iron, about 2.5 grams (approximately $110 \mathrm{mg} / \mathrm{kg}$ ) as ferrous sulfare. This acute iron poisoning has occurred in children who ingested as few as 6 iron tablets (Whitney et al., 1990). Excessively high iron intake damages the lining of the gastrointestinal tract, producing vomiting as the first symptom. Bleeding of the damaged gastrointestinal tissue frequently results in blood in the vomit and 
black stools (Casarett and Doull, 1991). Shock and metabolic acidosis can develop. If the patient survives the initial crisis, liver damage with hepatitis and coagulation defects often occur within a few days. Renal failure and cirrhosis of the liver may occur as delayed effects (Friberg et al., 1986).

Long-term intake of iron in a form that is readily absorbed and in doses exceeding 50 to $100 \mathrm{mg}$ of iron per day 10.7 to $1.4 \mathrm{mg} / \mathrm{kg}$-day for a $70-\mathrm{kg}$ adult male) (Friberg et al., 1986) results in an increased body burden of iron because iron is removed from the body at a much slower rate than it is absorbed. As the body burden of iron increases; to between 20 and 40 grams (roughly 10 times the normal level), production of the iron-binding protein hemosiderin increases and results in a condition known as hemochromatosis. This condition starts with increased pigmentation of the skin and higher concentrations of iron in the liver, pancreas, endocrine organs, and heart. This increased tissue iron can produce cirrhosis of the liver, disturbances in endocrine and cardiac function, and diabetes mellitus (Casarett and Doull, 1991).

Chronic iron toxicity in adults can be caused by genetic factors, excess dietary iron, excessive ingestion of iron-containing tonics or medicines, or multiple blood transfusions. The pathologic consequences of iron overload are similar regardless of basic cause (Casarett and Doull, 1991).

Figure 5.7 summarizes the health effects from exposure to iron as a function of dose.

\subsubsection{Lead}

\section{Absorption}

About 10 percent of ingested lead is absorbed in the gastrointestinal tract, although in some adults up to 40 percent may be absorbed. Higher fractions of lead may be absorbed by infants, children, fasting adults, and people with certain nutritional deficiencies. Up to 53 percent absorption was reported in a group of eight children ranging in age from 3 months to 8 years (WHO, 1977).

Animal studies show that certain dietary factors (e.g., milk consumption; fasting; low potassium, calcium, and vitamin D; and iron deficiency) may enhance lead absorption. A low-protein diet may increase susceptibility to lead toxicity (DHHS, 1993c). Phosphate may decrease absorption of lead (Heard and Chamberlain, 1982).

The chemical form of lead affects the readiness with which lead is absorbed from the gastrointestinal tract. Highly soluble compounds are more readily absorbed. 

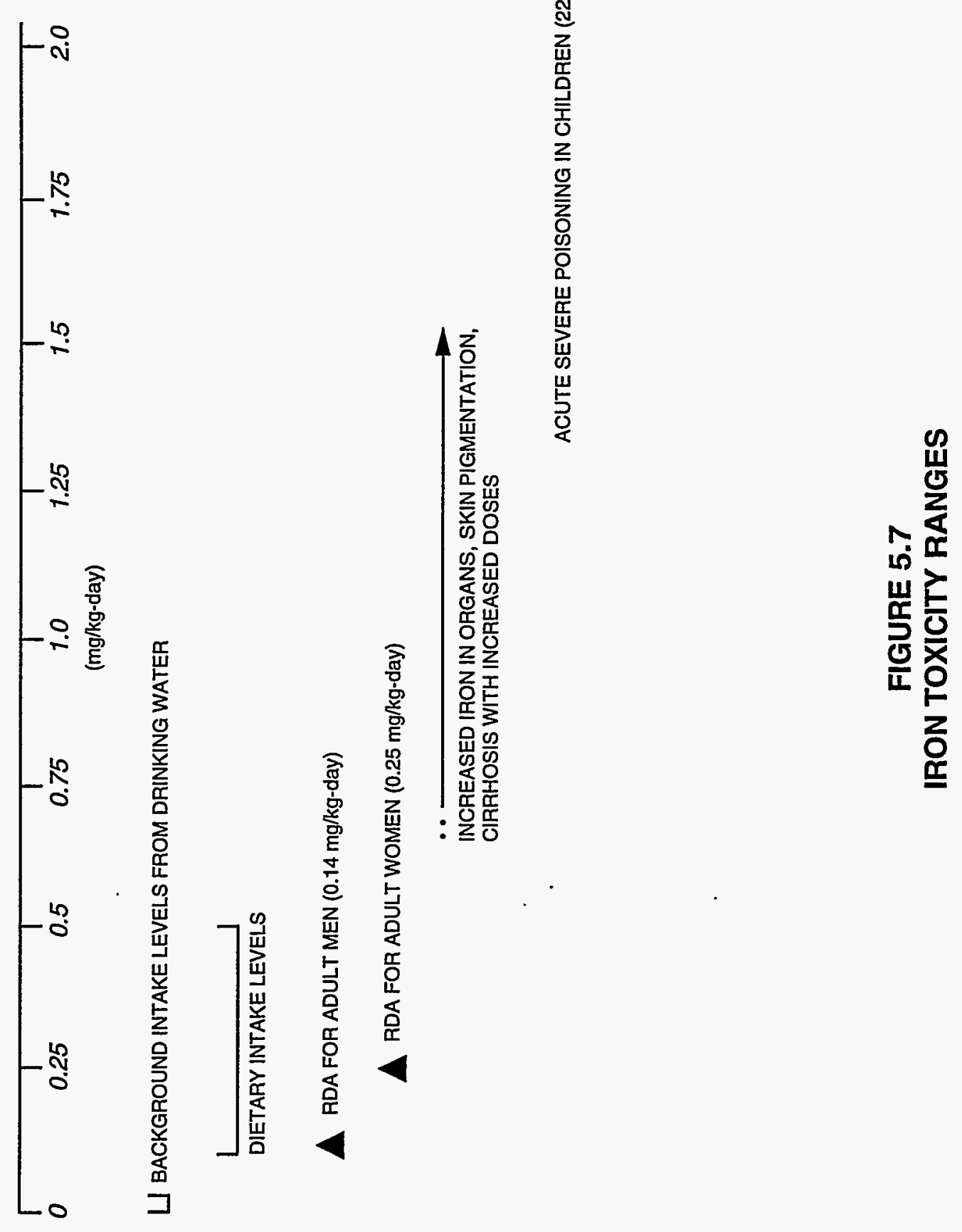


\section{Tissue accumulation and clezrance}

Absorbed lead is transported by the blood and initially distributed to various organs and tissues. It is then gradually redistributed to blood and soft tissue from the bone. In human subjects with low-level exposure, about 90 percent of the total body burden is found in bone (DHHS, 1993c). Lead in a skeleton has a half-life of about 20 years, and the amount of lead in this compartment increases throughout life. The second, smaller compartment (blood, soft tissue, and rapidly exchangeable bone fraction) has a half-life of about 20 days. Some studies indicate that the mean retention of lead in blood and soft tissue is about 3 weeks to 1 month and in bone about 5 years (DHHS, 1993c). Lead accumulates in the brain and can be retained for a long time after the external exposure has ceased and the concentration of lead in the blood has declined.

About 90 percent of ingested lead is eliminated unabsorbed in feces. Absorbed lead is excreted mainly in urine (about 76 percent) and through gastrointestinal secretion (about 16 percent); small amounts (less than 8 percent) are excreted in milk, sweat, hair, and nails (DHHS, 1993c). Glomerular filtration is the primary mechanism of lead urinary excretion.

Lead levels in blood are the most widely used biological indicator of internal lead exposure. A blood lead level greater than 10 micrograrns $(\mu \mathrm{g}) / 100 \mathrm{~mL}$ indicates an excessive lead exposure (DHHS, 1993c).

Lead readily crosses the placental barrier; therefore, exposing women to lead during pregnancy results in fetal uptake.

\section{Environmental sources of leart}

The chemistry of lead in water is highly complex because it can be found in many forms. It tends to form compounds of low solubility with the major anions of natural water. In the natural environment, the divalent form $\left(\mathrm{Pb}^{+2}\right)$ is the stable ionic species of lead. Natural compounds of lead are usually not mobile in ground water or surface water, because lead tends to combine with carbonate or sulfate ions to form insoluble compounds under oxidizing conditions and extremely insoluble lead sulfide under reducing conditions (DHHS, 1993c). Lead is more mobile in acidic waters, and precipitation occurs more rapidly in alkaline waters.

Lead has been monitored in surface water, sediments and soils, ground water, and drinking water throughout the world. The lead concentration of surface water varies greatly depending upon pollution sources, sediment lead content, and system rharacteristics (e.g., pH, temperature). Lead levels in surface waters throughout the United States typically range from 5 to 30 microgram per liter $(\mu \mathrm{g} / \mathrm{L})$, althnugh levels as high as $890 \mu \mathrm{g} / \mathrm{L}$ have been found (DHHS, 1993c). Sediments contain considerably higher levels of lead than corresponding surface water. The average lead content of river sediments is 
about $20 \mathrm{mg} / \mathrm{kg}$. The natural concentration of lead in soils ranges from 2 to $200 \mathrm{mg} / \mathrm{kg}$, with mean values about $16 \mathrm{mg} / \mathrm{kg}$, depending upon location (NAS, 1972). The typical lead concentration in ground water ranges from 1 to $100 \mu \mathrm{g} / \mathrm{L}$. The mean concentration of lead in rainwater at 32 United States monitoring stations was $34 \mu \mathrm{g} / \mathrm{L}$ and the maximum value observed was $300 \mu \mathrm{g} / \mathrm{L}$. In areas with heavy traffic, lead in rain may exceed $100 \mu \mathrm{g} / \mathrm{L}$ and even reach $500 \mu \mathrm{g} / \mathrm{L}$. In 1990, lead intake from U.S. drinking water was calculated at $12 \mu \mathrm{g}$ per day for a 6 -year old child (equivalent to $0.0012 \mathrm{mg} / \mathrm{kg}$ day) (DHHS, 1993c).

The primary source of lead for the general population is food; for occupational groups, it is inhalation. Important sources of exposure for children in some countries are lead paint, soil, and dust.

The estimated daily dietary intake of lead ranges from 5 to $11 \mu \mathrm{g}$ per day for all age groups combined (equivalent to 0.0005 to $0.0011 \mathrm{mg} / \mathrm{kg}$-day for a $10-\mathrm{kg}$ child) (DHHS, 1993c).

\section{Lead toxicity}

Although the biological effects of lead in humans are fairly well defined, the precise exposure or doses associated with the effects are not well known. Dose-response data are available in terms of blood lead levels, rather than external exposure levels.

Lead and its compounds are cumulative toxicants. Lead may cause both acute and chronic effects, which usually result from its accumulation in the body over a period of time. The major effects are related to four organ systems: the hematopoietic, nervous, gastrointestinal, and renal systems.

Young children are inherently more susceptible to the effects of lead for the following reasons:

- Incomplete development of the blood-brain barrier at birth, increasing the risk of lead entering the central nervous system.

- Their greater lead intake in the gastrointestinal tract on a body-weight basis compared with adults.

- The greater absorption and retention rates of lead in children.

- A greater prevalence of nutrient deficiency in children, which can affect gastrointestinal lead absorption.

- Differences in the efficiency of lead sequestration in bone. 
Acute toxicity - The most common form of acute lead poisoning is gastrointestinal colic. Acute signs and symptoms of lead poisoning may result both from short-term massive exposure and from long-term lead intake. After an initial stage of anorexia, symptoms of dyspepsia and constipation develop; there is an attack of colic characterized by diffuse paroxysmal abdominal pain. Other signs are pale skin, slow pulse, and increased blood pressure. These signs and symptoms reflect the spasmodic contraction of smooth muscle, probably related to vagal irritation.

Acute lead encephalopathy in adults is rare, but numerous cases have been observed in children (Casarett and Doull, 1991; DHHS, 1993c; NAS, 1972). Severe forms of encephalopathy develop suddenly with the onset of seizures and delirium, often associated with papilledema, and may result in coma and/or cardiorespiratory arrest. Prodromal manifestations occur rarely, but some children may develop anemia and mild colic prior to the onset of the acute encephalopathy syndrome (which includes vomiting, apathy, drowsiness, stupor, ataxia, hyperactivity, and other neurological signs and symptoms). Lead concentrations in blood associated with acute encephalopathy ranged from about 80 to $100 \mu \mathrm{g} / 100 \mathrm{~mL}$ (DHHS, 1993c). In adults, symptoms of encephalopathy were seen at blood lead levels of $50 \mu \mathrm{g} / 100 \mathrm{~mL}$, following short-term exposures to lead.

Chronic toxicity - Chronic exposure to lead may affect the hematopoietic system, nervous system, gastrointestinal tract, kidney, liver, cardiovascular system, and endocrine organs. No visible thresholds have been demonstrated for the most sensitive effects of lead exposure in humans (i.e., heme synthesis, erythropoiesis, and neurobehavioral toxicity).

Anemia is a common sign among workers exposed to lead mainly by inhalation. Lead-induced anemia is micro- or normocytic and hypochromic, being caused by a combined effect of the inhibition of hemoglobin synthesis and shortened lifespan of circulating erythrocytes. No safe blood lead level has been demonstrated for hematological effects in children. Studies on adults indicate that blood lead levels as low as $3 \mu \mathrm{g} / 100 \mathrm{~mL}$ may produce hematological effects (e.g., decreased $\delta$-aminolevulinic acid dehydratase [ALAD] activity) (DHHS, 1993c). A lead oral intake level as low as $0.01 \mathrm{mg} / \mathrm{kg}$-day produced hematological effects in humans and laboratory animals (rats and monkeys) (DHHS, 1993c). The effectsi were manifested in decreased activities of certain enzymes (e.g., ALAD), increased levels of porphyrin and protoporphyrin IX in red blood cells, and impaired herne synthesis (DHHS, 1993c). When the lead blood level is about 70 to $80 \mu \mathrm{g} / 100 \mathrm{~mL}$ or more, anemia may develop in some individuals (Casarett and Doull, 1991; DHHS, 1993c). However, good nutrition may prevent recognizable lead anemia.

Increased lead absorption may affect both the central nervous system and the peripheral nervous system. Effects on the central nervous system manifest as encephalopathy. The severity of encephalopathy depends on a combination of 
factors, including intensity and duration of exposure and age. Milder central nervous system symptoms include mental deterioration, hyperkinetic or aggressive behavior, sleeping difficulties, and vomiting. No-effect lead blood levels for chronic encephalopathy were determined for children at about 50 to $60 \mu \mathrm{g} / 100 \mathrm{~mL}$ and for adults at about $80 \mu \mathrm{g} / 100 \mathrm{~mL}$ (DHHS, 1993c). Changes in neurobehavioral function, including slightly decreased performance on intelligence quotient tests, were observed in children at blood lead levels as low as $6 \mu \mathrm{g} / 100 \mathrm{~mL}$, and blood lead levels at 10 to $15 \mu \mathrm{g} / 100 \mathrm{~mL}$ were associated with impaired mental development (DHHS, 1993c). Neurobehavioral testing has revealed an effect in adults at blood lead levels of 40 to $80 \mu \mathrm{g} / 100 \mathrm{~mL}$.

Chronic as well as short-term exposures to lead resulting in blood lead levels of 40 to $80 \mu \mathrm{g} / 100 \mathrm{~mL}$ produced neurological signs and symptoms in adults, including malaise, forgetfulness, irritability, lethargy, headache, fatigue, impotence, decreased libido, dizziness, weakness, and paresthesia. In children, neurological signs and symptoms other than encephalopathy were observed at blood lead levels of $60 \mu \mathrm{g} / 100 \mathrm{~mL}$ (DHHS, 1993c).

Neurobehavioral signs and symptoms appeared at a lead oral intake level of $0.01 \mathrm{mg} / \mathrm{kg}$-day in test animals (rats and monkeys administered lead acetate in drinking water) (DHHS, 1993c). These effects included disruption of conditioned responses and changes in motor activity. Serious neurobehavioral changes resulted from orat lead intake of $0.05 \mathrm{mg} / \mathrm{kg}$-day. Later adverse health effects included impairment in delayed changes of behavioral tasks, impairment of nonspatial discrimination, and impairment of operant learning. At higher lead intake levels, decreased muscle tonus and visual attentiveness were observed in these species (DHHS, 1993c). Reports on peripheral lead neuropathy are rare and are primarily from excessive occupational exposure. Peripheral neuropathy is characterized by motor nerve dysfunction. Sensory nerves are less sensitive to lead than motor nerves. Signs of peripheral lead neuropathy were observed in children with blood lead levels of $20 \mu \mathrm{g} / 100 \mathrm{~mL}$ and at $30 \mu \mathrm{g} / 100 \mathrm{~mL}$ in adults (DHHS, 1993c).

Quantitative information on lead hepatotoxicity in humans is lacking. Hepatotoxicity in rats resulted from exposure to lead in drinking water las lead acetate) at intake levels as low as 0.01 to $0.05 \mathrm{mg} / \mathrm{kg}$-day (DHHS, 1993c). The effects included decreased glycogen, ribonucleic acid, and sulfhydryl groups, as well as alterations in activities of oxidizing enzymes and increased liver weight.

Long-term exposure to lead may give rise to the development of irreversible functional and morphological renal changes. These changes include intense interstitial fibrosis, tubular atrophy, and dilatation. The glomeruli may be involved at a relatively late stage (Casarett and Doull, 1991). Prolonged exposure to lead associated with lead blood levels above $70 \mu \mathrm{g} / 100 \mathrm{~mL}$ may result in chronic irreversible nephropathy (DHHS, 1993c), but little is known about the dose-effect or dose-response relationship of the nephrotoxicity of 
inorganic lead. However, blood lead levels at 18 to $26 \mu \mathrm{g} / 100 \mathrm{~mL}$ resulted in renal impairment with gout or hypertension.

Increased blood pressure is associated with lead blood concentrations possibly as low as $7 \mu \mathrm{g} / 100 \mathrm{~mL}$ (EPA, 1986; DHHS, 1993c). It appears that this relationship is particularly significant for middle-aged white males laged 40 to 59). In laboratory animals (rats fed lead acetate in drinking water for up to 8 months), the cardiovascular effects manifested as increased systolic blood pressure were observed at lead intake levels of $0.01 \mathrm{mg} / \mathrm{kg}$-day (DHHS, 1993c).

Prenatal exposure to lead may be related to postnatal mental retardation, impaired postnatal neurobehavioral development, premature birth, and reduced birth weight (DHHS, 1993c).

Exposure to inorganic lead has been associated with cancers (renal tumors) in laboratory animals, but lead carcinogenicity in humans has not been demonstrated. Because there is sufficient evidence of lead carcinogenicity in animals and because human data are insufficient, it has been classified as a probable human carcinogen (EPA, 1994a; IARC, 1987).

Because some of the adverse health effects from oral lead exposures, particularly hematological changes and changes in children's neurobehavioral development, may occur at intake levels so low they are essentially without threshold, the EPA considers it inappropriate to develop an oral RfD for inorganic lead (EPA, 1994a).

Figure $\mathbf{5 . 8}$ summarizes the health effects of lead as a function of dose.

\subsubsection{Manganese}

\section{Absorption}

Following ingestion, manganese absorption is homeostatically controlled: the absorption rate depends on both the amount ingested and the existing manganese levels in tissue. Adults absorb approximately 3 to 4 percent of dietary manganese (Friberg et al., 1986). Manganese can be absorbed following exposure by inhalation, ingestion, and dermal contact. In humans, available data indicate that only 3 percent of an ingested dose of manganese chloride is absorbed (Mena et al., 1969). Manganese in water appears to be more efficiently absorbed than manganese in foodstuff (EPA, 1994a). The absorption rate is influenced by iron and other metals. In states of iron deficiency, manganese is actively absorbed from the intestine. Individuals with anemia can absorb more than twice the percentage of an ingested dose. However, in states of excess iron, manganese absorption is by diffusion only (Friberg et al., 1986). High levels of dietary calcium and phosphorus are shown to increase the requirements for manganese in several species (Lönnerdal et al., 1987). 


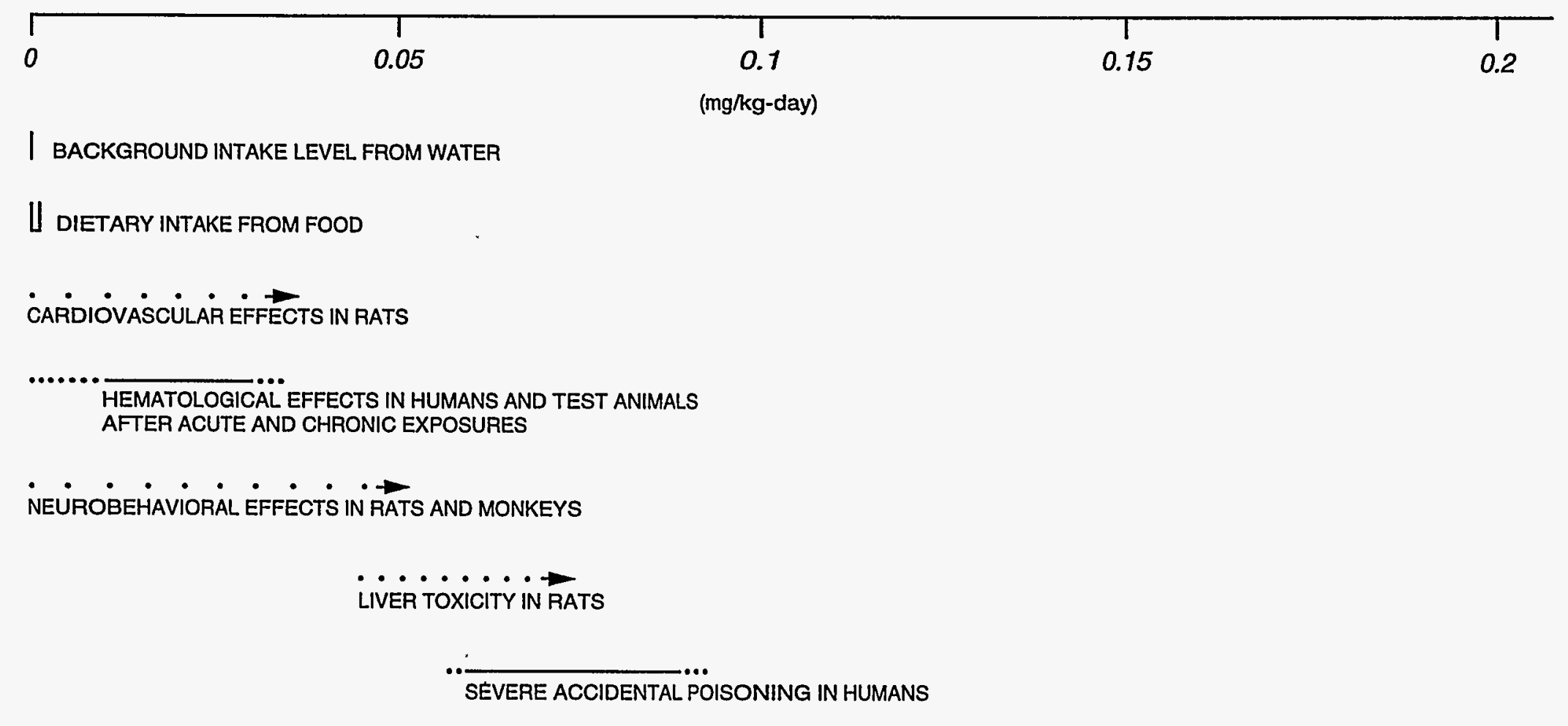

FIGURE 5.8

LEAD TOXICITY RANGES 


\section{Tissue accumulation and clearance}

Manganese is widely distributed throughout the body. The highest concentrations are found in the liver and kidney and, to a lesser extent, the hair. The biological half time in humans is 2 to 5 weeks, depending on body stores. Manganese readily crosses the blood-brain barrier and is more slowly cleared from the brain than from other tissue (Casarett and Doull, 1991). Normal concentrations in the brain are low, but the half time in the brain is longer and the metal may accumulate in the brain with excessive absorption (National Research Council, 1973).

Absorbed manganese is rapicly eliminated from the blood and concentrates in mitochondria. Initial concentrations are greatest in the liver. Manganese penetrates the placental barrier in all species and is more uniformly distributed throughout the fetus than in adults. It is secreted into milk.

Absorbed manganese is almost totally secreted in bile and reabsorbed from the intestine as needed to maintain body levels. At excessive exposure levels, other gastrointestinal routes may participate. Excess manganese is eliminated in the feces; urinary excretion is negligible (Casarett and Doull, 1991; Friberg et al., 1986).

\section{Environmental sources of manganese}

On the whole, food constitutes the major source of manganese intake for humans. The highest manganese concentrations are found in plants, especially wheat and rice. Drinking water generally contains less than $0.1 \mathrm{mg} / \mathrm{L}$. Manganese levels in soil range from 1 to $7000 \mathrm{mg} / \mathrm{kg}$, with an average of 600 to $900 \mathrm{mg} / \mathrm{kg}$. Mining and natural geological background variations contribute to this variability. Manganese bioaccumulates in marine mollusks up to $12,000-$ fold, and there is evidence for toxic effects in plants (phytotoxicity) and plant bioaccumulation. The Illinois Institute for Environmental Quality has recommended a criterion of 1 to $2 \mathrm{mg} / \mathrm{kg}$ for manganese in soil and $200 \mathrm{mg} / \mathrm{kg}$ in plants (Friberg et al., 1986).

Variations in manganese intake can be explained to a large extent by differences in nutritional habits. In populations using cereals and rice as main food sources, the intake will be higher than in areas where meat and dairy products are a larger part of the diet. The average daily intake has been estimated to be between 2.0 to $8.8 \mathrm{mg}$ per day $(0.03$ to $0.13 \mathrm{mg} / \mathrm{kg}$-day) (EPA, 1994a), but intakes as high as $12.4 \mathrm{mg}$ (about $0.2 \mathrm{mg} / \mathrm{kg}$-day) are reported in countries with high cereal intake (Friberg et al., 1986).

Drinking water generally results in an intake of less than $0.2 \mathrm{mg}$ $(0.003 \mathrm{mg} / \mathrm{kg}$-day), although some mineral waters can increase this amount by more than threefold (Friberg et al., 1986). One study from Greece reported drinking water concentrations of manganese in excess of $2 \mathrm{mg} / \mathrm{L}$, which would result in daily intakes in the range of 0.06 to $0.07 \mathrm{mg} / \mathrm{kg}$-day (EPA, 1994a). 
Manganese toxicity

Manganese is an essential nutrient. The adult ESADDI ranges from 0.03 to $0.07 \mathrm{mg} / \mathrm{kg}$-day (Friberg et al., 1986). The EPA NOAEL for drinking water is set at $0.005 \mathrm{mg} / \mathrm{kg}$-day, while the lowest-observed-adverse-effect level (LOAEL) for drinking water is $0.06 \mathrm{mg} / \mathrm{kg}$-day (EPA, 1994a). The EPA RfD for drinking water is $0.005 \mathrm{mg} / \mathrm{kg}$-day. The RfD for ingested food is $0.14 \mathrm{mg} / \mathrm{kg}$-day. Manganese in drinking water may be more bioavailable (i.e., more readily absorbed) than manganese in dietary food sources. This bioavailability would result in toxic effects at lower ingested doses in drinking water than in food (EPA, 1994a).

Industrial settings are the largest source of data on chronic manganese toxicity. The data indicate that inhalation of manganese can result in a central nervous system disorder characterized by irritability, difficulty in walking, speech disturbances, and compulsive behavior that may include running, fighting, and singing. With continued exposure, this condition can progress to a mask-like face, retropulsion or propulsion, and a Parkinson-like syndrome. These effects are largely irreversible, although some recovery can be expected when exposure ceases (DHHS, 1992b). Metal-chelating agents are ineffective in treatment, but L-dopa has been effective in treatment (Casarett and Doull, 1991).

Information on the effects of manganese ingestion is limited. Because effects from drinking water seem to differ from effects from food sources, only studies on water consumption will be considgered here. A Japanese study of 25 people drinking well water with manganese concentrations of $14 \mathrm{mg} / \mathrm{L}(0.4 \mathrm{mg} / \mathrm{kg}$-day estimated intake) reported symptoms of intoxication, including a mask-like face, muscle rigidity and tremors, and mental disturbances. Two deaths ( 8 percent) occurred among the intoxicated people. A Greek study of more than 4000 adults at least 50 years old drinking water with manganese concentrations varying from 0.081 to $2.3 \mathrm{mg} / \mathrm{L}$ lestimated intakes at $2 \mathrm{~L}$ per day for a $70-\mathrm{kg}$ individual range from 0.002 to $0.07 \mathrm{mg} / \mathrm{kg}$-day) showed varying degrees of neurological effects in individuals drinking from 0.007 to $0.07 \mathrm{mg}$ manganese/kg-day, but no effects in individuals drinking less than 0.005 $\mathrm{mg} / \mathrm{kg}$-day (Kondakis et al., 1989). However, there are many limitations to these studies which make data interpretation difficult. Among the limitations is uncertainty regarding the exposure level and whether the observed effects were solely attributable to manganese. Despite these limitations, the similarity of the observed effects between oral exposure and inhalation exposure suggests that excess manganese intake by humans might lead to neurological injury (DHHS, 1992b).

The chemical form of manganese has complex effects on its toxicity. Although the more soluble ferms are more readily absorbed from the gastrointestinal tract, they also appear to clear more rapidly. Exposure to insoluble forms results in lower manganese absorption but higher chronic tissue levels and therefore greater toxicity (EPA, 1994a). Information is limited on the effects of the different forms of manganese. 
Few data are available on manganese toxicity in infants, but infants are probably more susceptible to manganese toxicity due to greater absorption and greater penetration into the central nervous system (EPA, 1994a; Friberg et al., 1986). Figure $\mathbf{5 . 9}$ summarizes manganese toxicity as a function of dose.

\subsubsection{Molybdenum}

\section{Absorption}

Molybdenum absorption in the gastrointestinal tract depends on the species of the metal. Inorganic hexavalent forms such as molybdenum trioxide, sodium molybdate, and ammonium molybdate are readily absorbed from both food and water, whereas molybdenite is not. Human absorption rates of 40 to 70 percent have been observed for the soluble forms of molybdenum (Tipton et al., 1969; Robinson et al., 1973; Alexander et al., 1974).

\section{Tissue accumulation and clearance}

In humans, the highest concentrations of molybdenum occur in the liver, kidney, and adrenals (Casarett and Doull, 1991). With normal dietary intake, molybdenum levels in the body slowly increase until approximately age 20 , then begin to decline steadily. Urine is the principal excretion route in humans. Human studies indicate that the biological half-life in humans is considerably longer than in animals and may be as long as 2 weeks (Rosoff and Spencer, 1964).

\section{Environmental sources of molybdenum}

Molybdenum occurs naturally in combination with other metals, including uranium, lead, iron, cobalt, and calcium. Native soil concentrations can vary by as much as 2 orders of magnitude, from 0.1 to $10 \mathrm{mg} / \mathrm{kg}$, leading to large variations in molybdenum concentrations in plant materials. Natural concentrations in ground water are reported from 0.00011 to $0.0062 \mathrm{mg} / \mathrm{L}$. Human dietary intake of molybdenum is estimated at 0.05 to $0.24 \mathrm{mg}$ per day $(0.0007$ to $0.003 \mathrm{mg} / \mathrm{kg}$-day). The contribution of drinking water is estimated to range from 0 to 95 percent. The nutritional intake range for molybdenum is from 0.0015 to $0.0054 \mathrm{mg} / \mathrm{kg}$-day. No symptoms of molybdenum deficiency have been reported in humans. Nonetheless, molybdenum is an essential trace element that functions as a necessary constituent of several enzymes, including xanthine oxidase (which is involved in the metabolism of uric acid) and nitrate reductase (Friberg et al., 198(5).

\section{Molybdenum toxicity}

Acute toxic effects of molybdenum have not been reported. No adverse health effects have been reported with a chronic intake of less than $0.008 \mathrm{mg} / \mathrm{kg}$-day of molybdenum. Molybdenum toxicity primarily is related to its interactions with copper and sulfur, leading to altered excretion patterns for these elements. 
Increased levels of molybdenum also increase the levels of xanthine oxidase, which is responsible for the production of uric acid. Uric acid can accumulate in joints, leading to symptoms of gout and other joint disorders.

A molybdenum intake of 0.008 to $0.022 \mathrm{mg} / \mathrm{kg}$-day can produce a mineral imbalance as a result of increased copper excretion. Copper excretion is reported to double with molybdenum intake at the upper end of this range. Copper is an essential nutrient important in many metabolic pathways, including hemoglobin synthesis and furiction. A copper deficiency resulting from excess excretion will impair the oxygen-carrying capacity of the blood, and severe copper deficiencies can lead to hypochromic microcytic anemia. In humans, gout-like symptoms and joint deformities are reported in regions of Russia where elevated molybdenum conceritrations in soil and subsequent increased molybdenum concentrations in food lead to molybdenurn intakes in the range of 0.14 to $0.21 \mathrm{mg} / \mathrm{kg}$-day. Figure 5.10 summarizes the health effects of molybdenum as a function of dose.

\subsubsection{Nitrate}

\section{Absorption}

Ingested nitrate converts in the gut to the toxic nitrite ion, which absorbs readily. The conversion rate depends on both gut flora and $\mathrm{pH}$, with a more rapid conversion in a higher $\mathrm{pH}$ environment. Infants have a higher gut $\mathrm{pH}$, which is more conducive to bacteria growth. Therefore, the combination of an alkaline environment and increased bacterial conversion increases the production of nitrite from nitrate in infants, resulting in higher blood nitrite levels for a given dose of nitrate. In healthy adults, nitrates are absorbed rapidly from the upper intestine. This rapid absorption reduces the contact time with gut flora, thereby reducing the conversion to nitrite and the resultant toxicity.

\section{Tissue accumulation and clearance}

After absorption, the nitrite ion binds to hemoglobin in the blood and oxidizes it, thereby reducing the oxygen-carrying capacity of the blood and decreasing the rate of oxygen release. The oxidized hemoglobin is called methemoglobin and can be reduced back to normal hemoglobin enzymatically by methemoglobin reductase. Infants are more sensitive to these effects because of 1) the presence of fetal hemoglobin, which is more sensitive to oxidation by nitrite, and 2) lower activity of methemoglobin reductase, meaning the methemoglobin remains oxidized for a longer period. Certain individuals have a rare genetic deficiency in methemoglobin reductase and therefore exhibit higher levels of circulating methemoglobin. A.lthough these individuals develop alternate metabolic pathways to maintain adequate levels of circulating hemoglobin in the normal state, exposure to high levels of nitrate can result in excessive levels of methemoglobin in these individuals. 


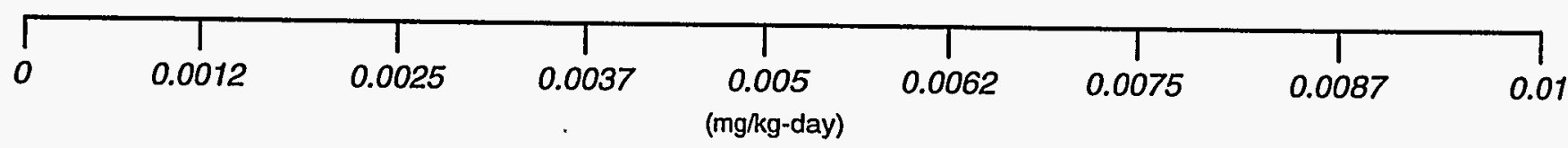

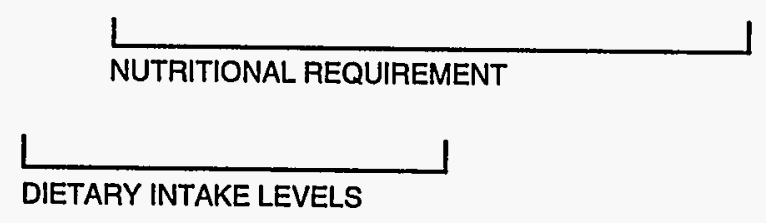

$\triangle$ ORAL Rid (0.005 mg/kg-day)

NO OBSERVED EFFECT LEVEL 
In healthy adults, the estimated half time for 80 to 100 percent of methemoglobin reductase to convert methemoglobin back to hemoglobin ranges from 6 to 24 hours for theoretical methemoglobin levels (Bolyai et al., 1972).

\section{Environmental sources of nitrate}

Nitrates accumulate in soils from the application of fertilizers, human and animal waste, bacterial nitrogen fixation, mineral dissolution, and plant and animal tissue breakdown. These nitrates can filter through the soil into ground water. Nitrate concentrations in well water have been reported to exceed $440 \mathrm{mg} / \mathrm{L}$, or 10 times the current regulatory levels (Lee, 1970).

Nitrate bioaccumulation from soil and water to plants results in a wide range of nitrate concentrations in fresh fruits and vegetables, with levels as high as $2000 \mathrm{mg} / \mathrm{kg}$ reported in beets and $9000 \mathrm{mg} / \mathrm{kg}$ in radishes (Kamm et al., 1965; Smith, 1966). Nitrate accumulation in plant material is increased by factors such as drought, high temperatures, cloudiness, and insect and herbicide damage. Nitrates and nitrites also are used to preserve meats, especially corned or smoked products.

\section{Nitrate of toxicity}

The primary effect of nitrate toxicity is methemoglobinemia, which is a function of the balance between circulating levels of nitrite and methemoglobin reductase activity. A very high acute dose can produce the same toxicity as a lower dose that slowly increases the concentration of methemoglobin over time. Therefore, the acute and chronic toxicities of nitrate are summarized together. To allow easier comparisons between ingested doses of nitrate and ground water levels, dose ranges are presented in terms of nitrate intake. Nitrate exposure levels are frequently converted to the nitrogen concentration in the nitrate by dividing the nitrate number by 4.4 . Therefore, $44 \mathrm{mg} / \mathrm{L}$ nitrate is equivalent to $10 \mathrm{mg} / \mathrm{L}$ nitrate-nitrogen.

Symptoms of methemoglobinemia can be correlated with the percentage of methemoglobin in the blood as follows: less than 10 percent methemoglobin produces no symptoms in individuals; more than 25 percent methemoglobin produces weakness, rapid pulse, and tachypnea (rapid breathing); and more than 50 to 60 percent methemoglobin can be fatal (EPA, 1994a). These symptoms reflect the progressive decrease in available oxygen. Infants are the most sensitive population to nitrate toxicity because they produce methemoglobin more efficiently than other age groups from the source amount of nitrate. The exposure route for infants is contaminated water used in formula.

No symptnms of toxicity have been reported with nitrate intakes below $7 \mathrm{mg} / \mathrm{kg}$-day in infants. Mild symptoms such as weakness, rapid pulse, and rapid breathing occur with intakes from 7 to $30 \mathrm{mg} / \mathrm{kg}$-day. The severity of these symptoms increases as increased nitrate intake results in greater levels of methemoglobin and therefore a reduced availability of oxygen. Cyanosis, or a 
blue appearance to the skin, occurs, followed by unconsciousness as available oxygen is further reduced. The lowest reported fatal dose of chronic nitrate is $35 \mathrm{mg} / \mathrm{kg}$-day for an infant and $116 \mathrm{mg} / \mathrm{kg}$ (acute intake) for an adult. A wide range of nitrate intake can produce similar symptoms among individuals because of net differences in gut $\mathrm{pH}$, bacterial activity, and methemoglobin reductase activity. Figure $\mathbf{5 . 1 1}$ summarizes these health effects in infants as a function of dose.

Data on nitrate toxicity are based primarily on epidemiologic studies of human adults and infants who report to hospitals with symptoms of methemoglobinemia. Exposure doses have been back-calculated from sampling their drinking water, in most cases. Therefore, these data do not represent well-controlled studies with readily defined dosage ranges. Many of the water sources in these clinical studies showed contamination with bacteria, leading to the possibility that this bacterial exposure is a necessary cofactor in the development of methemoglobinemia. One laboratory study indicated that healthy infants could drink nitrate at $24 \mathrm{mg} / \mathrm{kg}$-day in solutions free of bacteria and show no symptoms of methemoglobinemia (EPA, 1994a).

Gastrointestinal distress has also been suggested as a cofactor in the development of methemoglobinemia. Infants with colic are more susceptible to nitrate-induced methemoglobinemia than healthy infants (EPA, 1994a).

\subsubsection{Selenium}

\section{Absorption}

$$
x
$$

Although approximately 90 percent of the water-soluble forms of selenium (such as selenite) are absorbed in the gastrointestinal tract in rats, humans show lower percentages of absorption (40 to 80 percent) (Bopp et al., 1982). Absorption by ruminants is only 30 to 35 percent, probably due to bacterial reduction in the rumen. Absorption of the less soluble elemental selenium or selenium sulfide is poor in rats (Medinsky et al., 1981; Cummins and Kimura, 1971).

\section{Tissue accumulation and clearance}

Human studies suggest similar distributions of selenium between humans and laboratory animals (Bopp et al., 1982). At low intake levels, selenium is retained and accumulates in the reproductive organs, brain, and thymus, with only transient accumulation in other organs. Selenite-derived selenium accumulates in the liver and kidneys more rapidly than selenium derived from selenate (Millar et al., 1973). There is some indication that organically bound forms of selenium exist in a separate, more bioavailable pool than either selenite or selenate.

Although urinary excretion is the primary route of elimination under normal dietary conditions (67 percent), in deficiency states fecal excretion is the major 


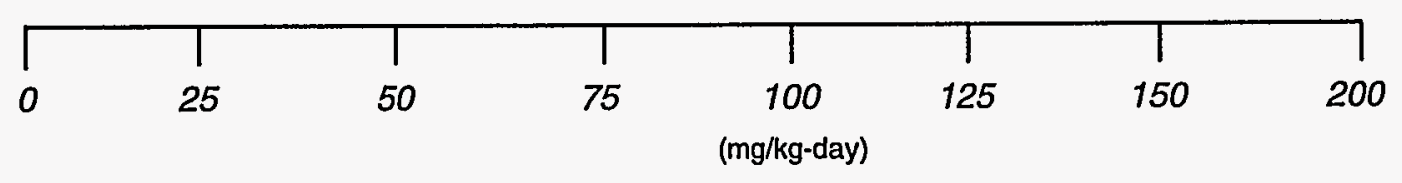

$\triangle$ ORAL REFERENCE DOSE ( $7 \mathrm{mg} / \mathrm{kg}$-day nitrate)

$$
\text { ᄂ }
$$

NO OBSERVED EFFECTS

MILD TOXICITY - WEAKNESS, RAPID PULSE, RAPID BREATHING

SEVERE TOXICITY - METHEMOGLOBINEMIA INCREASE, CYANOSIS, COMA

POTENTIALLY LETHAL METHEMOGLOBINEMIA

FIGURE 5.11

NITRATE TOXICITY RANGES FOR INFANTS 
pathway. At toxic doses, the major route of excretion is through expired air as dimethylselenide (50 to 60 percent) (Friberg et al., 1986). Although these data were obtained from rats, available data suggest that human excretion is similar (Bopp et al., 1982). Selenium elimination in humans follows three phases with the following half times: 1 day, 8 to 20 days, and 65 to 116 days.

\section{Environmental sources of selenium}

The main source of selenium for the general population is food such as seafood, meat, and grains. Dietary intake of selenium in the United States ranges from 0.0007 to $0.0029 \mathrm{mg} / \mathrm{kg}$-day. Selenium concentrations in ground water and surface water range from 0.00006 to $0.400 \mathrm{mg} / \mathrm{L}$, with highs of $6 \mathrm{mg} / \mathrm{L}$ reported (Friberg et al., 1986). Concentrations in public water supplies in the United States rarely exceed $0.010 \mathrm{mg} / \mathrm{L}$ (EPA, 1980). High selenium concentrations occur in volcanic rock $(0.120 \mathrm{mg}$ per gram) and in sandstone uranium deposits (1 $\mathrm{mg}$ per gram). The soil content of selenium varies widely, as does the rate of accumulation by plants. Although grasses and grains do not accumulate selenium in concentrations greater than $50 \mathrm{mg} / \mathrm{kg}$, some plants can accumulate as much as $10,000 \mathrm{mg} / \mathrm{kg}$ if grown in high-selenium regions. These high-accumulating plants are generally not used as food sources but can produce toxic effects if consumed by livestock.

\section{Selenium toxicity}

Selenium is an essential nutrient. The RDA for adults is 0.04 to $0.07 \mathrm{mg} / \mathrm{kg}$-day (equivalent to 0.006 to $0.001 \mathrm{mg} / \mathrm{kg}$-day for a $70-\mathrm{kg}$ person). Although some biochemical alterations, including prolonged prothrombin time and reduced blood glutathione concentrations, can be observed with intakes of selenium from 0.0107 to $0.0121 \mathrm{mg} / \mathrm{kg}$-day, no clinical signs of selenosis are observed with these intakes. Mild toxicity, including hair loss or breakage, thickening and brittleness of nails, and a garlic odor in dermal excretions and breath, were reported in human populations with dietary intakes of selenium from $0.015 \mathrm{mg} / \mathrm{kg}$-day. However, selenium intake as low as $0.013 \mathrm{mg} / \mathrm{kg}$-day can produce symptoms of selenosis such as hair and nail loss in susceptible populations.

Persistent clinical symptoms of selenosis are attributed to the chronic dietary intake of selenium by human populations living in areas of China with high selenium concentrations in soil (from 7 to $12 \mathrm{mg} / \mathrm{kg}$ ). Clinical signs observed include the characteristic garlic odor of excess selenium excretion in the breath and urine, thickened and brittle nails, hair and nail loss, lowered hemoglobin levels, mottled teeth, skin lesions, and central nervous system abnormalities (peripheral anesthesia, acroparesthesia, and pain in the extremities). Estimated selenium dietary intake was reported to be $0.018 \mathrm{mg} / \mathrm{kg}$-day for adult women and $0.021 \mathrm{mg} / \mathrm{kg}$-day for adult men (Yang et al., 1989a; 1989b). The average blood selenium concentration associated with this selenium intake level was $1.3 \mathrm{mg} / \mathrm{L}$ (ranging from 1.05 to $1.85 \mathrm{mg} / \mathrm{L}$ ). In the same study, symptoms of chronic selenosis (hair and nail loss and below-normal hemoglobin levels) were 
reported with a selenium intake of $0.071 \mathrm{mg} / \mathrm{kg}$-day. A serious outbreak of selenium poisoning, including the possible occurrence of neurotoxic effects such as peripheral anesthesia, acroparesthesia, and pain in extremities, was observed with selenium intake of $0.54 \mathrm{mg} / \mathrm{kg}$-day in both women and men. Protein intake by members of this population is unknown. Figure 5.12 summarizes these heaith effects as a function of dose.

Ingestion of 350 to $4300 \mathrm{mg}$ (5 to $61 \mathrm{mg} / \mathrm{kg}$ ) of selenium by adults has produced vomiting, diarrhea, abdominal cramps, numbness in arms, and marked hair loss and irregular menstrual bleeding in women. Higher intakes can result in unsteady gait, cyanosis of mucous membranes, labored breathing, and sometimes death.

Symptoms of alkali disease and blind staggers have been seen in livestock grazing long-term on selenium-accumulating plants in areas with high soil selenium content (Rosenfeld and Beath, 1964). These symptoms include neurological dysfunction such as impaired vision, ataxia, disorientation, and respiratory distress.

\subsubsection{Sodium}

\section{Absorption}

Sodium is rapidly and fully absorbed from the gastrointestinal tract. The skin and lungs also absorb sodium rapidly, by simple diffusion and ion exchange (National Research Council, 1980).

\section{Tissue accumulation and clearance}

Sodium is the major extracellular ion. The sodium ion is essential to the regulation of the acid-base balance and is an important contributor to extracellular osmolarity. It is an essential constituent in the electrophysiological functioning of cells and is required for impulse propagation in excitable tissues. Furthermore, sodium is essential for active nutrient transport, including the active transport of glucose across the intestinal mucosa. About 30 to 40 percent of the body's sodium is thought to be stored on the surfaces of the bone crystals, where it is easily recovered if blood sodium levels drop.

Sodium is excreted mainly in urine, with appreciable amounts also excreted in feces, sweat, and tears (Venugopal and Luckey, 1978). Mammalian renal sodium excretion is a two-phase process involving glomerular filtration and reabsorption in proximal tubules; of about 600 grams of sodium involved in 24-hour glomerular filtration, approximately 99.5 percent is reabsorbed in human adults. A homeostatic mecha.rism for sodium functions at the renal excretory level. 


\begin{tabular}{llll|ll|ll|l}
\hline & 0.0025 & 0.005 & 0.0075 & $\begin{array}{c}0.01 \\
\text { (mg/kg-day) }\end{array}$ & 0.0125 & 0.015 & 0.0175 & 0.020
\end{tabular}

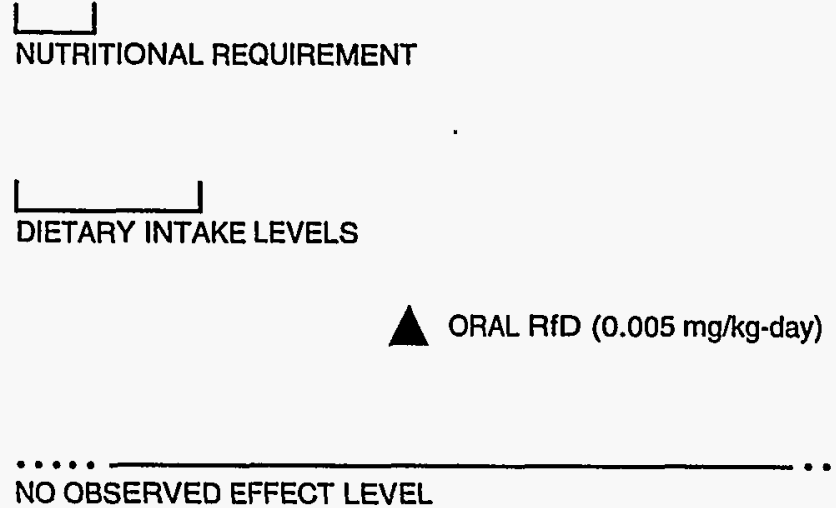

FIGURE 5.12 SELENIUM TOXICITY RANGES 


\section{Environmental sources of sodium}

The total sodium intake is influenced mainly by the amount of salt (sodium chloride) added to food, the inherent salt content of the foods consumed, and the amount of other sodium salts in the diet and in medication. Sodium is a natural constituent of both vegetable and animal products in varying concentrations. Other sources of sodium are drinking water, cooking water, soft drinks, and alcoholic beverages.

At 2 months, infants consume approximately $300 \mathrm{mg}$ of sodium a day; at 12 months, approximately $1400 \mathrm{mg}$ per day. Human breast milk contains 161 $\mathrm{mg} / \mathrm{L}$, and cow's milk contairs approximately $483 \mathrm{mg} / \mathrm{L}$ (Carson et al., 1986).

No RDA is set for sodium. The National Research Council recommends limiting daily sodium intake to less than $2400 \mathrm{mg}(34 \mathrm{mg} / \mathrm{kg}$-day); the American Heart Association recommends limiting dietary sodium intake to $3000 \mathrm{mg}$ daily. A healthy person requires about: $115 \mathrm{mg}$ sodium daily $(1.6 \mathrm{mg} / \mathrm{kg}$-day), yet sodium dietary intake is estimated at 57 to $85 \mathrm{mg} / \mathrm{kg}$-day. However, dietary sodium intakes as high as $134 \mathrm{mg} / \mathrm{kg}$-day are reported (National Research Council, 1980).

The sodium content of drinking water is extremely variable. Analyses of water supply systems indicate sodium concentrations in 630 systems range from less than 1 to $402 \mathrm{mg} / \mathrm{L}$ (resulting in sodium intake from less than 0.03 to $11 \mathrm{mg} / \mathrm{kg}$-day), with 42 percent greater than $20 \mathrm{mg} / \mathrm{L}$ and 3 percent over $200 \mathrm{mg} / \mathrm{L}$ (Carson et al., 1986).

\section{Sodium toxicity}

Symptoms of acute sodium chloride toxicity accompanied by visible edema may occur in healthy adult males with an intake as low as 35 to 40 grams of salt per day $(200$ to $223 \mathrm{mg} / \mathrm{kg}$-day, because sodium is 39 percent of the weight of sodium chioride) (Meneely and Battarbee, 1976). The mean lethal dose of sodium for humans is reportedly $3230 \mathrm{mg} / \mathrm{kg}$ (Venugopal and Luckey, 1978).

Epidemiological studies indicate that long-term, excessive sodium intake is one of many factors associated with hypertension in humans. A high sodium-topotassium ratio in the diet may be detrimental to persons susceptible to high blood pressure. Some adults, however, tolerate chronic intake above $\mathbf{4 0}$ grams of sodium chloride per day (equivalent to $223 \mathrm{mg} / \mathrm{kg}$-day) (Carson et al., 1986).

Research indicates that critical levels of sodium ingestion cause blood pressure to rise with age, leading to hypertension. Freis (1976) reports that with sodium intake below $227 \mathrm{mg}$ per day ( $3 \mathrm{mg} / \mathrm{kg}$-day for a $70-\mathrm{kg}$ adult), hypertension was absent. In the range of 227 to $1591 \mathrm{mg}$ per day (3 to $23 \mathrm{mg} / \mathrm{kg}$-day for a 70-kg adult), a few cases of hypertension may appear, while in the range of 1591 to $8000 \mathrm{mg}$ per day (23 to $114 \mathrm{mg} / \mathrm{kg}$-day for a $70-\mathrm{kg}$ adult), approximately 15 percent of adults exhibit hypertension. When sodium intake 
rises above $8000 \mathrm{mg}$ per day, hypertension may be found in about 30 percent of the population. Because sodium chloride is present in nearly all processed and packaged foods, limiting dietary intake is difficult. The average daily dietary intake in the United States often causes hypertensive effects.

Drinking water generally contains relatively low levels of sodium and therefore does not significantly contribute to the total intake unless sodium is at higherthan-average levels in the water supply. However, people on sodium-restricted diets can obtain a significant portion of daily sodium from drinking water.

Because the kidney is the major organ involved in regulating sodium balance, individuals with compromised kidney function may be placed on a low-sodium diet. Other individuals may be on low-sodium diets to control hypertension. Because of the high prevalence of such individuals in our society, the American Heart Association has proposed that public drinking water supplies in the United States adopt a standard of $20 \mathrm{mg} / \mathrm{L}$ sodium (Calabrese and Tuthill, 1977). This standard measure would limit additional sodium intake from drinking water to approximately $0.6 \mathrm{mg} / \mathrm{kg}$-day for a $70-\mathrm{kg}$ adult. Figure 5.13 summarizes the potential health effects of sodium as a function of dose.

\subsubsection{Sulfate}

\section{Absorption}

Sulfate absorption from the gastrointestinal tract is similar in humans and other animals. Generally, greater than 90 , percent absorption is reported for sulfate doses below $150 \mathrm{mg} / \mathrm{kg}$, decreasing to 50 to 75 percent as the dose increases into the grams-per-kilogram range.

\section{Tissue accumulation and retention}

Ingesting high levels of sulfate results in transient increases in both blood and urine concentrations. Approximately 50 percent of a $75-\mathrm{mg} / \mathrm{kg}$ dose is excreted over 72 hours. The urinary excretion mechanism is transport-limited and can become saturated at high doses of sulfate. Excess sulfate is also excreted in feces in its inorganic form. To date, no data indicate that sulfate accumulates, even with chronic ingestion of above-normal levels. However, extremely high chronic doses have not been examined in humans.

Sulfate is used to biosynthesize collagen, cartilage, and dentin and to form sulfate esters of both endogenous compounds (such as lipids and steroids) and exogenous compounds (such as phenols). Sulfation is important in detoxication pathways because it increases the solubility of these compounds, enhancing their excretion in the urine. Exposure to high concentrations of compounds that are conjugated with sulfate and excreted can produce a transient decrease in plasma sulfate concentrations. 

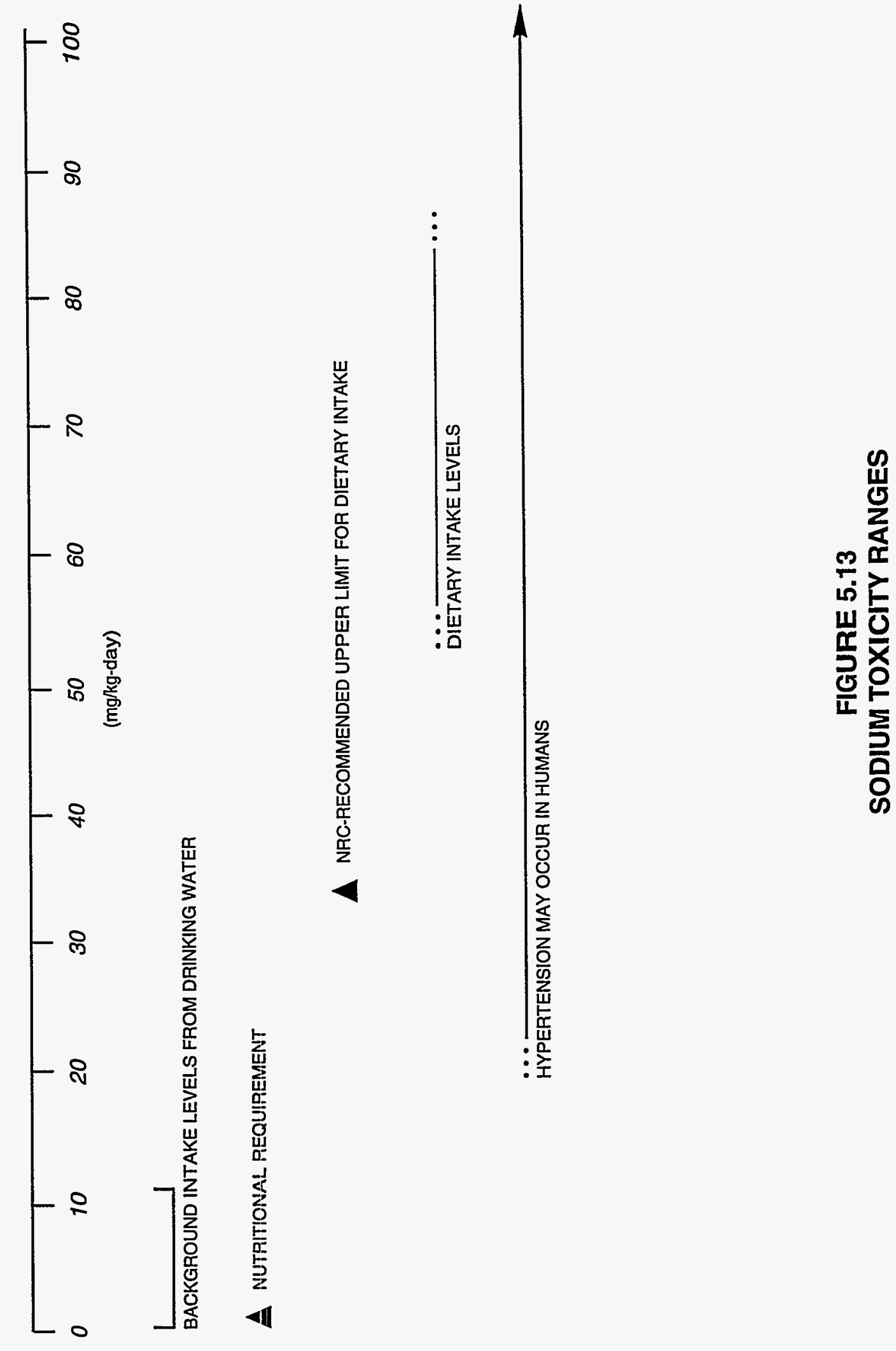


\section{Environmental sources of sulfate}

In 1978, drinking water sulfate concentrations in the western United States ranged from 0 to $820 \mathrm{mg} / \mathrm{L}$, with a mean concentration of $99 \mathrm{mg} / \mathrm{L}$ (EPA, $1992 \mathrm{c})$. The EPA estimates a normal sulfate intake range of 0.00023 to $0.0064 \mathrm{mg} / \mathrm{kg}$-day from air and up to $2.9 \mathrm{mg} / \mathrm{kg}$-day from drinking water in the western United States. Estimates on sulfate intake from food are not available.

\section{Sulfate toxicity}

The acute and chronic effects of sulfate toxicity differ more in severity than in symptoms or mechanisms. Therefore, this discussion will combine acute and chronic toxicity. As discussed above, no data indicate sulfate bioaccumulation with chronic exposure. Sulfate salts of magnesium and sodium are used medicinally as cathartics. High concentrations of unabsorbed sulfate salts in the gut can pull large amounts of water into the gut, greatly increasing the normal volume of feces. This action is also the basis of sulfate's toxic effects.

Toxicity in humans is primarily manifested in diarrhea; the severity of the diarrhea is dose-dependent. Chronic sulfate ingestion can result in persistent diarrhea, leading to ionic imbalance and dehydration similar to that seen with extremely high acute doses. Serious gastroenteritis is reported in some infants and adults drinking water Containing 400 to $1000 \mathrm{mg} / \mathrm{L}$ sulfate (EPA, 1992c). When drinking water is contaminated with sulfate, the taste of the water may make it unpalatable and reduce consumption. However, this is not necessarily the case. In regions with high sulfate concentrations in the drinking water (such as Saskatchewan), residents adapt to the taste and find the water palatable (EPA, 1992c). A lower water intake could compound the dehydration effects of the diarrhea. Extreme dehydration can lead to death. As with nitrate toxicity, infants appear to be the most susceptible population for sulfate-induced diarrhea. Also, some data indicate that diabetic and elderly populations with compromised kidney function may be more sensitive than healthy adults to the effects of sulfates (EPA, 1992c). Figure 5.14 summarizes these health effects as a function of dose.

Sulfate toxicity data are based primarily on epidemiologic studies of human adults and infants who report to hospitals with symptoms of sulfate exposure. In most cases, exposure doses have been back-calculated from sampling their drinking water. Therefore, these data do not represent well-controlled studies with readily defined dosage ranges.

\subsubsection{Uranium}

The uranium that occurs naturally at UMTRA Project sites consists of three radioactive isotopes: uranium-234, uranium-235, and uranium-238. More than 99 percent of natural uranium occurs in the form of uranium-238 (Cothern and Lappenbusch, 1983). Uranium-238 undergoes radioactive decay by emitting alpha particles to form uranium-234, thorium-230, radium-226, radon-222, 


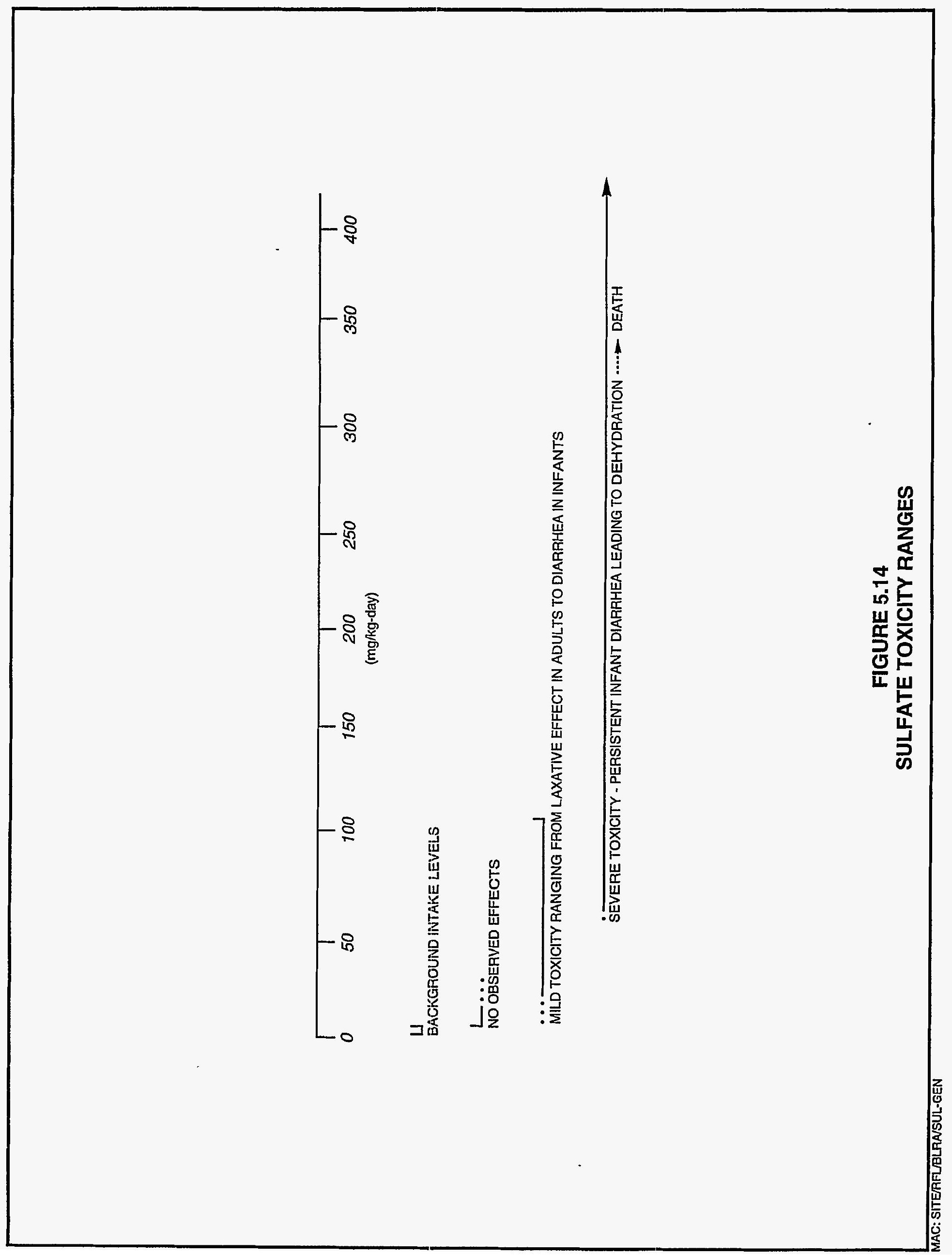


polonium-210, lead-210, and other radioisotopes. Figure 5.15 summarizes the radioactive decay chain of uranium-238 and uranium:-234. Because all natural uranium isotopes are radioactive, the hazards of a high uranium intake are from both its chemical toxicity and its potential radiological damage. The chemical toxicity of natural uranium is discussed here; the carcinogenic potential associated with exposure to radioactive isotopes of natural uranium is discussed in Section 5.3.

\section{Absorption}

Uranium absorption in the gastrointestinal tract depends on the solubility of the uranium compounds. The hexavalent uranium compounds, especially the uranyl salts, are water soluble, while tetravalent compounds generally are not (Weigel, 1983). However, only a small fraction of the soluble compounds is absorbed. Wrenn et al. (1985) have determined human gastrointestinal absorption rates of 0.76 to 7.8 percent.

Uranium may absorb through the skin when applied in concentrated solutions (the concentration level was not reported). The extent of absorption appears to be dose-dependent.

\section{Tissue accumulation and clearance}

In humans exposed to background levels of uranium, the highest concentrations were found in the bones, muscles, lungs, liver, and kidneys (Fisenne et al., 1988). Uranium retention in bone consists of a short retention half time of $\mathbf{2 0}$ days, followed by a long retention half time of $\mathbf{5 0 0 0}$ days for the remainder (Tracy et al., 1992).

In body fluids, uranium tends to convert into water-soluble hexavalent uranium (Friberg et al., 1986). Approximately 60 percent of the uranium in plasma complexes with low-molecular-weight anions (e.g., bicarbonates, citrates), while the remaining 40 percent binds to the plasma protein transferrin (Stevens et al., 1980). Following oral exposure to uranium, humans excrete more than 90 percent of the dose in the feces. Of the small percent that is absorbed (typically less than 5 percent), animal studies show that approximately 60 percent is excreted through the urine within 24 hours, whereas the remainder is distributed to the skeleton and soft tissue; 98 percent of that amount is excreted within 7 days (Ballou et al., 1986; Leach et al., 1984; Sullivan et al., 1986). A small portion of the absorbed uranium is retained for a longer period.

\section{Environmental sources of uranium}

Uranium is a ubiquitous element, present in the earth's crust at approximately $4 \mathrm{ppm}$. Uranium concentrations in ground water and surface water average 1 and $3 \mathrm{pCi} / \mathrm{L}$, respectively (NCRP, 1984). The extent of uptake from the soil into plant tissue depends on the plant species and the depth of its root system 


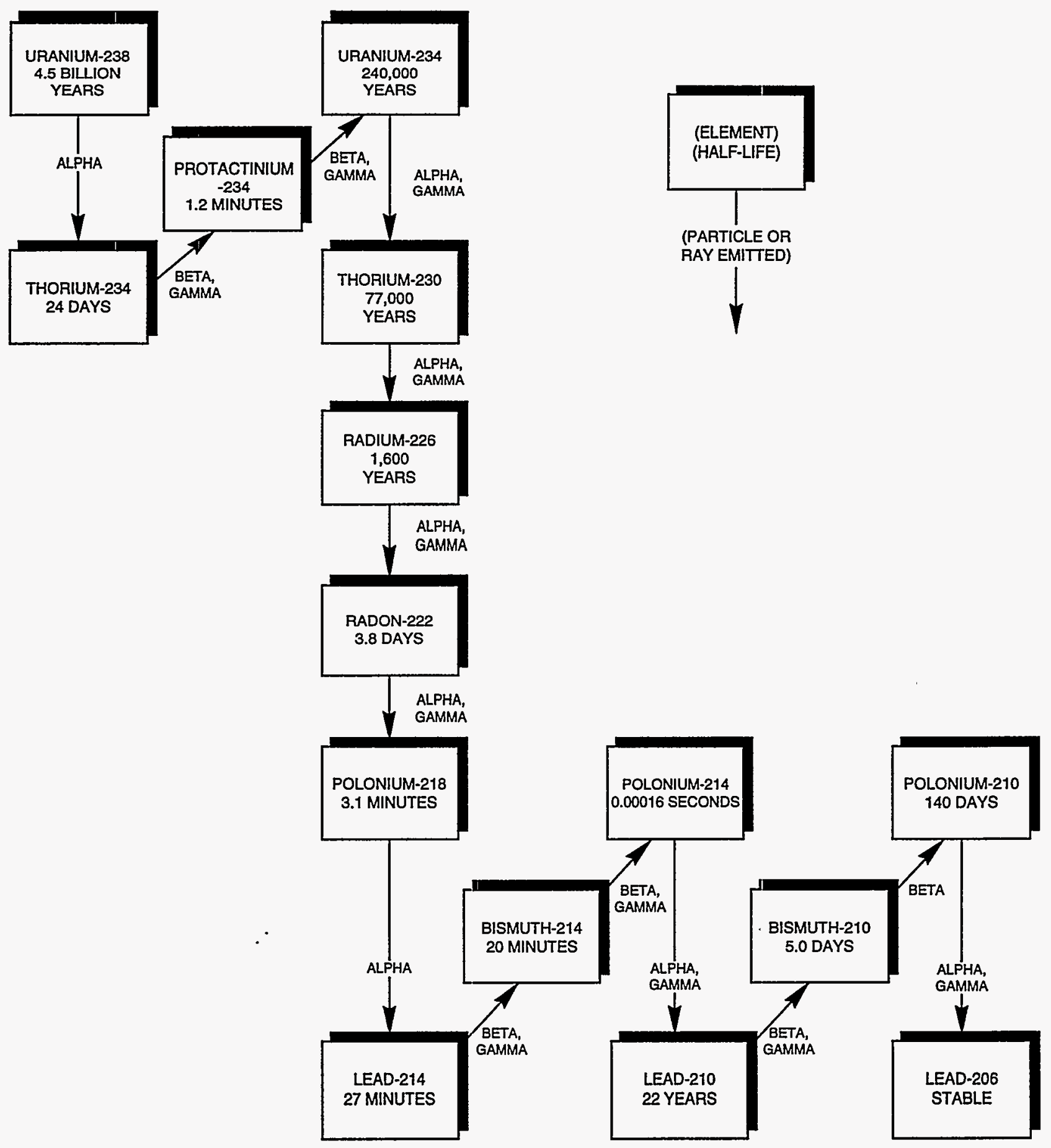

FIGURE 5.15

HALF-LIVES AND EMISSIONS FROM DECAY CHAIN OF URANIUM-238 
(Friberg et al., 1986). Tracy et al. (1992) report plant uranium concentrations averaging $0.075 \mu \mathrm{g} / \mathrm{kg}$ of fresh plant material.

The main dietary source of natural uranium for the general population is food (e.g., potatoes, grains, meat, and fresh fish) that may contain uranium concentrations between 10 and $100 \mu \mathrm{g} / \mathrm{kg}$ (Prister, 1969). The total uranium dietary intake from consuming average foods is approximately $1 \mu \mathrm{g}$ per day; approximately 20 to $\mathbf{5 0}$ percent of that total can come from drinking water. Cereals and vegetables, particularly root crops, probably contribute most to daily uranium intake (Friberg et al., 1986).

\section{Uranium toxicity}

No human deaths are reported that are definitely attributable to uranium ingestion; therefore, no lethal dose has been determined for humans. Lethal doses of uranium $\left(L D_{50,23}\right)$ are reported to be as low as $14 \mathrm{mg} / \mathrm{kg}$-day following 23-day oral exposure, depending on the solubility of the uranium compound tested (higher solubility compounds have greater toxicity), exposure route, and animal species. High doses of uranium cause complete kidney and respiratory failure.

No chronic toxic effects are reported in humans following oral exposure to uranium. Data from populations occupationally exposed to high concentrations of uranium compounds through inhalation and information from studies on experimental animals indicate that the critical organ for chronic uranium toxicity is the proximal tubule of the kidney (Friberg et al., 1986). In humans, chemical injury reveals itself by increased catalase excretion in urine and proteinuria. Dose-response data for the toxic effects of uranium on the human kidney are limited.

The lowest dose of uranyl nitrate that caused moderate renal damage was given to rabbits in diet at $2.8 \mathrm{mg} / \mathrm{kg}$-day (Maynard and Hodge, 1949); the EPA oral $\mathrm{RfD}$ of $0.003 \mathrm{mg} / \mathrm{kg}$-day is based on this study (EPA, 1994a). Figure 5.16 summarizes the health effects of uranium as a function of dose.

\subsubsection{Vanadium}

\section{Absorption}

Vanadium absorption from the gastrointestinal tract is low. The International Commission on Radiological Protection estimate for the absorption of soluble vanadium compounds is 2 percent (ICRP, 1960), but the World Health Organization states that absorption of even very soluble forms of vanadium is less than 1 percent from the gastrointestinal tract (WHO, 1988). Limited human data (from three individuals) have suggested that as much as 10 percent of a repeated oral dose may be absorbed (Proescher et al., 1917; Tipton et al., 1969). Soluble vanadium compounds that are inhaled and deposited are more 


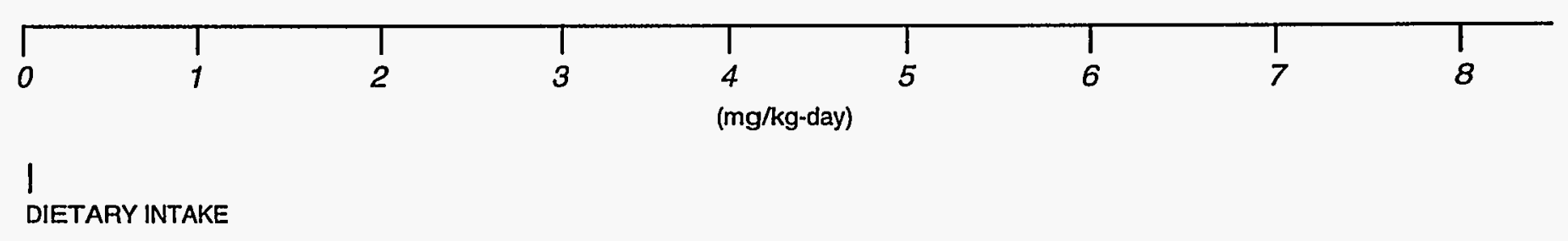

A ORALRfD (0.003 mg/kg-day)

No OBSERVED EFFECTS IN EITHER MICE OR RATS

(SUFFICIENT HUMAN DATA NOT AVAILABLE)

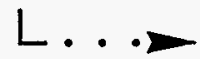

MILD TOXICITY

(RABBITS, RENAL DAMAGE) 
readily absorbed (about 25 percent) (WHO, 1988). Although soluble forms of vanadium may be absorbed through the skin, absorption via this route is probably minimal (EPA, 1977; WHO, 1988).

\section{Tissue accumulation and clearance}

Vanadium is found in all body tissues in concentrations ranging from $0.08 \mu \mathrm{g}$ per gram wet weight in spleen tissue to $0.14 \mu \mathrm{g}$ per gram in brain and heart tissue and $0.33 \mu \mathrm{g}$ per gram in aortic tissue (Yakawa and Suzuki-Yasumoto, 1980). Vanadium concentrations in human blood serum are reported to be 0.016 to 0.939 nanograms per milliliter $(\mathrm{ng} / \mathrm{mL})$. In hair, vanadium concentrations ranging from 20 to 60 nanograms (ng) per gram have been reported, with higher values found in manic-depressive patients (57 $\mathrm{ng}$ per gram) than in normal control groups (29 ng per gram).

The distribution of vanadium in humans following oral exposure may be extrapolated from animal studies. In acute-duration exposures, vanadium is rapidly distributed, primarily in the bones. After intermediate-duration exposure, vanadium concentrations reaching the tissues are low, with the kidneys, bones, liver, and lungs initially showing the highest levels.

Vanadium is an element and is not metabolized. However, in the body, there is an interconversion of two oxidation states of vanadium: vanadyl and vanadate. Vanadium can reversibly bind to the protein transferrin in the blood and then be taken up into erythrocytes. Vanadyl is taken up more slowly than the vanadate form, possibly due to the time required for the vanadyl form to oxidize to vanadate. Initially, vanadyl leaves the blood more rapidly than vanadate, possibly because of the slower vanadyl uptake into cells (Harris et al., 1984). Five hours after administration, blood clearance is essentially identical for the two forms.

Because vanadium is poorly absorbed in the gastrointestinal tract, a large percentage of vanadium in rats is excreted unabsorbed in the feces following oral exposure. In rats, the principal excretion route for the small absorbed portion of vanadium is through the kidneys. The mean urinary output per 24 hours is reported to be $10 \mu \mathrm{g}$.

\section{Environmental sources of vanadium}

Elemental vanadium does not occur in nature, but its compounds exist in more than $\mathbf{5 0}$ different mineral ores and in association with fossil fuels. The single largest release of vanadium to the atmosphere occurs through the combustion of fossil fuels, particularly residual fuel oils. The largest amount of vanadium released to soil and water occurs through natural weathering of geological formations (Byerrum et al., 1974; Van Zinderen Bakker and Jaworski, 1980). 
Food constitutes the major source of exposure to vanadium for the general population (Friberg et al., 1986). As a whole, dietary intake is estimated to be 6 to $18 \mu \mathrm{g}$ per day (Pennington and Jones, 1987), although other estimates from older studies using different (and possibly less sensitive) analytical methods have been as high as $2 \mathrm{mg}$ per day (Schroeder et al., 1963).

Drinking water is not considered an important source of vanadium exposure for the general population. Water samples taken from across the United States show 92 percent with values below $10 \mu \mathrm{g} / \mathrm{L}$. Typical values appear to be around $1 \mu \mathrm{g} / \mathrm{L}$ (Friberg et al., 1986). The estimated daily intake of vanadium by inhalation is $1 \mu \mathrm{g}$ (Byrne and Kosta, 1978).

Although vanadium is considered an essential element for chickens and rats, there is no certainty about human dietary requirements. For animals, the daily requirement is about 10 to $25 \mu \mathrm{g}$ per day (Pennington and Jones, 1987).

\section{Vanadium toxicity}

The major adverse health effect to humans from vanadium is seen in workers exposed to large amounts of vanadium pentoxide dusts. The probable oral lethal dose of vanadium pentoxide for humans is between 5 and $50 \mathrm{mg} / \mathrm{kg}$ (Gosselin et al., 1976).

Systemic effects of vanadium exposure have been observed in the liver, kidneys, nervous and cardiovascular systems, and blood-forming organs. Metabolic effects include interference with the biosynthesis of cystine and cholesterol, depression and stimulation of phospholipid synthesis, and at higher concentrations, inhibition of serotonin oxidation. Other effects of vanadium on mammalian metabolism include depression of phospholipid synthesis (Snyder and Cornatzer, 1958), reduction of coenzyme $Q$ levels in mitochondria (Aiyar and Sreenivasan, 1961), and stimulation of monoamine oxidase, which oxidizes serotonin (Perry et al., 1955).

Vanadium salts were given to patients in several studies to reduce cholesterol levels (Curran et al., 1959; Somerville and Davies, 1962; Dimond et al., 1963; Schroeder et al., 1963). The vanadium doses in these studies varied from 7 to $30 \mathrm{mg}$ per day (equivalent to 0.1 to $0.4 \mathrm{mg} / \mathrm{kg}$-day for a $70-\mathrm{kg}$ person).

Transient decreases in serum cholesterol levels were observed in some patients, as were loosened stool or diarrhea and intestinal cramps. Green tongue, a hallmark of vanadium exposure, was observed in all patients.

A relationship between the concentration of vanadium in drinking water and the incidence of dental caries in children is reported by Tank and Storvick (1960). Dental caries incidence in children aged 7 to 11 years was reduced three times (compared to controls) by applying ammonium vanadate in glycerol to the teeth (Belehova, 1969). This relationship was not found in other studies (Hadjimarkos, 1966; 1968). 
Elevated tissue levels of vanadium may be important in the etiology of manicdepressive illness. Improvement after treatment with ascorbic acid or reduced vanadium intake was seen both in manic and depressed patients.

Although animal studies have reported impaired conditioned reflexes following vanadium doses from $0.05 \mathrm{mg} / \mathrm{kg}$-day (after 6 months of exposure) to $0.5 \mathrm{mg} / \mathrm{kg}$-day (after 21 days of exposure), effects on the nervous system were not observed in humans following repeated oral administration of vanadium. Workers exposed by inhalation to fairly high concentrations of vanadium compounds have reported nonspecific symptoms, including headache, weakness, vomiting, nausea, and ringing of the ears (WHO, 1988).

Available data on vanadium toxicity are insufficient to evaluate its effect on cholesterol levels, iron metabolism, blood-cell production, and mutagenesis. However, due to poor absorption from the gut, the metal is not considered very toxic following oral administration (WHO, 1988). The EPA oral RfD of $0.007 \mathrm{mg} / \mathrm{kg}$-day was obtained from a chronic drinking water study with vanadium sulfate in rats (EPA, 1987; EPA, 1994b). Figure 5.17 summarizes the toxicity of vanadium as a function of dose.

\subsection{CONTAMINANT INTERACTION}

Some information is available on potential interactions between contaminants found at UMTRA sites. However, discussions of potential interactions can be presented only qualitatively. In addition to physiological variables between individuals that can affect toxicity, uncertainties in interactions also result from 1) differences in the relative exposure concentrations of the different contaminants compared to the concentrations tested experimentally; and 2) the presence of additional ground water constituents that may occur in sufficient quantities to modify predicted toxicities even though they themselves are not considered contaminants of potential concern for human health. Therefore, the interactions described below should be recognized as factors that can influence predicted toxicities, although the precise nature and magnitude of that influence cannot be determined.

A primary concern at the Rifle site is the potential for nitrate-sulfate interactions. No clear data are available to assess this interaction, but the epidemiological evidence suggests that in infants, gastrointestinal upset, such as that caused by sulfate, could increase infants' sensitivity to methemoglobinemia produced by nitrates. However, it is also possible that sulfate-induced diarrhea could decrease the nitrate-reducing bacteria in the intestine, thereby reducing nitrate toxicity.

Interactions between nitrate, sulfate, and hemoglobin also occur. However, no studies have been found that address the potential interactions in a combined exposure to high concentrations of both nitrate and sulfate. Nitrate has been used to treat hydrogen sulfide poisoning. The hydrogen sulfide anion binds to 

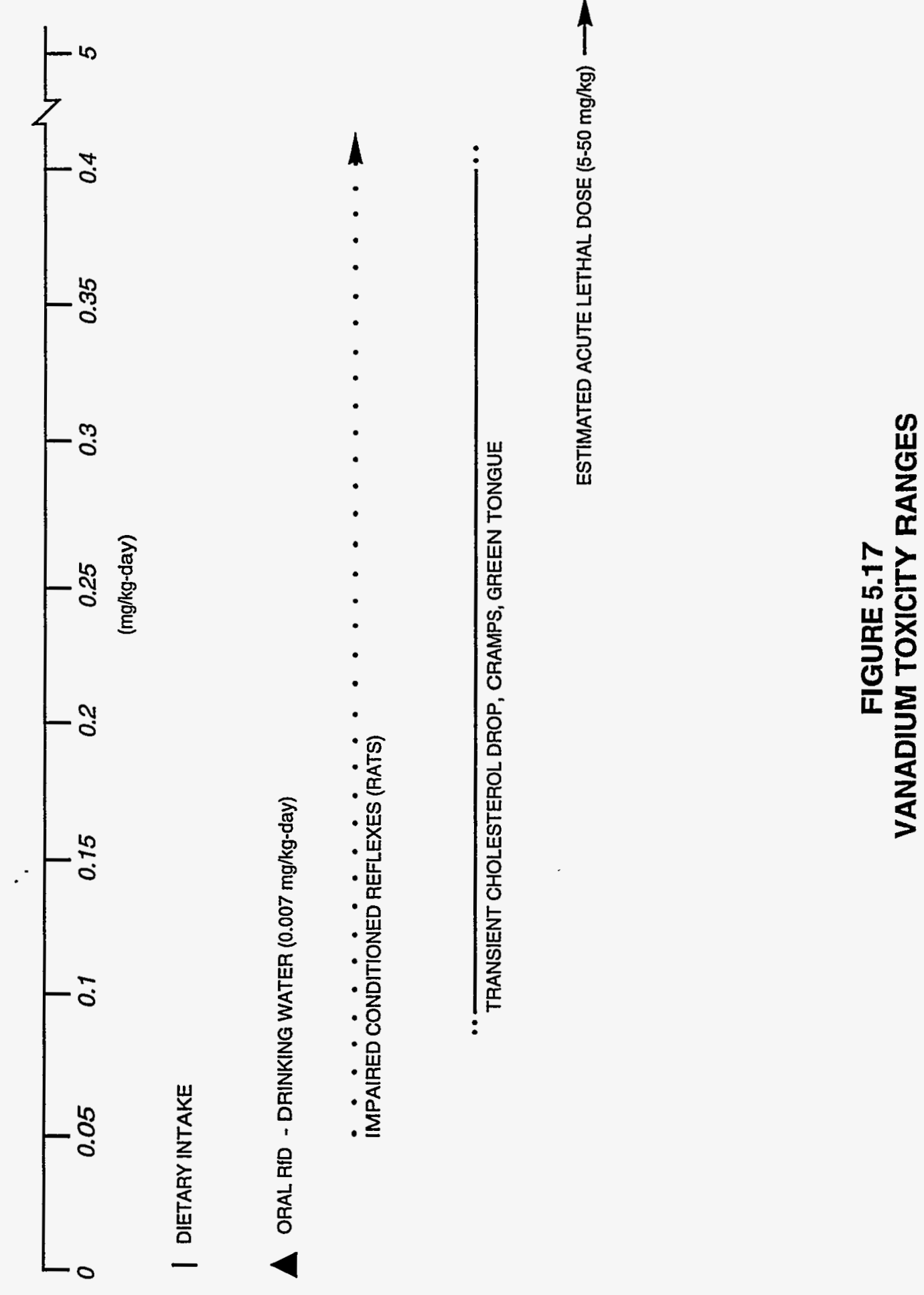
methemoglobin to form sulfmethemoglobin, effectively removing the circulating hydrogen sulfide anion. Additional data are needed to assess the likelihood of hydrogen sulfide ion formation with oral sulfate exposure or the subsequent formation or stability of sulfmethemoglobin.

Interactions between several similar metals can alter the predicted absorption, distribution in the body, metabolism, clearance, or toxicity of a metal of interest.

For example, cadmium, manganese, nickel, and selenium absorption can be considerably altered by a high calcium and iron or a low protein diet (Friberg et al., 1986; Nordberg et al., 1985). Absorption of cadmium, manganese, and selenium from the intestine may significantly decrease (up to fourfold in the case of cadmium) in the presence of high dietary iron, leading to decreased toxicity of cadmium, manganese, and selenium (DHHS, 1993b). High cadmium levels may inhibit manganese uptake. Conversely, high manganese levels lead to decreased iron absorption. Short-term effects of this type are probably the result of kinetic competition between iron and manganese for a limited number of binding sites on intestinal transport enzymes, while longer-term effects of excessive iron intake probably are due to adaptive changes in the intestinal transport capacity. On the other hand, iron deficiency anemia llow iron body stores) may substantially increase the gastrointestinal absorption of cadmium, lead and manganese, resulting in higher body burden and toxicity from these elements. Under conditions of high iron levels, nickel may inhibit the passive diffusion of iron, decreasing its gastrointestinal absorption and therefore toxicity, but only when iron is present as ferric ion (DHHS, 1993b). Based on geochemical models, ferrous ion is the dominant iron species in the alluvial ground water (Table 3.6). Therefore, nickel in the ground water at this site would decrease iron absorption. Iron absorption could additionally decrease in the presence of cobalt (Friberg et al., 1986; National Research Council, 1980).

Because cadmium, calcium, strontium, and lead are competitive with respect to their absorptive sites, an excess of any of these elements may partially inhibit the absorption of others. Excess lead may decrease calcium absorption through competition for a common transport system, and it may substitute in the bone for calcium. Thus, lead storage sites in the bone may form a continuous internal source of lead exposure, even after cessation of an external exposure. Calcium salts decrease the gastrointestinal absorption of fluoride (National Research Council, 1980). Increased ammonia absorption would be expected with simultaneous exposure to substances elevating gastrointestinal pH (ATSDR, 1990). This could augment local irritant effects of ammonia.

In addition, cadmium, manganese, and nickel can induce synthesis of the metalbinding protein metallothionein (DHHS, 1992b; DHHS, 1993a; DHHS, 1993b; Casarett and Douil, 1991). The formation of metallothionein-manganese and metallothionein-nickel complex would enhance manganese and nickel excretion, decreasing their toxicity. However, cadmium may enhance the nephrotoxicity and hepatotoxicity of nickel, because cadmium-damaged renal cells may be more susceptible to nickel, or cells not damaged by cadmium may be damaged 
by nickel (DHHS, 1993b). However, the mechanism of this interaction could not be ascertained. Metallothionein seems to have a paradoxical effect on the systemic toxicity of cadmium. This protein appears to bind cadmium and in this way protect certain organs, such as testes, from cadmium toxicity. At the same time, metallothionein may enhance cadmium nephrotoxicity, possibly because the cadmium-metallothionein complex is taken up by the kidney more readily than is the free ion. However, because cadmium, manganese, and nickel bind to metallothionein, in the continued presence of cadmium, manganese, and nickel, there may be competition for metallothionein binding sites.

A single study in mice suggests interaction between vanadium and manganese that alters behavioral development, unlike either element administered alone (DHHS, 1992b). Oral administration of vanadium alone may interfere with copper metabolism by inhibiting the intestinal absorption of copper, leading to copper deficiency. Copper deficiency may be triggered by the presence of molybdenum at levels observed at the Rifle site.

Selenium interacts with a wide range of elements, including arsenic, cadmium, cobalt, copper, and lead (Friberg et al., 1986). Seleniurn forms insoluble complexes with silver, copper, and cadmium. Selenium deficiency may develop in the presence of these other metals, as is seen with cobalt and copper. The formation of these complexes may reduce the toxicity of both selenium and the other metal (Casarett and Doull, 1991). Most of these interactions have been observed in laboratory animals or in livestock. The mechanisms are not completely understood in many cases. Often the selenium-metal complex binds in a stable complex to a larger protein than the metal alone, and a redistribution of this complex occurs away from the target tissues. Selenium and arsenic together can reduce their respective toxicities. However, some methylated metabolites of selenium can increase arsenic toxicity (DHHS, 1989). Sulfate also can interact with selenium, but the result is inconsistent. Sulfate can reduce some toxic effects of selenium but not others, such as liver damage, at high doses of selenium (DHHS, 1989).

Sulfate also interacts in a complex manner with molybdenum and copper. Ruminants seem to be the most susceptible species to imbalances between these elements. In ruminants, copper prevents molybdenum accumulation in the liver and may antagonize molybdenum absorption. Molybdenum can produce a functional copper deficiency, and sulfate augments the antagonism of molybdenum to copper. It has also been suggested that sulfide (reduced form of sulfate) can displace molybidate in the body (Casarett and Doull, 1991). In laboratory animal models, molybdenum toxicity is more pronounced when dietary copper intake is low (EPA, 1994a). In ruminants, both copper and sulfate can protect against molybdenum toxicity, and molybdenum and sulfide can inhibit copper toxicity. Possible interactions between molybdenum, iron, and fluoride are not well understood; however, it appears that molybdenum increases the toxicity of fluoride. 
Because ingestion of high levels of sulfate produces diarrhea that leads to dehydration, and ingestion of high levels of sodium and chloride leads to water retention, a physiological interaction might be expected to occur with simultaneous ingestion of all of them. However, available data do not predict the net effects of chronic ingestion of sulfate and sodium chloride at high concentrations. Although high-concentration sodium chloride solutions are used to treat diarrhea-induced hyponatremia and hypochloremic metabolic alkalosis, the electrolyte concentrations in these solutions are physiologically balanced. Disproportionately high sodium and chloride levels could intensify the electrolyte loss produced by severe diarrhea.

In animal studies, iron status affected the gastrointestinal absorption of uranium; however, the reported results were inconclusive (EPA, 1989c). No other information has been found on interactions of uranium with other metals. However, the common target organ suggests uranium, arsenic, cadmium, lead, vanadium, and nickel may interact and enhance kidney toxicity. No information on the influence of other compounds on the toxicity of antimony was found.

It should be noted that diarrhea-induced dehydration may lead to excessive concentration of the contaminants (those excreted in urine) in the kidney. Thus, diarrhea-induced dehydration may enhance the predicted toxicities of these contaminants. 


\subsection{HUMAN HEALTH RISK EVALUATION}

To evaluate potential human health risks to a population, the results of the exposure assessment are combined with the results of the toxicity assessment. The severity of adverse health effects is a function of how much of the contaminant an individual takes in. Exposure to lower levels of some contaminants are beneficial to health because they are essential nutrients. Exposure to higher levels of these same elements can cause adverse health effects or even death. Intake levels are estimated for each contaminant of potential concern based on an analysis of recent water quality data from the most contaminated onsite wells. Because levels of these contaminants vary between the two sites and between aquifers, potential risks are evaluated separately for the Old and New Rifle sites. For the New Rifle site, potential risks from the ingestion of ground water from the weathered Wasatch Formation are discussed relative to the potential risks identified for the alluvium.

No one is currently drinking contaminated ground water at the Old or New Rifle sites. Therefore, no one is at risk due to ground water consumption. The exposure concentrations that people would be exposed to from the other current exposure pathways (surface water and sediment ingestion and dermal contact, and fish ingestion) would not be expected to cause adverse health effects if they were the only source of exposure.

Risks presented here are potential future risks that could occur if a domestic well were installed at the sites and contaminated ground water were used as a primary drinking water source. This future ground water use scenario is a conservative estimate of potential risk, which will be used to determine the need for long-term risk management actions, and to provide information needed to support the completion of the UMTRA Ground Water Project.

\subsection{POTENTIAL FUTURE NONCARCINOGENIC RISKS}

Toxicity ranges developed in Section 5.0 are graphically superimposed on the simulated distributions of predicted exposures for the contaminants of potential concern developed in Section 4.0. Animal toxicity data are used, as noted, only when human toxicity data are not available. However, approximations are projected when the toxicity data are uncertain. The possible adverse health effects that could be expected at the predicted exposures are interpreted, not to determine the probability that the adverse health effect will occur but to predict the probability of specific exposures and to note whether adverse health effects are expected at these exposures. Potential future risk is estimated by the degree to which the predicted exposure distribution corresponds to potential adverse health effects.

To address the greatest potential source of exposure, probability distributions of potential exposures from the drinking water pathway are simulated. Potential exposures from other pathways are evaluated qualitatively to determine if adverse health effects would be expected from other exposures other than drinking water pathway. In evaluating potential noncarcinogenic adverse human health effects from ingesting ground water, children are assessed in these 
distributions as the population with the highest intake-to-body-weight ratio for ground water ingestion. Infants are assessed for nitrate and sulfate intakes because they are the subpopulation most sensitive to these contaminants. Adults are assessed to evaluate potential carcinogenic risks based on a lifespan of 70 years.

Potential risks identified for contaminants of potential concern on the site are incremental to any potential, naturally occurring risk from background levels of constituents. Potential risk from naturally occurring constituents in background ground water was not quantified separately.

\section{Potential noncarcinogenic health effects - Old Rifle}

Intake distributions for the contaminants of potential concern for the alluvial aquifer were simulated for the Old Rifle site. These constituents are arsenic, selenium, uranium, and vanadium, fluoride, iron, manganese, molybdenum, and sulfate. Figures 6.1 through 6.5 show intake distributions for molybdenum, sulfate, manganese, iron, and fluoride and possible adverse health effects relative to the dose levels in the distribution.

The exposure intakes generated for arsenic, selenium, and vanadium were determined to be at levels where toxic effects are not expected. Therefore, the exposure distributions for these contaminants are not presented in this risk assessment. The exposure distribution for uranium is not presented, although uranium could pose a health problem at Old Rifle. Approximately 100 percent of the exposure distribution for uranium at Old Rifle exceeds the toxicity value (RfD) where adverse health effects could occur. However adverse health effects have not been observed for uranium at low concentrations (such as those detected at Old Rifle). This discrepancy occurs largely because the toxicological database for uranium is incomplete and this uncertainty is considered in the EPA acceptable intake level (i.e., the RfD). Although low intake levels have not been associated with adverse health effects in humans or test animals, it is significant that most of the exposure distribution falls above the RfD criterion. This is because of the low level of confidence in the toxicological data. Nonetheless, even though the toxic effect of uranium cannot be predicted at low concentrations, uranium does exceed the RfD and should be considered a potential health problem at the Old Rifle site.

Potential exposures to molybdenum at the Old Rifle site (Figure 6.1) indicate that nearly 21 percent of the potential exposures exceed the EPA oral RfD of $0.005 \mathrm{mg} / \mathrm{kg}$-day. Approximately 7 percent of the potential exposures fall above the level where mild toxicity is expected $(0.008$ to $0.022 \mathrm{mg} / \mathrm{kg}$-day). The additional contribution expected from other sources would result in a greater percentage of the predicted exposures reaching this mild toxicity range. That toxicity would be manifested largely as increased copper excretion leading to copper deficiency, resulting in mild-to-severe anemia. Intakes as high as the uppermost tail of the distribution still would not reach severe toxicity levels that would cause gout. 


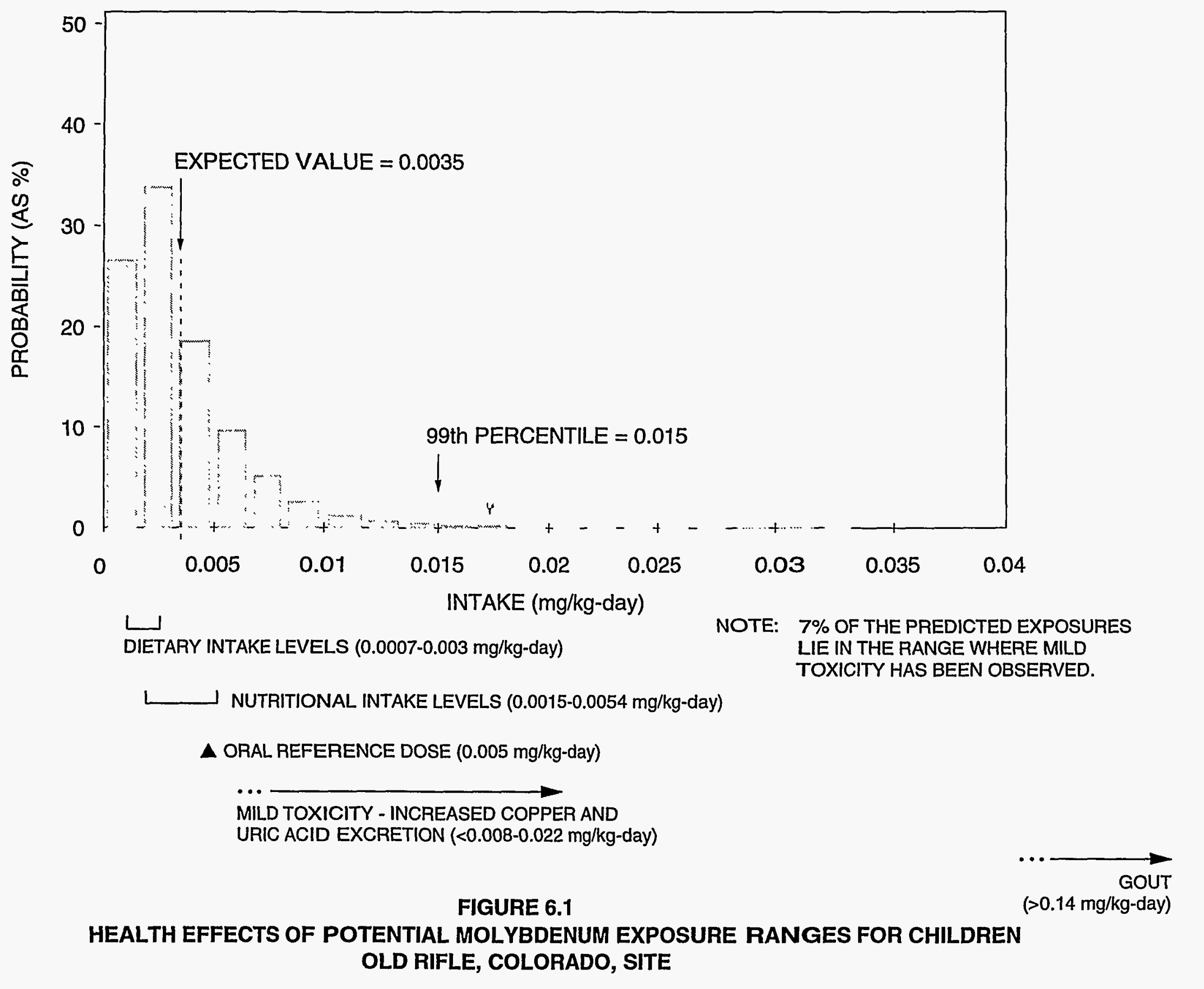




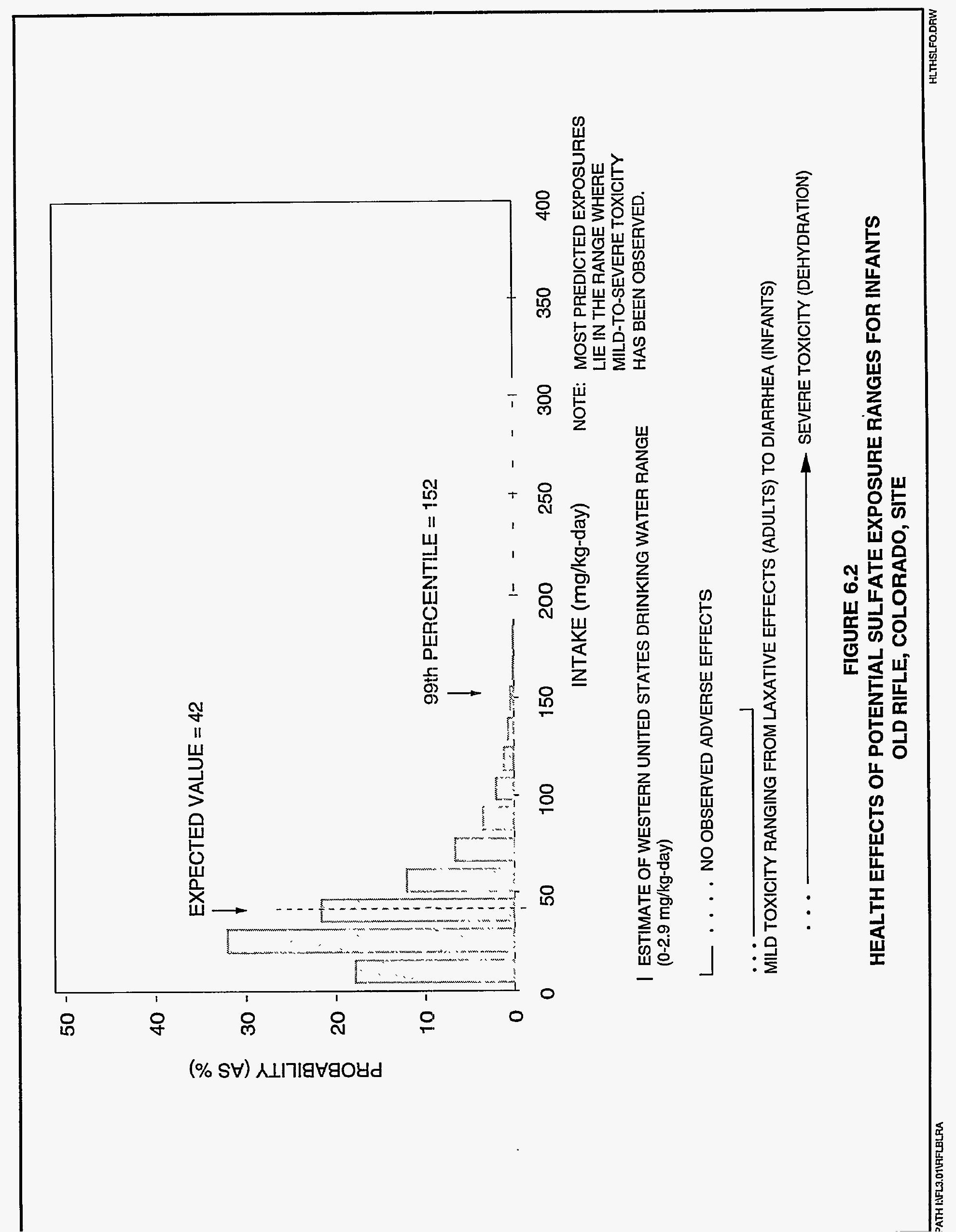




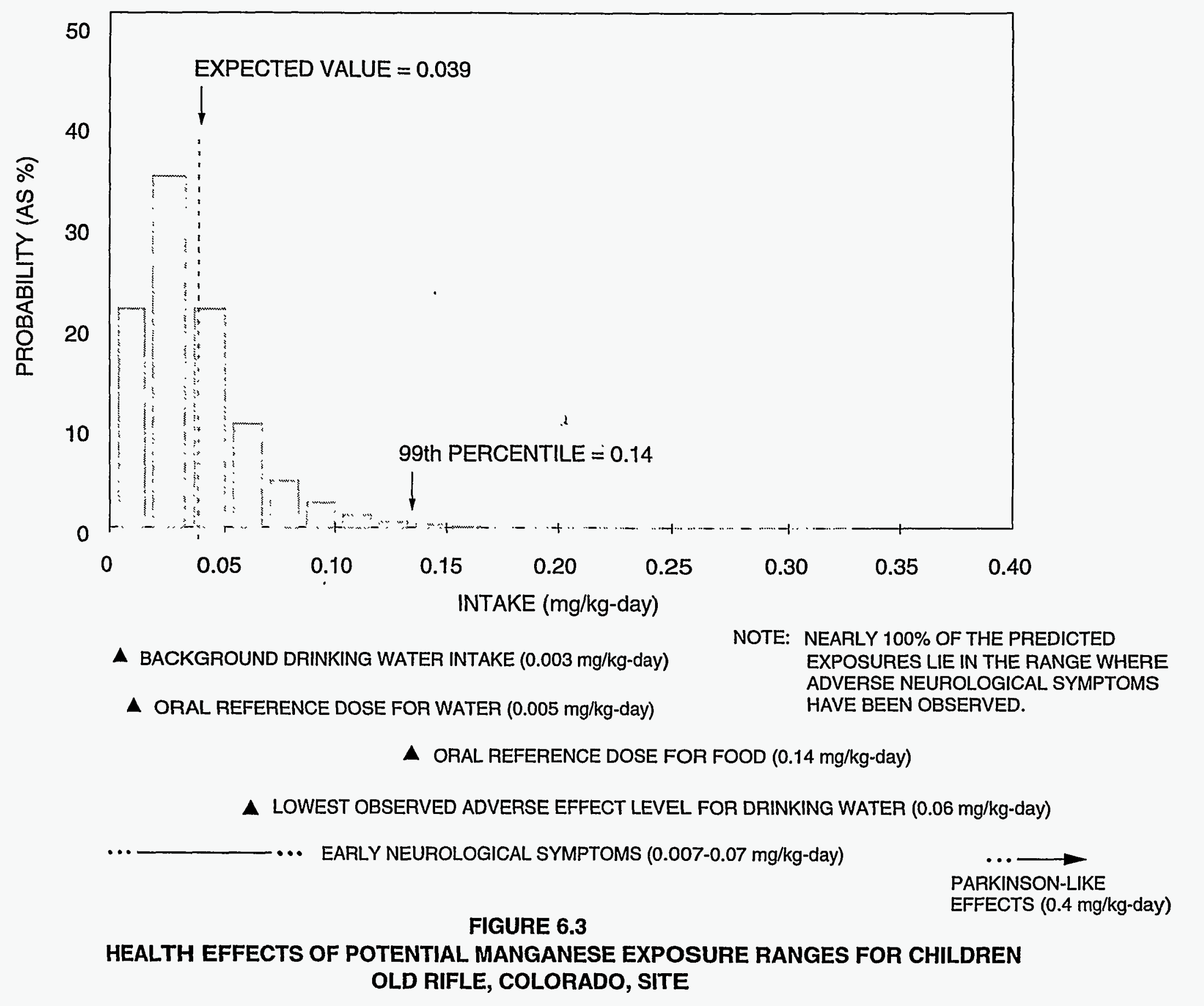




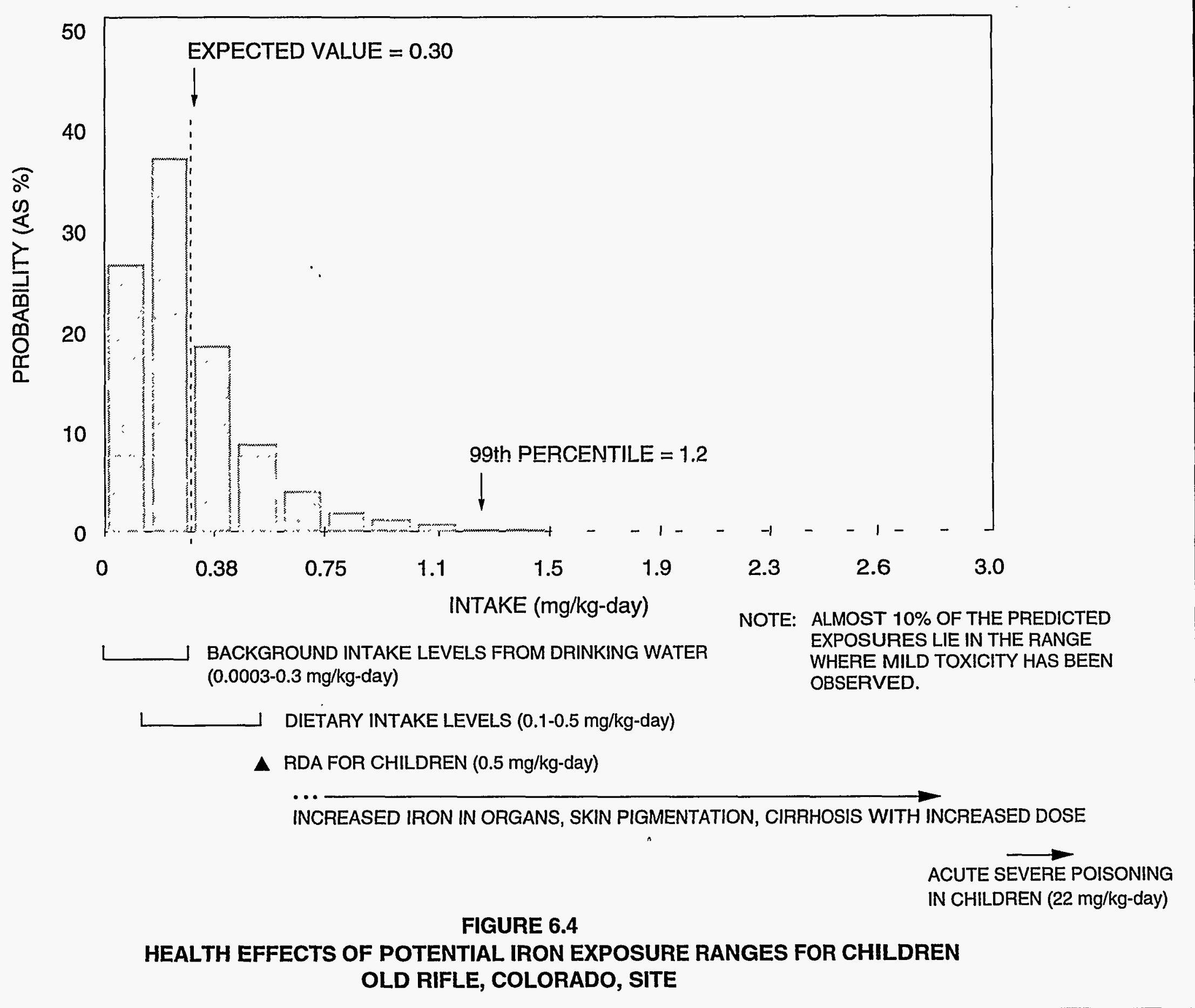




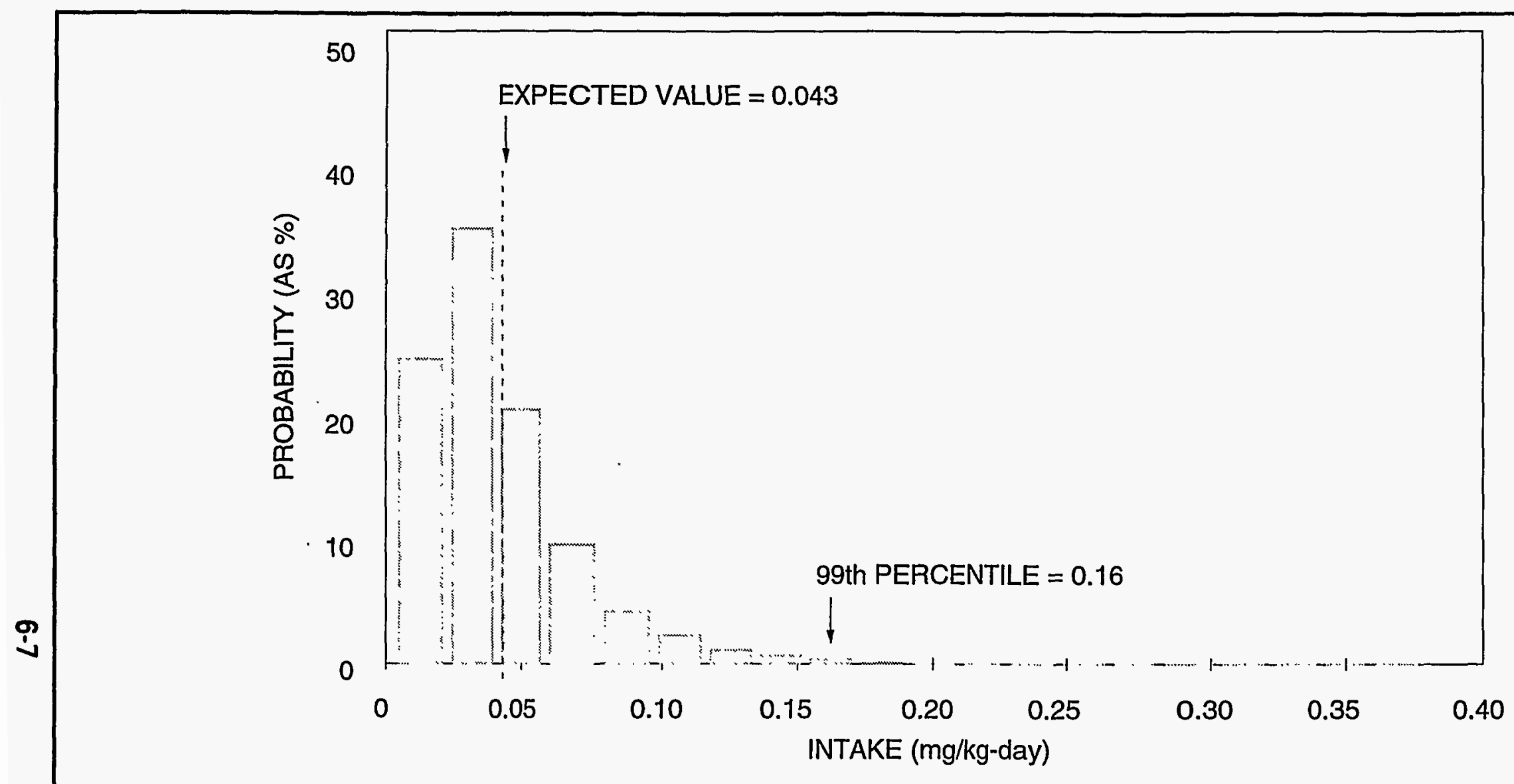

$\triangle$ ORAL REFERENCE DOSE (food and drinking water)(0.06 mg/kg-day)

... ــ SAFE INTACKE LEVELS FROM DRINKING WATER FOR CHILDREN (0.04 mg/kg-day)

I AVERAGE DIETARY INTAKE LEVELS FROM FOOD (0.01 $\mathrm{mg} / \mathrm{kg}$-day)

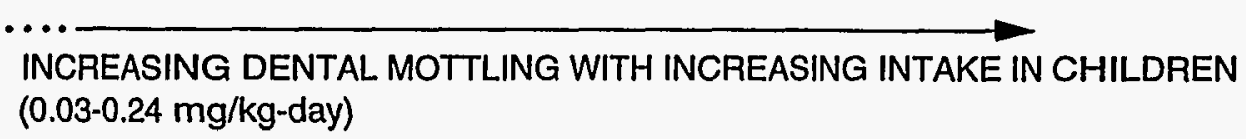

NOTE: $59 \%$ OF THE PREDICTED EXPOSURES LIE IN THE RANGE WHERE DENTAL MOTTLING HAS BEEN OBSERVED.

CRIPPLING SKELETAL FLUOROSIS IN ADULTS (0.29-1.1 $\mathrm{mg} / \mathrm{kg}$-day for $10-20$ years)

\section{FIGURE 6.5}

HEALTH EFFECTS OF POTENTIAL FLUORIDE EXPOSURE RANGES FOR CHILDREN OLD RIFLE, COLORADO, SITE 
Figure 6.2 shows that at the expected intake value of $42 \mathrm{mg} / \mathrm{kg}$-day for sulfate, mild-to-severe toxicity could be expected. At least some of the predicted exposures could severely affect infants. Mild toxicity in the form of laxative effects would be expected in adults. Severe effects in infants would be as dehydration due to chronic diarrhea.

Ninety-nine percent of the potential exposures to manganese exceed the EPA oral RfD of $0.005 \mathrm{mg} / \mathrm{kg}$-day (Figure 6.3). Fifteen percent of the possible exposures are greater than the LOAEL for drinking water and mild toxicity may occur at these exposures levels. However, the dietary intake of manganese from food is known to reach up to $0.13 \mathrm{mg} / \mathrm{kg}$-day. The additional contribution expected from background dietary intake or other sources would increase exposure. Predicted intake levels are considerably less than those known to cause severe toxic effects such as Parkinson-like effects, but some of the exposures are above levels where neurological symptoms occur. Therefore, incremental sources likely would result in mild toxicity manifested as adverse neurological symptoms.

Thirty-six percent of the distribution of potential exposures to iron is within a range of background intake levels, and up to 86 percent is within the dietary levels for children of approximately 0.1 to $0.5 \mathrm{mg} / \mathrm{kg}$-day (Figure 6.4). The recommended dietary allowarice for children of $0.5 \mathrm{mg} / \mathrm{kg}$-day is exceeded by 14 percent of the distribution. Five percent of the predicted iron intakes are above the dose where iron bioaccumulation into body organs and skin pigmentation would occur.

The intake distribution for fluoride shows 80 percent of the predicted intakes as below the EPA oral RfD of $0.06 \mathrm{mg} / \mathrm{kg}$-day (Figure 6.5). However, dental mottling has been observed at intakes as low as $0.03 \mathrm{mg} / \mathrm{kg}$-day and 59 percent of the predicted exposures lie above this range. Toxic effects from exposure to fluoride are expected to increase with increased dose. None of the potential intake levels lie in the range where severe toxicity is expected.

None of the exposure doses calculated in Section 4.2 for the pathways other than ground water ingestion (i.e., ground water dermal contact, surface water and sediment ingestion and dermal contact, and fish ingestion) would alter the evaluation of potential adverse health effects from the contaminants of potential concern at the Old Rifle site if the exposure doses were added to the ground water ingestion exposure dose. Additionally, the exposures calculated for these pathways would not be expected to cause adverse health effects if they were the only source of exposure.

\section{Potential noncarcinogenic health effects - New Rifle}

Intake distributions for the contaminants of potential concern in the alluvial aquifer were simulated for the New Rifle site. These constituents are ammonium, arsenic, cadmium, chloride, fluoride, iron, manganese, molybdenum, 
selenium, sodium, uranium, vanadium, nitrate, and sulfate. Figures 6.6 through 6.17 present intake distributions for arsenic, manganese, nitrate, selenium, molybdenum, sulfate, sodium, chloride, fluoride, iron, vanadium, and ammonium and the possible adverse health effects relative to dose levels.

The exposure intakes generated for cadmium were determined to be at a level where toxic effects are not expected. Therefore, the exposure distribution for cadmium is not presented in this risk assessment. The exposure distribution for uranium is not presented although uranium could pose a health problem at New Rifle. Approximately 94 percent of the exposure distribution for uranium at New Rifle exceeds the toxicity value (RfD) where adverse health effects could occur. However, adverse health effects have not been observed for cadmium at low concentrations (such as those detected at New Rifle). This discrepancy occurs largely because the toxicological database for uranium is incomplete and this uncertainty is considered in the EPA acceptable intake level (i.e., the RfD). Although low intake levels have not been associated with adverse health effects in humans or test animals, it is significant that most of the exposure distribution falls above the RfD criterion. This is because of the low level of confidence in the toxicological data. Nonetheless, even though the toxic effect of uranium cannot be predicted at low concentrations, uranium does exceed the RfD and should be considered a potential health problem at New Rifle site.

Based on historical water quality data, antimony and lead were considered contaminants of potential concern at the New Rifle site. These contaminants have been detected infrequently (less than 12 percent of the time), and analytical data indicate concentrations of these constituents are decreasing over time. Therefore, distributions of potential intakes for antimony and lead were not simulated but were evaluated using the maximum detected concentrations to estimate a single maximum potential exposure dose. Table 6.1 compares these maximum exposure doses to relevant toxicity data.

The calculated exposure dose $(0.001 \mathrm{mg} / \mathrm{kg}$-day) for antimony falls below the LOAEL observed for this constituent in rats $(0.35 \mathrm{mg} / \mathrm{kg}$-day). Acute symptoms after oral ingestion of antimony have been observed in humans (gastrointestinal distress, including stomach pains, colic, nausea, and vomiting). No data are available to describe chronic effects that could be associated with oral ingestion of antimony. However, antimony exceeds its RfD $(0.0004 \mathrm{mg} / \mathrm{kg}$-day), indicating that chronic exposure to antimony at the maximum detected concentration could cause adverse health problems. However, adverse effects have not been observed at low levels (such as those detected at the New Rifle site), and it was detected infrequently. Therefore, even though antimony exceeds its RfD, adverse human health effects would not be expected with ground water ingestion at this site because it was detected infrequently.

Lead was also detected infrequently at the New Rifle site. Toxicity values for lead are still under review by the EPA; therefore, the calculated exposure dose 

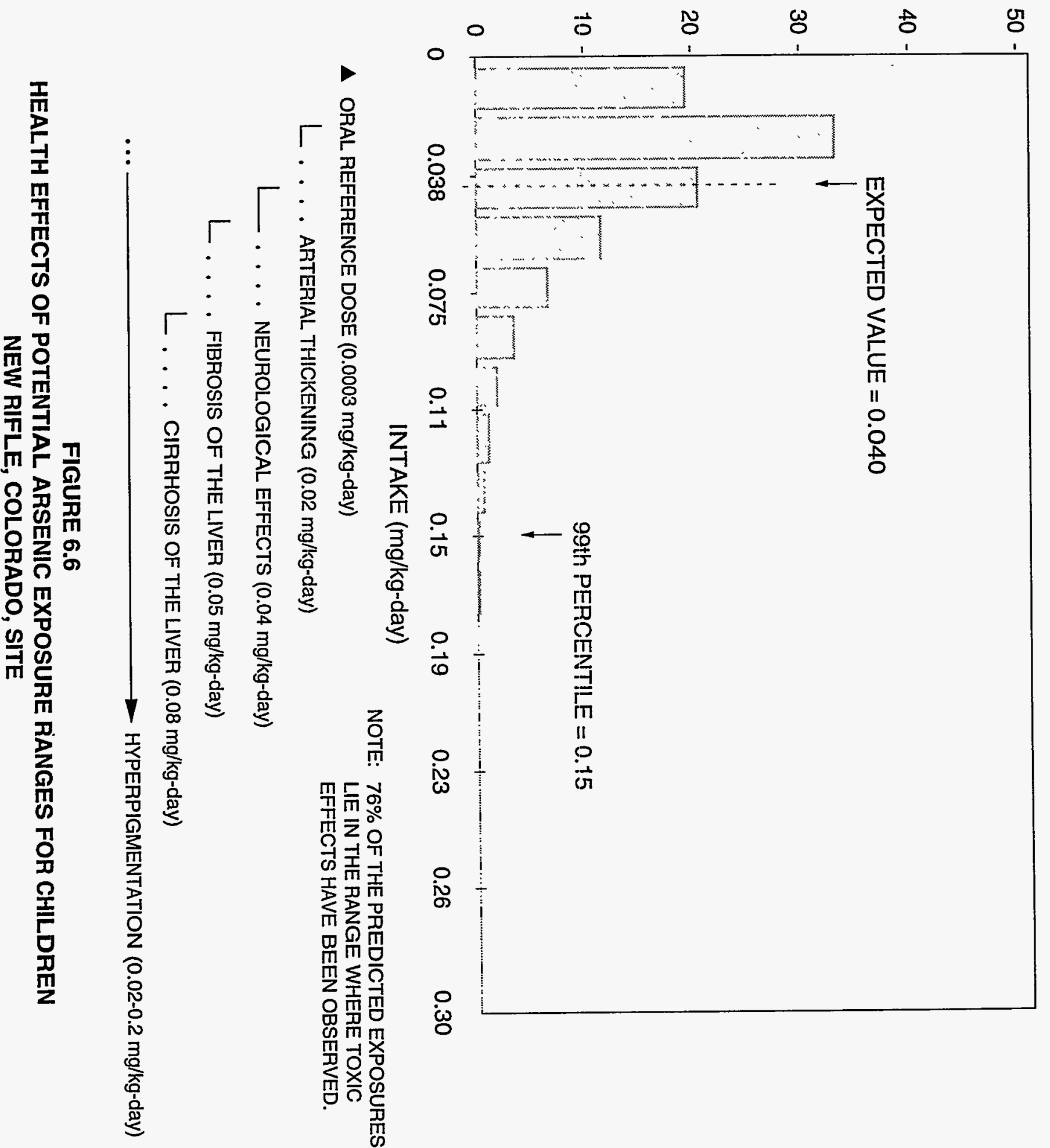

- 而

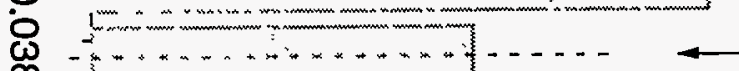

II

กุก

(

0

O

(n)

齐

m<smiles>[CH]1CCCCC1</smiles>

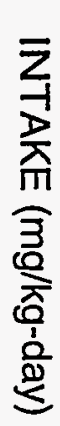

1

$+$

N $\leq$

高

高 $\frac{0}{3} \stackrel{0}{\frac{c}{0}}$

을

กᄁᄁำ oै

ग11

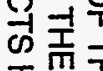

工而章

而之品

๓⿴囗十

$m \sum \frac{\Omega}{2}$

임ํㄱ

觉 $\mathrm{m}$

肾甫爻

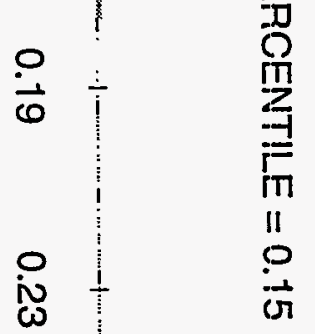

感 


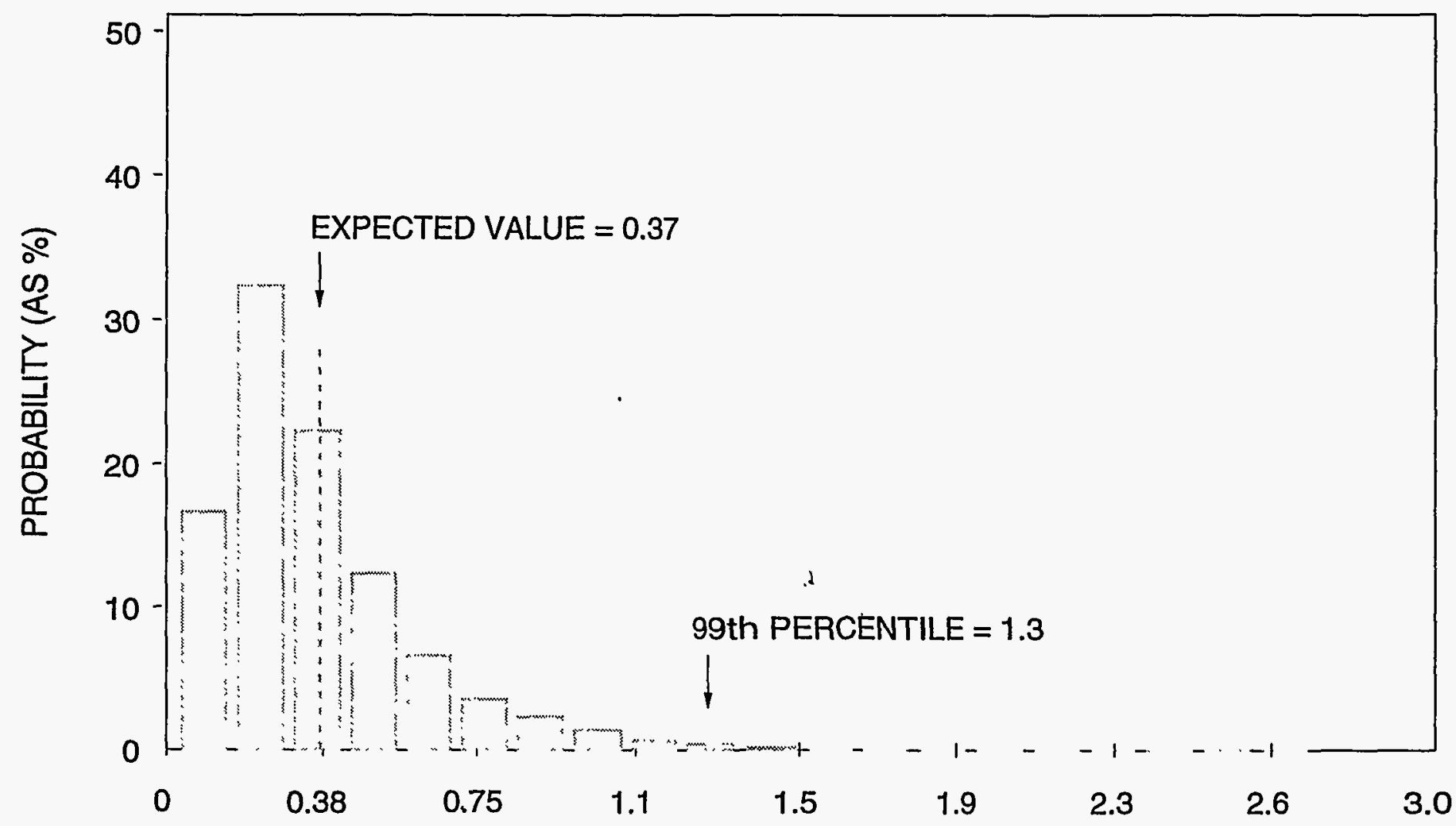

INTAKE (mg/kg-day)

$\triangle$ BACKGROUND DRINKING WATER INTAKE (0.003 mg/kg-day)

$ـ$ DIETARY INTAKE FROM FOOD (0.03-0.13 mg/kg-day)

NOTE: $100 \%$ OF THE PREDICTED EXPOSURES LIE IN THE RANGE WHERE ADVERSE NEUROLOGICAL EFFECTS HAVE BEEN OBSERVED.

$\triangle$ ORAL REFERENCE DOSE (0.005 mg/kg-day)

$\ldots \rightarrow$ EARLY NEUROLOGICAL SYMPTOMS (0.002 mg/kg-day)

PARKINSON-LIKE EFFECT $(0.4 \mathrm{mg} / \mathrm{kg}$-day)

FIGURE 6.7

HEALTH EFFECTS OF POTENTIAL MANGANESE EXPOSURE RANGES FOR CHILDREN NEW RIFLE, COLORADO, SITE 


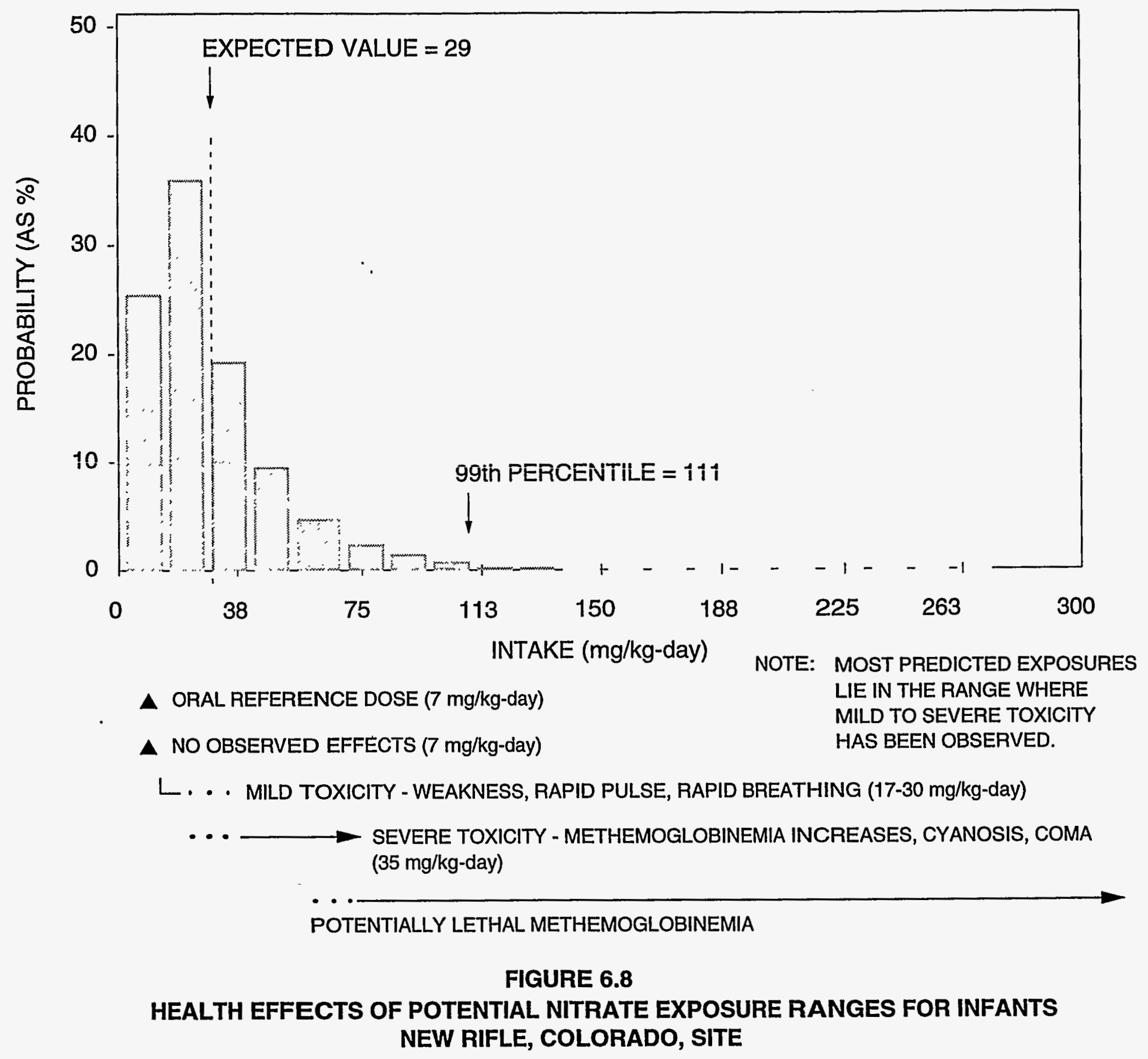




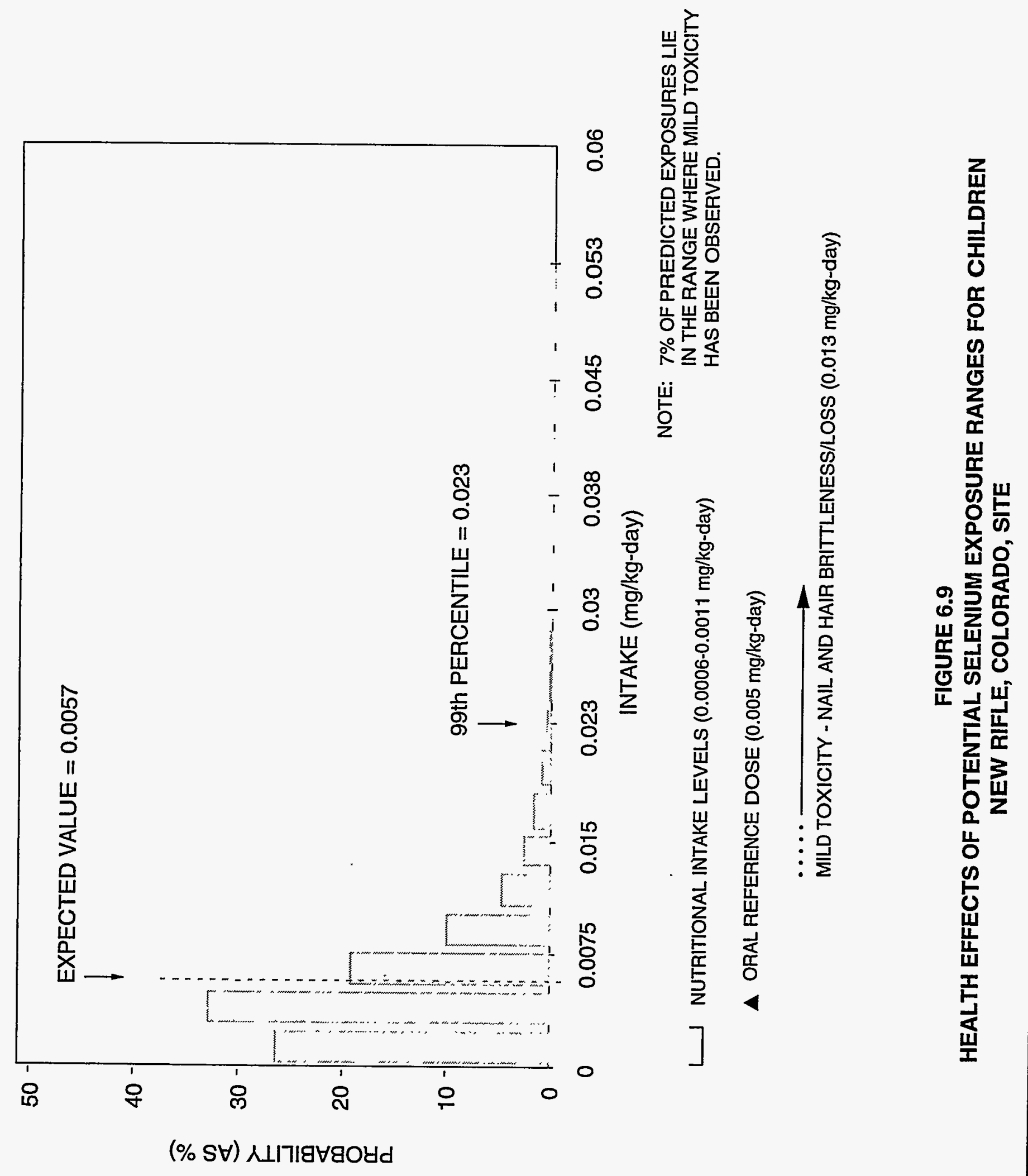




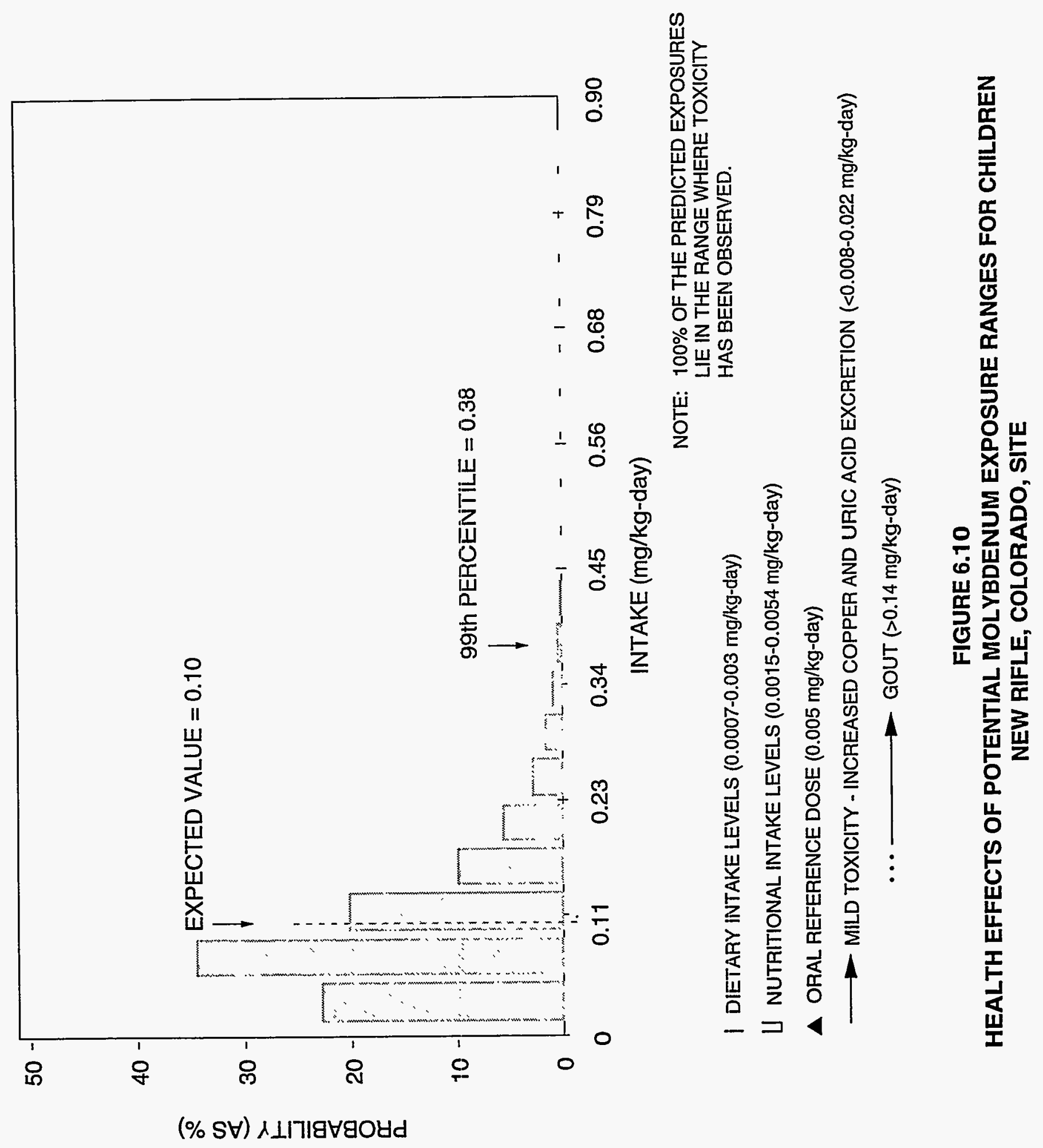




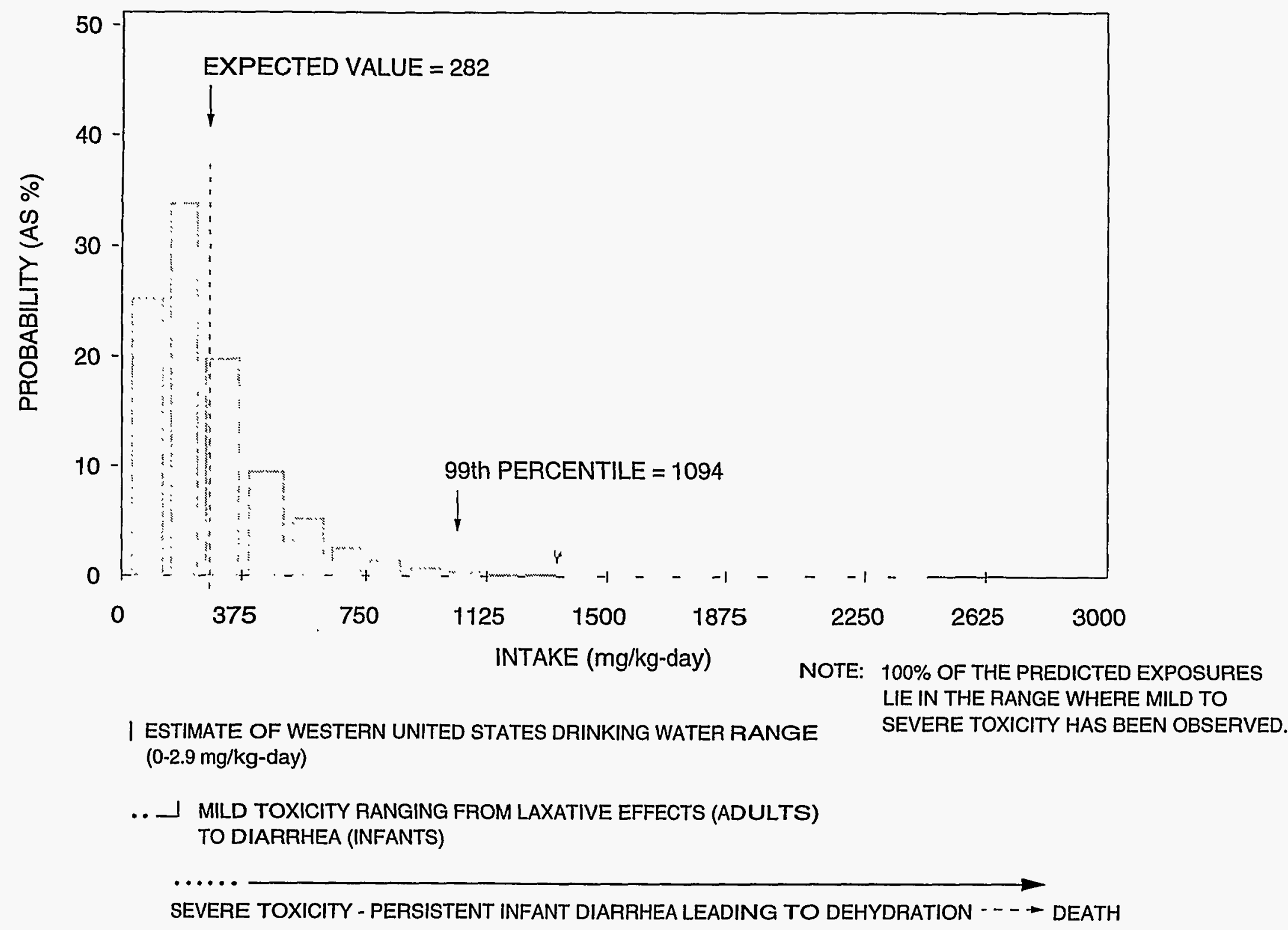

FIGURE 6.11

HEALTH EFFECTS OF POTENTIAL SULFATE EXPOSURE RANGES FOR INFANTS NEW RIFLE, COLORADO, SITE 


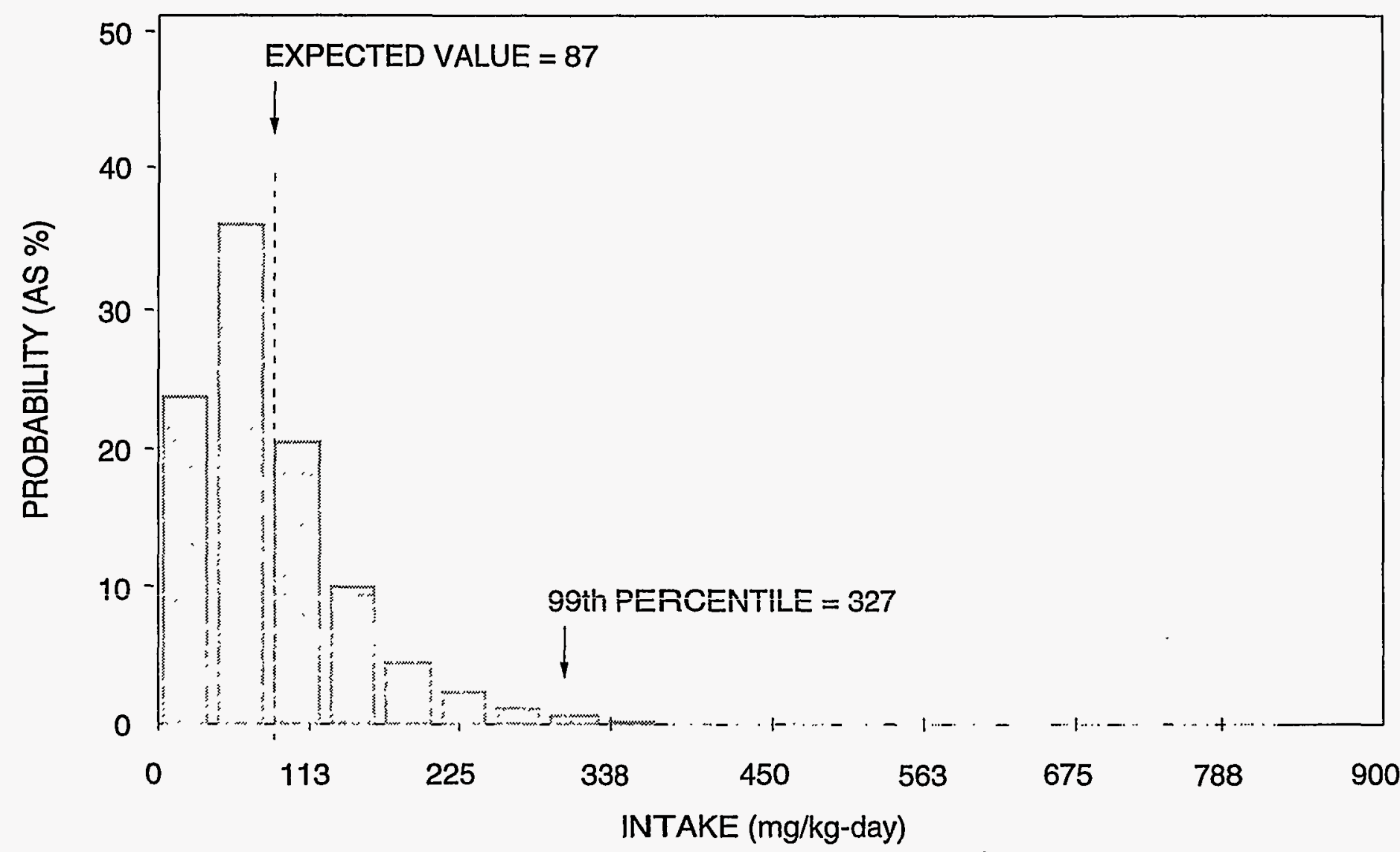

NOTE: $94 \%$ OF THE PREDICTED EXPOSURES LIE IN THE RANGE WHERE HYPERTENSION HAS BEEN OBSERVED.

BACKGROUND INTAKE
$(<0.03-11 \mathrm{mg} / \mathrm{kg}$-day)

I NUTRITIONAL REQUIREMENT (1.6 mg/kg-day)

$\triangle$ NRC RECOMMENDED LIMIT FOR DIETARY REQUIREMENT (<34 mg/kg-day)

... - ... ESTIMATED DIETARY INTAKE LEVELS (57-85 mg/kg-day)

HYPERTENSION MAY OCCUR (23 mg/kg-day)

FIGURE 6.12

HEALTH EFFECTS OF POTENTIAL SODIUM EXPOSURE RANGES FOR CHILDREN NEW RIFLE, COLORADO, SITE 


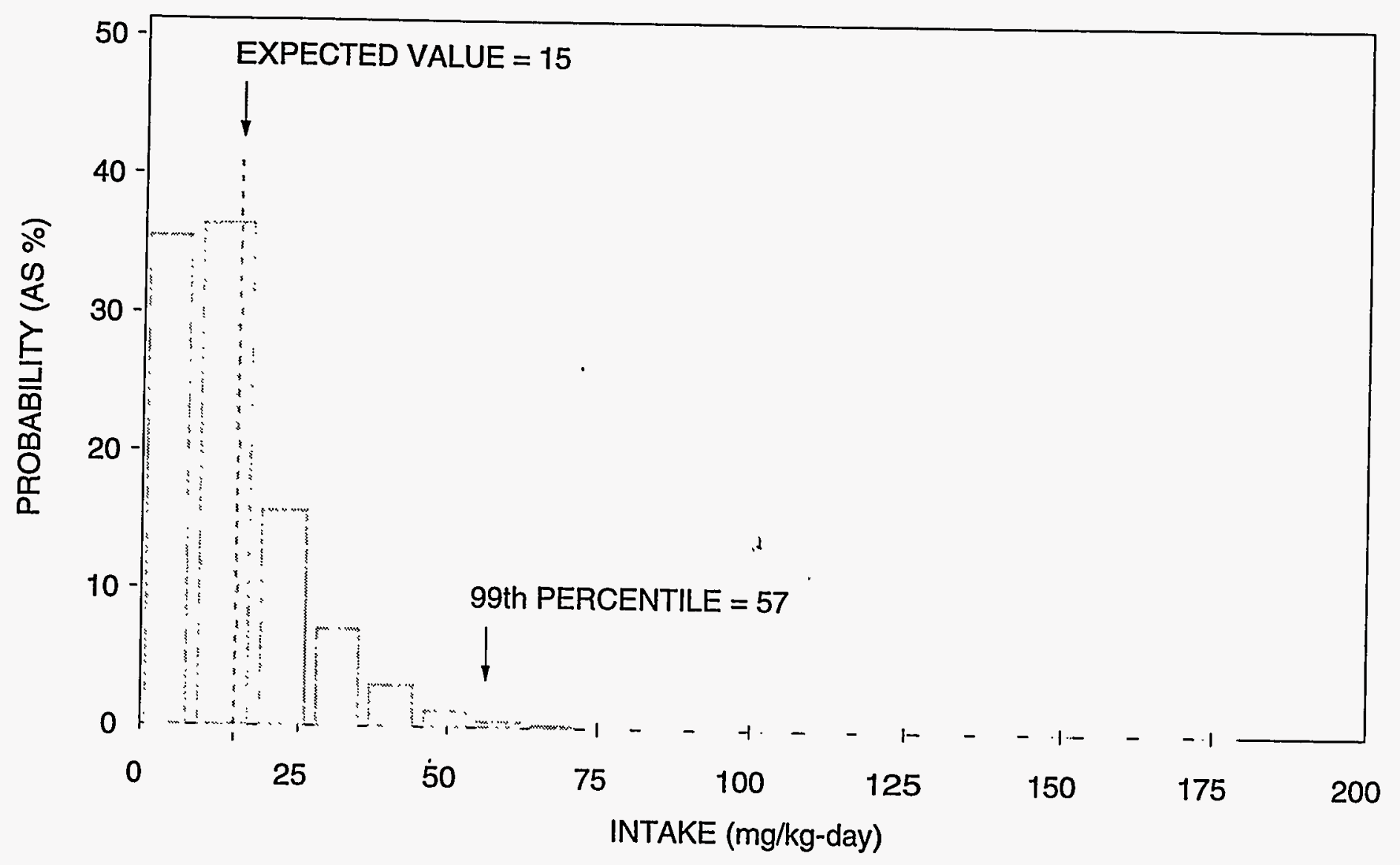

I INTAKE FROM DRINKING WATER (0.6 mg/kg-day)

NOTE: $6 \%$ OF THE PREDICTED EXPOSURES LIE IN THE RANGE WHERE HYPERTENSION HAS BEEN OBSERVED.

$\triangle$ RECOMMENDED INTAKE LIMIT FROM DRINKING WATER (7 mg/kg-day)

HYPERTENSION IN HUMANS (ESTIMATED $36-180 \mathrm{mg} / \mathrm{kg}$-day)

FIGURE 6.13

HEALTH EFFECTS OF POTENTIAL CHLORIDE EXPOSURE RANGES FOR CHILDREN NEW RIFLE, COLORADO, SITE 


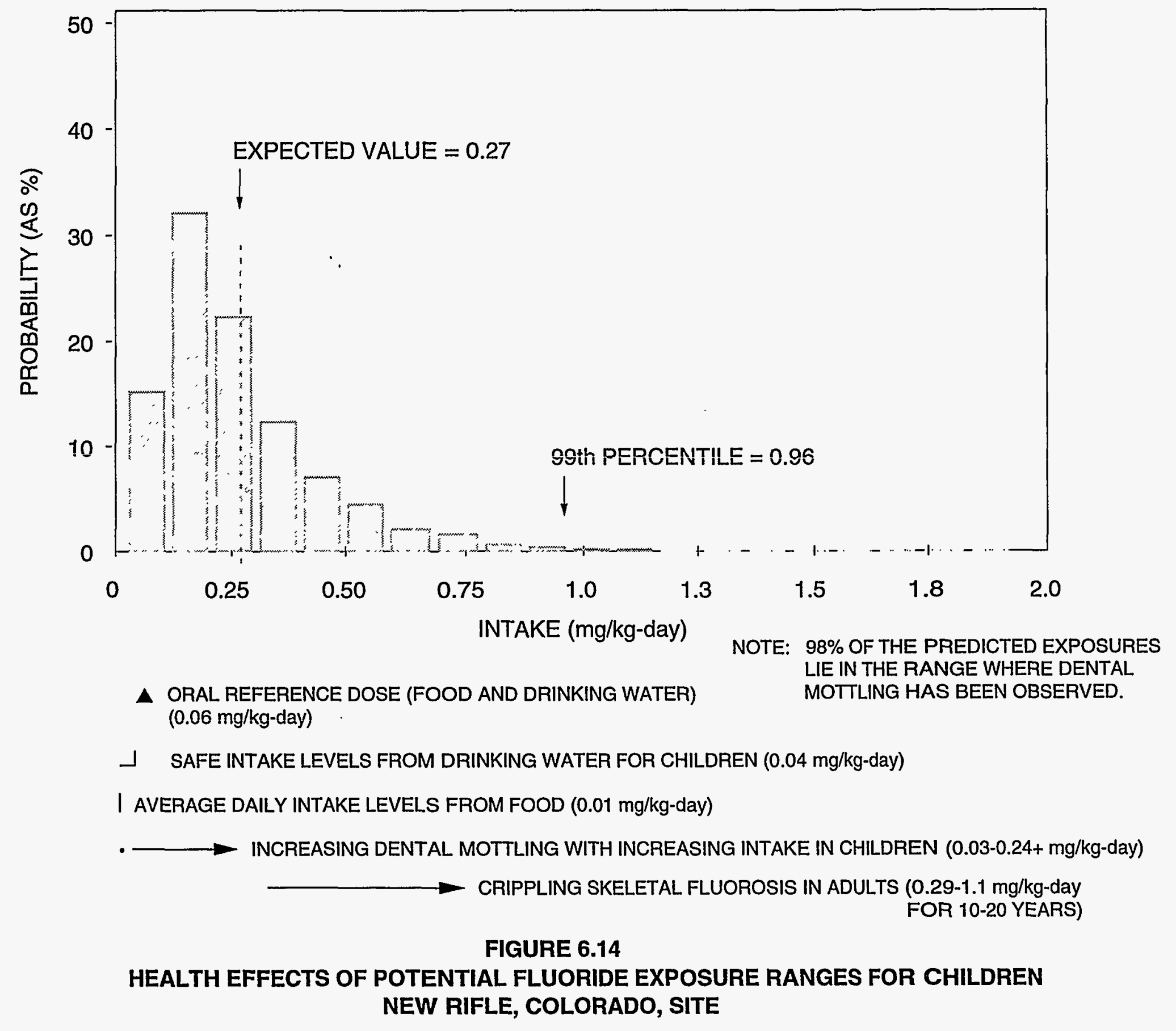




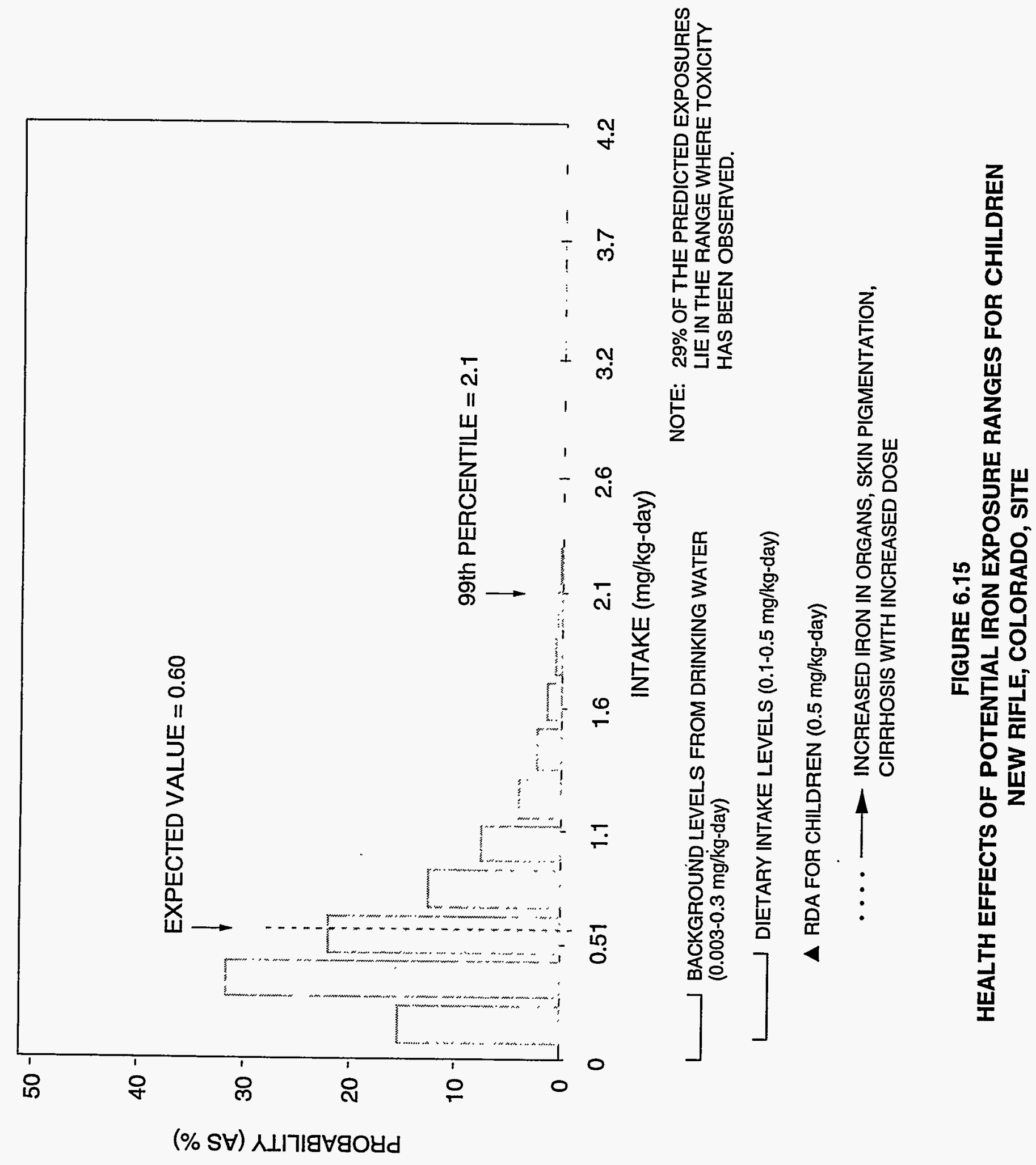




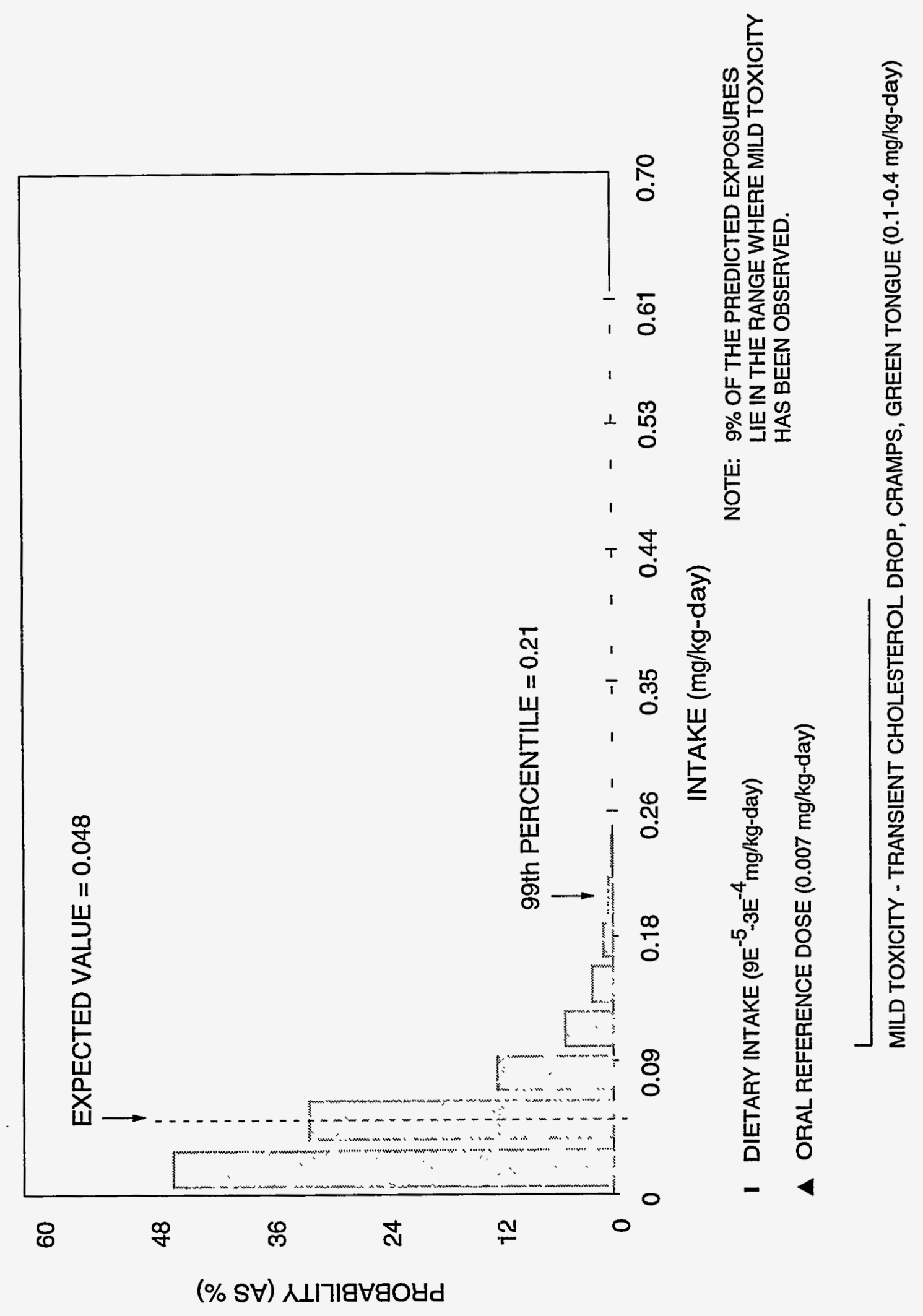




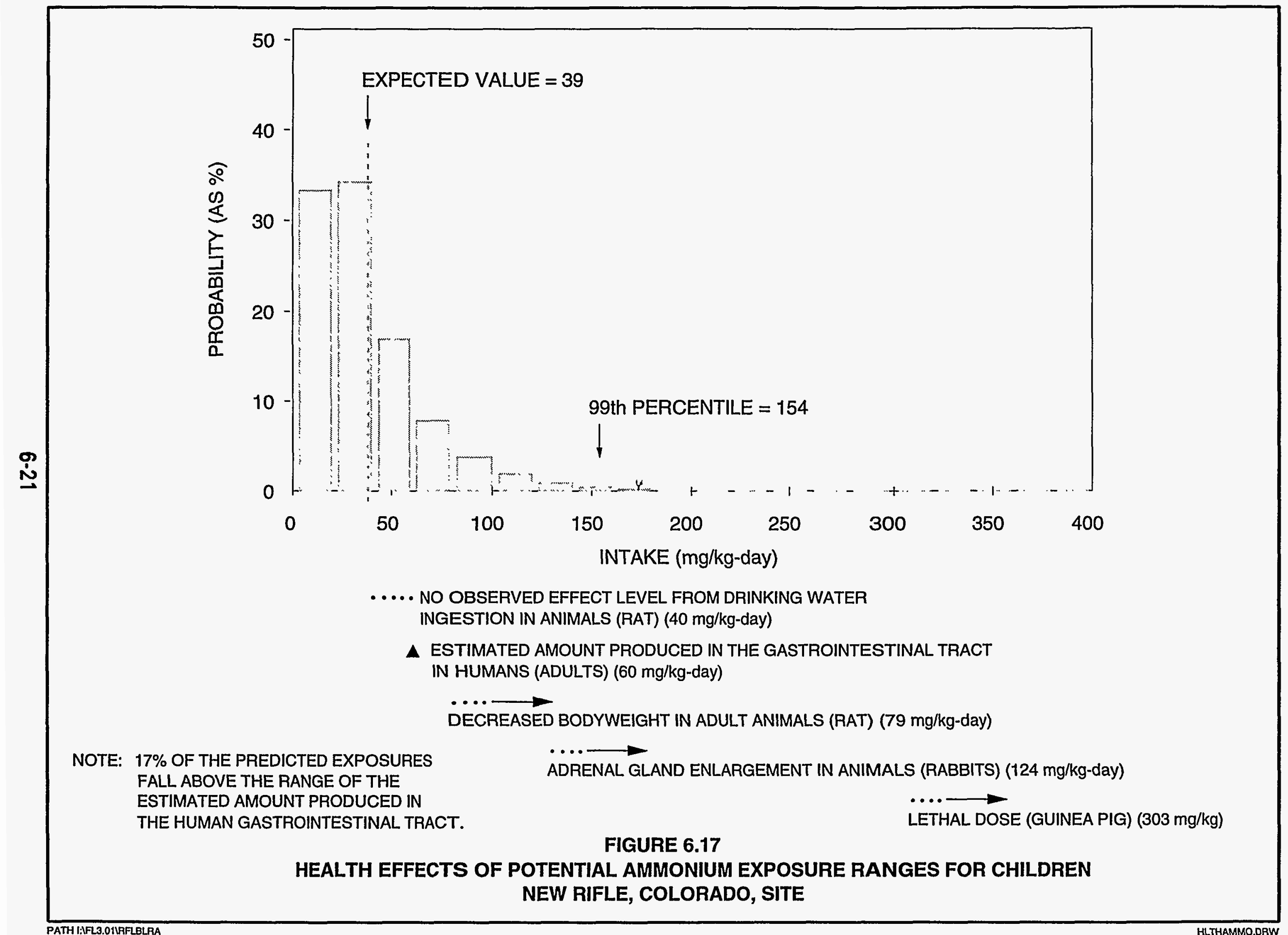


Table 6.1 Risk evaluation of antimony and lead detected in the alluvium at the New Rifle, Colorado, site

\begin{tabular}{lccccc}
\hline $\begin{array}{c}\text { Contaminant } \\
\text { of potential } \\
\text { concern }\end{array}$ & $\begin{array}{c}\text { Exposure } \\
\text { concentration } \\
\text { (mg/L) }\end{array}$ & $\begin{array}{c}\text { Exposure } \\
\text { dose } \\
\text { (mg/kg-day) }\end{array}$ & $\begin{array}{c}\text { LOAEL } \\
\text { (mg/kg-day) }\end{array}$ & $\begin{array}{c}\text { Nature of the effect } \\
\text { caused by the LOAEL }\end{array}$ & $\begin{array}{c}\text { RfD }^{c} \\
\text { (mg/kg-day) }\end{array}$ \\
\hline $\begin{array}{llllll}\text { Mill tailings area } \\
\text { Antimony }\end{array} 0.038$ & 0.001 & 0.35 & $\begin{array}{l}\text { Acute symptoms of } \\
\text { gastrointestinal distress }\end{array}$ & 0.0004 \\
Lead & 0.08 & ND & $\begin{array}{l}\text { No safe level has been } \\
\text { demonstrated for the } \\
\text { most sensitive effects of } \\
\text { lead exposure in humans } \\
\text { (i.e., heme synthesis, } \\
\text { erythropoiesis, and } \\
\text { neurobehavioral toxicity) }\end{array}$ \\
\hline
\end{tabular}

The maximum observed concentration in ground water from the most contaminated wells.

${ }^{b}$ Calculated for an adult using the ground water ingestion equation on Table 4.1 where the contaminant concentration in ground water is represented by the maximum observed concentration in the most contaminated wells; the ingestion rate $=2 \mathrm{~L}$ per day; the exposure frequency $=350$ days per year; the exposure duration $=30$ years; body weight $=70 \mathrm{~kg}$; and the averaging time $=265$ days $\times 30$ years.

'The basis for oral RfD is presented in Table 5.1 .

ND - not determined. 
cannot be evaluated against toxicity values. However, the toxic effects of lead exposure are well documented (see Section 5.01, although exposure doses associated with these effects are not well known. Therefore, a safe level of lead ingestion has not been demonstrated for the most sensitive effects of lead exposure in humans (Table 6.1).

Potential exposures to arsenic at the New Rifle site presented in Figure 6.6 indicate that nearly all potential exposures exceed the EPA oral RfD of $0.0003 \mathrm{mg} / \mathrm{kg}$-day. At the expected value of $0.04 \mathrm{mg} / \mathrm{kg}$-day, 38 percent of the distribution is above this dose where neurological effects are expected to occur. Increasing intakes leading to possible severe toxicity manifested as fibrosis or cirrhosis of the liver are also possible.

All (100 percent) predicted manganese exposures exceed the dose where early neurological symptoms that could lead to Parkinson-like effects have been observed (Figure 6.7). The entire intake distribution, with an expected value of $0.37 \mathrm{mg} / \mathrm{kg}$-day, exceeds the EPA oral RfD of $0.005 \mathrm{mg} / \mathrm{kg}$-day by several orders of magnitude. Although dietary intakes of manganese range from 0.03 to $0.13 \mathrm{mg} / \mathrm{kg}$-day, the incremental dose would not alter the predicted adverse health effects.

At the predicted nitrate intake levels (Figure 6.8), toxic effects could be expected. Twenty-eight percent of the predicted nitrate exposures could result in severe toxicity to infants. Four percent of the predicted exposures are above $75 \mathrm{mg} / \mathrm{kg}$-day where lethal methemoglobinemia in infants is expected to occur. However, lethal methemoglobinemia has been observed at intakes just over $35 \mathrm{mg} / \mathrm{kg}$-day.

Mild toxicity, manifested as nail and hair brittleness/loss, could be expected for 7 percent of the selenium exposures (Figure 6.9). Forty-three percent of the possible selenium intakes are above the EPA oral RfD of $0.005 \mathrm{mg} / \mathrm{kg}$-day but most of the predicted intakes (93 percent) lie in the range where adverse health effects have not been observed. Recommended nutritional intakes for selenium range from 0.0006 to $0.0011 \mathrm{mg} / \mathrm{kg}$-day, and 95 percent of the distribution falls above this range. Therefore, contributions from the necessary dietary intake probably would not increase the dose enough to reach levels of adverse health effects. However, because a large percentage of the distribution lies above the RfD, the potential for adverse health effects cannot be disregarded.

Potential exposures to molybdenum at the site (Figure 6.10), indicate that all potential exposures exceed the EPA oral RfD of $0.005 \mathrm{mg} / \mathrm{kg}$-day. Nearly all of the potential exposure distribution falls above intakes that would cause mild toxicity. Toxicity would manifest in metabolic impacts that decrease copper excretion, leading to mild-to-severe anemia. Toxic effects from molybdenum ingestion at a high dose $(0.14 \mathrm{mg} / \mathrm{kg}$-day) can lead to the manifestation of gout.

Sulfate toxicity is related to the potential dehydration produced by its laxative effects. Levels predicted for the New Rifle site would be expected to cause 
mild toxicity in adults (Figure 6.11). Infants are more sensitive to these toxic effects and chronic ingestion of high-sulfate water can be lethal if irreversible dehydration occurs. Thirty seven percent of the predicted exposures for infants lie in the range where severe toxicity has been observed lless than $282 \mathrm{mg} / \mathrm{kg}$ day).

Ingestion of excessive sodium is associated with hypertension in adults and children at intakes near $23 \mathrm{~m} \mathrm{~g} / \mathrm{kg}$-day. Ninety-four percent of the predicted exposures for children are in this range where the development of hypertension may occur (Figure 6.12). Although the average dietary intake of sodium is 57 to $85 \mathrm{mg} / \mathrm{kg}$-day and approximately 60 percent of the distribution is below this exposure, the incremental exposure to sodium from contaminated ground water could result in exposures in the range where more severe toxicity occurs.

The hypertensive effects of chloride and sodium are similar although in comparison, the risk of hypertension from the predicted sodium exposures at New Rifle would significantly outweigh the risk of hypertension from the predicted chloride exposures. Six percent of the potential chloride exposures is in the range where hypertension has been observed (chronic intakes of $36 \mathrm{mg} / \mathrm{kg}$-day or more) (Figure 6.13). Nearly 76 percent of the distribution of chloride exposures is above the recommended daily intake of $7 \mathrm{mg} / \mathrm{kg}$-day.

Dental mottling increases with increased fluoride intake beginning at $0.03 \mathrm{mg} / \mathrm{kg}$-day. Nearly 100 percent of the intakes estimated for fluoride are above the level where mild toxicity can occur. Although 37 percent of the predicted exposures for children lie in the range of documented severe toxicity in adults, data on this toxic effect in children are not available; crippling skeletal fluorosis in adults can manifest at $0.29 \mathrm{mg} / \mathrm{kg}$-day with chronic ingestion for 10 years or more. Toxicity is not observed in children at this level and approximately 75 percent of the predicted exposures are below $0.4 \mathrm{mg} / \mathrm{kg}$-day. This level has been identified as a safe drinking water intake level for children (Figure 6.14).

Approximately half the predicted iron exposures are in the range of background intake levels from drinking water and known dietary intake levels (Figure 6.15). Approximately $\mathbf{3 0}$ percent of the predicted exposures lie in the range known to cause iron bioaccumulation in organs and skin pigmentation; increased dosage $10.7 \mathrm{mg} / \mathrm{kg}$-day and above) leads to more severe toxic effects such as cirrhosis of the liver.

Almost all predicted vanadium intakes fall above the known dietary intake range of 0.00009 to $0.0003 \mathrm{mg} / \mathrm{kg}$-day and the EPA oral RfD of $0.007 \mathrm{mg} / \mathrm{kg}$-day (Figure 6.16). However, toxic effects from vanadium exposures have been observed only at levels above $0.1 \mathrm{mg} / \mathrm{kg}$-day. Approximately 9 percent of the predicted intakes are abov: this level. Metabolic impacts manifested as sudden drops in cholesterol levels and a green tongue could occur at doses above 0.1 $\mathrm{mg} / \mathrm{kg}$-day. 
Mild-to-severe toxicity has been observed in laboratory animals with intakes of ammonium compounds in the range above the mean intake predicted for the New Rifle site at $39 \mathrm{mg} / \mathrm{kg}$-day (Figure 6.17).

None of the exposure doses calculated in Section 4.2 for the pathways other than ground water ingestion (i.e., ground water dermal contact, surface water and sediment ingestion and dermal contact, and fish ingestion) would alter the evaluation of potential adverse health effects from the contaminants of potential concern at the New Rifle site if the exposure doses were added to the ground water ingestion exposure dose. Additionally, the exposures calculated for these pathways would not be expected to cause adverse health effects if they were the only source of exposure.

\subsection{POTENTIAL FUTURE CARCINOGENIC RISKS}

Potential future cancer risk at the Old and New Rifle sites is evaluated for both radiological and chemical carcinogens identified as contaminants of potential concern at both sites. Uranium and its decay products are the only radionuclide carcinogens identified as a contaminants of potential concern, and arsenic is the only chemical carcinogen identified as a contaminant of potential concern. Because no one is currently exposed to these potential carcinogens, all cancer risks are potential future risks that depend on using contaminated ground water as the primary drinking water source.

Chemical and radionuclide slope factors used for estimating cancer risks are not developed in the same manner mathematically, and their mechanisms of carcinogenicity are different. Therefore, cancer risks from radionuclides generally are not considered additive with cancer risks from chemical carcinogens and results are reported separately.

\section{Radionuclides}

Natural uranium has not been shown to cause cancer in humans or animals following ingestion. However, because uranium and all its decay products are radioactive, they are considered carcinogens. Because uranium contamination is attributed to the processing sites, the presence of its radioactive progeny is also considered site-related. Therefore, uranium and its longer-lived progeny, lead210, radium-226, polonium-210, and thorium-230, are included in the calculation of radiological cancer risk. All radionuclides are considered Class $A$ carcinogens (known human carcinogens).

This risk assessment calculates the excess (or increased) individual lifetime cancer risk for carcinogens. This risk level describes the increased likelihood that an individual will develop cancer as a result of continuous, lifetime exposure to a contaminant of potential concern. Because maximum concentrations are used to calculate carcinogenic risk, continuous lifetime exposure is unlikely at the Rifle sites because contaminant concentrations are expected to decrease over time. The carcinogenic risk level is presented as a probability, such as 
one-in-a-million chance (1E-06) that an individual will develop cancer. The acceptable EPA cancer risk range for carcinogens is $1 E-04$ (1 in 10,000) to 1E06 (1 in 1,000,000). This acceptable cancer range was promulgated in the final National Contingency Plan (NCP) (55 FR 8848). In the NCP 1E-06 is used to determine remediation goals when standards are not available or are not sufficiently protective because a site has multiple contaminants or multiple exposure pathways.

\section{Old Rifle}

Of the radionuclides evaluated at Old Rifle, uranium was the major contributor of potential carcinogenic risk. The risk estimate for uranium (2E-03) exceeds the acceptable risk range of $1 \mathrm{E}-\mathrm{C} 14$ to $1 \mathrm{E}-06$. Lead-210, radium-226, and polonium210 all fall within the acceptable risk range, and thorium-230 falls below the acceptable range ( 2 chances in 10,000,000). The total individual excess lifetime cancer risk is 2E-03 2 chances in 1000), which falls above the acceptable risk range.

\section{New Rifle}

Of the radionuclides evaluated at New Rifle, uranium was the major contributor of potential carcinogenic risk. The risk estimate for uranium 3E-04 (3 chances in 10,000) exceeds the acceptable risk range of 1E-04 to 1E-06. Lead-210, radium-226, polonium-210, and thorium-210 all fall within the acceptable risk range. The total individual excess lifetime cancer risk is 4E-04 (4 chances in $10,000)$, which falls above the acceptable risk range.

\section{Nonradiological}

Arsenic is the only chemical carcinogen detected above background at the Old and New Rifle sites. EPA is evaluating the carcinogenic potential of arsenic. However, excess cancer risk calculations were based on the EPA-derived slope factor of $1.8 \mathrm{mg} / \mathrm{kg}$-day for developing skin cancer. The slope factor for chemical carcinogens correlates estimated daily intakes directly to incremental cancer risk. Using the slope factor for chemical carcinogens results in a 95 percent UCL estimate of cancer risk at a single exposure point.

\section{Qld Rifle}

Using the maximum arsenic concentration detected at Old Rifle of $0.24 \mathrm{mg} / \mathrm{L}$, the individual excess lifetime cancer risk for arsenic was 5E-03, or 5 chances in 1000 of developing cancer (Table 6.2). This risk level exceeds the upper-bound, acceptable risk level of 1E-04 (1 chance in 10,000).

\section{New Rifle}

Using the maximum arsenic concentration detected at New Rifle $(1.3 \mathrm{mg} / \mathrm{L})$, the total individual excess lifetime cancer risk for arsenic was $4 \mathrm{E}-02$, or 4 chances 
Table 6.2 Individual excess lifetime cancer risk calculations for ground water ingestion by a hypothetical future adult resident, Rifle, Colorado, sites

\begin{tabular}{|c|c|c|c|c|c|c|c|}
\hline $\begin{array}{l}\text { Contaminant } \\
\text { of concern }\end{array}$ & \multicolumn{2}{|c|}{$\begin{array}{l}\text { Concentration in } \\
\text { ground water }\end{array}$} & $\begin{array}{r}\text { Groun } \\
\text { expos } \\
\text { Old Rifle } \\
\text { (pCi pe }\end{array}$ & $\begin{array}{l}\text { water } \\
\text { re dose } \\
\text { New Rifle } \\
\text { lifetime) }\end{array}$ & $\begin{array}{l}\text { Oral slope } \\
\text { factor } \\
\text { (pCi) }^{-1}\end{array}$ & \multicolumn{2}{|c|}{$\begin{array}{l}\text { Individual excess } \\
\text { lifetime cancer risk }\end{array}$} \\
\hline $\begin{array}{l}\text { Radiological } \\
\text { Lead-210 } \\
\text { Polonium-210 } \\
\text { Radium-226 } \\
\text { Thorium-230 } \\
\text { Uranium }^{c}\end{array}$ & $\begin{array}{c}4.5 \\
0.8 \\
\\
0.2 \\
1441\end{array}$ & $\begin{array}{c}4.6 \\
1.6 \\
\\
53 \\
254\end{array}$ & $\begin{array}{c}9.5 E+04 \\
1.7+04 \\
1.9 E+04 \\
4.2 E+03 \\
3.0 E+07\end{array}$ & $\begin{array}{l}9.7 E+04 \\
3.4 E+04 \\
67 E+04 \\
1.1 E+06 \\
5.3 E+06\end{array}$ & $\begin{array}{c}1.01 \text { E-09 } \\
3.26 E-10 \\
2.96 E-10 \\
3.75 E-11 \\
5.32 E-11 \\
\text { Total }\end{array}$ & $\begin{array}{l}1 E-04 \\
5 E-06 \\
6 E-06 \\
2 E-07 \\
2 E-03 \\
2 E-03\end{array}$ & $\begin{array}{l}1 E-04 \\
1 E-05 \\
2 E-05 \\
4 E-05 \\
3 E-04 \\
4 E-04\end{array}$ \\
\hline $\begin{array}{l}\text { Nonradiological } \\
\text { Arsenic }\end{array}$ & $0.24^{\prime}$ & (L) 1.3 & $\underset{3 E-03}{\mathbf{~} \mathbf{m g} / \mathbf{l}}$ & $\begin{array}{l}\text { g-day) } \\
2 E-02\end{array}$ & $\begin{array}{c}1.8 \\
\mathrm{mg} / \mathrm{kg} \text {-day }\end{array}$ & 5E-03 & 4E-02 \\
\hline
\end{tabular}

${ }^{\mathrm{a}}$ Maximum concentration detected in ground water for radionuclides was used for this calculation. The arsenic UCL exceeded the maximum detected concentration. Therefore, the maximum detected value was used.

${ }^{b}$ Calculated by multiplying the exposure dose by the slope factor.

'Uranium-234 and uranium-238 combined. The oral slope factor is the same for both isotopes.

NA - not applicable. 
in 100 of developing cancer (Table 6.2). This cancer risk level exceeds the upper-bound, acceptable risk level of 1 chance in 10,000 of developing cancer.

\section{POTENTIAL RISKS FOR THE WASATCH FORMATION}

Contaminants are present in the upper weathered Wasatch Formation along the alluvial interface (Section 3.2). Because contaminants have entered the Wasatch Formation from the overlying alluvium, potential risk from exposure to contaminants in the Wasatch is evaluated conservatively. Levels of the contaminants of concern for the weathered Wasatch Formation are lower than levels of the same contaminants in the alluvium. However, it is thought that contaminant levels in the weathered Wasatch Formation could reach levels equivalent to those in the alluvium. Therefore, potential risks identified for the contaminants of potential concern in the New Rifle alluvium are assumed to present a worst-case estimate of both noncarcinogenic and carcinogenic risks from exposure to contaminated ground water in the weathered Wasatch Formation at New Rifle.

Data are insufficient on Wasatch water quality for on-site monitor wells at the Old Rifle site. However, water quality data from off-site Wasatch monitor wells show no off-site contamination in the Wasatch Formation. This could be associated with the rapid movement of contaminants in the alluvium away from the site and likely into the Colorado River but the reason for this movement is inconclusive and further study of water quality in the Wasatch Formation beneath the Old Rifle site would be needed to verify this assumption. However, predicted contaminant concentrations in the Wasatch at Old Rifle are expected to be less than the predicted contaminant concentrations in the alluvium. Therefore, the same conservative assessment of risk is applied. Therefore, it is assumed that the potential risks identified for the contaminants of potential concern in the Old Rifle alluvium present a worst-case estimate of both noncarcinogenic and carcinogenic risks from exposure to contaminated ground water in the Wasatch Formation at Old Rifle.

\subsection{LIMITATIONS OF THE HUMAN HEALTH RISK ASSESSMENT}

The following limitations to this evaluation of health and environmental risks should be noted:

- This document evaluates risks associated with exposures to inorganic contaminants in ground water at the sites. Potential organic contaminants (related to uranium processing) are not evaluated in this baseline risk assessment.

- Uncertainties occur due to the use of filtered samples rather than unfiltered samples. In general, the results presented in this document are based on filtered (0.45-micron [ $\mu \mathrm{m}])$ water samples. The effect of filtration differs for different elements. Filtered samples for some constituents can have 
concentrations equal to those for unfiltered samples; for other constituents, filtered concentrations are lower. Constituents in suspension may be lost with filtration but still produce toxic effects if ingested and broken down in the acidic environment of the stomach.

- This risk assessment does not address all individual sensitivities to toxicity of contaminants of potential concern. Contaminant toxicities vary from person to person. Presenting probability distributions for potential exposure and exposure ranges that can produce toxic effects emphasizes these variabilities. However, it is not possible to account for all sources of variability. Specific subpopulations known to be more sensitive to the toxicities of given constituents are noted. Adverse health effects might occur at lower exposure levels in sensitive individuals.

- Standardized reference values from regulatory agencies and literature values are used to determine toxic effects in humans. However, some data obtained from laboratory animal testing at exposure doses different from those expected at the site were used to determine toxicity. The relationship between dose and response is not always linear, and humans do not always exhibit the same responses as animals. Additionally, data used to determine toxicity generally are based on exposure to only the constituent of concern. In reality, exposures generally occur simultaneously to multiple constituents. The interactive effects of multiple constituents and the impact of these interactions on expected toxicity generally cannot be assessed accurately from existing data. Toxicity, uptake, and bioconcentration data are not available for all constituents evaluated.

- Although considerable effort was directed at determining the areal extent of contaminated ground water movement and placing monitor wells in locations that capture maximum contamination, uncertainty in physical systems and models used to determine contaminant plume migration could still result in well placements that do not measure the highest contaminant concentrations or determine the fullest extent of plume impact.

- The ground water ingestion pathway is considered the major determinant of exposure in this assessment. Other expsoure pathways were screened and determined not to contribute significantly to the total exposure. However, the additivity of exposure from these pathways should be noted.

- Some variability may have been introduced through sampling and analytical processes. However, the data at UMTRA Project sites have been collected over many years and subjected to rigorous quality assurance procedures. Testing multiple samples introduces high confidence in the reliability and validity of the collected data.

By presenting ranges of toxic effects, probable exposure distributions, summaries of available data on health effects and interactions, and outlines of 
potential limitations, this risk assessment ensures a reasonable interpretation of potential health risks associated with ground water contamination at these sites. The assessment describes contamination and risk as accurately as possible, based on available data, and conveys areas of uncertainties. 


\subsection{ECOLOGICAL EVALUATION}

This section assesses the potential for site-related contaminants to adversely affect the existing biological communities, grazing livestock, and agricultural practices in the area. Currently, the EPA has no guidance for quantifying potential ecological impacts of the release of hazardous contaminants; however, the EPA has developed a qualitative approach for ecological risk evaluations (EPA, 1989a). As part of this qualitative approach, the EPA recommends conducting ecological assessments in a phased approach to ensure the most effective use of resources while all necessary work is conducted (EPA, 1992b). This approach consists of four increasingly complex phases, starting with identifying potentially exposed habitats (phase 1), collecting chemistry data (phase 2), collecting biological samples (phase 3), and conducting toxicity testing (phase 4). If the initial inspection of the habitats and the analysis of media samples indicate little or no potential for ecological risk, the assessment will likely be complete. If the early phases of the assessment indicate the contaminants may be adversely affecting ecological receptors, a higher level of analysis may be warranted.

This screening assessment evaluates the ecological environment of the two Rifle sites as one unit. Ecological risk assessment of the Rifle sites consists of the first two phases, because habitats may have been impacted (phase 1) and water chemistry data are available (phase 2). Thus, this qualitative approach provides a screening level assessment of the risks associated with potential exposure to contaminated media at the sites.

Due to the complexity of the ecosystem, it is often difficult to determine if contaminants have affected the biological component of an ecosystem and to predict whether observed effects will damage the ecosystem. However, sampling environmental media such as surface water can help assess potential ecological risk. For such an ecological risk to occur, a source of contamination must exist and this source must have a pathway to the biological communities. The following sections identify the areas of contamination and the potential pathways by which this contamination may be entering the aquatic and terrestrial biological communities at the Rifle sites, the potential ecological receptors at the sites, the contaminants of potential concern, and the hazards the contaminants of potential concern may pose to ecological resources, livestock, and agricultural crops.

\subsection{EXPOSURE CHARACTERIZATION}

The only currently impacted medium at the sites is the contaminated ground water. This assessment determines if contaminated ground water discharged from the sites could affect the ecological environment in the surface water bodies in the vicinity of the sites (i.e., Colorado River, ponds, wetlands). Under the UMTRA Surface Project, the tailings piles and associated contaminated soil were removed from the sites by the summer of 1994. Therefore, direct exposure pathways such as incidental ingestion or dermal contac: with contaminated soil and inhalation of air containing contaminated particulates are no longer possible and do not present an ecological concern. Other direct exposure pathways such as ingestion of contaminated surface water and sediment and plant uptake of contaminated ground water and indirect exposure 
pathways such as consumption of previously exposed organisms (e.g., fish) are possible at the sites.

The net accumulation by organisms of a constituent directly from the surrounding environment (e.g., water, sediment, soil) is known as bioconcentration. Net accumulation by organisms as a result of all routes of exposure, including diet, is known as bioaccumulation. Generally, bioconcentration measures chemical uptake from water by aquatic organisms. BCFs for chemicals uptake from soil by plants are too variable and dependent on site conditions; therefore, generic soil BCFs have not been established.

\subsubsection{Ground water}

A potential current exposure pathway is plant uptake of contaminants in ground water. Due to the shallow depth to ground water (approximately 5 to $10 \mathrm{ft} \mathrm{[1.5}$ to $3 \mathrm{ml}$ or less below land surface) (DOE, 1992a), some deeper-rooted plants can reach contaminated ground water. In addition, the shallow ground water is discharging to the surface in some areas and forming wetlands. For example, a wetland west of the New Rifle site in an S-shaped drainage swale runs from the western site boundary to near the gravel pit (Figure 7.1). This area is referred to as the New Rifle ditch wetlands. In addition, a 34.2-ac (13.8-ha) wetland is planned at and near the New Rifle site (Figure 7.1) to provide mitigation for wetlands eliminated during surface remediation. This wetland is referred to as the mitigation wetland. Most: plants in this planned wetland would obtain water from the shallow alluvial aquifer. This risk assessment will evaluate the potential ecological effect of constructing the mitigating wetland.

To evaluate plant uptake at the Old Rifle and New Rifle sites, plant roots were assumed to reach soil saturated with ground water containing the UCLs for the contaminants of potential concern from the most contaminated wells at each site. Screening benchmarks for potential toxicity to terrestrial plants, developed by Oak Ridge National Laboratory, were used in this evaluation (Will and Suter, 1994). A plant uptake study designed to evaluate contaminants specific to UMTRA sites is under way. When they are available, the results of this study will be evaluated in the context of the Rifle sites.

Historically, the land in the vicinity of the Rifle sites has not been used for livestock grazing. Although it is possible that in the future an alluvial domestic well could be installed in contaminated ground water to create a livestock watering source (i.e., a pond, which could also be stocked with fish) or to irrigate agricultural crops, these scenarios are considered unlikely. Based on the proximity of available surface water (e.g., an extensive ditch irrigation system and the Colorado River) it is unlikely that ground water would be used as a source of water for agricultural activities. Thus, hypothetical use of ground water for agricultural activities is not considered further in this assessment. 


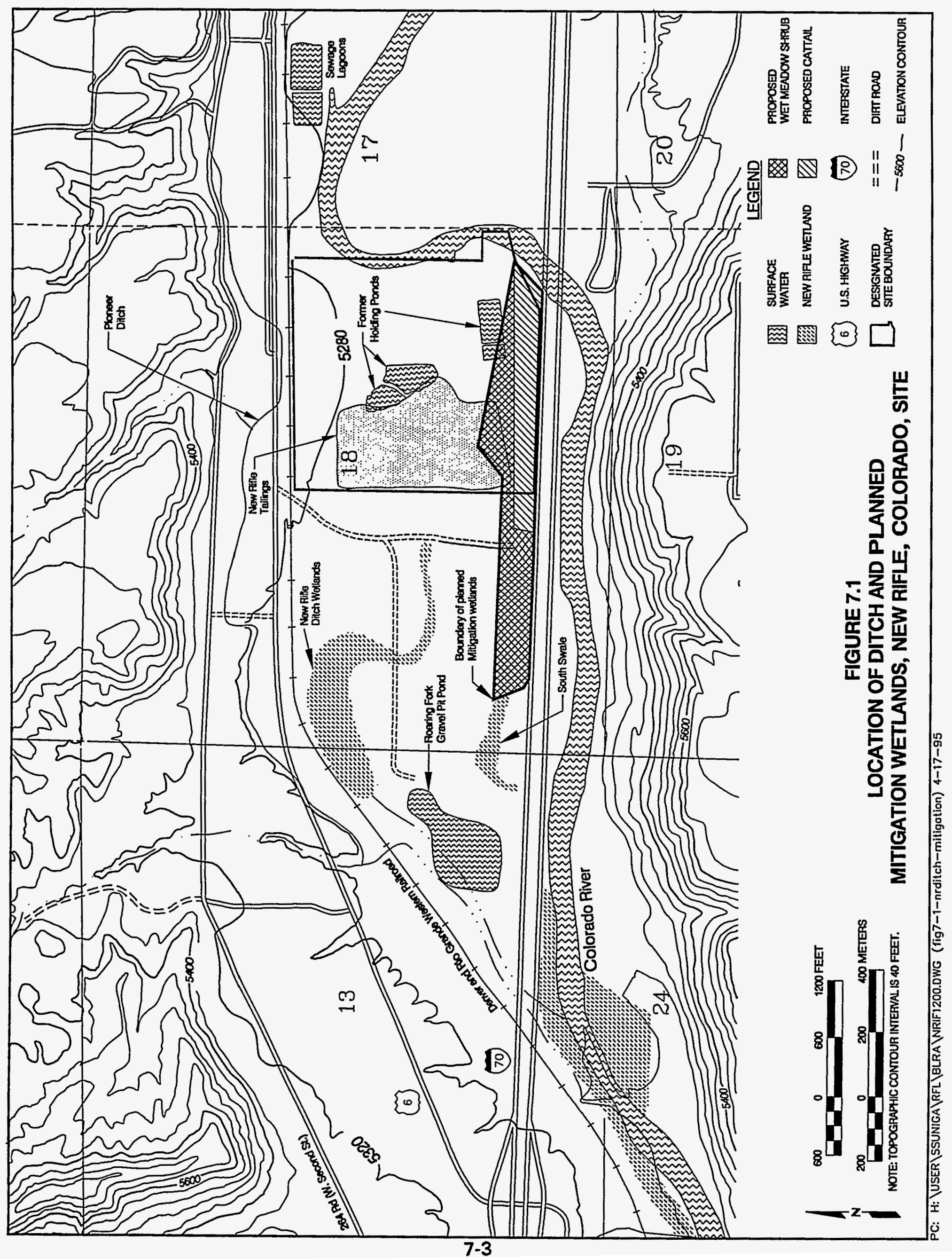




\subsubsection{Surface water and sediment}

The main surface water body in the area of the Rifle processing sites is the Colorado River. In addition to the river, several irrigation ditches provide water for agricultural uses in the Rifle area. The source of water for this irrigation ditch system is Rifle Creek, far upgradient of potential site influence. There are three ponds in the vicinity of the former processing sites: the Old Rifle pond, the New Rifle gravel pit pond, and One Mile Pond (Figure 2.12). One Mile Pond is approximately $1300 \mathrm{ft}(400 \mathrm{~m})$ upgradient (east) of the Old Rifle site, and represents a background pond. There are several seeps and springs in the vicinity of the sites. However, they all are outside the influence of the sites (i.e., upgradient) and were not evaluated in this assessrnent. The New Rifle ditch wetlands represent a surface water exposure point that could come from ground water discharge.

Surface water bodies are potential exposure points (surface water and/or sediment) for resident aquatic and terrestrial wildlife. These exposure pathways were evaluated for the ecological screening assessment.

\subsection{ECOLOGICAL RECEPTORS}

The following information on ecological receptors is based on limited field reconnaissance surveys and other sources such as the Rifle environmental impact statement (EIS) (DOE, 1990).

\subsubsection{Terrestrial flora and fauna}

\section{Old Rifle}

As with the New Rifle site, the Old Rifle site is highly disturbed due to surface remediation. The site is in the floodplain of the Colorado River and the southern boundary is separated from the river by railroad tracks; to the north a steep slope leads up to U.S. Highway 6. Riparian plant communities exist to the west with clumps of cottonwoods interspersed among willow and grass-dominated plant communities. Wetlands occurred on the site along a drainage ditch that dissected the site (DOE, 1990). These wetlands were eliminated during remedial action and will be replaced by the mitigation wetlands at the New Rifle site. More details regarding the flora and fauna at the Rifle sites appears in the Rifle EIS (DOE, 1990).

\section{New Rifle}

The land at the New Rifle processing site currently is disturbed by ongoing surface remediation. A brief field survey was conducted of the open land just west of the New Rifle site in the upper floodplain of the Colorado River (TAC, 1994). Fairly dense growths of grass and scattered shrubs cover the ground. The low lying areas contain dense mats of salt grass; no standing water was observed, although some of these areas may be fairly wet in the spring. Brome 
grass and wheatgrass dominate the grassland areas that are slightly higher than the salt grass flats. Scattered shrubs also occur in the slightly elevated areas with black greasewood and rabbitbrush the most common species. A few salt cedar and big sagebrush are also evident.

The east end of the area surveyed was at the gravel pit; the south swale (Figure 7.1) was observed near this pit. There was a dense growth of weedy plants such as Russian thistle and knapweed in this swale; no wetland species were observed. This swale was bordered by a fairly dense growth of salt cedar. Two cottontail rabbits and mule deer tracks were observed here.

A fairly large wetland complex was observed in the New Rifle ditch north and east of the gravel pit (Figure 7.1); plant community types in this complex varied with elevation. The lowest lying areas contained standing water with cattail and sedge plant communities. The water depth was generally 6 inches $(15 \mathrm{~cm})$ or less, although a few areas had water as deep as 18 inches $(46 \mathrm{~cm})$. Three active muskrat dens were observed; one was about $2.5 \mathrm{ft}(0.76 \mathrm{~m})$ tall. Muskrat cuttings and trails through the wetland indicated muskrat live in this wetland. Sedge and rushes were dominant in the saturated soil next to the open water with salt grass becoming dominant in the higher areas. Salt cedar occurred in thin bands around the periphery of this wetland. A shallow pond is just north of gravel pit access road. This pond was about $50 \mathrm{ft}(15 \mathrm{~m})$ across and little wetland vegetation growth was noted, which may indicate the pond is ephemeral. The wetland continued in a channel on the south side of the gravel pit access road and curved toward the New Rifle site (Figure 7.1). There was no standing water and the ground was covered with a dense growth of salt grass. An extensive growth of spikerush was noted in the middle of this channel. This wetland complex may be in an old meander channel of the Colorado River and the water in the wetland likely is derived from ground water.

Surface remediation at the Rifle sites resulted in the elimination of 11 ac (5 ha) of wetlands. The mitigation plan for the loss of these wetlands is in the Rifle Section 404 Permit; the plan consists of creating a 34.2-ac (14 ha) wetland at the south end of the New Rifle site (Figure 7.1). The mitigation wetland would consist of three plant community types: $12.3 \mathrm{ac}(5 \mathrm{ha})$ of emergent plants such as cattail and bulrush; 16.4 ac ( 7 ha) of wet meadow planted with various grass species; and 5.5 ac (2.2 ha) of shrub wetlands planted with willow and a grass ground cover (Figure 7.1) (USACE, 1992). The east end of the wetlands would be near the Colorado River; the western section would be up to $700 \mathrm{ft}(200 \mathrm{~m})$ north of the river. The wetlands would be created by excavating 3 to $4 \mathrm{ft}(1 \mathrm{~m})$ down to the water table; the wet meadow and shrub wetlands would generally be just above the water table, while the cattail wetland would be 0.5 to $1 \mathrm{ft}$ $(0.2$ to $0.3 \mathrm{~m})$ below this elevation during the spring and summer of an average precipitation year.

From an ecological risk perspective, wildlife species that inhabit the New Rifle ditch wetlands and those that would inhabit the mitigation wetlands are of interest because the water source for both these wetlands is the contaminated 
alluvial aquifer. Detailed wildlife surveys were not conducted at the sites; wildlife that likely would occur were determined from the pertinent literature. Amphibians and reptiles that may occur include the Woodhouse toad, northern leopard frog, racer, corn snake, bullsnake, and western terrestrial garter snake (Hammerson, 1986).

Marsh birds are apparently the wildlife group most sensitive to selenium, a contaminant of potential concern at the mitigation wetlands. Therefore, an extensive list of birds that may nest at this site was complied. Fifty-one species of breeding birds may occur at or near the mitigation wetlands (Table 7.1). Breeding bird studies in marsh habitat show that density is quite high and can range from $\mathbf{2 5 0}$ to $\mathbf{4 0 0}$ or more breeding pairs per hundred acres (Van Velzen, 1980). Based on these numbers, the projected breeding bird density at the 34-ac (14-ha) mitigation wetlands would be 85 to 136 pairs.

The mitigation wetlands probably would attract aquatic mammals such as muskrat. This species lives in the New Rifle Ditch wetlands. However, the mitigation wetlands are not expected to provide year-round habitat for the muskrat because standing water will be present only during the spring and summer. Small mammals such as voles and mice and larger mammals such as rabbit, hares, raccoons, and mule deer would be expected to use these wetlands.

\subsubsection{Aquatic organisms}

In the area of the Rifle sites, the Colorado River meanders through agricultural and residential areas and around gravel and vegetated islands. The river has large annual fluctuations in flow, temperature, and turbidity. No quantitative surveys of aquatic organisms in the surface water bodies in the vicinity of the sites have been conducted as part of a Technical Assistance Contractor investigation. A brief qualitative survey of the aquatic organisms in the New Rifle ditch wetland was conducted in December 1994. The following organisms were observed using a fine-mesh dip net: water striders, backswimmers, and mosquito and midge larvae. No fish were observed.

Fish known to occur in the Ciolorado River in the Rifle area are the bluehead sucker, flannelmouth sucker, common carp, roundtail chub, and fathead minnow. Game species include the green sunfish, black bullhead, brown trout, and rainbow trout. Fishing has been observed at the Old Rifle pond, but the fish species that occur in this pond, or potentially occur in the New Rifle gravel pit, is not known.

\subsubsection{Threatened and endangered species}

The U.S. Fish and Wildlife Service (FWS) has not been consulted about the status of threatened and enclangered (T\&E) species at the Rifle sites since the site-specific EIS was published. The following discussion is based on 
Table 7.1 Bird species that could nest at the mitigation wetlands, Rifle, Colorado, sites

\begin{tabular}{|c|c|c|c|}
\hline & Habitat & Breoding season & Diet \\
\hline Pied-Billed Grebe & M, L & April - May & Fish, aquatic invertebrates \\
\hline Great Blue Heron & $R, S, L$ & March - May & Fish, aquatic invertebrates, small vertebrates \\
\hline $\begin{array}{l}\text { Black-Crowned Night } \\
\text { Heron }\end{array}$ & $M, L, S$ & April - July & Fish, aquatic invertebrates \\
\hline Canada Goose & $M, L, S$ & March - June & Aquatic vegetation, grass, invertebrates \\
\hline Mallard & $M, L, S$ & March - July & Aquatic vegetation, aquatic invertebrates, grain \\
\hline Gadwall & $M, L, S$ & April - July & Aquatic vegetation, aquatic invertebrates \\
\hline Pintail & $M, L, S$ & May - July & Aquatic vegetation \\
\hline Green-Winged Teal & $M, L, S$ & May - August & Aquatic invertebrates, seeds, aquatic vegetation \\
\hline Blue-Winged Teal & $M, L, S$ & May - July & Aquatic vegetation \\
\hline Cinnamon Teal & $M, L, S$ & May - June & Aquatic vegetation \\
\hline American Widgeon & $M, L, S$ & May - June & Aquatic invertebrates, aquatic vegetation \\
\hline Common Merganser & $M, L, S, R$ & May - June & Fish, aquatic invertebrates \\
\hline Northern Harrier & $M$ & March - July & Small vertebrates, insects \\
\hline American Kestrel & $M, L, S$ & April - June & Small vertebrates, insects \\
\hline Virginia Rail & $M$ & May - July & Aquatic invertebrates, seeds \\
\hline Sora & $\mathbf{M}$ & April - July & Insects, aquatic invertebrates \\
\hline American Coot & $M, L$ & April - July & $\begin{array}{l}\text { Aquatic vegetation, aquatic invertebrates, } \\
\text { insects }\end{array}$ \\
\hline Killdeer & $M, L, S$ & April - July & Insects \\
\hline Common Snipe & $\mathbf{R}$ & April - July & Insects, small invertebrates \\
\hline Spotted Sandpiper & $L, S$ & May - July & Aquatic invertebrates \\
\hline Common Nighthawk & $\mathbf{R}$ & April - July & Insects \\
\hline Belted Kingfisher & $\mathbf{R}$ & April - July & Fish, small invertebrates \\
\hline Western Kingbird & $\mathbf{R}$ & April - July & Insects, berries \\
\hline Say's Phoebe & $\mathbf{R}$ & March - July & Insects, berries \\
\hline Willow Flycatcher & $\mathbf{R}$ & May - July & Insects, berries \\
\hline Olive-Sided Flycatcher & $\mathbf{R}$ & May - July & Insects \\
\hline Barn Swallow & $R, M, L, S$ & April - July & Insects \\
\hline Cliff Swallow & $R, M, L, S$ & April - August & Insects \\
\hline Black-Billed Magpie & $\mathbf{R}$ & March - June & Omnivorous \\
\hline Common Crow & $\mathbf{R}$ & February - June & Omnivorous \\
\hline Dipper & $\mathbf{s}$ & March - June & Aquatic invertebrates, fish \\
\hline
\end{tabular}


Table 7.1 Bird species that could nest at the mitigation wetlands, Rifle, Colorado, sites (Concluded)

\begin{tabular}{llll}
\hline & Habitat & Breading season & \\
\hline Bewick's Wren & R & March - June & Insects \\
Northern Mockingbird & R & March - August & Insects, fruit \\
Gray Catbird & R & May - August & Insects, fruit \\
American Robin & R & April - July & Insects, fruit \\
European Starling & R & April - July & Insects, fruits, seeds \\
Yellow Warbler & R & April - July & Insects \\
Common Yellowthroat & M & April - July & Insects \\
Yellow-Breasted Chat & M, R & April - August & Insects, berries \\
Green-Tailed Towhee & R & May - April & Insects, seeds, berries \\
Rufous-Sided Towhee & R & April- August & Insects, seeds, fruit \\
Savannah Sparrow & M & March - July & Insects, seeds, snails \\
Chipping Sparrow & R & March - August & Insects, seeds \\
Song Sparrow & M & February - August & Insects, seeds \\
Yellow-Headed Blackbird & M & April - June & Insects, fruits \\
Red-Winged Blackbird & M & March - July & Insects, seeds \\
Northern Oriole & R & May - June & Insects, fruit, nectar \\
Brewer's Blackbird & R & March - July & Insects, seeds, fruits \\
Black-Headed Grosbeak & R & April - July & Insect, seeds, fruits \\
American Goldfinch & R & June - September & Seeds, insects \\
Lesser Goldfinch & R & April - August & Seeds, insects \\
\hline M-marsh & & &
\end{tabular}

$M-$ marsh.

$\mathbf{R}$ - riparian.

S - stream/river.

$L$ - lake/pond. 
information in this document, although the status of T\&E species at and near the Rifle sites may have changed since publication.

The bald eagle and the razorback sucker are the only federally listed T\&E species that occurs regularly near the Rifle sites. The bald eagle winters along the Colorado River and is occasionally seen in the vicinity. This species also nests along the river about $2 \mathrm{mi}(3 \mathrm{~km})$ upriver from the Old Rifle site. The razorback sucker occurs in the river in the area of both sites. More details regarding T\&E species at the sites can be found in the Rifle EIS (DOE, 1990).

7.3 ECOLOGICAL CONTAMINANTS OF POTENTIAL CONCERN

\subsubsection{Ground water}

The complete list of ground water constituents that exceed background ground water for the Old Rifle and New Rifle sites (Tables 3.1 and 3.2) was used as the list of contaminants of potential concern for ecological receptors potentially exposed to ground water (e.g., plant uptake). This list includes 15 inorganics for the Old Rifle site and 20 inorganics for New Rifle.

\subsubsection{Surface water and sediment}

To determine the contaminants of potential concern for surface water and sediment, the list of ground water contaminants of potential concern was first compared with the surface water and sediment data. Tables 3.3 and 7.2 present the surface water and sediment data, respectively, for those contaminants detected in the respective media and above background levels in ground water. Constituents not detected in a particular medium (for example arsenic, cadmium, nitrate, molybdenum, selenium, vanadium, and zinc in Colorado River water, and molybdenum and selenium in Colorado River sediments) were excluded as contaminants of potential concern in that medium. Additionally, constituents detected at concentrations less than or equal to the background concentrations were not evaluated further.

Filtered and unfiltered analyses were performed for several rounds of surface water sampling events from 1986 to 1994 . The sampling locations were not analyzed for the same parameters during all sampling events, nor were all the locations sampled during each sampling event. Given the variability in past surface water sampling rounds, the most recent surface water data (collected in March 1994) were used for this ecological risk assessment. These 1994 data also more accurately represent current conditions at the Rifle sites.

Surface water samples have not been collected from the New Rifle ditch wetlands since 1992 (location RFN-01-0576); that sampling showed elevated levels of severai constituents. These wetlands were sampled again in December 1994. When these data become available, they will be evaluated with respect to background water quality, other locations, and historical data. 
The surface water data are based on unfiltered samples. These data are compared with the state of Colorado's water quality standards, which are based on filtered concentrations. The use of unfiltered data likely will result in a conservative evaluation because the concentrations of filtered metals usually are less than the unfiltered concentrations.

Surficial sediment samples ( 0 to 4 inches [0 to $10 \mathrm{~cm}$ ] deep) were collected from 12 locations in March 1994. Sediments were analyzed for nine of the constituents that exceeded background in ground water (arsenic, cadmium, iron, manganese, molybdenum, selenium, uranium, vanadium, and zinc). Sediment was sampled once before, at location RF0-01-0572.

The surface water bodies are divided into three separate areas for this assessment:

- Colorado River, with locations RFO-01-0538 (background) and RFN-01-0545 and -0548.

- Ponds, with locations RFO-01-0570 (background, One Mile Pond) and -0572 (Old Rifle pond), and RFN-01-0575 (Roaring Fork gravel pit pond).

- Swale/ditch, with locations RFN-01-0538 (the swale southeast of the gravel pit pond) and -0540 (drainage ditch).

\section{Colorado River - water}

Several constituents were not detected in water at any sampling location in the river, and thus were excluded as contaminants of potential concern: arsenic, cadmium, molybdenum, nitrate, selenium, vanadium, and zinc. Additionally, calcium, chloride, fluoride, magnesium, manganese, potassium, silica, sodium, sulfate, and uranium are excluded as contaminants of potential concern because the concentrations detected at the downstream locations are less than or similar to background concentrations.

After these comparisons, ammonium and iron were selected as contaminants of potential concern for the Colorado River water.

\section{Colorado River - sediment}

Molybdenum and selenium were eliminated as contaminants of potential concern for the river sediments, because they were not detected at any location. Additionally, iron, uranium, and zinc were excluded from evaluation because they were detected at concentrations less than or similar to background concentrations. 
After these comparisons were made, the following contaminants of potential concern were selected for the Colorado River sediment: arsenic, cadmium, manganese, and vanadium.

\section{Ponds - water}

The following constituents were not detected in water collected from any of the ponds: arsenic, selenium, vanadium, and zinc. The following constituents were excluded because the concentrations detected in the Old Rifle pond and/or the New Rifle gravel pit pond were less than or similar to concentrations detected in background (One Mile Pond): cadmium, iron, manganese, and silica. Although cadmium was detected in the Old Rifle pond, it was eliminated from the assessment because it was cletected at the detection limit $(0.001 \mathrm{mg} / \mathrm{L})$ and this concentration is well below the aquatic life water quality standard and available wildlife toxicity benchmark concentrations.

After these comparisons were made, the following contaminants of potential concern were selected for pond water: ammonium, calcium, chloride, fluoride, magnesium, molybdenum, nitrate, potassium, sodium, sulfate, and uranium.

\section{Ponds - sediment}

No sediment samples have been collected from the New Rifle gravel pit pond. Molybdenum was not detected in the Old Rifle pond sediments and iron was excluded from consideration because it was detected at a concentration similar to the background concentration.

Thus, the contaminants of potential concern for ecological receptors exposed to sediments in the Old Rifle pond are identified as arsenic, cadmium, manganese, selenium, uranium, vanadium, and zinc.

\section{Swale/ditch - water}

Contaminants of potential concern cannot be identified because no standing water was found at locations RFN-01-0538 and RFN-01-0540 during the March 1994 sampling.

Water samples were collected in February 1991 and October 1992 from the New Rifle ditch wetland (Figure 7.1). The concentrations for several constituents detected in the water samples collected during the dry season (October 1992) were the highest ever detected in relation to area surface water bodies. The constituents include chloride, fluoride, iron, manganese, molybdenum, potassium, sodium, sulfate, uranium, vanadium, and zinc. Seasonal conditions (i.e., evaporation and concentration) may have caused the elevated values detected in the water samples collected in October. Therefore, the 1991 and 1992 data from location RFN-01-0576 were not used in this preliminary ecological risk assessment. Because the New Rifle ditch wetland is apparently fed by alluvial ground water, water quality clata from a nearby alluvial 
aquifer monitor well (RFN-01-0598) were used to determine contaminants of potential concern; 16 constituents are above background and represent contaminants of potential concern.

\section{Swale/ditch - sediment}

No background swale or ditch areas have been sampled as part of the site characterization activities. Thus, the background river and pond locations were used in selecting the contaminants of potential concern. The following constituents were excluded as contaminants of potential concern because they were detected at concentrations less than or similar to background concentrations: cadmium, iron, selenium, vanadium, and zinc.

After the comparisons to background, arsenic, manganese, molybdenum, and uranium were identified as contaminants of potential concern for ecological receptors.

Contaminants of potential concern in the sediment at the New Rifle ditch wetland were not determined because sediment samples have not been collected.

\section{Mitigation wetlands - surface water}

Water for the mitigation wetland would come from the contaminated alluvial aquifer associated with the New Rifle site. This wetland would be constructed by excavating to or just below the estimated elevation of the alluvial aquifer water table during June of an average precipitation year. To determine the quality of water that would feed the mitigation wetland, water quality data from the contaminated New Rifle alluvial aquifer were analyzed. These data indicated that 20 constituents were above background alluvial ground water levels (Table 7.3) and that these constituents represent contaminants of potential concern for the planned mitigation wetlands.

\section{Mitigation wetlands - sediments}

Data regarding the concentrations of constituents of potential concern for the sediments of the mitigation wetlands do not exist.

\section{$7.4 \quad$ POTENTIAL IMPACTS TO WILDLIFE AND PLANTS}

The exposure pathways that could potentially impact wildlife and plants are discussed below. 
Table 7.3 Constituents of potential concern in the alluvial aquifer at the mitigation wetland and the New Rifle ditch wetland (well RFN-01-0598)

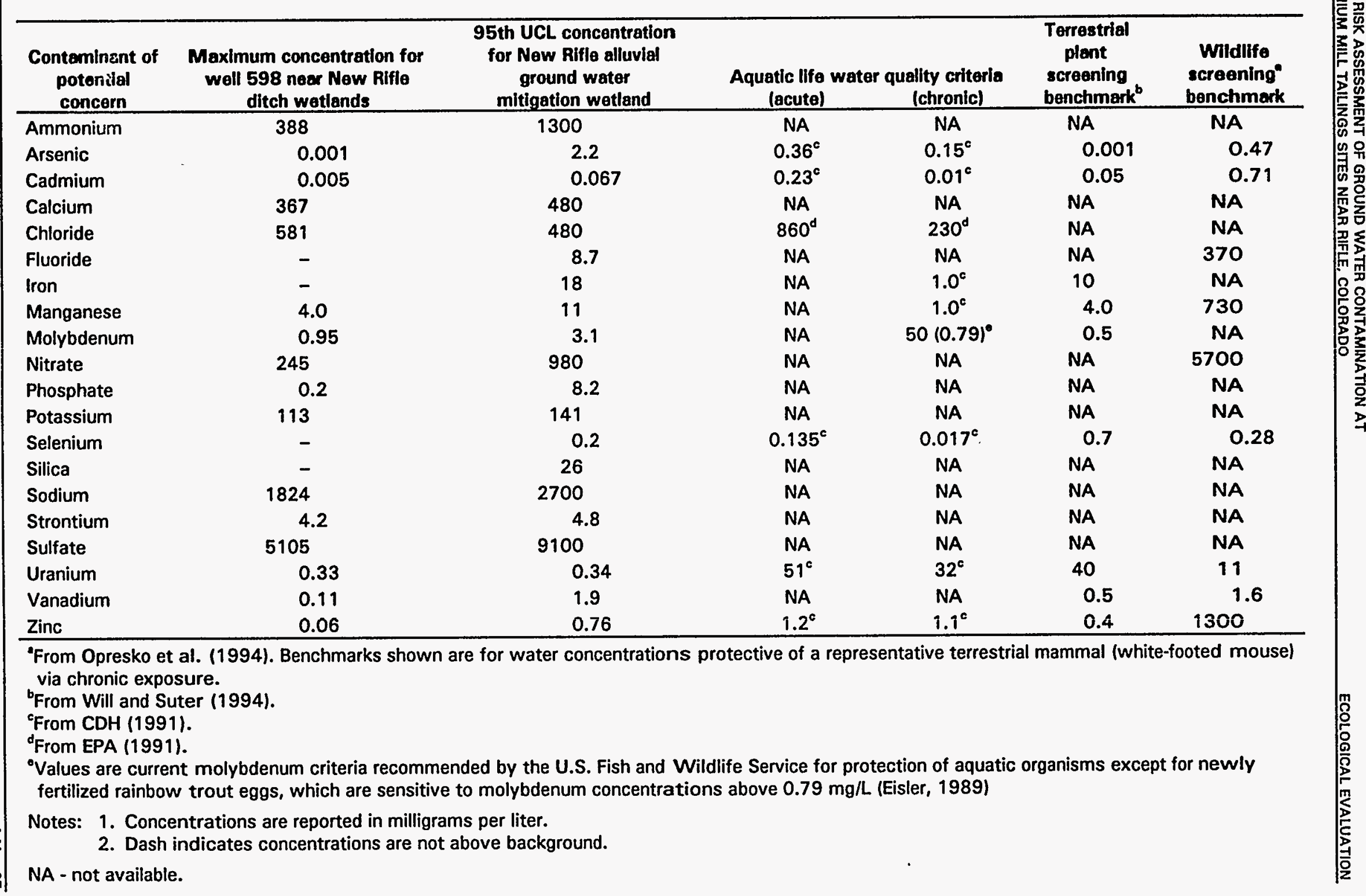




\subsubsection{Ground water}

\section{Terrestrial vegetation}

Terrestrial vegetation can be directly exposed to contaminants in ground water through uptake by the roots. Contaminants may bioaccumulate in various plant parts and exert a wide range of influences, depending on the specific contaminant. Plant uptake rates and toxicity vary greatly among species and are affected by factors such as soil characteristics $(\mathrm{pH}$, moisture, redox potential, organic matter), plant sensitivity, input-output balance, and cumulative effects. Foraging wildlife can be indirectly exposed to contaminants in ground water by ingesting plants that have bioaccumulated certain contaminants.

To evaluate whether contaminated ground water could adversely affect vegetation through root uptake, phytotoxicity screening benchmarks derived by Oak Ridge National Laboratory were compared to the contaminants of potential concern (Will and Suter, 1994). The benchmarks are based on the results of tests conducted in nutrient solutions and are assumed to be representative of root exposure to constituents in the contaminated alluvial aquifer at the Rifle sites. There are no state or federal toxicity benchmark values for terrestrial plants.

\section{Old Rifle}

No seeps, springs, or wetlands were observed at the Old Rifle site. However, because of the shallow depth to ground water, plant roots could access contaminated ground water. A comparison of the UCL concentrations for the ground water contaminants to the screening benchmarks indicate the concentration of vanadium $10.72 \mathrm{mg} / \mathrm{L})$ slightly exceeds the benchmark $10.5 \mathrm{mg} / \mathrm{L})$. Although there are no screening benchmarks for 8 of the 15 contaminants of potential concern, the potential for ground water conditions at the Old Rifle site to threaten vegetation is considered low based on available information.

\section{New Rifle}

The potential for plants to accumulate contaminants of potential concern from the alluvial aquifer at the New Rifle site is greatest in wetlands that are fed by the alluvium. There are no recent data available regarding the water quality in the New Rifle ditch wetland. This wetland looked healthy during a brief field survey in November 1994 (TAC, 1994). An analysis of the constituents in the alluvial ground water near this wetland, based on data from monitor well RFN01-0598 indicates manganese and molybdenum concentrations slightly exceed (or are equal to) the terrestrial vegetation benchmarks (Table 7.3).

The mitigation wetland will contain surface water from May into September during an average precipitation year. Presumably, the plants growing in this wetland will receive most of their water from the contaminated alluvial ground 
water associated with the New Rifle site. A comparison of 95 percent $U C L$ concentrations with the terrestrial plant benchmark indicates that arsenic, cadmium, iron, manganese, molybdenum, vanadium, and zinc are all above the benchmarks (Table 7.3).

\section{Terrestrial and aquatic fauna}

The direct consumption of contaminated water and the bioaccumulation of contaminants of potential concern in terrestrial and aquatic fauna (from ingesting lower food chain organisms) are potential exposure pathways at the site. Animals consuming contaminated plants and animals can bioaccumulate some of the contaminants of potential concern if the amount ingested exceeds the amount eliminated. Bioaccumulation often is a function of the areal extent of contamination versus the areal extent of the animal's feeding range. In small contaminated areas such as a seep, the feeding range of many animal species will exceed the size of the contaminated area and bioaccumulation may not be a concern. In larger areas such as the mitigation wetlands, the home range of many more species can be contained within the wetland and bioaccumulation could be of concern. The potential for bioaccumulation of the contaminants of potential concern in the mitigation and New Rifle ditch wetlands is discussed below. Additional information would be required to make a conclusive determination regarding bioaccumulation and food-chain transfer of the contaminants of potential concern at these two wetlands.

The principal potential pathways contaminated ground water could follow to enter the food chain at the Rifle sites are the New Rifle ditch wetlands and the mitigation wetlands (Figure 7.1). (This discussion assumes the mitigation wetlands will be constructed although the final decision has not been made). The source of water for both wetlands is the alluvial aquifer. Table 7.3 lists the 20 contaminants of potential concern. The potential effects of the contaminants of potential concern on the biota at these two wetlands are discussed below.

\section{Constituents with aquatic life water quality criteria}

State or federal aquatic life criteria were available for comparison for nine constituents (Table 7.3); the following constituents were below the criteria and will not be considered further in this assessment.

- New Rifle ditch wetlands: arsenic, cadmium, iron, selenium, uranium, and zinc.

- Mitigation wetlands: uranium and zinc.

At the planned mitigation wetlands, arsenic would exceed the state acute and chronic criteria. However, the maximum arsenic concentration from alluvial monitor wells in this area is $0.08 \mathrm{mg} / \mathrm{L}$, which is below the criteria. Therefore, 
adverse effects are not expected from the arsenic levels in the planned mitigation wetlands.

Molybdenum concentrations at both wetland areas were well below levels that could result in chronic adverse effects to most of the biota that would inhabit both wetlands. A value of $0.79 \mathrm{mg} / \mathrm{L}$ can cause chronic effects to fertilized trout eggs. However, the mitigation wetland would not support a fish population because the wetland is ephemeral. It is not known if the New Rifle ditch wetlands contains fish; presumably, because the mean concentration of molybdenum in well 598 is just above $0.79 \mathrm{mg} / \mathrm{L}$, molybdenum probably is not a problem for fish that may inhabit this wetland. Therefore, it is believed that molybdenum does not threaten biota at the wetlands and it is not considered further.

The constituents addressed below exceed state and/or federal criteria in one or both of the wetlands and may pose an ecological risk.

\section{Cådmium}

Cadmium exceeds the state acute and chronic criteria at the mitigation wetlands (Table 7.3). It has been estimated that cadmium concentrations greater then $0.003 \mathrm{mg} / \mathrm{L}$ in freshwater will likely result in pronounced effects on aquatic organisms and wildlife (Eisler, 1985). One reason cadmium is toxic at such low levels is its tendency to bioaccumulate; BCFs of 33 to 7440 have been calculated for freshwater insects and algae (Eisler, 1985). Therefore, cadmium levels could adversely affect organisms that may inhabit the planned mitigation wetlands.

\section{Chloride}

Chloride concentrations exceed the chronic Federal Water Quality Criterion (FWOC) $(230 \mathrm{mg} / \mathrm{L})$ considered protective of aquatic life at both sites (Table 7.3). Data regarding the nature and severity of the effects of elevated chloride on aquatic and terrestrial ecological systems are not available.

\section{Iron}

Iron concentrations are elevated above the state chronic criterion considered protective of aquatic life at the mitigation wetlands (Table 7.3). Iron is expected to reach the mitigation wetlands when the ground water rises and floods part of the wetlands in the spring or early summer; it would precipitate out and accumulate on the bottom of the wetlands. This iron may also stimulate the growth of iron bacteria, which may form a slime on the bottom or on vegetation (SWPCB, 1952). These iron deposits and/or bacteria may inhibit the development of invertebrate populations in the wetland, thereby decreasing its usefulness to wildlife. 


\section{Manganese}

Manganese concentrations in the contaminated alluvial aquifer at both wetlands exceed the state water quality criterion for chronic exposure of aquatic life $(1 \mathrm{mg} / \mathrm{L})$. Water quality conditions that would likely occur at both wetlands, which include neutral $\mathrm{pH}$ and high salinity, are conducive to a manganese oxidation state of $\mathrm{Mn}^{2+}$, which is a soluble and bioavailable form of manganese (Sims, 1986; Khattak and Jarrell, 1989). This indicates that when water enters the wetlands, manganese would remain in solution and be bioavailable. Further, when the wetlands dry out, manganese would form a crust on the surface that would become resuspended when water returns to the area.

Another avenue for manganese to reach the mitigation wetlands is from plants rooted in the contaminated alluvial aquifer. Since manganese would be taken up by plants in contaminated ground or surface water, the manganese probably would return to the water and sediment when the plants decay. Manganese is expected to circulate through the wetlands annually. In addition, as manganese enters the wetlands each spring with the rising water table, concentrations likely will increase over time. Cycling manganese through the wetland probably will have deleterious effects on the aquatic organisms and wildlife, especially at the mitigation wetlands where the concentrations would be greater.

\section{Selenium}

The selenium UCL in the contaminated New Rifle alluvial ground water is $0.2 \mathrm{mg} / \mathrm{L}$, which exceeds the state acute and chronic criteria. Selenium could enter the mitigation wetlands directly from the alluvial aquifer and from plants rooted in the aquifer. Selenium that enters a relative closed system could cycle through this environment for vears, even after the source of selenium in the ground water is gone. The mitigation wetlands would be a relatively closed system in that there would be little inflow and outflow of water; such a system could take several decades to recover from selenium contamination (Lemly and Smith, 1987).

Selenium bioconcentrates as it moves up the food chain and may result in reproductive abnormalities or failure, and even death in marsh birds. For example, irrigation drainage water entering Kesterson National Wildlife Refuge in California contained an averaģe concentration of $0.122 \mathrm{mg} / \mathrm{L}$ selenium (DuBowy, 1989). Selenium concentrated in the vegetation $(69$ to $154 \mathrm{mg} / \mathrm{kg}$ depending on the species) and aquatic invertebrates $(100 \mathrm{mg} / \mathrm{kg}$ ) while the only surviving fish species (mosquitofish) contained an average of $170 \mathrm{mg} / \mathrm{kg}$ selenium in its tissue (Ohlendorf, 1989). These concentrations in the food resulted in the near-complete reproductive failures and mortality of marsh birds such as the cor.t. grebe, stilt sandpiper, and avocet. Mammals contained elevated concentrations of selenium, but these levels had apparently not resulted in reproductive or other types of impacts to mammals at the Kesterson refuge (Clark, 1987; Clark et al., 1989). 
Selenium concentrations in the mitigation wetlands would be similar to concentrations at Kesterson National Wildlife Refuge. Several varieties of marsh bird species may nest at the mitigation wetlands, and the selenium levels could adversely affect their reproduction and survival (Table 7.1). In addition, birds that use this site may accumulate selenium in their tissues that would be harmful if the birds were consumed by humans. For example, multiplying the BCF of 1430 for mallards (DuBowy, 1989) by $0.2 \mathrm{mg} / \mathrm{L}$ selenium in the water results in $286 \mathrm{ppm}$ selenium in mallard breast meat, which is above the maximum recommended $1 \mathrm{ppm}$ for edible portions of waterfowl (DuBowy, 1989).

\section{Constituents without aquatic life water quality criteria}

Toxicity data are available for some constituents that exceed background concentrations but do not have state or federal aquatic life water quality criteria.

\section{Ammonium}

The toxic component of ammonium is un-ionized ammonia (EPA, 1973), and the amount of un-ionized ammonia varies with $\mathrm{pH}$ and water temperature. Very little un-ionized ammonia is present below a pH of 7.0. The average $\mathrm{pH}$ of the alluvial ground water beneath both sites is about 7.0; at a water temperature of 16 degrees celsius $\left({ }^{\circ} \mathrm{C}\right)$, the percent of un-ionized ammonia would be 0.30 . An ammonium concentration of $1300 \mathrm{mg} / \mathrm{L}$ would be $3.9 \mathrm{mg} / \mathrm{L}$ ammonia. This concentration could be toxic to fish, which have a benchmark of $1.7 \mathrm{mg} / \mathrm{L}$, but is well below levels that may be toxic to aquatic invertebrates (daphnids) $(630 \mathrm{mg} / \mathrm{L})$ or aquatic plants (2400 mg/L) (Boyd, 1979). Therefore, because the mitigation wetlands would not support a fish population, ammonia concentrations in the alluvial ground water likely would not threaten the mitigation wetlands. Ammonium concentrations in well 598 near the New Rifle ditch wetlands are less than at the mitigation wetlands and do not pose an ecological risk.

\section{Sodium}

Sodium concentrations are elevated in the contaminated alluvial aquifer at the mitigation wetlands. The sodium absorption ratio is 19 . Water with such a high sodium absorption ratio could cause soil to become hard and impermeable if the water were applied to an upland area. The impact of high sodium concentrations on the mitigation wetlands is not known. However, analysis of the ground water quality data from the alluvial aquifer near the New Rifle ditch wetlands showed a sodium absorption ratio of 17 . This ratio indicates the high sodium levels that likely will occur in the mitigation wetland may not have an adverse effect. 


\section{Vanadium}

Studies indicate that acute vanadium toxicity of freshwater aquatic organisms ranges from 6.4 to $30.8 \mathrm{mg} / \mathrm{L}$ (Smith et al., 1991). The vanadium concentration in the contaminated alluvial aquifer $(1.9 \mathrm{mg} / \mathrm{L})$ is below these toxic levels; therefore, it is assumed that vanadium would not result in toxic effects to aquatic organisms in the mitigation wetlands.

An additional potential exposure pathway for terrestrial wildlife at the New Rifle ditch and mitigation wetland could be the use of contaminated water for drinking. Federal and state criteria and standards have not been established for the protection of terrestrial wildlife via water exposure. However, toxicity benchmarks are available for several mammals (Opresko et al., 1994). Similar to the terrestrial plant benchmarks discussed previously, the wildlife benchmarks were developed to screen out potential contaminants. The wildlife screening benchmarks were derived from NOAELs obtained from contaminant-specific toxicity tests on laboratory animals. Opresko et al. (1994) describe the derivation of the wildlife screening benchmarks.

For this screening-level assessment, a terrestrial mammal, the white-footed mouse, was selected as the indicator species to evaluate the potential adverse effects associated with exposure to contaminated water in the wetlands. Although screening benchmarks exist for larger mammals (e.g., coyote, whitetail deer, cottontail rabbit) or could be derived (e.g., birds), the white-footed mouse was selected for the following reasons: it is known to occur in the local area (DOE, 1990); it has a relatively small home range; and it has a relatively short life span. Thus, the wetlands could represent an important source of water and food for the white-footed mouse and similar rodent species. While other animals (e.g., rabbits, deer) and birds (e.g., waterfowl) could access the wetland area, they probably would not spend as much time at this wetland area (and therefore have less exposure) as mice. Also, other ecological receptors could have different or lesser sensitivity to the contaminants of potential concern.

A comparison of the wildlife screening benchmarks to monitor well 598 water quality data indicate none of the contaminants of potential concern exceed the terrestrial wildlife benchmarks at the New Rifle ditch wetlands (Table 7.3).

Ground water arsenic and vanadium concentrations in the mitigation wetland, exceed the wildlife benchmarks, indicating this water could represent a hazard via chronic exposure to white-footed mice and to other species that have similar or greater sensitivity to arsenic and vanadium. No screening benchmarks are available for ammonium, calcium, chloride, iron, molybdenum, phosphate, potassium, silicia, sodium, strontium, or sulfate (Table, 7.3). 


\subsubsection{Surface water and sediment}

\section{Colorado River water}

Aquatic life in the Colorado River may be exposed to contaminants associated with the site. The zones of contaminated ground water are believed to discharge to the river. It is also possible that contaminants have discharged into the river through surface water runoff before surface remediation removed the contaminated material from the Rifle sites.

The Colorado River surface water contaminants of potential concern lammonium and iron) were compared to available water quality standards for aquatic life. Iron concentrations adjacent $(0.84 \mathrm{mg} / \mathrm{L})$ and downstream $(0.52 \mathrm{mg} / \mathrm{L})$ of the sites did not exceed the state water quality standard of $1 \mathrm{mg} / \mathrm{L}$. No water quality standards or criteria are available for evaluating the effects of ammonium on aquatic life. Therefore, surface water quality data suggest contaminated ground water discharging from the sites is greatly diluted as it enters the Colorado River.

Terrestrial wildlife that access the river could be exposed to contaminants in water (e.g., plants via root uptake and aquatic organisms via drinking). A comparison of the detected surface water concentrations of iron to the screening benchmarks for terrestrial plants indicates the concentrations do not exceed the iron benchmarks. No benchmarks are available with which to evaluate the potential adverse effects of iron on terrestrial wildlife or ammonium on terrestrial plants and wildlife.

\section{Pond water}

To evaluate the potential for adverse effects to aquatic and terrestrial organisms exposed to surface water in the ponds in the vicinity of the sites (Old Rifle pond and New Rifle gravel pit pond), the contaminants of potential concern were compared to the water quality standards for the protection of aquatic life and to the screening benchmarks for terrestrial plants and animals (represented by the white-footed mouse) (Table 7.4).

In general, concentrations detected in the Old Rifle pond were similar to the background water concentrations in One Mile Pond; none of the concentrations exceeded aquatic standards or terrestrial benchmarks (Table 7.4). Most constituent levels in the New Rifle gravel pit pond are elevated relative to background. However, a conclusive determination of the cause for the higher concentrations detected in the gravel pit cannot be made. While the gravel pit is directly downgradient of the New Rifle site and could be receiving contaminated ground water, it is also possible that the normal activities associated with operation of the gravel pit (e.g., turbation of the water, digging, etc.) could be acting to increase the levels of the contaminants of potential concern in the water. 
Table 7.4 Comparison of contaminants; of potential concern in surface water from ponds in the vicinity of the sites with available water quality values, Rifle, Colorado, sites

\begin{tabular}{lcccccc}
\hline $\begin{array}{c}\text { Contaminant of } \\
\text { potential } \\
\text { concern }\end{array}$ & $\begin{array}{c}\text { Old Rifle } \\
\text { Pond } \\
\text { (RFO-01- } \\
\text { 0572) }\end{array}$ & $\begin{array}{c}\text { New Rifle } \\
\text { gravel pit } \\
\text { pond } \\
\text { (RFN-01- } \\
\text { 0575) }\end{array}$ & $\begin{array}{c}\text { One Mile Pond } \\
\text { (background) } \\
\text { (RFO-01-0570) }\end{array}$ & $\begin{array}{c}\text { Aquatic life } \\
\text { water } \\
\text { quality } \\
\text { value }\end{array}$ & $\begin{array}{c}\text { Terrestrial } \\
\text { plant } \\
\text { screening } \\
\text { benchmark }\end{array}$ & $\begin{array}{c}\text { Wildlife } \\
\text { screening } \\
\text { benchmark }\end{array}$ \\
\hline Ammonium & 0.45 & 120 & $<0.1$ & NA & NA & NA \\
Calcium & 52 & 305 & 86 & NA & NA & NA \\
Chloride & 52 & 220 & 40 & $230^{\text {d }}$ & NA & NA \\
Fluaride & 0.24 & 0.48 & 0.29 & NA & NA & 370 \\
Magnesium & 14 & 120 & 65 & NA & NA & NA \\
Molybdenum & $<0.01$ & 0.18 & $<0.01$ & $50(0.79)^{\circ}$ & 0.5 & NA \\
Nitrate & $<1.0$ & 200 & $<1.0$ & NA & NA & 5700 \\
Potassium & 2.4 & 77 & 8.9 & NA & NA & NA \\
Sodium & 39 & 1200 & 64 & NA & NA & NA \\
Sulfate & 59 & 3200 & 250 & NA & NA & NA \\
Uranium & 0.017 & 0.31 & 0.010 & $30^{f} ; 25^{\circ}$ & 40 & 11 \\
\hline
\end{tabular}

From CDH (1991), unless specified otherwise. Standards are protective of aquatic life via chronic exposure.

From Will and Suter (1994).

'From Opresko et al. (1994). Benchmarks shown are for water concentrations protective of a representative terrestrial mammal (white-footed mouse) via chronic exposure.

${ }^{d}$ No state water quality value available. Value presented is the Federal Water Quality Criterion for the protection of freshwater aquatic life via chronic exposure (EPA, 1992d).

Values are current molybdenum criteria recommended by the U.S. Fish and Wildife Service for the protection of aquatic organisms except for newly fertilized trout eggs, which are sensitive to molybdenum concentrations above $0.79 \mathrm{mg} / \mathrm{L}$ (Eisler, 1989).

'Water hardness-related state standard (CDH, 1991). Criterion presented was calculated using the mean hardness (190 mg/L) determined from calcium and magnesium concentrations in the plume wells (unfiltered datal.

Water hardness-related.state standard (CDH, 1991). Criterion presented was calculated using the mean hardness $(1270 \mathrm{mg} / \mathrm{L})$ determined from calcium and magnesium concentrations in the plume wells (unfiltered data).

Note: All concentrations reported in milligrams per liter.

NA - not available. 
A comparison of the gravel pit surface water concentrations to the state water quality standards indicates that the concentrations of chloride, molybdenum, and uranium do not exceed the state standards. There are no state or federal water quality standards or criteria for the other eight contaminants of potential concern. Thus, it is not possible to evaluate the potential impact these contaminants may have on resident aquatic life.

For terrestrial plants, screening benchmarks are available for only two of the 11 contaminants of potential concern (molybdenum and uranium). Neither molybdenum nor uranium concentrations exceeded the benchmark in the gravel pit pond (Table 7.4), suggesting concentrations found in this pond would not cause adverse effects to plants. However, because screening benchmarks are not available for most contaminants of potential concern, definitive conclusions cannot be reached about the potential risk to plants.

Surface water concentrations for fluoride, nitrate, and uranium do not exceed the screening benchmarks for terrestrial wildlife (Table 7.4), which indicates the concentrations of these constituents in water would not result in adverse effects to animals with sensitivities similar to the white-footed mouse. However, some animals could be adversely affected when exposed to certain contaminants at concentrations lower than the benchmarks presented here. For example, it is well known that ruminants (e.g., cattle) are susceptible to the deleterious effects (methemoglobinemia) of nitrate concentrations as low as $100 \mathrm{mg} / \mathrm{L}$ (EPA, 1973). Thus, the concentration of nitrate in the New Rifle gravel pit pond $(200 \mathrm{mg} / \mathrm{L})$ would not be suitable for watering livestock.

\section{Colorado River sediment}

There are no established state or federal sediment quality criteria (SQC) for the protection of aquatic life for the contaminants at this site (EPA, 1988). The EPA is evaluating a methodology based on the three-phase sorption model for free-metal ion activity and is assessing its applicability for determining the bioavailable fraction within sediments (EPA, 1988). Currently, several predictive models and methods are being investigated for metals, but no single approach has been accepted to adequately develop sediment-based metals criteria (Shea, 1988; Chapman, 1989; EPA, 1988; NOAA, 1990; Di Toro et al., 1991; Burton, 1991). Therefore, only a qualitative hazard assessment of the metals detected in sediments will be presented in this risk assessment.

National Oceanic and Atmospheric Administration (NOAA) effects-based sediment quality values are available for evaluating the potential of contaminants in sediment to adversely affect aquatic organisms. The contaminants of potential concern for the river sediment are arsenic, cadmium, manganese, and vanadium. The NOAA value for arsenic is $33 \mathrm{mg} / \mathrm{kg}$ and for cadmium is $5 \mathrm{mg} / \mathrm{kg}$. However, the detected concentrations of these two metals fall below their respective NOAA values and therefore are not likely to cause adverse biological effects. Because NOAA values are not available for manganese and vanadium, their potential threat to aquatic life is difficult to 
evaluate. However, the concentrations for manganese and vanadium were compared to concentrations for naturally occurring concentrations found in surficial soil samples in the western United States (USGS, 1984). The manganese and vanadium concentrations fall within reported U.S. Geological Survey ranges.

\section{Pond sediment}

Seven contaminants of potential concern (arsenic, cadrnium, manganese, selenium, uranium, vanadium, and zinc) are elevated above background in the Old Rifle pond. Sediment samples have not been collected from the New Rifle gravel pit pond. NOAA sediment quality values are available for arsenic (33 mg/kg), cadmium (5 mg/kg), and zinc (120 mg/kg).

The cadmium $(6.4 \mathrm{mg} / \mathrm{kg})$ and zinc $(860 \mathrm{mg} / \mathrm{kg})$ concentrations detected in the Old Rifle pond sediments were above their respective NOAA sediment values, while the arsenic concentration $(9.3 \mathrm{mg} / \mathrm{kg}$ ) was below the NOAA value, indicating the potential for sediments in Old Rifle pond to impact benthic organisms. However, additional information would be required to make a definitive conclusion.

Risk to aquatic life - swale/ditch sediment

The sediment sample collected from the swale approximately $1 \mathrm{mi}(2 \mathrm{~km})$ southeast of the New Rifle site (location RFN-01-0538) contained elevated concentrations of three of the four contaminants of potential concern (manganese, molybdenum, and uranium) (Figure 7.1). The detected arsenic concentration $(3.2 \mathrm{mg} / \mathrm{kg})$ is less than background $(3.6 \mathrm{mg} / \mathrm{kg})$.

NOAA sediment values are not available for manganese, molybdenum, and uranium, and no quantitative biological evaluations of this swale have been conducted. The sediment concentrations of manganese and molybdenum detected in the swale are approximately 1 order of magnitude higher than background. However, it is not known whether these levels would adversely affect aquatic life in this drainage swale. Because the drainage swale and drainage ditch are intermittent, it is unlikely they contain a diverse or sustainable assemblage of aquatic life.

The concentrations of arsenic, manganese, molybdenum, and uranium detected in sediment from the drainage ditch (location RFN-01-0540) were very similar to concentrations detected in background sediments. Thus, it is unlikely this drainage ditch would represent a hazard to aquatic life.

\section{Fish tissue}

A single fish was collected from the Old Rifle pond in 1991 and a whole-body sample was analyzed for arsenic, cadmium, chromium, molybdenum, selenium, 
uranium, and radium-226. The results were evaluated during the previous risk assessment (DOE, 1992b).

Chromium, selenium, and uranium were detected in fish. The chromium and selenium levels detected were within the range of levels reported in fish from natural background areas (DOE, 1992b). The uranium concentration was $1.75 \mathrm{mg} / \mathrm{kg}$ dry weight, which is above the range of uranium concentrations detected in whole-body fish samples collected from a background area in a uranium mining district in Washington state $(0.09$ to $0.79 \mathrm{mg} / \mathrm{kg}$ dry weight) (Nichols and Scholz, 1989). However, a comprehensive review of the literature on uranium concentrations in fish has not been conducted and no site-specific or local area data exist on background uranium concentrations in fish. Thus, it is not possible to draw a definitive conclusion regarding the potential effects of contaminated surface water or sediment on fish in Old Rifle pond.

\section{$7.5 \quad$ LIMITATIONS OF THE ECOLOGICAL RISK ASSESSMENT}

The qualitative evaluation of potential ecological risks presented here is a screening level assessment of the risks associated with potential exposure of plants and animals to contaminated ground water, surface water, and sediment at the Rifle sites. Sources of uncertainty in any ecological assessment arise from the monitoring data, exposure assessments, toxicological information, and the inherent complexities of the ecosystem. In addition, methods of predicting nonchemical stresses (for example, drought), biotic interactions, behavior patterns, biological variability (differences in physical conditions, nutrient availability), and resiliency and recovery capacities are often unavailable. In general, the following limitations apply to the Rifle ecological risk assessment:

- Only a small amount of ecological data were collected for this screening.

- Screening benchmarks from the literature were used in this assessment.

- Only limited ecotoxicological reference data are available.

- Considerable uncertainty is associated with the toxicity of mixing contaminants.

\subsection{SUMMARY}

Surface water data from the Colorado River near the sites indicate ammonium and iron exceed background concentrations, but do not exceed available state standards for the protection of aquatic life in surface water or screening benchmarks for terrestrial wildlife and plants. Surface water data from the Old Rifle pond are similar to the background data, and the concentrations do not exceed any water quality standards or screening benchmarks for wildlife. These data suggest that although ground water is discharging into the river and the Old Rifle pond, the quality of the surface water is not discernibly affected. 
However, a definitive conclusion cannot be made at this time because of the limited data available.

Surface water quality in the New Rifle gravel pit pond has been affected, as evidenced by the elevated concentrations of several contaminants of potential concern. However, the extent to which surface water quality has been affected by the contaminated ground water from the New Rifle sites is not known, because the operating activities associated with the gravel facility likely influence conditions in the gravel pit water. None of the contaminants of potential concern were detected in the water at concentrations exceeding state water quality standards for the protection of aquatic life or terrestrial plant and wildlife screening benchmark values. Although livestock do not have access to the New Rifle gravel pit pond currently, nor are they expected to in the future, based on projected future land use, the nitrate concentrations in the gravel pit would prohibit using it as a water source for livestock.

In general, sediment concentrations for the contaminants of potential concern detected at the Colorado river locations and the drainage ditch location (RFN 540) were similar to background concentrations. This similarity suggests activities at the sites have not measurably affected the sediment quality in these water bodies. The concentrations of two contaminants of potential concern detected in sediment from the Old Rifle pond exceeded their respective NOAA sediment quality values. Thus, these concentrations could affect aquatic organisms. However, because this conclusion is based on limited data, a definitive conclusion cannot be made at this time.

At the Old Rifle site, plants are the only ecological receptors that could be directly exposed to contaminated ground water. Due to the shallow depth to ground water, some types of plants could be exposed to contaminants via root uptake. Based on the available data and screening benchmarks, it is unlikely that plants exposed via root uptake to contaminated ground water at the Old Rifle site would be adversely affected.

Construction of the mitigation wetlands at the New Rifle site, which would receive contaminated alluvial ground water, could represent a hazard to ecological receptors. Five of the contaminants of potential concern in this ground water exceed their respective federal or state water quality standards for the protection of aquatic life via short-term and/or chronic exposure. Ground water concentrations exceed one contaminant-specific screening benchmark for terrestrial wildlife and seven benchmarks for terrestrial plants.

Tissue from biota (for example, plants) has not been analyzed. However, bioaccumulation of selenium, cadmium, and manganese is considered possible in the planned mitigation wetlands. The effect of the Colorado River on the planned mitigation wetlands was not considered when the potential adverse ecological effects were evaluated. The dilution and dispersion effects of the river could decrease contamiriant concentrations at the planned mitigation wetlands. However, wetlands in the Rifle area are strongly affected by 
evaporation, and as ground water would enter the wetlands and evaporate during drier times of the year, contaminants could build up over time in surface water and sediments. Therefore, postconstruction monitoring of surface water, sediments, and biota is recommended if the mitigation wetland is built in the planned location.

The water quality of monitor well RFN-01-0598 may be indicative of surface water quality at the New Rifle ditch wetlands. Water quality analysis in well 598 indicates two contaminants of potential concern exceed the water quality criteria considered protective of aquatic life, one screening benchmark for terrestrial wildlife, and two screening benchmarks for terrestrial plants. 


\subsection{INTERPRETATIONS AND RECOMMENDATIONS}

This baseline risk assessment conducted for the two former uranium mill sites, Old and New Rifle, evaluates the human health hazards associated with inorganics and radionuclides present in the ground water beneath the sites. It also presents the results of a screening assessment of the ecological environment.

At the Old Rifle site, the alluvial contaminant plume has not migrated far from the site. The main discharge zone for the alluvial aquifer at Old Rifle is the Colorado River. Ground water quality in the Wasatch Formation at Old Rifle has not been characterized; therefore, the vertical movement of contamination has not been characterized. However, due to the low hydraulic conductivity of the Wasatch Formation at Old Rifle, a large downward vertical migration is not expected.

At New Rifle, the vertical extent of the contaminant plume has been partially defined. Contaminants present in the alluvial ground water beneath the New Rifle site have migrated downward into the upper weathered zone of the Wasatch Formation. The same contaminants are present in the Wasatch Formation and the alluvium, but concentrations are higher in the alluvium and the contaminants appear to migrate along the interface between the alluvium and in the upper weathered zone of the Wasatch horizontally rather than penetrating vertically into the lower Wasatch Formation. Because ground water in the alluvium is hydraulically connected to ground water in the upper weathered Wasatch Formation, the risk evaluation using the concentrations detected in the alluvium is assumed to represent a worst case evaluation of contamination in the Wasatch Formation at New Rifle.

Ground water in the alluvium and weathered Wasatch Formation, in the area of the Rifle sites, is considered poor tasting and unpotable because of naturally occurring high sulfate and TDS levels. Consequently, private well users (residential, commercial, and agricultural) in the area do not use ground water for drinking water. Private well users that are not connected to the Rifle municipal water supply system drink bottled water. Ground water from private wells is used for other purposes, however, such as bathing, livestock watering, and garden irrigation. The hydrogeology and geochemical evaluation of the ground water in this report indicates that, with one possible exception, none of the existing private wells are affected by the former uranium mill processing activities nor are they expected to be in the future. Therefore, neither current nor future private wells users have been identified as receptors of contaminated ground water.

The possible exception is private well RFN-01-0428 downgradient of New Rifle, although the source of the constituents (e.g., plume indicators nitrate, sulfate, and uranium) in this well has not been determined. As discussed in Section 4.4.1, after the New Rifle plume is characterized (as part of the site observational work plan), well RFN-01-0428 will be reevaluated to determine if the constituents detected in this well are from the former New Rifle processing site. The potential for exposure will also be revaluated at that time. 


\subsection{HUMAN HEALTH RISK SUMMARY}

\section{Current health risks}

No one is currently drinking the contaminated ground water at or adjacent to either the Old or New Rifle site. Additionally, the exposure concentrations that people could receive from the other current exposure pathways (surface water and sediment ingestion and dermal contact, and fish ingestion) would not be expected to cause adverse hiealth effects if they were the only source of exposure. Therefore, there is no current risk of adverse health effects due to ground water consumption at: these sites. This situation will continue if water use near the sites does not change.

\section{Future health risks}

Future development of properties at and downgradient from the former processing sites is possible. Although municipal drinking water is available in the vicinity of the former processing sites, it cannot be assumed that a well will never be constructed in the contaminated portion of the aquifer. Therefore, future risks from using contaminated ground water as a drinking water source were evaluated for both sites. This is a conservative evaluation of future ground water use because 1) due to the poor water quality in the Rifle area and the availability of the municipal water supply, future use of the ground water is unlikely; 2) the source of contamination (the tailings) is being removed; and 3) dilution and dispersion effects in the contaminated aquifers are expected to decrease contaminant concentrations, thereby decreasing exposure concentrations over time.

Adverse health effects could occur if contaminated ground water were directly ingested as drinking water at both the Old and New Rifle sites.

\section{Old Rifle}

The noncarcinogenic contaminants of potential concern that could cause adverse health effects at Old Rifle are sulfate, manganese, iron, molybdenum, and fluoride. These contaminants could cause the following adverse health effects. Sulfate exposure could cause laxative effects in adults and severe diarrhea leading to dehydration in infants. Manganese exposure could cause neurological symptoms. Iron exposure could cause the bioaccumulation of iron in body organs and cause skin pigmentation. Molybdenum toxicity could manifest as a copper deficiency, which could impair the oxygen-carrying capacity of the blood and lead to anemia. Fluoride exposure could cause dental mottling.

At Old Rifle, lead-210, polonium-210, radium-226, thorium-230, and uranium were evaluated as carcinogens. All radionuclides are considered Class A carcinogens (known human carcinogens). The total individual excess lifetime cancer risk of 2E-03 ( 2 chances in 1000 of developing cancer) exceeded the 
upper bound, acceptable risk level of 1 E-04 (1 chance in 10,000 of developing cancer). Of the four radionuclides, uranium was the major contributor of potential carcinogenic risk. Additionally, the total excess lifetime cancer risk for arsenic (a Class A carcinogen) was 5E-03 (5 chances in 1000 of developing cancer). This risk level also exceeded the upper bound, acceptable risk level of 1E-04 (1 chance in 10,000 of developing cancer).

\section{New Rifle}

The noncarcinogenic contaminants of potential concern that could cause mildto-severe adverse health effects at New Rifle are arsenic, manganese, nitrate, selenium, sodium, chloride, molybdenum, fluoride, iron, and vanadium. These contaminants could cause the following adverse health effects. Arsenic could cause adverse neurological effects, with increasing intakes leading to more severe toxicity such as cirrhosis of the liver. Manganese exposure could cause neurological symptoms and at higher exposures, Parkinson-like effects. Infants could develop mild-to-severe methemoglobinemia from nitrate exposure. Mild toxicity manifested as nail and hair brittleness/loss could occur from selenium exposure. Sodium and chloride would increase the chance for developing hypertension. Molybdenum toxicity would manifest as a copper deficiency that could impair the oxygen-carrying capacity of the blood, leading to anemia. Sulfate could cause laxative effects in adults and severe diarrhea leading to dehydration in infants. Fluoride exposure could cause dental mottling. Iron exposure could cause bioaccumulation of iron in body organs and skin pigmentation leading to cirrhosis of the liver. Vanadium exposure could cause sudden drops in cholesterol levels.

Lead-210, polonium-210, radium-226, thorium-230, and uranium were evaluated as carcinogens. The total individual excess lifetime cancer risk 4E-04 (4 chances in 10,000 of developing cancer) exceeded the upper bound, acceptable risk level of 1E-04 (1 chance in 10,000 of developing cancer). Of the four radionuclides, uranium and lead-210 are the major contributors of potential carcinogenic risk.

Additionally, the total individual excess lifetime cancer risk for arsenic was 4E-02 (4 chances in a 100 of developing cancer). This cancer risk level also exceeded the upper bound, acceptable risk level of 1E-04 (1 chance in 10,000 of developing cancer).

\subsection{ECOLOGICAL RISK SUMMARY}

Surface water data from the Colorado River near the sites indicate ammonium and iron exceed background concentrations, although there are not enough data to determine the cause of this difference. The concentrations do not exceed available state standards for the protection of aquatic life in surface water or screening benchmarks for terrestrial wildlife and plants. Surface water data from the Old Rifle pond are similar to the background data, and the detected concentrations of constituents do not exceed any water quality standards or 
screening benchmarks for wildlife. These data suggest that although ground water is discharging into the river and the Old Rifle pond, the quality of the surface water is not discernibly affected. However, a clefinitive conclusion cannot be made at this time because data are limited.

Surface water quality in the Foaring Fork gravel pit pond has been affected as evidenced by the elevated concentrations of several contaminants of potential concern. However, if or how contaminated ground water from the New Rifle site has affected water quality is not known, because operating activities associated with the gravel facility may have influenced conditions in the gravel pit water. None of the contaminants of potential concern were detected in the water at concentrations higher than state water quality standards for the protection of aquatic life, or terrestrial plant and wildlife screening benchmark values. Although livestock currently cannot access the Roaring Fork gravel pit pond and are not expected to in the future, existing nitrate concentrations prohibit use of the gravel pit as a water source for livestock.

The sediment concentrations for the contaminants of potential concern detected at the Colorado River locations and the drainage ditch location were generally similar to background concentrations. This similarity suggests activities at the sites have not discernibly affected the sediment quality in these water bodies. The concentrations of two contaminants of potential concern detected in sediment from the Old Rifle pond exceeded their respective NOAA sediment quality values. Thus, these concentrations could affect aquatic organisms. However, because this conclusion is based on limited data, a definitive conclusion cannot be made at this time.

Due to the shallow depth to ground water at the Old Rifle site, plants are the only ecological receptors that could be directly exposed (via root uptake) to contaminated ground water. Available data and screening benchmarks indicate it is unlikely that plants exposed via root uptake at this site would be adversely affected.

Construction of the mitigation wetlands at the New Rifle site, which would receive contaminated alluvial ground water, could threaten ecological receptors. Five of the contaminants of potential concern in this ground water exceed their respective short-term exposure state water quality standards for the protection of aquatic life. In addition, ground water concentrations exceed three of the contaminant-specific screening benchmarks for terrestrial wildlife, and seven benchmarks for terrestrial plants.

Tissue from biota (e.g., plants) has not been analyzed. However, bioaccumulation of selenium, cadmium, and manganese is considered possible in the mitigation wetlands.

Water quality analysis of moritor well RFN-01-0598 indicates two contaminants of potential concern exceed the water quality criteria considered protective of 
aquatic life. Contaminants in well 598 also exceed one screening benchmark for terrestrial wildlife and two for terrestrial plants.

\subsection{GROUND WATER STANDARDS}

In 1983, the EPA established health and environmental protection standards for the UMTRA Project (40 CFR Part 192). The standards were revised and the final rule was published 11 January 1995 (60 FR 2854). The ground water standards consist of protection standards for evaluating disposal cell performance and cleanup standards for cleaning up existing contamination at processing sites. While these ground water standards apply specifically to the UMTRA Project, the EPA has also published health-based drinking water health advisory levels for both long- and short-term exposures (Table 8.1). Table 8.1 summarizes MCLs for constituents at the Rifle sites, although MCLs are not established for every constituent detected at the Rifle sites.

The constituents that have exceeded MCLs in the plume wells evaluated in this risk assessment are arsenic, cadmium, lead, molybdenum, nitrate, selenium, and uranium. All these constituents are contaminants of potential concern.

Antimony, arsenic, cadmium, lead, molybdenum, nitrate, thallium, vanadium, and uranium exceeded the health advisory for these constituents. Of these, only thallium is not a contaminant of potential concern. Thallium was detected infrequently (in 1 of 5 analyses at the New Rifle site only, and this value was at the detection limit).

\section{$8.4 \quad$ RISK MITIGATION MEASURES}

Institutional controls are defined in the EPA ground water standards as mechanisms that can be effectively used to protect human health and the environment by controlling access to contaminated ground water. Although the EPA standards refer to long-term institutional controls (e.g., up to 100 years during natural flushing), they also be can applied to short-term restriction of access to contaminated ground water. Because all 24 UMTRA Project sites cannot be evaluated simultaneously, short-term institutional controls may be needed before remedial action decisions can be made and implemented for the individual sites.

\section{Well permits}

All the Colorado UMTRA Project sites are on the Colorado Western Slope and are outside the designated ground water basins. Well construction outside the designated basins requires a written application to the state engineer for a permit to const uct a new well. Designated basins are isolated hydrogeologic areas where groundwater use is stringently evaluated, based on the demands for water rights. The state engineer is required to act on applications for new well permits within $\mathbf{4 5}$ days after their receipt. If a well could affect existing 
Table 8.1 Maximum concentration limits of constituents

\begin{tabular}{|c|c|c|c|c|}
\hline Constituent & $\begin{array}{c}\text { UMTRCA MCL } \\
(\mathrm{mg} / \mathrm{L})\end{array}$ & $\begin{array}{l}\text { Health advisory } \\
\text { 10-kg child, 10-day } \\
\text { (mg/L) }\end{array}$ & $\begin{array}{l}\text { Health advisory } \\
\text { 10-kg child, } \\
\text { longer-term } \\
\text { (mg/L) }\end{array}$ & $\begin{array}{l}\text { Health advisory } \\
\text { 70-kg adult lifetime } \\
\text { (mg/L) }\end{array}$ \\
\hline \multicolumn{5}{|c|}{ Chemicals (inorganic) } \\
\hline Ammonium & - & - & & - \\
\hline Antimony & - & $0.015^{\circ}$ & $0.015^{\circ}$ & $0.003^{a}$ \\
\hline Arsenic & $0.05^{\circ}$ & - & - & $0.002^{a, b}$ \\
\hline Barium & 1.0 & - & - & 2 \\
\hline $\begin{array}{l}\text { Boron } \\
\text { Cadmium }\end{array}$ & $\dot{0.01}$ & $\begin{array}{l}0.9 \\
0.04^{a}\end{array}$ & $\begin{array}{l}0.9 \\
0.005^{\circ}\end{array}$ & $\begin{array}{l}0.6 \\
0.005^{\circ}\end{array}$ \\
\hline Chloride & - & - & - &. \\
\hline Chromium & 0.05 & 1.0 & 0.2 & 0.1 \\
\hline Cobalt & - & - & - & - \\
\hline Copper & - & - & - & - \\
\hline Fluoride & - & - & - & - \\
\hline Iron & - & - & - & - \\
\hline Lead & $0.05^{\circ}$ & - & - & $0.015^{\circ}$ \\
\hline Manganese & - & - & - & - \\
\hline Mercury & 0.002 & - & - & 0.002 \\
\hline Molybdenum & $0.1^{\circ}$ & $0.08^{8}$ & $0.01^{\circ}$ & $0.04^{\circ}$ \\
\hline Nickel & - & 1 & 0.5 & 0.1 \\
\hline Nitrate(as $\mathrm{NO}_{3}$ ) & $44^{8, c}$ & $44^{\circ}$ & - & - \\
\hline Selenium & $0.01^{\circ}$ & - & - & - \\
\hline Silver & 0.05 & 0.2 & 0.2 & 0.1 \\
\hline Sodium & - & - & - & - \\
\hline Strontium & - & 25 & 25 & 17 \\
\hline Sulfate & - & - & - & - \\
\hline Thallium & - & $0.007^{\mathrm{a}}$ & $0.007^{a}$ & $0.0004^{\circ}$ \\
\hline Vanadium & - & $0.08^{\mathrm{a}}$ & - & $0.02^{\circ}$ \\
\hline Zinc & - & 6 & 3 & 2 \\
\hline Radionuclides & & & & \\
\hline Lead-210 & - & - & - & - \\
\hline Polonium-210 & - & - & - & - \\
\hline Radium-226/-228 & $5 \mathrm{pCi} / \mathrm{L}$ & - & - & $20 \mathrm{pCi} / \mathrm{L}^{\mathrm{b}}$ \\
\hline Thorium-230 & - & - & - & - \\
\hline $\begin{array}{l}\text { Uranium } \\
\text { (U-234/-238) }\end{array}$ & $\begin{array}{c}30 \mathrm{pCi} / \mathrm{L}^{\circ} \\
(0.044 \mathrm{mg} / \mathrm{L})^{\circ}\end{array}$ & - & - & $0.70 \mathrm{pCi} / \mathrm{L}^{a, b}$ \\
\hline
\end{tabular}

${ }^{a}$ Exceeded in one or more plume wells.

bThese health advisory values correspond to a 10-04 cancer risk. The health advisory for radium-226/radium-228 is $20 \mathrm{pCi} / \mathrm{L}$ each (not combined).

${ }^{c} 30 \mathrm{pCi} / \mathrm{L}$ is equal to $0.044 \mathrm{mg} / \mathrm{L}$ if secular equilibrium is assumed between uranium-234 and uranium-238.

Dash indicates that standards or advisories are not available. 
water rights or if an applicant attempts to establish a legal right, adjudication likely would be required before a permit is granted.

\section{Ground water quality}

The Colorado Department of Public Health and Environment (CDPHE) is the state agency responsible for setting water quality standards. Within the CDPHE, the State Water Quality Commission is responsible for adopting water quality standards and classifications for state waters in Colorado.

The state of Colorado ground water quality standards require ground water to be free of substances in concentrations shown to be "carcinogenic, mutagenic, teratogenic or toxic to human beings and/or a danger to public health, safety or welfare" (CDH, 1990).

The state engineer is authorized to enforce the state water quality standards but does not have jurisdiction to deny a drilling permit for a new well based on water quality, because the state does not regulate private well water quality. The state engineer's office can issue a warning to well users if a well is placed in an aquifer known to be contaminated. Well water that will be consumed by 25 or more people must meet state water quality standards and use can be restricted by the CDPHE, Water Quality Control Division, Drinking Water Section.

\section{Land restrictions}

The former processing sites are outside the Rifle city limits and are not subject to city requirements. Garfield County currently has jurisdiction over the former processing sites.

There are no mechanisms to restrict drilling and use of ground water on private property in the city or county. Within the city limits, water used domestically has traditionally been provided by the city water system. If the city annexed the sites, all new construction would first require approval from the City Planning Department and then require connection to the city water and sewer system. However, these requirements do not preclude drilling and using ground water on private property. New construction on land within Garfield County must be approved by the county commissioners unless the property is contiguous with the city (as the Rifle sites are), in which case the City Planning Department could approve the new development (Levenworth, 1994).

\subsection{RECOMMENDATIONS}

Currently, human health is not at risk from the use of the contaminated ground water associated with the Rifle sites. However, adverse health effects could occur in the future if the ground water were used as drinking water. Therefore, control of future ground water use is recommended for both the alluvial and Wasatch Formation aquifers. 
To fully characterize the risks associated with the Old and New Rifle sites, the following recommendations are presented:

- The off-site horizontal extent of the New Rifle contaminant plume (west of the New Rifle site) and the vertical extent of the Old Rifle contaminant plume should be characterized during future site characterization and remedial action activities.

- Organic constituents in ground water should be studied more extensively during future site characterization activities.

- The plant ingestion pathway has not been evaluated for human health; therefore, when research information is available, this pathway should be evaluated.

- Based on the limited fish tissue analyses, a definitive conclusion cannot be made regarding the fish ingestion pathway for humans or the ecological effects to the fish; therefore, additional fish tissue analyses are recommended to characterize these pathways.

- The screening level ecological assessment is based on limited surface water and sediment data; therefore, additional data for these two media should be collected so the ecological environment at the Rifle sites can be better characterized. Also, the additional data could be used to verify the results of the human health screening evaluation of these media.

- If the mitigation wetland is constructed at the planned location, a postconstruction monitoring program should be implemented to determine if the contaminants enter the wetlands as predicted and if they pose a potential ecological risk. 


\subsection{LIST OF CONTRIBUTORS}

The following individuals were primarily responsible for the preparation of this report.

\begin{tabular}{|c|c|}
\hline Name & Contribution \\
\hline $\begin{array}{l}\text { M. Day, B. Malczewska-Toth, } \\
\text { J. Marshall }\end{array}$ & Risk assessment; toxicology \\
\hline C. Burt, C. Day, M. Randall & Pathway analysis; ecology \\
\hline K. Smith & Statistics \\
\hline T. Monks & Hydrogeology \\
\hline D. Erskine & Geochemistry \\
\hline M. Gawthrop Cooper & Document coordination; risk mitigation measures \\
\hline J. Gibb, J. Storm, L. Ulland & Senior technical review \\
\hline A. Holm, T. Jackson, R. Saar & Technical review \\
\hline S. Wright & Site manager \\
\hline J. Torline & Technical editing, document production coordination \\
\hline L. Sanchez & Text processing \\
\hline E. Bond, B. Harvey, S. Suniga & Graphic design \\
\hline
\end{tabular}




\subsection{REFERENCES}

Aiyar, A. S., and A. Sreenivasan, 1961. Proc. Soc. Exp. Biol. Med., Vol. 107, pp. 914-916.

Alexander et al. (F. W. Alexander, B. E. Clayton, and H. T. Delves), 1974. Quarterly Journal of Medicine, Vol. 53, pp. 89-111.

AQUIRE (Aquatic Information Retrieval), 1992. Computerized database developed by the U.S. Environmental Protection Agency.

ATSDR (Agency for Toxic Substances and Disease Registry), 1990. Toxicological Profile for Ammonia, Agency for Toxic Substances and Disease Registry.

Ballou et al. (J. E. Ballou, R. A. Gies, A. C. Case, D. L. Haggard, R. L. Buschbom, and J. L. Ryan), 1986. "Deposition and Early Disposition of Inhaled Uranium-233 Uranyl Nitrate and Uranium-232 Uranyl Nitrate in the Rat," in Health Physics, No. 51, pp. 755-772.

Belehova, B. A., 1969. Scientific Transactions of the Irkutsk State Medical Institute, in Russian, Vol. 96, pp. 20-23.

Bolyai et al. (J. Z. Bolyai, R. P. Smith, and C. T. Gray), 1972. "Ascorbic Acid and Chemically Inducted Methemoglobins," in Toxicological Applied Pharmacology, Vol. 21, pp. 176-185.

Bopp et al. (B. A. Bopp, R. C. Sanders, and J. W. Kesterson), 1982. Drug Melab. Rev., Vol. 13, pp. 271-318.

Boyd, C. E., 1979. Water Quality in Warmwater Fish Ponds, Auburn University Agricultural Experiment Station, Auburn, Alabama.

Brater, C. D., 1992. "Treatment of Renal Disorders and the Influence of Renal Function on Drug Disposition," in Clinical Pharmacology, Vol. 31, pp. 776-785.

Buchet et al. (J. P. Buchet, R. Lauwerys, and H. Roels), 1990. "Renal Effects of Cadmium Body Burden of the General Population," in Lancet, Vol. 336, pp. 669-702.

Buchet et al. (J. P. Buchet, R. Lauwerys, and H. Roels), 1981. "Urinary Excretion of Inorganic Arsenic and its Metabolites After Repeated Ingestion of Sodium Metaarsenite by Volunteers," in International Archives of Occupational and Environmental Health, No. 48, pp. 111-118.

Buchet et al. (J. P. Buchet, H. Roels, and R. Lauwerys), 1980. "Repeated Surveillance of Exposure to Cadmium, Manganese, and Arsenic in School-Age Children Living in Rural, Urban, and Nonferrous Smelter Areas in Belgium," in Environmental Research, No. 22, pp. 95-108. 
Burton, G. A., Jr., 1991. "Assessing the Toxicity of Freshwater Sediments," in Environmental Toxicology and Chemistry, No. 10, pp. 1585-1627.

Byerrum et al. (R. U. Byerrum, R. E. Eckardt, L. L. Hopkins), 1974. Vanadium, National Academy of Sciences, Washington, D.C.

Byrne, A. R., and L. Kosta, 1978. Sci. Total Environ., Vol. 10, pp. 17-30.

Calabrese, E. J., and R. W. Tuthill, 1977. "Elevated Blood Pressure and High Radium Levels in the Public Drinking Water," in Archives of Environmental Health, September/October 1977, pp. 200-202.

Carson et al. (B. L. Carson, H. V. Ellis III, and J. L. McCann), 1986. Toxicology and Biological Monitoring of Metals in Humans, Lewis Publishers, Inc., New York, New York, pp. 226-230.

Casarett, L. J., and J. Doull, 1991. Toxicology: The Basic Science of Poisons, fourth edition, Macmillan Publishing Company, New York, New York.

$\mathrm{CDH}$ (Colorado Department of Health), 1991. Basic Standards and Methodologies for Surface Water, 3.1.0, Water Quality Control Commission, Denver, Colorado.

CDH (Colorado Department of Health), 1990. "Ground Water Quality Standards," 3.11.5A, The Basic Standard's for Ground Water, Water Quality Control Commission, Denver, Colorado.

Chapman, P. M., 1989. "Current Approaches to Developing Sediment Quality Criteria," Environmental Toxicology and Chemistry, No. 8, pp. 598-599.

Clark, D. R., 1987. "Selenium Accumulation in Mammals Exposed to Contaminated California Irrigation Drainwater," in The Science of the Total Environment, Vol. 66, pp. 147-168.

Clark et al. (D. R. Clark, P. A. Ogasawara, G. J. Smith, and H. M. Ohlendorf), 1989. "Selenium Accumulation by Raccoons Exposed to Irrigation Drainwater at Kesterson National Wildlife Refuge, California, 1986," in Arch. Environ. Toxicol., Vol. 19, pp. 787-794.

Cothern, C. R., and W. L. Lappenbusch, 1983. "Occurrence of Uranium in Drinking Water in the United States," in Health Physics, No. 45, pp. 89-99.

Crecelius, E. A., 1977. "Changes in the Chemical Speciation of Arsenic Following Ingestion by Man," in Environmental Health Perspective, No. 19, pp. 147-150.

Cummins, L. M., and E. T. Kimura, 1971. Toxicological Applied Pharmacology, Vol. 20, pp. 89-96. 
Curran et al. (G. L. Curran, D. L. Azarnoff, and R. E. Bolinger), 1959. Journal of Clinical Investigation, Vol. 38, pp. 1251-1261.

DuBowy, P. J., 1989. "Effects of Diet on Selenium Bioaccumulation in Marsh Birds," in Journal of Wildlife Management, Vol. 53, No. 3, pp. 776-781.

DHHS (U.S. Department of Health and Human Services), 1993a. Toxicological Profile for Arsenic, prepared by Life Systems, Inc., for Clement International Corporation.

DHHS (U.S. Department of Health and Human Services), 1993b. Toxicological Profile for Cadmium, U.S. Department of Health and Human Services, Atlanta, Georgia.

DHHS (U.S. Department of Health and Human Services), 1993c. Toxicolgical Profile for Lead, U.S. Department of Energy, Atlanta, Georgia.

DHHS (U.S. Department of Health and Human Services), 1992a. Toxicological Profile for. Antimony and Compounds, U.S. Department of Health and Human Services, Public Health Service, Agency for Toxic Substances and Disease Registry.

DHHS (U.S. Department of Health and Human Services), 1992b. Toxicological Profile for Manganese, U.S. Department of Health and Human Services, Atlanta, Georgia.

DHHS (U.S. Department of Health and Human Services), 1992c. Toxicological Profile for Lead, U.S. Department of Health and Human Services, Atlanta, Georgia.

DHHS (U.S. Department of Health and Human Services), 1989. Toxicological Profile for Selenium, U.S. Department of Health and Human Services, Atlanta, Georgia.

Dimond et al. (E. G. Dimond, J. Caravaca, and A. Benchimol), 1963. "Vanadium: Excretion, Toxicity, Lipid Effect in Man," in American Journal of Clinical Nutrition, Vol. 12, pp. 49-53.

Di Toro et al. (D. M. Di Toro, C. S. Zarba, D. J. Hansen, W. J. Berry, R. C. Swartz, C. E. Cowan, S. P. Pavlou, H. E. Allen, N. A. Thomas, and P. R. Paquin), 1991. "Technical Basis for Establishing Sediment Quality Criteria for Nonionic Organic Chemicals Using Equilibrium Partitioning," in Environmental Toxicology and Chemistry, No. 10, pp. 1541-1583.

DOC (U.S. Department of Commerce), 1991. Population and Housing, Summary of Population and Housing Characteristics, Colorado, July 1991, Bureau of the Census, U.S. Government Printing Office, Washington, D.C.

DOE (U.S. Department of Energy), 1994a. Programmatic Environmental Impact Statement for the Uranium Mill Tailings Remedial Action Ground Water Project, draft, DOE/EIS-0198, Rev. 3, April 1994, prepared by the U.S. Department of Energy, UMTRA Project Office, Albuquerque Operations Office, Albuquerque, New Mexico. 
DOE (U.S. Department of Energy), 1994b. Human Health Risk Assessment Methodology for the UMTRA Ground Water Project, DOE/AL/62350-170, Rev. 0, November 1994, U.S. Department of Energy, UMTRA Project Office, Albuquerque Operations Office, Albuquerque, New Mexico.

DOE (U.S. Department of Energy), 199:2a. Remedial Action Plan and Site Design for Stabilization of the Inactive Uranium Mill Tailings Sites at Rifle, Colorado, DOE/AL-050506.0000, February 1992, prepared by the U.S. Department of Energy, UMTRA Project Office, Albuquerque Operations Office, Albuquerque, New Mexico.

DOE (U.S. Department of Energy), 1992b. Baseline Risk Assessment for Groundwater and Surface Water Contamination at the Uranium Mill Tailings Sites in Rifle, Colorado, DOE/AL-050127.0000, July 1992, prepared by the U.S. Department of Energy, UMTRA Project Office, Albuquerque Operations Office, Albuquerque, New Mexico.

DOE (U.S. Department of Energy), 1990. Final Environmental Impact Statement for Remedial Actions at the Former Union Carbide Corporation Uranium Mill Sites, Rifle, Garfield County, Colorado, DOE/EIS-0132-F, March 1990, prepared by the U.S. Department of Energy, UMTRA Project Office, Albuquerque Operations Office, Albuquerque, New Mexico.

Eisler, R., 1989. Molybdenum Hazards to Fish, Wildlife, and Invertebrates: A Synoptic Review, Biological Report 85 (1.19), prepared by the Patuxent Wildlife Research Center, U.S. Fish and Wildlife Service, Laurel, Maryland, for the U.S. Department of the Interior.

Eisler, R., 1985. Cadmium Hazards to Fish, Wildlife, and Invertebrates: A Synoptic Review, Biological Report 85 (1.2), U.S. Fish and Wildlife Service, Patuxent Wildlife Research Center, Laurel, Maryland.

EPA (U.S. Environmental Protection Agency), 1994a. Integrated Risk Information System (IRIS), database, Office of Research and Development, Washington, D.C.

EPA (U.S. Environmental Protection Agency), 1994b. Health Effects Assessment Summary Tables (HEAST), 9200.6-303 (94-1), annual update, March 1994, Office of Solid Waste and Emergency Response, Washington, D.C.

EPA (U.S. Environmental Protection Agency), 1992a. Dermal Exposure Assessment: Principles and Applications, EPA/600/8-91/011B, prepared for the U.S. Environmental Protection Agency, Washington, D.C.

EPA (U.S. Environmental Protection Agency), 1992b. "Developing a Work Scope for Ecological Assessment," in Eco Update, intermittent bulletin, Vol. 1, No. 4, U.S. Environmental Protection Agency, Office of Emergency and Remedial Response, Hazardous Site Evaluation Division, Washington, D.C. 
EPA (U.S. Environmental Protection Agency), 1992c. Drinking Water Criteria Document for Sulfate, final, Health and Environmental Criteria Division, Office of Science and Technology, U.S. Environmental Protection Agency.

EPA (U.S. Environmental Protection Agency), 1992d. Toxic Substance Spreadsheet, Region IV, U.S. Environmental Protection Agency, Atlanta, Georgia.

EPA (U.S. Environmental Protection Agency), 1991. Water Quality Criteria Summary, May 1991, Office of Science and Technology, Health and Ecological Criteria Division, Ecological Risk Assessment Branch, Human Risk Branch, Washington, D.C.

EPA (U.S. Environmental Protection Agency), 1989a. Risk Assessment Guidance for Superfund, Vol. II, Environmental Evaluation Manual, EPA/540/1-89/001, Office of Emergency and Remedial Response, Washington, D.C.

EPA (U.S. Environmental Protection Agency), 1989b. Risk Assessment Guidance for Superfund, Volume l, Human Health Evaluation Manual, EPA/540/1-89/002, Office of Emergency and Remedial Response, Washington, D.C.

EPA (U.S. Environmental Protection Agency), 1989c. Drinking Water Criteria Document for Uranium, external review draft, Criteria and Standards Division, Office of Drinking Water, Washington, D.C.

EPA (U.S. Environmental Protection Agency), 1988. Interim Sediment Quality Criteria Values for Nonpolar Hydrophobic Organic Contaminants, Office of Water Regulations and Standards, Washington, D.C.

EPA (U.S. Environmental Protection Agency), 1987. Health Effects Assessment for Vanadium and Compounds, July 1987, U.S. Environmental Protection Agency, Environmental Criteria and Assessment Office, Cincinnati, Ohio.

EPA (U.S. Environmental Protection Agency), 1986. Quality Criteria for Water, EPA 440/5-86-001, Office of Regulations and Standards, Washington, DC.

EPA (U.S. Environmental Protection Agency), 1984. Health Assessment Document: Inorganic Arsenic, U.S. Environmental Protection Agency, Washington, D.C.

EPA (U.S. Environmental Protection Agency), 1980. Ambient Water Quality Criteria for Selenium, EPA 440/5-80-070, NTIS PB 81-117814, prepared by the Office of Health and Environmental Assessment, Environmental Criteria and Assessment Office, Cincinnati, Ohio, for the Office of Water Quality Planning Standards, Washington, D.C.

'SPA (U.S. Environmental Protection Agency), 1977. Scientific and Technical Assessment Report on Vanadium, EPA-600-6-77-002, U.S. Environmental Protection Agency, Washington, DC. 
EPA (U.S. Environmental Protection Agency), 1973. Water Quality Criteria 1972, PB-236 199, National Academy of Sciences, Washington, D.C.

Evans, A. M., 1987. An Introduction to Ore Geology, Blackwell Scientific Publications, Boston, Massachusetts.

Ferm, V. H., 1971. "The Teratogenic Profile of Sodium Arsenate in the Golden Hamster," in Archives of Environmental Health, No. 22, pp. 557-560.

Fisenne et al. (I. M. Fisenne, P. M. Perry, and N. H. Harley), 1988. "Uranium in Humans," in Radiation Protection Dosinetry, No. 24, pp. 127-131.

Flanagan et al. (P. R. Flanagan, J. S. McLellan, J. Haist, M. G. Cherian, M. J. Chamberlain, and L. S. Valbergl, 1978. Gastroenterology, Vol. 74, pp. 841-846.

Foulkes, E. C., 1990. "The Concept of Critical Levels of Toxic Heavy Metals in Target Tissues," in Toxicology, Vol. 20, No. 5, pp. 327-339.

Freis, E. D., 1976. "Salt, Volume and the Prevention of Hypertension," in Circulation, Vol. 53, No. 4, pp. 589-595.

Friberg et al. (L. Friberg, G. F. Nordberg, and V. B. Vouk), 1986. Handbook on the Toxicology of Metals, Volume II: Specific Metals, second edition, Elsevier, New York, New York.

Gilman et al. (A. G. Gilman, T. Rall, A. Nies, P. Taylor), 1990. The Pharmacological Basis of Therapeutics, eighth edition, Pergamon Press, New York, New York.

Gosselin et al. (R. E. Gosselin, H. C. Hodge, and R. P. Smith), 1976. Clinical Toxicology of Commercial Products, fourth edition, Williams and Wilkins, Baltimore, Maryland.

Greensmith et al. (J. T. Greensmith, F. H. Hatch, R. H. Rastall), 1971. Petrology of the Sedimentary Rocks, Thomas Murby \& Company, London, England.

Hadjimarkos, D. M., 1968. Adv. Oral Biol., Vol. 3, pp. 253-292.

Hadjimarkos, D. M., 1966. Nature, Vol. 209, pp. 1137.

Hammerson, G. A., 1986. Amphibians and Reptiles in Colorado, Colorado Division of Wildlife, Denver, Colorado.

Harris et al. (W. R. Harris, S. B. Friedman, and D. Silberman), 1984. Journal of Inorganic Biochemistry, Vol. 20, pp. 157-169.

Heard, M. J., and H. C. Chamberlain, 1982. "Effect of Minerals and Food on Uptake of Lead From the Gastrointestinal Tract in Humans," in Human Toxicology, Vol. 1, pp. 441-445. 
Hood, R. D., 1972. "Effects of Sodium Arsenite on Fetal Development," in Bulletin of Environmental Contamination and Toxicology, No. 7, p. 216.

IARC (International Agency for Research on Cancer), 1987. IARC Monographs on the Evaluation of the Carcinogenic Risk of Chemicals to Humans, Supplement 7.

ICRP (International Commission on Radiological Protection), 1960. ICRP Publ., 2.

Josephs, H. W., 1958. "Absorption of Iron as a Problem in Human Physiology," in Blood, No. 13, pp. 1-54.

Kamm et al. (L. Kamm, G. G. McKeown, and D. M. Smith), 1965. "New Colorimetric Method for the Determination of Nitrate and Nitrite Content in Baby Foods," in J. Assoc. Office Agr. Chemists, Vol. 48, p. 892.

Khattak, R. A., and W. M. Jarrell, 1989. "Effect of Saline Irrigation Waters on Soil Manganese Leaching and Bioavailability to Sugar Beets," in Soil Sci. Soc. Am. J., Vol. 53, pp. 142-146.

Kjellström, T., 1979. Environmental Health Perspective, Vol. 28, pp. 169-197.

Kondakis et al. (X. G. Kondakis, N. Makris, M. Leotsinidis, M. Prinou, and T. Papapetropoulos), 1989. "Possible Health Effects of High Manganese Concentration in Drinking Water," in Archives of Environmental Health, Vol. 44, No. 3, pp. 175-178.

Leach et al. (L. J. Leach, R. M. Gelein, B. J. Panner, C. L. Ylie, and C. C. Cox), 1984. The Acute Toxicity of the Hydrolysis Products of Uranium Hexafluoride (UF6) When Inhaled by the Rat and Guinea Pig, final report, ISS K/SUB-81-9039-3, NTIS DE84011539.

Lee, D. H. K., 1970. "Nitrates, Nitrites, and Methemolglobinemia," in Environmental Research, Vol. 3, pp. 484-511.

Lemly, A. D., and G. J. Smith, 1987. "Aquatic Cycling of Selenium: Implications for Fish and Wildlife," Fish and Wildlife Leaflet 12, U.S. Fish and Wildlife Service, Washington D.C.

Levenworth, L., 1994. City of Rifle attorney, personal communication to M. Gawthrop, Jacobs Engineering Group Inc., UPDCC File Location No. 6.19.7, Albuquerque, New Mexico, 15 November 1994.

Lindgren et al. (A. Lindgren, M. Vahter, and L. Dencker), 1982. "Autoradiographic Studies on the Distribution of Arsenic in Mice and Hamsters Administered ${ }^{74}$ As-arsenite or -arsenate," in Acta Pharmacology and Toxicology, No. 51, pp. 253-265. 
Lönnerdal et al. (B. Lönnerdal, C. L. Keen, J. G. Bell, and B. Sandstrom), 1987.

"Manganese Uptake and Retention," in Nutritional Bioavailability of Manganese,

C. Kies, ed., American Chemical Society Symposium Series 354, Washington,

D.C., pp. 9-20.

Maheshwari et al. (U. R. Maheshwari, J. T. McDonald, V. S. Schneider, A. J. Brunetti, L. L. Leybin, E. Newburn, and H. C. Hodge), 1981. "Fluoride Balance Studies in Ambulatory Healthy Men With and Without Fluoride Supplements," American Journal of Chemical Nutrition, December 1981, Vol. 34, pp. 2679-2684.

Marafante, E., and M. Vahter, 1987. "Solubility, Retentions and Metabolism of Intratracheally and Orally Adininistered Inorganic Arsenic Compounds in Hamsters," in Environmental Research, No. 42, pp. 72-82.

Marcus, W. L., and A. S. Rispin, 1988. "Threshold Carcinogenicity Using Arsenic as an Example," in Advances in Environmental Toxicology, Vol. XV, Risk Assessment and Risk Management of Industrial and Environmental Chemicals, C. R. Còthern, M. A. Mehlman, and W. L. Mlarcus, eds., Princeton Scientific Publishing Co., New Jersey, pp. 133-159.

Markos, G., and K. J. Bush, 1983. Data for the Geochemical Investigation of UMTRAP Designated Sites at Rifle Colorado, UMTRA-DOE/AL-0238, September 1983, prepared by Geochemistry and Environmental Chemistry Research, Inc., Rapid City, South Dakota.

Marshall, J., 1995. Jacobs Engineering Group Inc., personal communication to T. Monks, Jacobs Engineering Group Inc., UPDCC File Location No. 6.19.7, Albuquerque, New Mexico, 17 March 1995.

Maynard, E. A., and H. C. Hodge, 1949. "Study of Toxicity of Various Uranium Compounds When Fed to Experimental Animals," in Pharmacology and Toxicology of Uranium Compounds, C. Voegtlin and H. C. Hodge, eds., National Nuclear Energy Services, Div. VI, McGraw Hill, New York, New York, Vol. 1, pp. 309-376.

Medinsky et al. (M. A. Medinsky, R. G. Cuddihy, and R. O. McClellan), 1981. J. Toxicol. Environ. Health, Vol. 8, pp. 917-928.

Mena et al. (I. Mena, K. Horiuchi, K. Burke, and G. C. Cotzias), 1969. "Chronic Manganese Poisoning: Individual Susceptibility and Absorption of Iron," in Neurology, No. 19, pp. 1000-1006.

Meneely, G. R., and H. D. Battarbee, 1976. "Sodium and Potassium," in Nutrition Reviews, No. 8, pp. 225-235.

Merritt, R. C., 1971. The Extractive Metallurgy of Uranium, Colorado School of Mines Research Institute, Golden, Colorado, 1971. 
Millar et al. (K. R. Millar, M. A. Gardiner, and A. D. Sheppard), 1973. New Zealand Journal of Agricultural Research, Vol. 16, pp. 115-127.

Morrison et al. (G. M. P. Morrison, G. E. Batley, and T. M. Florence), 1989. "Metal Speciation and Toxicity," in Chem. Br., No. 25, p. 791.

NAS (National Academy of Sciences), 1972. "Airborne Lead in Perspective: Biologic Effects of Atmospheric Pollutants," in Lead, National Academy of Sciences, Washington, D.C., pp. 71-177 and pp. 281-313.

National Research Council, 1989. Recommended Dietary Allowances, tenth edition, National Academy Press, Washington, D.C.

National Research Council, 1980. Drinking Water and Health, Vol. 3, Safe Drinking Water Committee.

National Research Council, 1973. Medical and Biological Effects of Environmental Pollutants: Manganese, Committee on Biological Effects of Atmospheric Pollutants, Division of Medical Sciences.

NCRP (National Council on Radiation Protection and Measurements), 1984. Exposures From the Uranium Series With Emphasis on Radon and Its Daughter, NCRP Report No. 77, Bethesda, Maryland.

Nichols, D. G., and A. T. Scholz, 1989. "Concentrations of Cadmium, Strontium, and Uranium in Fish and Water Samples Collected From a Small Stream Receiving Uranium Mine Discharge," in Journal of Freshwater Ecology, No. 5(1), pp. 1325.

NOAA (National Oceanic and Atmospheric Administration), 1990. "The Potential for Biological Effects of Sediment-Sorbed Contaminants Tested in the National Status and Trends Program," NOAA technical memo, NOS OMA 52.

Nordberg et al. (G. F. Nordberg, T. Kjellström, and M. Nordberg), 1985. Cadmium and Health: a Toxicological and Epidemiological Appraisal, L. Friberg, C. G. Elinder, T. Kjellström, and G. F. Nordberg, eds., CRC Press, Boca Raton, Florida.

Ohlendorf, H. M., 1989. "Bioaccumulation and Effects of Selenium in Wildlife," in Selenium in Agriculture and the Environment, Special Publication No. 23, Soil Science Society of America, Madison, Wisconsin.

Opresko et al. (D. M. Opresko, B. E. Sample, and G. W. Suter II), 1994. Toxicological Benchmarks for Wildlife, 1994 revision, ES/ER/TM-86/R1, Oak Ridge National Laboratory, Oak Ridge, Tennessee. 
Parkhurst et al. (D. L. Parkhurst, D. C. Thorstenson, and D. N. Plummer), 1980.

PHREEQE - A Computer Program for Geochemical Calculations, U. S. Geological Survey, Water Resources Investigation 8-096, National Technical Information Services Report PB81-167-801, Springfield, Virginia.

Pennington, J. A., and J. W. Jones, 1987. "Molybdenum, Nickel, Cobalt, Vanadium, and Strontium in Total Diets," in Journal of the American Dietetic Association, December 1987, Vol. 87, No. 12.

Perry et al. (H. M. Perry, Jr., S. Teitlebaum, and P. L. Schwartz), 1955. Fed. Proc., Vol. 14, pp. 113-114.

Pershagen, G., and M. Vahter, 1979. Arsenic, Swedish Environmental Protection Board, Stockholm, Sweden.

Prister, B. S., 1969. GKIAE Report by Atomizdat, Moscow (Canadian translation AEC/TR/7178 (1970), and USCEAR Rep. A/AC.82/G/L 1298).

Proescher et al. (F. Proescher, H. A. Seil, and A. W. Stillians), 1917. Am. J. Syph., Vol. 1, pp. 347-405.

Rai, D., and J. M. Zachara, 1984. Chemical Attenuation Rates, Coefficients, and Constants in Leachate Migration, Volume 1: A Critical Review, EPRI, EA-3356, Vol. 1, Research Project 2188-1.

Robinson et al. (M. F. Robinson, J. M. McKenzie, C. Thomson, and A. L. Van Rijn), 1973. British Journal of Nutrition, Vol. 30, pp. 195-205.

Roseberry, A. M., and D. E. Burmaster, 1992. "Lognormal Distributions for Water Intake by Children and Adults," in Risk Analysis, Vol. 12, No. 1, pp. 99-104.

Rosenfeld, I., and O. A. Beath, 1964. Selenium, Geobotany, Biochemistry, Toxicity, and Nutrition, Academic Press, New York, New York.

Rosoff, B., and H. Spencer, 1964. Nature (London), Vol. 202, pp. 410-411.

Schroeder et al. (H. A. Schroeder, J. J. Balassa, and I. H. Tipton), 1963. Journal of Chronic Diseases, Vol. 16, pp. 1047-1071.

Shannon, R. L., and D. S. Strayer, 1989. "Arsenic-Induced Skin Toxicity," in Human Toxicology, No. 8, pp. 99-104.

Shea, D., 1988. "Developing National Sediment Quality Criteria," in Environmental and Scientific Technology, No. 22(11), pp. 1256-1261.

Sims, J. T., 1986. "Soil pH Effects on the Distribution and Plant Availability of Manganese, Copper, and Zinc," in Soil Sci. Soc. Am. J., Vol. 50, pp. 367-373. 
Sinnock, S., 1981. "Glacial Moraines, Terrace, and Pediments of Grand Valley, Colorado in Western Slope Colorado," R. C. Epis and J. F. Callendar, eds., New Mexico Geological Society, 32nd Field Conference Guidebook, pp. 113-120.

Smith, G. E., 1966. "Causes of Nitrate Accumulation in Plants and Water Supplies," paper to 18th Annual Midwest Fertilizer Conference, Chicago, Illinois.

Smith et al. (D. P. Smith, J. H. Kennedy, and K. L. Dickson), 1991. "An Evaluation of a Naidid Oligochaete as a Toxicity Test Organism," in Environmental Toxicology and Chemistry, Vol. 10, pp. 1459-1465.

Snyder, F., and W. E. Cornatzer, 1958. Nature, Vol. 182, pp. 462.

Somerville, J., and B. Davies, 1962. Am. Health J., Vol. 54, pp. 54-56.

Stevens et al. (W. F. Stevens, W. Bruenger, D. R. Atherton, J. M. Smith, and G. N. Taylor), 1980. "The Distribution and Retention of Hexavalent ${ }^{233} \mathrm{U}$ in the Beagle," in Radiation Research, No. 83, pp. 109-126.

Sullivan et al. (M. F. Sullivan, P. S. Ruemmler, J. L. Ryan, and R. L. Bushhom), 1986. "Influence of Oxidizing or Reducing Agents on Gastrointestinal Absorption of $U$, Pu, Am, Cm, and Pm by Rats," in Health Physics, No. 50, pp. 223-232.

Summerskill, W. H. H., and E. Wolpert, 1970. "Ammonia Metabolism in the Gut," in American Journal of Clinical Nutrition, Vol. 23, pp. 633-639.

SWPCB (State Water Pollution Control Board), 1952. State of California Water Quality Criteria, State Water Pollution Control Board, Sacramento, California.

TAC (Technical Assistance Contractor), in preparation. Supplement to the baseline risk assessment of ground water contamination at the uranium mill tailings sites near Rifle, Colorado.

TAC (Technical Assistance Contractor), 1994. Unpublished field notes, Rifle, Colorado UMTRA Project site, unpublished report prepared by the Technical Assistance Contractor, Albuquerque, New Mexico, for the U.S. Department of Energy, UMTRA Project Office, Albuquerque Operations Office, Albuquerque, New Mexico.

Tank, G., and C. A. Storvick, 1960. Journal of Dental Research, Vol. 39, pp. 473-488.

Tipton et al. (I. H. Tipton, P. L. Stewart, and J. Dickson), 1969. Health Physics, Vol. 9, pp. 103-145.

Tracy et al. (B. L. Tracy, J. M. Quinn, J. Lahey, A. P. Gilman, K. Mancuso, A. P. Yagdinas, and D. C. Villeneuve), 1992. "Absorption and Retention of Uranium from Drinking Water by Rats and Rabbits," in Health Physics, Vol. 62, pp. 65-73. 
Tseng, W. P., 1977. "Effects and Dose-Response Relationship of Skin Cancer and Blackfoot Disease with Arsenic," in Environmental Health Perspectives, No. 19, pp. 109-119.

USACE (U.S. Army Corp of Engineers), 1992. Department of the Army Permit 190110228, U.S. Army Engineer District, Corps of Engineers, Sacramento, California.

USGS (U.S. Geological Survey), 1984. Element Concentrations in Soils and Other Surficial Materials of the Conterminous United States, H. T. Shocklett and J. G. Boerngen, USGS Professional Paper No. 1270, U.S. Government Printing Office, Washington, D.C.

Van Velzen, W. T., 1980. "Forty-Third Breeding Bird Census," American Birds, Vol. 34, No. 1, pp. 41-106.

Van Zinderen Bakker and J. F. Jaworski, 1980. Effects of Vanadium in the Canadian Environment, Ottawa, Canada: National Research Council Canada, Associate Committee Scientific Criteria for Environmental Quality.

Venugopal, B., and T. D. Luckey, 1978. "Chemical Toxicity of Metals and Metalloids," in Metal Toxicity in Mammals, Plenum Press, New York, New York.

Webb, J. L., 1966. Enzymes and Metabolic Inhibitors, Academic Press, New York, New York.

Weigel, F., 1983. "Uranium and Uranium Compounds," in Kirk-Othmer Encyclopedia of Chemical Technology, third edition, M. Grayson, ed., John Wiley and Sons, New York, New York, Vol. 23, pp. 502-547.

Whitney et al. (E. N. Whitney, E. M. Hamilton, and S. R. Roth), 1990. Understanding Nutrition, fifth edition, West Publishing Company, St. Louis, Missouri.

WHO (World Health Organization), 1988. Vanadium, Environmental Health Criteria 81, published under the joint sponsorship of the United Nations Environment Programme, the International Labour Organisation, and the World Health Organization, Geneva, Switzırland.

WHO (World Health Organization), 1981. Arsenic, Environmental Health Criteria 18, published under the joint sponsorship of the United Nations Environment Programme, the International Labour Organisation, and the World Health Organization, Geneva, Switzerland.

WHO (World Health Organization), 1977. Lead, Environmental Health Criteria 3, published under the joint sponsorship of the United Nations Environment Programme, the International Labour Organisation, and the World Health Organization, Geneva, Switzerland. 
Will, M. E., and G. W. Suter II, 1994. Toxicological benchmarks for screening potential contaminants of concern for effects on terrestrial plants: 1994 revision, TN ES/ER/TM-85/R1, Oak Ridge National Laboratory, Oak Ridge, Tennessee.

Wrenn et al. (M. E. Wrenn, P. W. Durbin, B. Howard, J. Lipsztein, J. Rundo, E. T. Still, and D. L. Willis), 1985. "Metabolism of Ingested $U$ and Ra," in Health Physics, No. 48, pp. 601-633.

Yakawa, M., and M. Suzuki-Yasumoto, 1980. Archives of Environmental Health, Vol. 35, pp. 36-44.

Yang et al. (G. Yang, R. Zhou, and S. Yin), 1989a. "Studies of Safe Maximal Daily Dietary Selenium Intake in a Seleniferous Area in China," I, in J. Trace Elem. Electrolytes Health Dis., Vol. 3(2), pp. 77-87.

Yang et al. (G. S. Yang, R. Zhou, and S. Yin), 1989b. "Studies of Safe Maximal Daily Dietary Selenium Intake in a Seleniferous Area in China, II, Relation Between Selenium Intake and the Manifestation of Clinical Signs and Certain Biochemical Alterations in Blood and Urine," in J. Trace Elem. Electrolytes Health Dis., Vol. 3(2), pp. 123-130.

\section{CODE OF FEDERAL REGULATIONS}

40 CFR Part 192, Health and Environmental Protection Standards for Uranium and Thorium Mill Tailings, U.S. Environmental Protection Agency (1994).

40 CFR Part 264, Standards for Owners and Operators of Hazardous Waste Treatment, Storage, and Disposal Facilities, U.S. Environmental Protection Agency (1994).

\section{FEDERAL REGISTER}

55 FR 8866, National Oil and Hazardous Substances Pollution Contingency Plan; Final Rule, U.S. Environmental Protection Agency, 8 March 1990.

60 FR 2854, Groundwater Standards for Remedial Actions at Inactive Uranium Processing Sites, final rule, U.S. Environmental Protection Agency, 11 January 1995.

\section{UNITED STATES CODE}

42 USC $\$ 7901$ et seq., Uranium Mill Tailings Radiation Control Act, 8 November 1978. 